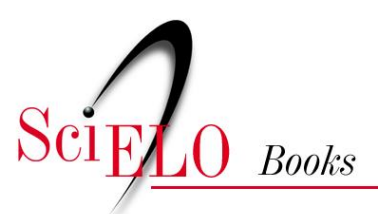

\title{
A lógica da internação \\ instituições totais e disciplinares (des)educativas
}

Silvio José Benelli

BENELLI, SJ. A lógica da internação: instituições totais e disciplinares (des)educativas [online]. São Paulo: Editora UNESP, 2014, 252 p. ISBN 978-85-68334-44-7. Available from SciELO Books $<\underline{\text { http://books.scielo.org }>\text {. }}$

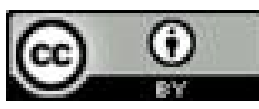

All the contents of this work, except where otherwise noted, is licensed under a Creative Commons Attribution 4.0 International license.

Todo o conteúdo deste trabalho, exceto quando houver ressalva, é publicado sob a licença Creative Commons Atribição $\underline{4.0}$.

Todo el contenido de esta obra, excepto donde se indique lo contrario, está bajo licencia de la licencia Creative Commons Reconocimento 4.0. 


\section{A LÓGICA DA INTERNAÇÃO}




\title{
FUNDAÇÃO EDITORA DA UNESP
}

\author{
Presidente do Conselho Curador \\ Mário Sérgio Vasconcelos \\ Diretor-Presidente \\ José Castilho Marques Neto \\ Editor-Executivo \\ Jézio Hernani Bomfim Gutierre
}

Superintendente Administrativo e Financeiro

William de Souza Agostinho

Assessores Editoriais

João Luís Ceccantini

Maria Candida Soares Del Masso

Conselho Editorial Acadêmico

Áureo Busetto

Carlos Magno Castelo Branco Fortaleza

Elisabete Maniglia

Henrique Nunes de Oliveira

João Francisco Galera Monico

José Leonardo do Nascimento

Lourenço Chacon Jurado Filho

Maria de Lourdes Ortiz Gandini Baldan

Paula da Cruz Landim

Rogério Rosenfeld

Editores-Assistentes

Anderson Nobara

Jorge Pereira Filho

Leandro Rodrigues 


\section{SILVIO JOSÉ BENELLI}

\section{A lógica \\ DA INTERNAÇÃO \\ INSTITUIÇÕES TOTAIS \\ E DISCIPLINARES \\ (DES)EDUCATIVAS}


Direitos de publicação reservados à:

Fundação Editora da Unesp (FEU)

Praça da Sé, 108

01001-900 - São Paulo - SP

Tel.: (0xx11) 3242-7171

Fax: (0xx11) 3242-7172

www.editoraunesp.com.br

www.livrariaunesp.com.br

feu@editora.unesp.br

CIP - BRASIL. Catalogação na publicação

Sindicato Nacional dos Editores de Livros, RJ

B398L

Benelli, Silvio José

A lógica da internação: instituições totais e disciplinares (des)educa-

tivas / Silvio José Benelli. São Paulo: Editora Unesp Digital, 2014.

Recurso digital

Formato: ePDF

Requisitos do sistema: Adobe Acrobat Reader

Modo de acesso: World Wide Web

ISBN 978-85-68334-44-7 (recurso eletrônico)

1. Saúde mental - Brasil. 2. Política de saúde mental - Brasil.

3. Psicologia clínica. 4. Psiquiatria. 5. Livros eletrônicos. I. Título.

$15-20358$

CDD: 362.2

CDU: 364.622

Este livro é publicado pelo projeto Edição de Textos de Docentes e

Pós-Graduados da UNESP - Pró-Reitoria de Pós-Graduação da UNESP (PROPG) / Fundação Editora da Unesp (FEU)

Editora afiliada:

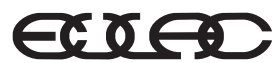

Asociación de Editoriales Universitarias de América Latina y el Caribe

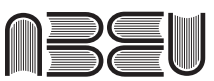

Associação Brasileira de Editoras Universitárias 


\section{SUMÁRIO}

\section{Apresentação 7}

1 O lugar das instituições disciplinares na sociedade contemporânea 13

2 Goffman e as instituições totais em análise 23

3 Foucault e a prisão como modelo institucional da sociedade disciplinar 63

4 Goffman e Foucault: semelhanças e diferenças 85

5 Estudos de casos singulares sobre estabelecimentos totais e disciplinares 91

6 Atravessamentos institucionais: o hospital geral, o hospital psiquiátrico, a prisão e o internato escolar 221

Conclusão - Efeitos éticos da internação como estratégia institucional 235

Referências 243 


\section{ApresentaÇão}

Este livro surgiu a partir do nosso encontro com as obras de Goffman (1987) e de Foucault (1999b), experiência que deflagrou um processo de intensa produção de pesquisas e de publicações, que agora reunimos em livro. Vamos tratar do tema das instituições totais e disciplinares e dos processos de subjetivação que elas promovem em sua dinâmica de funcionamento.

Há muito que discutir sobre o tema das instituições que funcionam em regime de internato enquanto um fenômeno coletivo e as produções e equipamentos por elas estabelecidos no meio social. Entendemos que estabelecimentos que funcionam em regime de internato, como uma casa de formação, de educação, de ressocialização de pessoas, podem ser considerados uma instituição ${ }^{1}$ total (Goffman, 1987) e também disciplinar (Foucault, 1999b).

Acreditamos que esse espaço social específico merece ser devidamente investigado e seus procedimentos formativos específicos devem ser conhecidos e explicitados. Nesse sentido, estamos interessados em desvelar uma certa composição lógica que organizaria

1 No cotidiano e na linguagem corrente, é comum confundir a "instituição" com seus "estabelecimentos", usando um termo no lugar dou outro, mas a Análise Institucional (Baremblitt, 1998) nos permite distinguir, clara e rigorosamente, os conceitos para além de sua acepção coloquial. 
a existência e o modo de funcionamento das instituições de internação, bem como verificar os efeitos éticos que produzem.

De acordo com Goffman (1987), um estudo profundo do funcionamento institucional e dos diversos fenômenos que se produzem nesse espaço social específico pode proporcionar indícios valiosos quanto aos procedimentos utilizados na formação de pessoas. Seria possível entender como elas produzem a subjetividade daqueles que a compõe, tanto a dos internados quanto a dos dirigentes.

Quanto mais preciso for nosso conhecimento sobre a subjetividade institucional, o desenvolvimento psíquico que se processa em seu interior, as variáveis internas que a inibem e propiciam e também apreendermos as influências externas favorecedoras, dificultadoras, desviadoras ou deformadoras, tanto melhor saberemos como e onde centrar nossos possíveis esforços teórico-técnicos e éticos.

Tal trabalho poderia fornecer, indiretamente, algumas pistas de orientação para o desenvolvimento de perspectivas de atuação mais adequadas e eficazes para o profissional da área de saúde mental pública, objetivando uma contribuição aos serviços prestados à população. Ir ao encontro da subjetividade institucional do internado em seu contexto é uma tentativa de produzir uma pesquisa mais próxima da realidade social brasileira que possa vir a contribuir com um saber mais específico sobre a subjetividade no contexto brasileiro.

Neste livro reunimos alguns estudos publicados originalmente, como artigos em revistas de Psicologia, nos quais abordamos o modo de funcionamento das instituições totais e disciplinares. Procuramos realizar uma abordagem problematizadora de alguns estabelecimentos que adotam o regime de internato como estratégia pedagógica e ressocializadora. A condição de internado, num hospital geral, num hospital psiquiátrico, numa prisão, num colégio interno, num estabelecimento institucional ressocializador, num convento ou num seminário, parece-nos relevante em si mesma como um assunto que merece ser melhor estudado e compreendido (Guirado, 1987; Benelli, 2006, 2007). A estratégia da internação visando distintos objetivos continua bastante presente em nossa sociedade atual. 
Considerando a permanência temporal de tais instituições, certamente espécimes ultrapassados, sobreviventes de séculos anteriores, entendemos que Goffman (1987) e Foucault (1999b) são dois referenciais estratégicos fundamentais para um estudo e compreensão adequada dessas instituições (Benelli, 2004a). Elas ainda tendem a funcionar de modo clássico, tal como foram mapeadas por Goffman (1987) e Foucault (1999b), permanecendo alheias a sofisticações tecnológicas ou, em muitos casos, incorporando novidades da informática sem maiores transformações estruturais. Esse instrumental teórico possibilita ainda uma intervenção profissional crítica nessas instituições, permitindo-nos um posicionamento ético congruente com a lógica da produção de subjetividade singularizada, ao ocuparmos as brechas disponíveis na conjuntura atual.

De acordo com Goffman (1987, p.22), uma instituição total pode ser considerada um híbrido social, constituído parcialmente como grupo residencial e também como organização formal. Ela é um viveiro ou uma estufa que funciona como instrumento para modelar, mudar e transformar pessoas. Cada instituição total é, assim, um experimento natural do que se pode fazer com a identidade de um indivíduo. É aí que reside seu interesse para a Psicologia Social, que se ocupa com o estudo da subjetividade e Saúde Coletiva.

Como psicólogos interessados nos processos sociais e institucionais de produção de subjetividade, podemos nos perguntar: quais fatores realmente fazem os estabelecimentos institucionais de internação serem autodenominados educacionais, formativos, ressocializadores, punitivos, reabilitadores e terapêuticos? Quais são as teorias que norteiam seu funcionamento efetivo? Serão as teorias das Ciências Humanas, saberes oriundos da Pedagogia, da Educação, do Poder Judiciário, da Psicologia, da Psiquiatria e da Medicina? Autores como Goffman (1987) e Foucault (1999b) apresentam perspectivas paradoxais quanto a essas questões.

No Capítulo 1, discutimos e interrogamos o lugar que ocupam as instituições totais e disciplinares na sociedade contemporânea. Partimos da hipótese de que Goffman e Foucault explicitam a for- 
mação da ordem social burguesa, que se constituiu na Modernidade como uma ordem eminentemente disciplinar.

No Capítulo 2, apresentamos uma síntese do pensamento de Goffman (1987) sobre as instituições totais, procurando explicitar sua dinâmica de funcionamento e descrevendo suas peculiaridades.

No Capítulo 3, estudamos a perspectiva de Foucault (1999b) relativa aos fenômenos psicossociais que se produzem nas instituições totais e disciplinares, estabelecendo pontos de contato entre suas análises e as de Goffman (1987).

No Capítulo 4, apresentamos algumas semelhanças e diferenças entre os dois autores em estudo, Goffman e Foucault.

No Capítulo 5, realizamos alguns estudos de casos singulares com base na literatura, procurando desenvolver um exercício de análise institucional do estabelecimento internato escolar. $\mathrm{O}$ instrumental de análise utilizado baseia-se na teoria de Goffman (1987) sobre as "instituições totais" e nos estudos de Foucault (1999b) sobre a tecnologia disciplinar. Tomamos como material de estudo o romance O Ateneu, de Raul Pompéia, escrito em 1888, e apresentamos inicialmente o colégio interno como dispositivo produtor de subjetividade, descrevendo sua estrutura e dinâmica de funcionamento e, em seguida, acompanhamos a carreira moral do personagem central do livro. Também analisamos uma obra de Robert Musil (1880-1942), publicada em 1906, intitulada O jovem Törless, baseada em suas experiências num internato escolar. Finalizamos esse capítulo estudando um movimento religioso católico de matiz predominantemente totalitário, demonstrando que a estratégia do enclaustramento e a parafernália institucional totalitária continuam sendo utilizadas também no contexto religioso contemporâneo. Aí encontramos alguns dos casos exemplares que podem ser muito instrutivos e desveladores do modo de funcionamento das instituições totalitárias e disciplinares. Mais do que simplesmente enumerar "traços" ou "contornos" de um certo conjunto de estabelecimentos totais e disciplinares, visando uma certa "generalização" exemplificadora, nossa ambição é apreender sua configuração paradigmática singular. 
Apesar de tais estudos parecerem um pouco heterogêneos, pois analisamos duas obras literárias (uma datada do final do século XIX e outra do começo do século XX), além de um relato sobre o processo institucional de formação num movimento religioso católico contemporâneo, o que nos permite tratá-los como casos dignos de exame é o fato de que todos eles funcionam a partir da lógica típica de uma instituição de internação. Os três exemplos revelam com clareza os mecanismos institucionais de internação, em seus aspectos totais e disciplinares. E parece ser muito interessante que, embora os atores institucionais não calculem os efeitos das práticas institucionais que implementam, eles o fazem com maestria. Ou mais simplesmente, os dirigentes de tais estabelecimentos não conheceram as teorias de Goffman e de Foucault, mas construíram suas estratégias de internação a partir das possibilidades paradigmáticas e tecnológicas disponíveis no estrato social e histórico em que viviam e atuavam, produzindo realidades institucionais bastante específicas.

Um recorte de análise como esse certamente tem seus limites, pois nos baseamos em documentos: textos literários e o relato de um entrevistado sobre o movimento religioso do qual fez parte. Uma perspectiva científica positivista estreita talvez não possa conceber que a literatura contenha dados suficientemente objetivos e fidedignos que nos permitam conhecer a realidade de instituições sociais enquanto fatos históricos concretos. Mas não é esse o lugar teórico no qual nos situamos (Benelli, 2006, 2007). Para uma perspectiva institucionalista, isso é perfeitamente plausível.

Quanto ao movimento religioso contemporâneo, advertimos o leitor de que os dados que tomamos como base para nossa análise foram apresentados por alguém que se indispõe com o movimento, questionando seus princípios, métodos e efeitos e isso é o esperado, caso contrário poderíamos não ter relato algum. Perguntamo-nos como poderia ser a descrição do Movimento dos Focolares realizada por alguém que conseguiu aderir a ele sem maiores questionamentos. Pensamos que isso talvez introduzisse variações nos dados, mas não deixaria de ser, do mesmo modo, um relato com forte im- 
plicação subjetiva de seu autor. A literatura que compulsamos nos permite apresentar o Movimento dos Focolares como um exemplo da lógica totalitária verificada também em outros grupos religiosos contemporâneos.

No Capítulo 6, discutimos alguns dos atravessamentos institucionais que podemos estabelecer entre o hospital geral, o hospital psiquiátrico, a prisão e o colégio interno. Também esboçamos algumas análises relativas à especificidade dos fenômenos psicossociais que se produzem nas diversas instituições totais, de um modo geral. Tais fenômenos normalmente são desconhecidos e ignorados por profissionais da Medicina, da Pedagogia, da Psicologia, do Serviço Social, do Direito, e por técnicos administrativos que atuam nessas áreas.

Nas Conclusões, tecemos algumas considerações sobre os efeitos éticos da internação como estratégia institucional. Nas instituições totais e disciplinares, há sempre a tentativa de constituição de subjetividades modeladas a partir de certos princípios morais, pedagógicos, educacionais, sociais, religiosos, terapêuticos etc., mas cabe assinalar que isso normalmente fracassa nesses estabelecimentos. Entre outras coisas, porque "onde há poder, há também resistência”, como afirma Foucault, e Goffman, por sua vez, explica que "quando se impõem mundos, se criam submundos". De todos os modos, sempre há um tipo de "educação" como modelagem, formatação, produção de um determinado sujeito social. Mas uma análise paradigmática revelará também o quanto tais estabelecimentos podem ser (des)educativos, pois quando os situamos no contexto histórico e social mais amplo, podemos detectar outras funções sociais a que respondem, para além e, inclusive, aquém do discurso oficial por meio do qual ressaltam seus objetivos institucionais.

Agradecemos às revistas Estudos de Psicologia (Campinas), Psicologia em Estudo (Maringá) e Psicologia USP (São Paulo) a gentileza em autorizar a utilização de nossos artigos neste livro. 


\section{1 \\ O LUGAR DAS INSTITUIÇÕES ${ }^{1}$ DISCIPLINARES NA SOCIEDADE CONTEMPORÂNEA}

Estamos no início do século XXI, atravessando grandes transformações socioculturais produzidas pelo impacto do desenvolvimento tecnológico e da informática no cotidiano. Novas formas de relacionamento, de produção, de consumo, de produção de subjetividade se manifestam. As técnicas de vigilância, de punição, de controle social e de produção de sujeitos também estão se sofisticando a partir do suporte da tecnologia de ponta. Mesmo nesse contexto de mudanças, as antigas instituições totais e disciplinares ainda não desapareceram da sociedade contemporânea. Pelo contrário, há uma

1 Neste capítulo, vamos manter o termo "instituição total”, tal como consta na versão da tradução brasileira do livro de Goffman (1987), mas distinguimos os conceitos de instituição e de estabelecimento institucional. Como exemplo de instituições, teríamos: a linguagem, as relações de parentesco, o trabalho, a educação, a religião, o Estado etc. $\mathrm{Na}$ instituição religião, teríamos como uma de suas organizações, a Igreja Católica e seus estabelecimentos seriam constituídos por paróquias, seminários, conventos, casas religiosas etc. A Doença Mental seria instituição do Paradigma Psiquiátrico, e o manicômio ou o hospital psiquiátrico constituiriam seus estabelecimentos. A Saúde Mental seria a instituição do Paradigma Psicossocial e os Caps, Naps, HD, Ambulatórios, UBS, centros de convivência etc. seriam estabelecimentos. A Educação seria a instituição social, enquanto escolas, colégios internos, universidades etc. seriam seus estabelecimentos. 
florescente indústria funcionando ativamente no sistema prisional (Paixão, 1991; Salla, 2000; Conselho Federal de Psicologia, 2008, 2010a), nos novos pavilhões construídos para a Fundação Casa, antiga Fundação para o Bem-Estar do Menor (Febem), de São Paulo, entidade estudada por Guirado (1986) e por Altoé (2008, 2009a, 2009b), e nos inúmeros presídios que se espalham pelo interior do estado de São Paulo (Behring; Boschetti, 2006).

Nessa categoria de estabelecimentos ainda entram os hospitais psiquiátricos (Levinson; Gallagher, 1971; Castel, 1978; Goffman, 1987; Foucault, 1999a; Benelli; Costa-Rosa, 2003a), os internatos escolares em geral (Rego, 1979; Hesse, 1970, 1980; Perrone-Moisés, 1988; Musil, 1986; Lautréamont, 1986; Pompéia, 1997; Benelli, 2002; Rizzini, 2004; Silva, 2007; Silva; Rabinovich, 2007; Schunemann, 2008), colégios agrícolas com internato (Morais et al., 2004; Pires, 2005; Barroso, 2008; Monteiro; Gonçalves, 2012), os asilos para idosos, os orfanatos (Marcílio, 2000, 2006; Rizzini, 2008), os quartéis e casernas militares, as escolas para formação de policiais militares (Cruz, 1989).

Também podem ser incluídos nessa lista os seminários católicos que acolhem adolescentes e jovens universitários em regime de internato para prepará-los para o sacerdócio (Cabras, 1982; Trevisan, 1985; Tagliavini, 1990; Rocha, 1991; Ferraz e Ferraz, 1994; Benelli, 2006, 2007; Benelli; Costa-Rosa, 2002, 2003b), as casas de formação para indivíduos que pretendem ingressar como membros de instituições religiosas (Pereira, 2004; Benelli; Costa-Rosa, 2006) e as plataformas petrolíferas marinhas (Losicer, 2004, p.101-14).

Finalmente, como parte dessa categoria de estabelecimentos, ainda há as entidades que acolhem e abrigam em regime de internato, crianças e adolescentes consideradas em situação de risco (Assis, 1997; Rizzini, 2008; Marcílio, 2006; Rizzini; Pilotti, 2009), os estabelecimentos onde adolescentes cumprem medidas socioeducativas em regime de semiliberdade (Saliba, 2006) e de internação (Conselho Federal da Ordem dos Advogados do Brasil..., 2006; Gomes da Costa, 2006a, 2006b; Neves, 2007; Roman, 2007; Zanchin, 2010; Conselho Federal de Psicologia, 2010b; Poletto, 2013) 
etc. De todo modo, estamos mais interessados na "lógica disciplinar e total", como estratégia de organização de estabelecimentos institucionais de internação, o que nos permite compreender tais estabelecimentos.

Seria possível discutir longamente sobre a questão de que tipo de sociedade predomina na realidade brasileira, na qual trabalham os profissionais das ciências humanas: se ela constitui ainda uma sociedade de soberania (Suplício), se já configura uma sociedade disciplinar (Panóptico) - conforme Foucault (1999b) - ou se está se tornando uma sociedade de controle (Sinóptico). A impressão é de que no Brasil haveria um pouco de tudo, dependendo da classe social em questão (Benelli, 2004a) ou do recorte histórico realizado (Koerner, 2006). Provavelmente, os ricos já estão inseridos numa sociedade de controle, tal como configurada por Deleuze (1992). Mas a prisão brasileira está mais para a masmorra da sociedade de soberania, como revela o filme Carandiru, do que para a prisão norte-americana disciplinar do filme $U m$ sonho de liberdade. A escola pública que atende os pobres parece estar longe da sofisticação disciplinar foucaultiana (Guimarães, 1995), uma vez que funciona muito precariamente e sua função parece ser a simples exclusão e o impedimento do acesso dos pobres a condições de vida que não estão mesmo previstas para todos. Depois de vinte anos da promulgação do Estatuto da Criança e do Adolescente (ECA) (Brasil, 1990), a construção da cidadania integral para crianças e adolescentes oprimidos ainda é um projeto a ser conquistado (Benelli; Costa-Rosa, 2011).

Observando concretamente a realidade atual, sabemos que o poder e as práticas disciplinares, no século XXI, estão mais sofisticados e qualitativamente mais dispersos na vida social como um todo. Mas nossa perspectiva de análise neste estudo, sem desprezar esse fato, se concentra e focaliza universos institucionalizados mais restritos, pois a atuação dos profissionais da Saúde Coletiva (psicólogos, terapeutas ocupacionais, assistentes sociais, médicos, psiquiatras etc.) dificilmente se ocupa com a totalidade do campo social, que é considerado como um importante pano de fundo. 
Nossa ação profissional é normalmente situada em contextos institucionais específicos. Nesses ambientes, notamos que continuam sendo implementadas inclusive as estratégias mais grosseiras de normalização disciplinar mapeadas por Goffman (1987) e Foucault (1999b), apesar da sofisticação trazida pela tecnologia: telefone celular, internet, equipamentos de monitoração de lojas, empresas, ruas e praias públicas com câmeras, rastreamento via satélite, informatização do controle e gerenciamento de pessoas nos mais diversos tipos de estabelecimentos etc.

Particularmente, no que se refere à Saúde Mental, no âmbito maior da Saúde Coletiva, devido ao clássico descuido e falta de investimentos governamentais, continuamos com instituições nas quais vigoram práticas totalitárias tão rudimentares ainda que pudéssemos considerar tais estabelecimentos verdadeiras "excrescências" não só do ponto de vista temporal, mas também quanto à própria transformação e sofisticação das tecnologias de controle.

Sendo a sociedade um tecido formado por uma rede de instituições sociais, os problemas psicossociais devem ser contextualizados no plano institucional e sociopolítico, dos quais emergem para serem adequadamente equacionados, sob pena de permanecermos em considerações funcionalistas que apenas mascaram a realidade do poder e da política, reduzindo-os a questões de ordem "psicológica" ou "sociológica" individuais. Muitas vezes, provavelmente, o que tomamos como efeito colateral é, na verdade, o produto principal da ação institucional, apesar de todos os seus discursos altruístas, plasmados em seus projetos oficiais.

Podemos afirmar que dominação, aumento da alienação social, adaptação sociocultural e mistificação ideológica são funções das diversas instituições sociais na sociedade burguesa capitalista. As Ciências Humanas emergentes nos séculos XIX e XX nasceram com esse mandato de gerenciamento das populações, para a manutenção do sistema (Foucault, 1999b). Desde sempre, e muito antes, essa também foi a função social da religião: manutenção ideológica do sistema social, na Antiguidade e no Mundo Medieval. Na Mo- 
dernidade, o controle social estatal ganhou ares de cientificidade (Foucault, 1999b).

O que nos ocupa neste estudo é a análise de instituições entendidas como elementos de um dispositivo articulador das relações entre produção de saberes e modos de exercício do poder. Por isso retomamos a descrição de determinadas instituições: aquelas que, num dado momento histórico, se constituem em peças na engrenagem de um tipo específico de sociedade, que Foucault (1984; 1999b) nomeou como "instituições disciplinares". Nesse sentido, o que a genealogia de Foucault nos proporciona é uma análise pragmática da nossa situação atual, haja vista que ainda vivemos numa sociedade disciplinar, pelo menos no que diz respeito a uma boa parte da vida social alijada da produção e consumo de tecnologia de ponta. ${ }^{2}$ A partir dos estudos que realizamos, entendemos que um elemento estrutural das instituições, em geral, é o descompasso e a contradição entre o plano estabelecido em seus estatutos e as práticas implementadas em seu projeto cotidiano. Essa cisão formal encontra seu sentido no fato de que o sucesso de uma instituição depende do seu aparente fracasso como uma organização formal que se dispõe a realizar alguns objetivos específicos por meio dos estabelecimentos que implementa.

Foucault (1999b) ressalta que a principal função das instituições no estrato sócio-histórico da sociedade disciplinar é a de normalização, implementando práticas classificatórias hierarquizantes e distribuindo lugares. Desse modo, o atual campo enunciativo que possibilita "ver" e "falar" algo (remetendo às práticas) aprisiona e aliena ambos os polos (agentes institucionais dirigentes e clientela).

2 Koerner (2006) apresenta um interessante estudo no qual revela que a prisão brasileira nunca se realizou como um panóptico tropical. A partir da análise da relação entre práticas punitivas estatais, disciplina escravista e discurso jurídico no Brasil do século XIX, Koerner afirma a fecundidade da perspectiva foucaultiana para a análise das práticas de produção da sujeição e do discurso jurídico na sociedade contemporânea. Seu trabalho sugere a necessária articulação entre os temas e métodos postos por Foucault e os resultados de pesquisas históricas sobre as especificidades estruturais e culturais da sociedade brasileira, bem como sobre as instituições que ela cria ao longo do tempo. 
O que um estabelecimento visa é controlar os desvios dos sujeitos enquanto indivíduos, esquadrinhando seus comportamentos e efetuando sobre eles uma vigilância constante. Quase poderíamos dizer que os diversos atores institucionais "não sabem o que fazem", afinal, é seu ser social que determina sua consciência e suas práticas. Sabemos que sua ação é historicamente condicionada e determinada pelas condições sociais gerais de produção e reprodução da existência.

Também é verdade que se uma instituição cumprisse o que se propõe a realizar, por meio das organizações, estabelecimentos e dispositivos nos quais se encarna, ela se dissolveria. E as instituições tendem a resistir aos processos de dissolução, por isso gastam grande parte de suas energias em esforços de automanutenção. Mas temos o direito de exigir das instituições o cumprimento do "contrato simbólico" (Costa-Rosa, 2000, 2006), questionando até que ponto os instrumentos utilizados têm alguma conexão com a possibilidade de cumprirem suas promessas.

Podemos afirmar que a institucionalização da vida do indivíduo produz um tipo de subjetividade específica, trabalhando na sua formação mediante práticas objetivantes e subjetivantes que incidem diretamente na sua constituição subjetiva, promovendo a explicitação de várias de suas possibilidades neuróticas, psicóticas e perversas. $^{3}$

A metodologia de investigação tipicamente psicológica é baseada na captação de discursos e práticas que, de acordo com o pensamento de Foucault (Dreyfus; Rabinow, 1995, p.216-24), pode ser situada no paradigma disciplinar. A “observação” implica os a priori epistemológicos da visibilidade, vigilância e exame, que produzem relatórios de dados coletados num campo de investigação, elas constituem as técnicas objetivantes. As técnicas subjetivantes

3 Isso pode ser verificado, por exemplo, em Guirado (1986); Castel (1978); Goffman (1987); Foucault (1999b); Benelli (2002, 2003b); Cruz (1989); Tagliavini (1990); Ferraz e Ferraz (1994); Benelli e Costa-Rosa (2002). Embora muitos desses autores não utilizem explicitamente a expressão "produção de subjetividade", eles caracterizam bem sua produção, destacando os efeitos iatrogênicos de processos de institucionalização total de pessoas. 
são derivadas de modalidades tecnológicas da "confissão": sessões de associação livre, de entrevistas e questionários, estratégias que colocam o homem para falar sobre si.

É interessante notar que a Psicologia parece tratar do comportamento, da conduta, das emoções, da personalidade e do psiquismo que estariam alojados em algum lugar da interioridade do corpo do indivíduo. Mas Foucault nos faz atentar para outros aspectos: o olhar, a visibilidade, a vigilância, os exames e testes que mensuram, a arquitetura dos edifícios, as regras escritas e as informais e os detalhes da prática cotidiana nas instituições. Todos esses elementos seriam operadores e fazem parte do processo de produção da psicologização do ser humano e do processo de construção da interioridade psíquica do indivíduo.

A prática medieval católica da confissão sacramental, por exemplo, foi um interessante instrumento para que o indivíduo falasse a verdade sobre si, obrigando-o a falar, sobretudo, de suas práticas sexuais pecaminosas (Foucault, 1988, p.22ss.). Na modernidade, o confessionário do padre foi substituído pelo consultório e pelo divã do psicólogo, lugar onde o cliente produz suas associações livres, que normalmente podem ter um forte conteúdo sexual. Foi olhando para si, meditando e refletindo sobre si mesmo, sob o olhar vigilante do outro, que os homens foram se individualizando, acreditando em sua singularidade pessoal. Apenas a partir do Renascimento, os artistas começaram a assinar suas obras de arte, denotando assim que estavam alcançando uma individualidade até então desconhecida no Mundo Medieval e na Antiguidade.

O psiquismo foi produzido no homem por meio de discursos filosóficos e científicos, mas também foi construído por meio de técnicas e por práticas inventadas para a docilização e adestramento dos corpos humanos. Curiosamente, foram invenções e tecnologias físicas e concretas que produziram o surgimento da experiência do fenômeno psíquico no ser humano. A vigilância externa foi interiorizada como auto-observação, o confinamento e o silêncio levaram à introspecção, as normas, os regulamentos, as regras implícitas e explícitas mobilizaram a conduta, a postura correta; os relatórios 
dos casos, as provas, avaliações e exames obrigaram o indivíduo a se comportar adequadamente. Desse modo, as relações de poder engendraram a interioridade psicológica.

A metodologia psicológica de investigação não pode escapar de suas próprias condições de possibilidade: ela tende a tomar a realidade como constituída por sujeitos e objetos, buscando comumente sua normalização totalizadora. As práticas da Psicologia produzem tanto a objetivação (disciplinar) quanto a subjetivação (confessional), criando seus objetos e sujeitos. O saber que suas práticas produzem é essencial para a expansão do biopoder (Foucault, 1988) na sociedade contemporânea. A potência do biopoder consiste na definição da realidade bem como na sua produção.

Os saberes psi devem abrir mão do poder de controle que lhes foi historicamente delegado, quando se encomendava que eles gerenciassem a loucura e controlassem os distúrbios da população. Superando a mera função de mantenedores da ordem pública, renunciando à condição de instrumentos promotores de segurança pública ao administrarem a "periculosidade social" dos indivíduos desviantes, os profissionais psi podem orientar sua ação na direção de uma ética singularizante.

$\mathrm{Na}$ sociedade capitalista, as instituições metabolizam a contradição principal (capital/trabalho) mediante diversas estratégias. As relações de poder são escamoteadas e interpretadas de um modo funcionalista: tendência a uma psicologização interiorizante e individualizante ou a uma sociologização que universaliza os interesses da equipe dirigente (representante das forças hegemônicas sociais e institucionais), negação das contradições sociais reais e um processo de naturalização que elude a historicidade dos fatos (Albuquerque, 1980).

Acreditamos ser necessário pensar as relações de poder situadas no conjunto de práticas sociais que produzem os sujeitos como corpos dóceis, adestrados e seres desejantes (Foucault, 1999b). Uma articulação pertinente dos fenômenos emergentes no contexto institucional pode ser elaborada num processo de análise institucional, procurando superar posicionamentos fun- 
cionalistas ingênuos. Pensamos que as dificuldades e problemas das instituições totais não se modificariam apenas com novos métodos e técnicas de gerenciamento institucional. A inércia do instituído tende a mover os atores institucionais na direção de receitas que prometam soluções mágicas e rápidas para seus impasses e conflitos. Assim, buscam-se reformas para manter tudo como está, produzindo modificações em aspectos secundários que geram somente efeitos paliativos (Baremblitt, 1998).

Seria preciso ousadia para modificar o eixo central das discussões: teríamos que problematizar o objeto institucional das diversas instituições totais, "desnaturalizando", "despsicologizando", "dessociologizando" o homem que aí é processado, tomando-o como um sujeito infinitamente mais complexo e multifacetado do que a caricatura empobrecida que faz dele um personagem habitante do universo institucional totalitário.

Consideramos que é necessário analisar as diversas práticas institucionais (formativas, educativas, pedagógicas, terapêuticas, correcionais, socioeducativas), problematizando seus pressupostos subjacentes, procurando detectar como e até que ponto tais ações funcionam como filtros de transformação seletiva e deformante de qualquer proposta inovadora.

Trata-se mesmo de promover uma revolução conceitual: dependendo de como vemos determinado objeto, partimos da consideração de sua suposta natureza essencial para a produção de saberes e técnicas para trabalhá-lo. Os meios e os fins seriam então decorrentes dessa natureza presumida do objeto. É por isso que acreditamos na importância de uma análise das práticas, daquilo que fazemos no contexto institucional. O fazer embute em si uma teoria, um objeto, saberes e técnicas: produz subjetividade, modos de existência, sujeitos, universos de materialidade social. Tal processo pode se submeter ao sentido do processo hegemônico de produção de subjetividade, mas também pode orientar-se no sentido de produções singularizadas.

Nesse sentido, Costa-Rosa (2000, p.151-2) estabelece alguns parâmetros importantes na composição de um determinado para- 
digma, que devem ser observados quando procuramos estudar e caracterizar uma determinada instituição, evitando perspectivas funcionalistas: a) concepção do "objeto" e dos "meios de trabalho", que diz respeito às concepções do objeto institucional e concepção dos meios e instrumentos de seu manuseio (inclui ainda o aparelho jurídico-institucional, multiprofissional e teórico-técnico, além do discurso ideológico); b) formas de organização do dispositivo institucional: como se organizam as relações intrainstitucionais, organograma, relações de poder e de saber; c) formas de relacionamento com a clientela; d) formas de seus efeitos típicos em termos de resolutividade e éticos, que inclui os fins políticos e socioculturais amplos para os quais concorrem os efeitos de suas práticas.

As instituições totais podem ser inseridas num paradigma denominado asilar e podemos compreender claramente sua dinâmica ao situá-las nesse contexto (Costa-Rosa, 2000). Tomamos a hipótese da sociedade disciplinar e do modo de organização e funcionamento das instituições totais enquanto possibilidades paradigmáticas de organização tanto da vida social quanto institucional, nas análises que vamos desenvolver sobre o fenômeno dos estabelecimentos de internação.

Acreditamos que muitas questões pedagógicas, psicológicas, psiquiátricas, hospitalares, da saúde coletiva etc. podem se tornar mais inteligíveis quando enquadrados num marco institucional global. Entendemos que os problemas institucionais são também problemas sociais. Soluções técnicas muitas vezes não são suficientes para resolvê-los. Eles exigem soluções políticas para sua metabolização. A política não é uma questão técnica (eficácia administrativa) nem científica (conhecimentos especializados sobre gerenciamento ou administração). É ação e decisão coletiva quanto aos interesses e direitos do próprio grupo social. Uma perspectiva institucional, histórica, dialética e crítica, ampla e paradigmática pode ser uma interessante e complexa abordagem para problemas também complexos. 


\section{2 \\ GOFFMAN E AS INSTITUIÇÕES TOTAIS EM ANÁLISE}

Goffman (1987, p.7) realizou uma pesquisa de campo no Sta. Elizabeths Hospital, em Washington D.C, em 1955-1956, nos Estados Unidos, cujo objetivo era tentar conhecer o mundo social do internado em hospital, procurando captar a perspectiva subjetiva do internado. Ele passava os dias com os pacientes e a direção do hospital sabia dos seus objetivos. Partindo dessa pesquisa de campo e utilizando uma ampla bibliografia, o autor elaborou o conceito de "instituição total", caracterizando-a pelo seu "fechamento" mediante barreiras que são levantadas para segregar os internados do contato social com o mundo exterior. As proibições à saída estão muitas vezes incluídas no plano físico e arquitetônico da mesma. Seu traço principal é que ela concentra todos os diferentes aspectos da vida de uma pessoa (trabalho, lazer, descanso) no mesmo local e sob a autoridade de uma equipe dirigente.

Goffman (1987, p.11) define a instituição total "como um local de residência e de trabalho onde um grande número de indivíduos com situação semelhante, separados da sociedade mais ampla por um período considerável de tempo, levam uma vida fechada e formalmente administrada". ${ }^{1}$ As instituições totais podem ser enu-

1 Queremos ressaltar que o termo "totalitário" é bastante preciso e não pode ser estendido a qualquer situação institucional, sem mais. Para que um estabele- 
meradas em cinco categorias: a) as criadas para cuidar de pessoas que são consideradas incapazes e inofensivas, tais como as casas de cegos, asilos para idosos, órfãos e indigentes; b) locais estabelecidos para cuidar de pessoas consideradas incapazes de cuidar de si mesmas e que são também uma ameaça não intencional para a comunidade, como sanatórios para tuberculosos, hospitais para doentes mentais e leprosários; c) as criadas para proteger a comunidade contra ameaças e perigos intencionais, sem se importar muito com o bem-estar das pessoas segregadas, onde se inserem as cadeias, penitenciárias, campos de prisioneiros de guerra e campos de concentração; d) as erigidas com a intenção de realizar de um modo mais adequado alguma tarefa instrumental, tais como: quartéis, navios, escolas internas, campos de trabalho, colônias; e) os estabelecimentos destinados a servir de refúgio do mundo, que também podem servir como locais de instrução para religiosos, tais como: abadias, mosteiros, conventos e outros claustros.

Essa classificação não pretende ser completa, totalmente clara nem definitiva. É possível traçar um perfil geral a partir dessa lista de instituições, mas esse esquema não parece ser exclusivo delas e nem todos os traços se aplicam a todas elas (Goffman, 1987, p.16-17).

Os estabelecimentos fechados por muros que delimitam seu território apresentam algumas características distintivas: os indivíduos internados têm, como parte de suas obrigações, uma participação visível nos momentos adequados às atividades do estabelecimento. Isso exige deles uma mobilização da atenção e do esforço muscular, além de certa submissão pessoal à atividade em questão. Essa participação obrigatória na atividade do estabelecimento é considerada como um símbolo do compromisso e da adesão do indivíduo, implicando também a aceitação por ele das consequências da participação para uma definição de sua natureza,

cimento institucional possa ser considerado "total", ele deve ser constituído por uma lógica totalitária, cujos parâmetros encontramos nas análises de Goffman (1987). 
papel e posição de internado. Os problemas de adesão visíveis nas atividades programadas do estabelecimento são indicadores do modo como os indivíduos se adaptam ou não ao papel e definição que o estabelecimento lhes impõe (Goffman, 1987, p.17-18).

Cada fase da atividade diária do internado é realizada na companhia imediata de um grupo relativamente grande de pessoas, todas tratadas da mesma forma e obrigadas a fazer as coisas em conjunto. Todas as atividades são rigorosamente estabelecidas em horários contínuos, de modo que uma leva à outra e toda sequência de atividades é imposta de cima, por um sistema de regras explícitas e pelo grupo dirigente. As várias atividades obrigatórias estão reunidas num plano racional e único, supostamente criado para atender aos objetivos oficiais do estabelecimento institucional. Há um controle de muitas das necessidades humanas pela organização burocrática de grupos inteiros de internados. $\mathrm{O}$ controle e a vigilância sobre o conjunto dos internados (sob a responsabilidade do grupo dirigente) fazem que todos cumpram as normas estabelecidas e, ao mesmo tempo, salientam a infração de um indivíduo no contexto global da obediência visível e constantemente examinada dos demais.

Existe uma divisão básica entre um grande grupo controlado (os internados) e uma pequena equipe dirigente que o supervisiona. O grupo dos internados vive no estabelecimento e tem um contato restrito com o mundo externo. A equipe dirigente, muitas vezes, trabalha num sistema de oito horas por dia e pode estar integrada no mundo externo. Cada um desses grupos tende a conceber o outro mediante estereótipos limitados e hostis. Os internados podem ver os dirigentes como autoritários, condescendentes, arbitrários e mesquinhos. Os dirigentes veem os internados como amargos, reservados e não merecedores de confiança. Os primeiros tendem, pelo menos sob alguns aspectos, a sentir-se inferiores, fracos e censuráveis. Os segundos costumam se sentir superiores e corretos. A mobilidade entre os dois estratos é grosseiramente limitada. Geralmente há uma grande distância social entre ambos e essa é frequentemente prescrita. Há também restrição de informações, sobretudo, as relativas aos planos dos dirigentes para os internados, 
que não costumam ter conhecimento quanto ao seu destino. Assim, desenvolvem-se dois mundos sociais e culturais diferentes, que caminham juntos com pontos de contato oficiais, mas com pouca interpenetração.

O trabalho dentro dessas instituições, nas quais os internados têm o atendimento de todas as suas necessidades planejadas, apresenta características peculiares. $\mathrm{O}$ trabalho pode ser muito ou pouco, pode estar relacionado a um sistema de recompensas secundárias ou prêmios que estimulam o internado a conquistá-los. Como não há pagamento em dinheiro, mediação usual utilizada no mundo externo, há uma fraca motivação para executar o trabalho, para gastar mais ou menos tempo no seu término. $\mathrm{O}$ trabalho é geralmente uma forma de preencher o tempo ou um castigo propriamente dito. Ele contribui para o funcionamento do estabelecimento, mas não é essencial. Existe uma incompatibilidade entre o funcionamento das instituições totais e as relações sociais capitalistas que regem o trabalho assalariado na sociedade atual. Elas parecem mais próximas do modelo feudal ou escravista. A família também é outro elemento incompatível com a instituição total e seus estabelecimentos. A vida familiar e doméstica é contrastada com a vida grupal dos internados, que dificilmente podem manter uma vida doméstica significativa. A instituição total suprime um círculo completo de lares reais ou potenciais (Goffman, 1987, p.22).

Os analisadores para entender o funcionamento das instituições totais são os seguintes: a dinâmica do mundo do internado, a especificidade do mundo da equipe dirigente e os cerimoniais institucionais. Com Goffman (1987), aprendemos a práxis que opera na instituição total e ele desvenda a teoria da prática, ao elaborar uma teoria sobre a prática que observa.

\section{O mundo do internado na instituição total}

Inicialmente, vamos descrever, a partir de Goffman (1987, p.23ss.), "o mundo do internado no estabelecimento total". O no- 
vato, quando chega ao estabelecimento, traz consigo uma cultura (uma forma de vida e um conjunto de atividades, de direitos, deveres, costumes e hábitos) que era aceita sem discussão, até aquele momento, em sua situação normal e cotidiana. Esse pano de fundo sociocultural deriva geralmente do mundo e ambiente familiar do indivíduo, dando-lhe uma organização pessoal mais ou menos estável, uma certa identidade, que se encaixava no ambiente civil mais amplo. O novato possuía um conjunto de experiências que confirmavam uma concepção favorável de seu eu e lhe permitia agir e reagir, utilizando um conjunto de defesas exercidas de modo tal que pudesse enfrentar conflitos, dúvidas e fracassos.

As instituições totais não parecem promover uma substituição cultural completa. Mas se a estada do internado for muito longa, pode ocorrer uma perda do traquejo cultural que o torna temporariamente incapaz de enfrentar alguns aspectos de sua vida diária na vida civil cotidiana. Para o internado, a significação do "dentro" não existe independentemente do sentido de "estar fora" ou "sair". Assim, as instituições totais criam e mantêm um tipo específico de tensão entre o mundo doméstico e o propriamente institucional, usando essa tensão persistente como uma força estratégica no controle dos homens.

O ingresso na instituição total implica mudanças radicais e o início de uma "carreira moral" para o internado. "O novato chega ao estabelecimento com uma concepção de si mesmo que se tornou possível por algumas disposições sociais estáveis no seu mundo doméstico”, afirma Goffman (1987, p.24). Já no seu ingresso, começa a ser despido desses referenciais identificatórios e a passar por uma série de rebaixamentos, degradações, humilhações e profanações do conceito que tinha de si mesmo. Sua "carreira moral" vai passar por mudanças radicais e progressivas, suas crenças a respeito de si mesmo e sobre as pessoas significativas para ele são questionadas, entram em crise e começam a desmoronar.

Goffman (1987, p.111) utiliza o termo "carreira moral" em um sentido amplo, com a finalidade de indicar qualquer trajetória percorrida por uma pessoa ao longo de sua vida, permitindo ainda uma 
perspectiva tanto dos aspectos mais íntimos e pessoais, quanto das posições oficial, jurídica e pública do indivíduo, dentro de um complexo institucional. A "carreira moral" indica o processo da vida toda do indivíduo, tanto em direção ao sucesso quanto ao fracasso, dentro do estabelecimento. Esse processo tem momentos típicos, tais como início da vida institucional, crises, evoluções, desenvolvimentos de adaptação, de rebeldia, de submissão, de ruptura etc.

\section{Processos institucionais de modelagem do comportamento}

Os processos de mortificação do "eu" são definidos por Goffman (1987, p.24-39) como "os processos pelos quais o 'eu' da pessoa é mortificado são relativamente padronizados nas instituições totais". Conhecê-los é importante para desmontá-los e por isso vamos descrever alguns deles a seguir:

a) As barreiras impostas entre o internado e o mundo externo apresentam-se como uma primeira mutilação do eu, pois o indivíduo é despido de seu papel social: na vida externa, civil e cotidiana, a sequência de horários dos papéis desempenhados pelo indivíduo (no ciclo vital e nas rotinas diárias) assegura que um papel realizado não impeça a realização ou a ligação com outros. Porém, a participação numa instituição total perturba automaticamente a sequência dos papéis sociais. A separação do internado com o mundo exterior dura o tempo todo e pode continuar por anos. Inicialmente se proíbem as visitas vindas de fora e as saídas do estabelecimento, produzindo uma ruptura aguda com os papéis anteriores e uma avaliação, por parte do indivíduo, da perda do papel que ele costumava desempenhar. Quando a entrada é voluntária, o que o estabelecimento corta com veemência é algo que já estava em processo de desligamento, pois o novato já estava se afastando, gradual e parcialmente, de seu mundo doméstico. Alguns dos papéis sociais exercidos com plenos direitos na vida civil podem ser recuperados 
pelo internado se, e quando, ele voltar para o mundo externo. Outras perdas são irrecuperáveis e podem ser dolorosamente sentidas, tais como: tempo não utilizado na preparação escolar e profissional, no namoro, na criação dos filhos etc.;

b) Processos de admissão, com a preparação da pasta ou arquivo pessoal. A equipe dirigente geralmente monta uma pasta ou um arquivo com os dados pessoais do novato: pode obter uma história de vida, tirar fotografias, pesar, tirar impressões digitais, atribuir números, procurar e enumerar bens pessoais para que sejam guardados, despir, dar banho, fazer exames médicos, desinfetar, cortar os cabelos, exigir apresentação de documentos pessoais, distribuir roupas do estabelecimento, dar instruções quanto às regras, designar um lugar para o internado. Por meio desses procedimentos, o novato é enquadrado e admite ser conformado e codificado num objeto que pode ser colocado na máquina administrativa do estabelecimento para ser modelado suavemente pelas operações de rotina. Com esse processo de padronização, o indivíduo passa a ser tratado de um modo completamente abstrato, fazendo-se tábula rasa de todas as suas autoidentificações anteriores;

c) Testes de obediência para conseguir a cooperação inicial do novato. A equipe dirigente muitas vezes pensa que a disposição do novato para apresentar respeito adequado em seus encontros iniciais, face a face, é um sinal de que aceitará docilmente o papel de internado rotineiramente obediente. Ela pode então estruturar o momento de informação inicial ao internado quanto às regras e obrigações, de modo a desafiá-lo e humilhá-lo, obrigando-o a manifestar se tenderá a ser um revoltado permanente, caso ele responda de modo altivo e revide com arrogância, ou se obedecerá sempre, respondendo com humildade e submissão. Esse teste de obediência ou de quebra de vontade pode fazer que um internado que se mostre insolente seja castigado de modo imediato e visível. O castigo aumenta até que ele explicitamente peça perdão e se humilhe. São típicas as recepções de "boas-vindas", trotes agressivos e humilhantes com que são recepcionados os novatos, dando-lhes uma noção clara de sua situação: ocupam o lugar mais baixo entre 
os internados. Geralmente são chamados por termos que sempre lhes recordam sua posição inferior: novato, calouro ou outros. $\mathrm{O}$ processo de admissão pode ser caracterizado como uma despedida e como um começo e seu ponto médio pode ser marcado pela experiência da nudez;

d) Despojamento dos bens, emprego, carreira. Ingressar na instituição total não significa apenas uma brusca mudança de status social, mas também pode implicar a perda de propriedade, fato importante, porque as pessoas costumam ter as coisas como extensão de si mesmas. Os bens e objetos pessoais são parte do indivíduo. Provavelmente, a mais significativa dessas posses seja o próprio nome do indivíduo e sua perda é uma grande mutilação. Despojado dos bens, o estabelecimento lhe providencia substituições padronizadas que são distribuídas uniformemente. Esses bens substitutos geralmente levam a marca do estabelecimento e podem ser recolhidos em intervalos regulares, quando são desinfetados de identificações. $\mathrm{O}$ internado pode ser obrigado a devolver objetos que ainda poderiam ser utilizados, antes de receber substituições. Pode haver também confiscos periódicos e buscas de propriedade acumulada, que reforçam a ausência de bens.

As ordens religiosas têm longa tradição na prática da separação entre o indivíduo e seus bens, tendo em vista o despojamento das posses, o desapego dos bens e a vivência da pobreza evangélica, como se pode observar na regra beneditina, por exemplo, no seu capítulo 55, no qual isso é claramente estabelecido (Lapierre, 1993, p.93-5).

Normalmente, um indivíduo dispõe de um conjunto de bens individuais com os quais produz sua aparência pessoal, controlando o modo como se apresenta aos demais. Trata-se de um conjunto de itens como: perfumes, cosméticos, roupas, adereços pessoais, instrumentos para usá-los ou consertá-los e um local seguro para guardar tudo o que ele utiliza e necessita para controlar sua aparência.

Ao ser admitido numa instituição total, é muito provável que o indivíduo seja despido de sua aparência usual, bem como dos equipamentos e serviços com os quais a mantém, produzindo-se uma desfiguração pessoal. Material de higiene e toillete pessoal 
pode ser retirado dele, negado ou guardado longe do seu alcance, para ser devolvido se, e quando, sair. Exemplo desse procedimento encontra-se prescrito na regra beneditina, no seu capítulo 58 (Lapierre, 1993, p.97-9).

Em algumas instituições totais são realizadas ainda mutilações diretas e permanentes no corpo: marcas ou perda de membros, ocasionando a perda de um sentido de segurança pessoal, levando o indivíduo a sentir que está numa ambiente ameaçador, que não lhe garante a integridade física. Também podem obrigar o indivíduo a adotar movimentos, posturas e poses culturalmente consideradas aviltantes e humilhantes, com o objetivo de mortificá-lo. Nas instituições religiosas há alguns gestos clássicos de penitência: beijar ou lavar os pés dos demais, ficar prostrado no chão e ficar de joelhos na presença dos demais membros da comunidade.

O indivíduo também pode ser obrigado a dar respostas verbais humilhantes, sempre dizendo "senhor" quando se dirigir a algum membro da equipe dirigente, por exemplo, caso tenha a necessidade de pedir coisas simples, como fogo para cigarro, um copo d'água, permissão para poder fazer certas coisas, como usar o telefone etc.

$\mathrm{O}$ internado ainda precisa suportar as indignidades de tratamento que outros lhe infligem: pode receber nomes obscenos, xingamentos, indicações maldosas de seus defeitos e gozações. A equipe dirigente ou os demais internados podem também falar entre si, a seu respeito, como se ele não estivesse presente, como uma provocação. $\mathrm{O}$ indivíduo é obrigado a participar e a se submeter a práticas plenas de violência simbólica que são incompatíveis com a concepção que tem de si mesmo.

Nas instituições religiosas, podemos encontrar disposições especiais para garantir que todos os internados realizem, por turnos, os serviços de faxina, limpeza e cozinha, conforme se pode verificar na regra beneditina, no seu capítulo 35 (Lapierre, 1993, p.69-71). Esses serviços domésticos são desvalorizados e desprestigiados, pois usualmente são considerados serviços de empregados sem qualificação, sendo impingidos como mais uma humilhação, com o pretexto de ensinar o internado a servir os demais. Esses trabalhos 
também são realizados pelos internados sem remuneração, tendo sua importância no orçamento do estabelecimento;

e) Exposições contaminadoras físicas, sociais e psicológicas (apelidos, gozações). Nas instituições totais, as fronteiras que o indivíduo estabelece entre seu ser e o ambiente são invadidas e sua pessoa pode ser sistematicamente profanada. Já não pode mais, como no mundo externo, manter objetos investidos por seu "eu" (seu corpo, suas ações imediatas, seus pensamentos e alguns de seus bens) fora de contato com coisas estranhas e contaminadoras.

Uma dessas práticas é a violação de informação quanto à privacidade pessoal do indivíduo. $\mathrm{Na}$ admissão, a pasta pessoal do internado que contém dados relativos à posição pessoal e seu comportamento anterior, incluindo os fatos desabonadores, está sempre à disposição da equipe dirigente. Quando o estabelecimento pretende mudar e alterar as tendências autorreguladoras do internado, pode ainda obter dele confissão individual ou grupal (psiquiátrica, política, militar ou religiosa), dependendo do objetivo da instituição. $\mathrm{O}$ internado deve expor, então, a diferentes audiências, fatos, concepções e sentimentos sobre si mesmo. Exemplo dessa exposição pessoal é dado pelas sessões de mea culpa, de "correção fraterna”, que são mais ou menos acontecimentos regulares e rotineiros nas instituições religiosas católicas.

Os membros da instituição total descobrem, assim, os fatos negativos e escondidos da vida pessoal do internado. Além disso, os dirigentes das instituições ainda podem perceber diretamente alguns desses fatos, por outras formas. Por exemplo, os serviços de rotina e mesmo os elementos arquitetônicos impossibilitam que presos e doentes mentais evitem que os demais os vejam em circunstâncias humilhantes: os exames médicos costumam expor o indivíduo, assim como dormitórios coletivos, banheiros sem portas e celas com grades no lugar de paredes. Provavelmente, a exposição contaminadora mais evidente nessas situações seja a do tipo diretamente físico: a sujeira e a mancha no corpo ou em outros objetos intimamente identificados com a pessoa. Formas de contaminação comuns ainda podem ser: alimento sujo, locais desordenados e 
imundos, toalhas e roupas sujas, água servida já usada por outros para o banho, sanitários sem assento e deteriorados etc.

Em algumas instituições totais, o internado é obrigado a tomar medicamentos orais ou intravenosos, desejados ou não, e a comer o alimento, mesmo sujo, inclusive de modo forçado, caso se recuse a fazê-lo, numa contaminação de seu organismo. O internado também é contaminado por outro ser humano, pelo contato interpessoal imposto, no contexto de uma relação social institucional da qual não pode escapar. Como não controla quem o observa em sua desgraça, ou quem conhece seu passado, está sendo contaminado pela convivência com estas pessoas. É por meio de tais percepções e conhecimento que se exprimem as relações entre eles.

O ápice da contaminação interpessoal tem seu modelo na violação e perseguição sexual, fato também típico nas instituições totais. A intimidade pessoal é totalmente destruída e devassada nesses casos. O hábito de misturar grupos etários, étnicos e raciais em prisões e hospitais psiquiátricos também pode fazer que o internado sinta que está sendo contaminado por contato com companheiros indesejáveis. A vida em grupo exige contato mútuo e permanente exposição entre os internados.

Outra contaminação é produzida pelo sistema de apelidos, que nega ao indivíduo o direito de manter-se distante dos demais, mediante um estilo formal de tratamento, pois a equipe dirigente e os outros internados se arrogam automaticamente o direito de empregar uma forma íntima e acintosa de chamá-lo. Também a relação individual íntima com pessoas significativas para o internado pode ser exposta à contaminação quando, por exemplo, sua correspondência é violada, lida, censurada ou provoca gozação. Isso também pode ser verificado no caráter obrigatoriamente público de visitas vigiadas em prisões. Outro elemento de contaminação se apresenta nas confissões institucionalmente organizadas, quando uma pessoa significativa para o indivíduo precisa ser denunciada e, sobretudo, quando essa pessoa está presente no interrogatório. A confissão de tal relação a estranhos significa uma intensa exposição contaminadora, da relação e das pessoas envolvidas. 


\section{O circuito fechado e totalitário no estabelecimento institucional}

Goffman (1987, p.40-5) detectou uma estratégia institucional denominada "circuito", responsável por uma perturbação na relação usual entre o ator individual e seus atos. No "circuito", membros da equipe dirigente criam uma resposta defensiva para o internado e depois utilizam essa resposta para seu ataque seguinte. $\mathrm{O}$ indivíduo descobre que sua resposta protetora diante de um ataque à sua pessoa falha na situação, pois não pode defender-se da forma usual ao tentar estabelecer uma distância entre a situação mortificante e seu ego.

$\mathrm{Na}$ vida civil cotidiana, quando alguém precisa aceitar ordens e circunstâncias ultrajantes, pode reagir para salvar as aparências, expressando mau humor, palavrões resmungados, expressões fugidias de desprezo, ironia, sarcasmo e omissão de sinais de deferência. A obediência não corresponde exatamente às atitudes manifestas do indivíduo. Essas mesmas expressões de autodefesa diante de exigências humilhantes ocorrem nas instituições totais, mas não são toleradas pela equipe dirigente, que pode castigar diretamente os internados por esse comportamento e citar o mau humor e a insolência como base para outros castigos.

Como as esferas da vida estão interligadas no contexto institucional, a conduta do internado numa área de atividade é lançada contra ele pelos dirigentes, como comentário e verificação de sua conduta em outro contexto. Fato semelhante não costuma acontecer na sociedade civil, em que a segregação entre o papel e a audiência impede que as confissões e exigências implícitas quanto à pessoa, realizadas em determinado contexto, sejam verificadas em outros.

Um segundo ataque que as instituições totais realizam contra o indivíduo internado, enquanto um ator e um agente, é a tiranização dele mediante um processo de infantilização social, que retira da pessoa sua autonomia, liberdade de ação e capacidade de decisão, perturbando decididamente sua autonomia civil. As menores partes de sua atividade estão sujeitas a regulamentos e julgamentos da 
equipe dirigente. A vida do internado é constantemente vigiada e sancionada do alto, sobretudo no período inicial de sua estada, antes de ele acostumar-se e submeter-se aos regulamentos sem pensar. Cada especificação normativa de conduta priva o indivíduo da oportunidade de equilibrar suas necessidades e objetivos de maneira pessoalmente eficiente, violentando a sua autonomia. $\mathrm{O}$ controle minucioso é extremamente limitador numa instituição total.

Uma das formas mais eficientes de perturbar a autonomia pessoal é a obrigação de pedir permissão ou material para realizar atividades secundárias que o indivíduo poderia executar sozinho se estivesse no mundo externo: fumar, ir ao banheiro, barbear-se, tomar banho, gastar dinheiro, colocar cartas no correio etc. Essa obrigação coloca o indivíduo numa posição submissa e infantilizada, inadequada para um adulto, além de possibilitar que ele sofra outras interferências da equipe diretora: pode ser obrigado a esperar para ser atendido por simples capricho, ser ignorado, interrogado longamente, receber uma negativa etc.

Além da tiranização, o internado também está submetido ao processo de arregimentação, que indica a obrigação de executar a atividade regulada em uníssono com grupos de outros internados. Também existe um sistema de autoridade escalonada: qualquer pessoa da equipe dirigente tem o direito de impor disciplina a qualquer dos internados, o que aumenta claramente a possibilidade de sanção. No mundo externo, o adulto normalmente está sob a autoridade de um único superior no trabalho, sob a autoridade do cônjuge na vida doméstica e a autoridade escalonada da polícia não é onipresente. Os internados, sobretudo os novatos, podem viver aterrorizados e cronicamente angustiados quanto à desobediência das regras e suas consequências, pela onipresença da autoridade escalonada e pelos regulamentos difusos.

As instituições totais perturbam as ações que, na sociedade civil, permitem ao indivíduo atestar para si e para os demais, que goza de certa autonomia no seu ambiente. Ele se considera capaz de decisões adultas e os outros também esperam isso dele. A impossibilidade de manter esse tipo de autonomia, liberdade de ação, 
competência executiva adulta e seus símbolos, pode provocar no internado o horror de sentir-se radicalmente rebaixado no sistema de graduação etária, sendo reduzido à condição de uma criança.

O internado é completamente privado de escolha pessoal, tendo que se acomodar, como puder, às condições ambientais do estabelecimento. A ineficiência pessoal também se apresenta no uso da fala dos internados, pois suas respostas podem ser consideradas como simples sintomas e a equipe diretora pode passar a prestar atenção aos seus aspectos não verbais. Ao infantilizar o internado, as falas da equipe diretora e de seus auxiliares podem se reduzir a expressões retóricas, já que não consideram o internado capaz de uma comunicação adulta.

\section{Diferentes justificativas para os procedimentos mortificantes implementados}

Quanto às justificativas para os ataques ao "eu” do indivíduo, as instituições totais podem ser classificadas em três tipos, de acordo com Goffman (1987, p.47-9). As religiosas reconhecem explicitamente o valor e as consequências das disposições ambientais que mortificam o indivíduo, com seus objetivos espirituais. Os internados nessas instituições podem complementar por si mesmos as mortificações impostas pela equipe dirigente com restrições autoimpostas (jejuns, penitências diversas), pancadas com autoflagelação e a inquisição institucional com a confissão procurada e espontânea. O caminho para Deus é o da ascese.

Num segundo tipo, no qual se incluem os campos de concentração e, em menor extensão, as prisões, algumas mortificações parecem ser utilizadas apenas pelo seu poder de infligir sofrimento ao internado, mas, nesses casos, ele não aceita e nem facilita o trabalho da equipe dirigente.

No terceiro tipo, as mortificações são oficialmente racionalizadas com outros fundamentos: higiene (no caso do uso dos banheiros), responsabilidade pela vida (alimentação e medicação 
forçadas), capacidade de combate (regras do exército e da polícia quanto à aparência pessoal) e "segurança" (restrições nas prisões).

Parece claro que as várias justificativas para a mortificação do "eu" do indivíduo são frequentemente meras racionalizações, elaboradas pela necessidade de controlar minuciosamente a vida diária de um grande número de pessoas, num espaço delimitado e com poucos gastos de manutenção. As mutilações do "eu" ocorrem de qualquer modo, mesmo nos casos em que o internado coopera e os dirigentes têm interesses ideais pelo seu bem-estar.

As pessoas podem decidir, voluntariamente, ingressar numa instituição total e depois lamentarem a perda da livre iniciativa e da possibilidade de tomarem decisões importantes na vida. Entre os religiosos, os internados podem partir de um desejo de abrir mão da decisão pessoal e manter esse desejo. Pensamos que isso ocorre, de algum modo, com aqueles que procuram instituições fortemente hierárquicas, tais como o exército e a polícia. Nessas organizações, a formação se dá em regime de internato temporário e a obediência aos superiores é a regra de ouro: não é preciso pensar muito, basta obedecer. De qualquer modo, as instituições totais são fatais para o "eu" civil do internado, embora a ligação dele com o próprio "eu" autônomo pode variar consideravelmente.

Todos esses ataques ao "eu”, promovidos pelos vários processos de mortificação, tendem a produzir uma profunda tensão psicológica no indivíduo, mas para alguém desiludido do mundo, com fortes sentimentos de culpa ou ainda extremamente fóbico, eles podem provocar alívio psicológico. Essa tensão aguda pode produzir ainda outros sintomas: perda do sono, do apetite, indecisão crônica e permanente.

\section{Mecanismos institucionais de reforma do indivíduo}

O "sistema de privilégios", estudado por Goffman (1987, p.49-54), representa um efetivo fator de reorganização do "eu”. Enquanto é submetido ao processo de mortificação, o internado 
também recebe instruções formais e informais quanto ao sistema de privilégios que vigora no estabelecimento. O "eu" civil e autônomo do internado já foi abalado e colocado em xeque pelas várias mortificações experimentadas e o sistema de privilégios será o fator de reorganização real que incidirá em sua nova configuração.

São três os elementos básicos desse sistema. O primeiro é o conjunto relativamente explícito e formal de "prescrições e proibições”, que normatiza a conduta do internado. Essas regras costumam especificar com detalhes a rotina diária e austera da vida do internado.

Em segundo lugar, contrastando com esse ambiente rígido, apresenta-se um pequeno número de "prêmios" ou "privilégios" claramente definidos, obtidos em troca de obediência, em ação e espírito, à equipe dirigente. Perversamente, muitas dessas satisfações potenciais, elevadas arbitrariamente a privilégios na vida institucional, eram parte integrante da vida cotidiana e corrente do indivíduo, aceitas como indiscutíveis. Beber um café, descansar alguns minutos, fumar, obter um jornal, ver televisão e ir e vir, eram decisões que ele tomava sem pensar muito.

Apresentadas ao internado como possibilidades, essas poucas conquistas parecem ter um efeito reintegrador, pois estabelecem novamente as relações com todo o mundo perdido, suavizam os sintomas de afastamento em relação a esse mundo, à autoimagem e autoconceitos perdidos.

Em terceiro lugar, o elemento "castigo" está integrado no sistema de privilégios. Os castigos são definidos como consequência de desobediência às regras. Um conjunto de tais castigos é formado pela recusa ou retirada, temporária ou permanente, de privilégios, ou ainda pela eliminação do direito de adquiri-los.

Esses privilégios costumam ser altamente valorizados pelos internados, que se acostumam a construir um mundo e uma cultura em torno dos privilégios secundários. Por serem tão importantes e facilmente manipuláveis, seu afastamento é sentido como uma experiência terrível. Existem alguns aspectos específicos do sistema de privilégios: eles são modos de organização peculiares às institui- 
ções totais e a noção de castigo e privilégio não é retirada do padrão civil normal. E ainda, alguns atos são considerados como causadores do aumento ou da não redução da estada no estabelecimento, outros atos são considerados um caminho para reduzir a permanência, incidindo diretamente na possibilidade da liberdade futura. Prêmios, privilégios e castigos são correlacionados a um sistema que manipula locais de trabalho e de descanso, produzindo uma especialização geográfica: alguns locais adquirem valor de castigo e outros equivalem a prêmio ou promoção.

O sistema de privilégios é formado por um número relativamente pequeno de componentes, reunidos de modo intencional e racional e sendo assim apresentado aos internados. É desse modo que se pode manipular indivíduos e obter sua cooperação, sendo que, muitas vezes, eles têm razão em recusá-la.

Esse sistema de privilégios, dentro do contexto do estabelecimento, se relaciona com a criação de uma gíria institucional, por meio da qual os internados podem se comunicar e descrever os acontecimentos decisivos em seu mundo específico. Essa "língua da tribo" pode ser também utilizada pela equipe dirigente, sobretudo nos postos mais baixos e mais próximos dos internados. Ao mesmo tempo em que absorve a gíria local, o internado recém-chegado adquire um conhecimento sobre os vários postos e funcionários, o conjunto de "lendas" sobre a história da instituição e do estabelecimento, as regras da casa, o sistema de privilégios e ainda uma certa informação comparativa sobre a vida em outras instituições semelhantes.

\section{Estratégia de resistência do indivíduo ao processamento institucional}

Goffman (1987, p.54-8) investigou o "sistema de ajustamentos secundários" funcionando na dinâmica institucional dos estabelecimentos totais. Esse sistema, que também está correlacionado ao de privilégios, é constituído de práticas que não desafiam diretamente 
a equipe dirigente, mas permite que os internados obtenham satisfações proibidas ou consigam, por meios proibidos, as satisfações permitidas. Essas práticas podem receber vários nomes na gíria local: "saber que apito tocar", "mexer os pauzinhos", "conivências", "tratos" etc. O lugar onde melhor se desenvolve esse sistema costuma ser na prisão, mas ele também surge em outras instituições totais. Essa forma de ajustamento é uma reação do indivíduo que não se submete às mortificações infligidas à sua pessoa, e dá uma prova clara de que ele ainda é um homem autônomo, cuja vontade não foi quebrada e que mantém um certo controle no seu ambiente. Os ajustamentos secundários se tornam verdadeiros nichos onde o indivíduo pode alojar e abrigar seu "eu”.

Os internados também criam algum tipo de código e meios de controle social informal para impedir que um deles informe a equipe dirigente quanto aos ajustamentos secundários de outros. Esse controle pode ser feito mediante cooptação e coerção com ameaça pela força e violência. Ainda é possível manter o outro calado, de modo mais ou menos sutil, quando esse outro "tem o rabo preso": os demais internados têm informações confidenciais sobre ele, que muito o prejudicariam caso chegassem aos ouvidos da equipe dirigente ou de seus auxiliares. Desse dispositivo de segurança, surge uma tipologia social que classifica indivíduos como "dedo duro", "ratos", "informantes", "espiões", "polícia secreta", de um lado, e os "boas-praças" de outro. Os internados que possuem fácil acesso a bens ilícitos disponíveis são outro tipo social, designando os indivíduos poderosos no sistema de mercado informal.

O sistema de privilégios parece ser o principal esquema que, através de um modelo comportamental e condicionador, produz uma reorganização do indivíduo. Além dele, temos o alívio de responsabilidades econômicas e sociais (superestimadas nos hospitais psiquiátricos), embora essa prática tenha um efeito mais desorganizador do que estruturante.

O processo de confraternização, no qual pessoas socialmente distantes desenvolvem entre si apoio mútuo e resistência a um sistema que as obrigou à intimidade numa única comunidade iguali- 
tária de destino, também é um elemento com poderosa influência reorganizadora. Os internados, na convivência, descobrem que todos têm qualidades de seres humanos comuns, ocasionalmente decentes, e são merecedores de simpatia e apoio. Os delitos prévios deixam de servir como parâmetro para o julgamento das qualidades pessoais. Acusados de crimes contra a sociedade, os internados em prisões, embora algumas vezes sejam inocentes, podem chegar a compartilhar os sentimentos de culpa dos companheiros, bem como as complexas defesas erguidas contra tais sentimentos.

A prisão parece produzir criminosos, pois os presos tendem a desenvolver um sentimento de injustiça comum e um ressentimento contra o mundo externo, decidindo se tornar criminosos, para se vingarem da culpa e da privação excessiva ou injusta a que foram submetidos no cárcere.

A "gozação" coletiva é outro ajustamento secundário que manifesta com clareza o processo de confraternização e a rejeição à equipe dirigente e seus auxiliares: a solidariedade dos internados pode ser suficientemente forte para apoiar gestos passageiros de desafio anônimo ou coletivo (gritar frases feitas, apelidos, vaias, aplausos diante de um incidente desagradável sofrido por um dirigente em meio a todos, batidas em pratos, mesas ou bandejas, rejeição coletiva ao alimento, pequenas sabotagens etc.).

A solidariedade pode unir de modo especial uma região fisicamente próxima, constituindo um território geográfico-afetivo: uma casa, um pavilhão, uma ala do prédio etc., cujos moradores se consideram como uma unidade administrativa singular, partilhando de um intenso sentimento de identidade e destino comum. A solidariedade no processo de confraternização também se desenvolve em unidades ainda menores, podendo constituir um tipo de grupo primário dentro do estabelecimento: "panelinhas", facções, ligações sexuais mais ou menos estáveis e a formação de pares (quando dois internados passam a ser reconhecidos como "amigos" ou "casal" pelos demais companheiros). As instituições totais lidam com esses pares de modo muito diverso. Tais relacionamentos podem ter um reconhecimento semioficial ou podem ser proibidos, encarados 
como incestuosos, sendo impedida a criação de um mundo próprio do casal no estabelecimento. A solidariedade pode também ser amplamente combatida, porque a união dos internados pode facilitar a combinação, em grupo, de atividades proibidas. É preciso observar que essas expressões de solidariedade são limitadas em razão das coerções que colocam os internados numa posição de identificação e comunicação precárias e, assim, não levam necessariamente a um alto moral de grupo solidário. Nos casos em que não se pode confiar nos companheiros, pois esses representam uma ameaça potencial permanente, podendo roubar, atacar ou delatar o indivíduo, ele pode experimentar a anomia.

\section{Estratégias adaptativas ao contexto institucional}

Vejamos quais são as estratégias de adaptação do indivíduo às condições ambientais da instituição total, mapeadas por Goffman (1987, p.58-63). O internado precisa se adaptar aos processos de admissão, mortificação e ao sistema de privilégios. Tal adaptação pode acontecer de vários modos e o internado empregará diferentes táticas adaptativas ao longo de sua "carreira moral", podendo também alternar entre diversas estratégias ao mesmo tempo. Vamos descrever, a seguir, as estratégias utilizadas como recursos adaptativos.

a) Afastamento da realidade: o internado aparentemente deixa de dar atenção a tudo, com exceção dos acontecimentos que cercam seu corpo e os vê a partir de uma perspectiva que não é compartilhada pelos demais internados. Trata-se de uma abstenção com graus variados de não participação em acontecimentos e interações. Esse afastamento pode ser visto como uma regressão, despersonalização ou alienação;

b) Intransigência: o internado desafia intencionalmente o estabelecimento ao negar-se, de modo visível, a cooperar com a equipe dirigente. Sua intransigência é constante e o indivíduo 
revela elevado moral. Mas, ao rejeitar abertamente o estabelecimento, o internado está permanentemente atento à sua organização formal, demonstrando um grau paradoxal de profunda participação na vida do estabelecimento. Por sua vez, os dirigentes podem pretender dobrar ou quebrar a vontade intransigente e a resistência do internado, por meio da solitária nas prisões e do tratamento com choques elétricos nos hospitais psiquiátricos, por exemplo. Desse modo, o estabelecimento mostra, com relação ao rebelde, uma devoção tão especial quanto a que esse dedicou ao estabelecimento. A rebeldia costuma ser uma forma de reação inicial e temporária, depois o internado se utiliza de outras táticas adaptativas;

c) Colonização: o indivíduo se adapta de tal modo ao estabelecimento, que nele acaba por encontrar um lar, acreditando e sentindo que vive no melhor dos mundos e nunca experimentou antes nada melhor. Ele passa a considerar o pouco do mundo externo que o estabelecimento oferece como se fosse o todo e procura construir uma existência estável e relativamente satisfatória, usufruindo o máximo possível do que lhe propicia a vida institucional. A colonização, que seria o objetivo oculto máximo da instituição e também do estabelecimento, dado o nível elevado de cooperação do internado, é paradoxalmente vista como um problema: a equipe dirigente pode ficar perturbada ao perceber que as possibilidades positivas da situação estão sendo mal empregadas. Os próprios colonizados podem sentir-se obrigados a negar sua satisfação, mesmo que seja apenas por razões de solidariedade aos seus companheiros. Podem ainda sabotar espontaneamente a própria saída, criando problemas ao se aproximar a data fixada para sair do estabelecimento e prolongando sua estada. Os esforços da equipe dirigente para melhorar as condições de vida no estabelecimento podem criar a possibilidade de aumentar a atração e a própria colonização;

d) Conversão: o internado parece aceitar a interpretação oficial da equipe dirigente e procura representar o papel do inter- 
nado perfeito. O convertido aceita uma tática disciplinada, moralista e monocromática, apresentando-se como alguém cujo entusiasmo pelo estabelecimento está sempre à disposição da equipe dirigente;

e) "Se virar": as táticas anteriores representam comportamentos coerentes que podem ser seguidos, mas os internados não perseveram nelas por muito tempo. Eles acabam "se virando" e utilizam um "jogo de cintura": uma combinação oportunista de ajustamentos secundários, conversão, colonização e lealdade aos colegas, de modo a obter, dentro da situação específica, uma possibilidade máxima de evitar sofrimentos físicos ou psicológicos.

\section{A especificidade da dinâmica cultural dos internados}

Além disso, a perspicácia de Goffman (1987, p.63-6) o levou a prestar atenção e a destacar outros aspectos do mundo cultural específico do internado numa instituição total: autopiedade, noção do tempo, valor das distrações. As instituições totais produzem em seus internados um tipo e um nível de preocupações pessoais características. O internado é colocado numa posição social inferiorizada comparativamente à que ocupava no mundo exterior, sob a ação dos processos de mortificação e de despojamento ao quais é submetido. Isso cria nele uma sensação constante de fracasso pessoal e de desgraça. Como reação a esse sentimento, o internado costuma criar uma "história pessoal" que funciona como um conto triste, num estilo de lamentação e defesa, elaborando sua versão para explicar sua situação de inferioridade atual. Ele conta sua história aos companheiros em tom de autopiedade. Os colegas tendem a ouvi-lo com condescendência e a equipe dirigente costuma desmenti-lo.

Outra característica é que, entre os internados de muitas instituições totais, existe uma forte sensação de que o tempo de internação é inútil, perdido, roubado de sua vida, tempo que precisa ser apagado, cumprido, preenchido ou arrastado de algum modo. 
Durante sua estada obrigatória, o internado costuma sentir que esteve completamente exilado da vida. Isso indica que internações excessivamente prolongadas têm um efeito proporcionalmente desmoralizador. Condições precárias de vida, perda de contatos sociais, impossibilidade de adquirir dinheiro, formações de relações conjugais e ausência de certidão de estudos são outros elementos que explicam essa sensação de tempo perdido no estabelecimento.

Daí advém o significativo valor das atividades de distração nesses estabelecimentos, sejam individuais ou coletivas: jogos ao ar livre, bailes, festas, banda de música, coral, teatro, aulas, ateliês de arte, trabalhos manuais, televisão, filmes, jogos de cartas, homossexualidade, álcool, drogas que possibilitam "viagens". Essas e outras atividades de entretenimento ajudam o indivíduo a relaxar, aliviando um pouco a tensão produzida pelos ataques constantes à sua pessoa.

\section{As dificuldades do processo de reinserção social}

Vejamos como Goffman (1987, p.66-9) analisa alguns problemas típicos durante o processo de reinserção do internado na vida civil. Se e quando o internado é enviado de volta à sociedade mais ampla, ele pode experimentar algumas dificuldades, tais como a angústia, o estigma e a desaculturação.

Para os que estão internados, a vida no mundo externo é seu sonho mais precioso e seu desejo se chama liberdade. Mas, paradoxalmente, a proximidade da saída do estabelecimento cria angústia e muitos podem provocar a continuidade da internação para evitar o problema. O temor é criado pela questão: "Será que vou conseguir me virar no mundo?”. A sociedade civil apresenta uma face desafiadora diante de um indivíduo altamente desmoralizado. Muitos internados deixam aberta a possibilidade de regressar ao estabelecimento.

Embora as instituições totais tenham como objetivo a reforma e a reabilitação (pelas quais o indivíduo recuperaria os mecanis- 
mos autorreguladores supostamente perdidos) e pretendam que ele mantenha de modo espontâneo os padrões nos quais foi reeducado e ressocializado no estabelecimento, isso não costuma ocorrer exatamente assim.

Na prática, raramente essa mudança acontece. As alterações permanentes que realmente costumam ocorrer não são as desejadas pela equipe dirigente. Exceto no caso de algumas instituições religiosas, os processos de despojamento e de reorganização não parecem produzir um efeito duradouro. $\mathrm{O}$ indivíduo se defendeu da "reforma" imposta mediante ajustamentos secundários, nos quais se habituou a costumes contrários aos impostos pelo estabelecimento, além de se valer da estratégia de "dançar conforme a música".

A recuperação da liberdade pode deixar deslumbrado o ex-internado, maravilhado diante das possibilidades, escolhas, decisões e prazeres do status civil normal e cotidiano. Do mesmo modo, ele tende a se esquecer da dureza da vida de privações no estabelecimento e logo começa a aceitar novamente como indiscutíveis seus direitos e privilégios, em torno dos quais organizava sua vida no ambiente institucional. Os sentimentos de amargura, injustiça e alienação também costumam diminuir após a libertação.

O indivíduo percebe que a instituição total pela qual passou, deixou marcas indeléveis em sua vida. Quando ingressou no estabelecimento, seu status intramuros tornou-se radicalmente distinto do que era fora e se, e quando, sair, ele compreende que sua posição no mundo externo nunca mais será igual à anterior ao ingresso.

Dependendo do estabelecimento onde esteve internado, essa marca pode causar-lhe um certo orgulho (escolas de elite, religiosas e militares) ou podem representar um estigma, que precisa ser disfarçado e ocultado (prisões, hospitais psiquiátricos).

A angústia no tempo da reinserção parece ser produzida principalmente pela desaculturação, que pode se entendida como a perda ou impossibilidade de adquirir os hábitos atualmente exigidos na sociedade. A recepção do ex-internado pode ser fria e o estigma pode dificultar-lhe a tarefa de arrumar um emprego ou um lugar 
para viver. Geralmente, a libertação costuma ocorrer quando o indivíduo já domina sua vida no ambiente institucional, que se lhe tornou conhecido e ao qual ele se adaptou de algum modo, conseguindo alguns privilégios, dos quais aprendeu, dolorosamente, o alto valor desses. Assim, o ex-internado pode descobrir que ser livre significa passar do topo de um pequeno mundo, já familiar, para o ponto mais baixo de uma sociedade ampla, provavelmente fria, indiferente e hostil.

\section{O mundo da equipe dirigente}

Apresentamos, a seguir, os aspectos característicos do "mundo" da equipe dirigente de um estabelecimento total (Goffman, 1987, p.69ss.).

De um modo geral, as instituições totais funcionam como um depósito de internados, mas elas se apresentam ao público como organizações racionais, planejadas de modo consciente como máquinas eficientes para atingir determinados objetivos e capazes de cumprir certas finalidades oficialmente declaradas. Um de seus objetivos oficiais mais amplos e frequentes é a reeducação dos internados na direção de algum padrão ideal. São verdadeiras máquinas de sobrecodificação da subjetividade. A contradição entre os objetivos oficiais confessados e aquilo que o estabelecimento realmente produz constitui-se no contexto básico do trabalho cotidiano da equipe dirigente.

De acordo com Goffman (1987, p.70), o material de trabalho da equipe dirigente constitui-se de elementos humanos e a sua tarefa se reduz à administração, gerenciamento e controle de pessoas. Como material de trabalho, as pessoas podem também ser reduzidas às características de objetos inanimados, podendo ser vistas apenas em seus aspectos físicos. $\mathrm{O}$ indivíduo é etiquetado como um produto, numerado, encaixado numa nosografia, inscrito e descrito em relatórios e prontuários que dizem o que foi feito por ele, com ele e quais foram os responsáveis. Seu registro de caso vai crescendo 
à medida que vão sendo acrescentados notas e pareceres da equipe dirigente. As instituições totais mantêm padrões tecnicamente desnecessários de tratamento em seus cuidados com o material humano. Elas se sentem responsáveis pelos indivíduos e procura manter padrões humanitários com relação aos internados, como uma garantia que lhes oferecem em troca de sua liberdade.

A equipe dirigente deve levar em consideração o status e as relações sociais do internado no mundo externo, segundo Goffman (1987, p.71). Os internados costumam ter um status e relações no mundo externo e o estabelecimento institucional precisa respeitar alguns dos direitos dos internados como pessoas. É preciso dar conta de uma papelada burocrática que exige a interdição de um indivíduo internado num hospital psiquiátrico e a transferência de seus direitos e deveres para a tutela de outra pessoa, que se torna responsável e representante legal do mesmo. É preciso administrar as relações eventuais do internado com a sociedade: benefícios da previdência social, imposto de renda, manutenção de propriedades, seguros, pensões, contas pendentes etc. Várias agências da sociedade e os parentes do internado lembram à equipe dirigente de suas obrigações quanto aos padrões humanitários e direitos do indivíduo. Os próprios internados podem desempenhar bem esse papel.

\section{Problemas de governo da instituição total}

Existem ainda certos "problemas de governante" que devem ser enfrentados pela equipe dirigente (Goffman, 1987, p.72ss.). As instituições totais funcionam mais ou menos como um estado e sua equipe dirigente tem que enfrentar problemas de um modo parecido aos que têm os governantes de Estados, deparando com dilemas clássicos, como conflitos entre meios e fins, manutenção de padrões humanitários versus eficiência institucional, esforços para evitar fugas, esconder decisões quanto ao destino dos internados, distância versus afeição pelos internados e outras dificuldades específicas no trabalho com pessoas. 
A garantia de padrões em benefício de um internado pode exigir o sacrifício desses mesmos padrões, dificultando o discernimento dos meios para atingir esse fim. Sobretudo nos casos em que o próprio internado prejudica a si mesmo, danificando de algum modo o próprio corpo, ferindo-se, recusando alimentos, exigindo por isso, restrições por parte da equipe dirigente.

Os bens pessoais são parte de um território egoico importante. Mas eles dificultam a eficiência institucional e são restringidos ou proibidos. O conflito costuma ser resolvido em favor da eficiência: as cabeças raspadas ficam limpas de piolhos, apesar do dano causado à aparência pessoal. Pacientes com mania de morder podem ter seus dentes extraídos, mulheres com tendência para a promiscuidade sexual podem ser submetidas a histerectomias, briguentos crônicos, à lobotomia etc. Se o internado tem o direito de fazer visitas fora do estabelecimento, muitas instituições restringem essa possibilidade, pois o estabelecimento tem responsabilidade nos erros que ele possa vir a cometer.

As pessoas, diferentemente de outro material de trabalho, podem receber instruções e executá-las sozinhas, mediante o uso de ameaça, prêmio ou persuasão. Mas, se os internados têm capacidade para perceber e seguir os planos da equipe dirigente, também podem opor-se efetivamente a esses. A equipe dirigente deve estar preparada para evitar os esforços organizados para fugas e tentativas de enganá-la ou de dirigi-la.

Por mais distante que a equipe dirigente procure manter-se desse material humano, esse sempre pode tornar-se objeto de camaradagem e de afeto, o que dificultaria a imposição de um tratamento considerado cruel, causando sofrimento na equipe dirigente. Caso ela considere o internado como um ser humano, pode sentir-se mortificada, humilhada e desafiada quando o internado não reage de modo adequado.

A relação de afeto e ligação emocional entre membros da equipe dirigente e internados acontecem mediante um fenômeno denominado ciclo de participação. Uma pessoa pode descobrir que não tem razão para não estabelecer relações afetuosas com alguns 
internados. Mas tal relacionamento torna o indivíduo da equipe dirigente vulnerável às ações e sofrimentos dos internados, em sua aproximação, ficando numa situação em que tende a ameaçar a posição e a postura distante de seus colegas de equipe. A pessoa que criou vínculos com os internados pode se sentir "queimada" e ser transferida para trabalhos burocráticos longe dos internados. Afastada da possibilidade perigosa de contato com os internados, o profissional diminui sua cautela e o ciclo de contato e afastamento pode repetir-se indefinidamente.

A obrigação de manter padrões humanitários de tratamento e a relação emocional com os internados provoca problemas e dificuldades específicas para a equipe dirigente em seu trabalho com pessoas: lidar com pessoas que, de maneira clara, agem contrariamente ao que seria melhor para si mesmas, exige esforços que devem frustrar os atos visivelmente autodestrutivos. A equipe dirigente pode ser obrigada a "maltratar", de modo duro e autoritário, tais indivíduos. Essa situação conflitiva cria dificuldades para o controle emocional da equipe dirigente.

\section{O manejo do discurso e a prática oficial no estabelecimento}

Goffman (1987, p.77ss.) esclarece que a equipe dirigente do estabelecimento apresenta e representa a perspectiva oficial da instituição. A rotina da equipe dirigente é estruturada em torno das exigências especiais do trabalho com pessoas e é realizada num clima moral específico: ela enfrenta a hostilidade e exigências dos internados e precisa apresentar a eles a perspectiva racional defendida pelo estabelecimento. Os objetivos das instituições totais podem ser: realização de algum objetivo econômico, educacional, instrução, tratamento médico ou psiquiátrico, purificação religiosa e proteção da comunidade mais ampla. Mas elas, muitas vezes, ficam longe de suas metas oficiais. 
O esquema de interpretação de uma instituição total entra em funcionamento automático quando há a admissão do internado, tomada como uma prova concreta de que é com um indivíduo assim que o estabelecimento trabalha. Esse é o centro de um meio básico de controle social.

Os internados, quando podem, fazem pedidos e a equipe dirigente apresenta justificações ideológicas para a imposição de restrições. Assim, a equipe dirigente controla os internados e defende o estabelecimento e a instituição em nome de seus objetivos confessados. Os castigos e privilégios que ela distribui são apresentados numa linguagem que expressa essas metas oficiais.

Cada perspectiva institucional contém uma moralidade pessoal. Os internados devem ser conduzidos a auto-orientação controlável e as condutas desejáveis e indesejáveis precisam ser definidas como decorrentes da vontade pessoal deles, entendidas como algo que se pode controlar.

Desse modo, a equipe dirigente tende a criar uma "teoria sobre a natureza humana” (Goffman, 1987, p.80), que racionaliza sua atividade, estabelece e mantém a distância social com o internado, dá uma interpretação estereotipada dele e justifica o tratamento que lhe é imposto. Essa teoria geralmente abrange as possibilidades adequadas e irregulares de conduta do internado, o valor institucional de privilégios e castigos e também a diferença essencial entre a equipe dirigente e o grupo dos internados.

A teoria sobre a natureza humana desenvolvida no ambiente institucional costuma considerar o ser humano como um ser fraco. Para lidar com ele, é preciso lançar mão de soluções intermediárias, mostrar consideração e utilizar medidas de proteção. O estabelecimento deve garantir certos padrões de bem-estar acima daqueles exigidos para a simples sobrevivência, pois um ser humano é algo mais do que apenas um participante do estabelecimento. $\mathrm{O}$ indivíduo pode colaborar voluntariamente com a organização da qual participa, por meio de interesses comuns partilhados por ambos. Pode ser necessário utilizar prêmios e incentivos que levem o indivíduo a colaborar quando seus objetivos não coincidem com os 
do estabelecimento institucional. Os participantes também podem ser estimulados a colaborar, induzidos por ameaças e castigos: as sanções negativas incluem uma redução nos prêmios ou nos níveis usuais de bem-estar. $\mathrm{O}$ medo do castigo é adequado para impedir que o indivíduo realize ou deixe de realizar determinados atos. Mas reforços positivos tais como prêmios parecem necessários para que se obtenha um esforço prolongado, contínuo e pessoal. A noção de que os indivíduos respondem aos castigos ou prêmios como meios para produzir a resposta esperada exige suposições diferentes relativas ao que seja a natureza humana. Portanto, a organização total não se limita a utilizar a atividade de seus participantes, mas ela também delineia os padrões oficiais adequados de bem-estar, valores conjuntos, incentivos e castigos. A própria ação da equipe dirigente ou da administração exprime a concepção que ela tem dos indivíduos sobre os quais atua. Boa parte dos conflitos entre os dois grupos antagônicos diz respeito à concepção da natureza, ao papel imposto aos internados e às diferentes reações deles ao caráter presumido pelos dirigentes.

A instituição é uma estrutura abstrata que cria suposições de papéis e identidades sociais. Quando o indivíduo participa de determinada atividade do estabelecimento com o ânimo e disposição que se espera dele, está aceitando implicitamente que é um determinado tipo de pessoa vivendo num mundo específico. Toda instituição e todo estabelecimento, além de uma disciplina de atividade, incluem ainda uma constituição subjetiva específica, modelando o ser do indivíduo, impondo-lhe um determinado caráter e um ambiente específico onde deve manifestá-lo. Esse ser prescrito e as suposições a respeito do "eu" costumam ser sistematicamente enfrentadas pelos participantes internados mediante diferentes estratégias de adaptação e, sobretudo, por meio dos ajustamentos secundários. Agir e ser, nesse caso, estão longe de ser equivalentes.

O trabalho é um outro elemento reinterpretado pelas perspectivas institucionais. Se no mundo externo ele é realizado para conseguir pagamento, lucro, prestígio, no estabelecimento ele pode ser redefinido como "terapia ocupacional", por exemplo, afirmando- 
-se ao internado que sua realização faz parte do tratamento. As instituições religiosas também apresentam reinterpretações semelhantes para justificar a realização de trabalhos pelos internados.

As instituições totais geralmente contratam especialistas para auxiliar no cuidado e controle dos internados. Desse modo, não precisam mandar os internados para fora do estabelecimento. Os especialistas costumam ficar insatisfeitos com sua participação institucional, pois se sentem impedidos de exercer corretamente sua profissão, além de serem usados como cativos para dar sanção de especialistas ao sistema de privilégios. Também são um grupo em conflito com os objetivos oficiais da instituição.

\section{Os cerimoniais institucionais}

Outro elemento estrutural das instituições totais, analisado por Goffman (1987, p.84-98), é composto pelos "cerimoniais institucionais". A distância e as diferenças entre os grupos de dirigentes e internados podem diminuir ou variar em algumas circunstâncias específicas. Geralmente, a imagem que um grupo tem do outro não leva a uma identificação, exceto no caso de internados que aceitam um papel de confiança e passam a desempenhar um cargo nomeado pela equipe dirigente, numa função auxiliar, num processo de "identificação com o agressor". Quando ocorrem relações de intimidade entre os dois lados, há uma tendência para a subversão da autoridade, seguem-se os ciclos de participação, reinstaura-se a distância social, como se fosse o tabu do incesto agindo na vida institucional.

A dificuldade em manter essa segregação de papéis sociais também aparece quando os internados realizam serviços inferiores para a equipe dirigente: pintura de casas, limpeza, jardinagem etc. A equipe dirigente é, assim, obrigada a ter certa consideração com seus "empregados" e não consegue manter a distância usual com relação aos mesmos.

Outra forma de cruzar a fronteira entre os dois grupos é estabelecida pelos "cerimoniais institucionais". Trata-se de práticas 
institucionalizadas que exprimem solidariedade, unidade e compromisso conjunto de todo o estabelecimento, produzindo-se maior aproximação entre os dois grupos, possibilitando que ambos tenham uma visão mais positiva um do outro e se identifiquem com a situação alheia. Nesses cerimoniais institucionais, há uma liberação das formalidades, dos papéis estereotipados, da usual distância entre a equipe dirigente e os internados e a participação pode ser relativamente voluntária.

Um “órgão de divulgação", como um jornal ou uma revista produzidos periodicamente, é um dos elementos que compõem o "cerimonial institucional". Os internados são colaboradores e a censura e a supervisão costumam ser exercidas por alguém que se relacione bem com os internados. A publicação trata da vida da instituição e do seu estabelecimento, dando-lhes um caráter de realidade pública ao mundo externo. Esses boletins sobrevivem numa situação delicada e de equilíbrio instável, pois servem de veículo de expressão para dois grupos antagônicos.

Outro tipo de "cerimonial institucional" é a "festa anual do estabelecimento", na qual os dois grupos se misturam mediante formas padronizadas de sociabilidade: comem juntos, participam de jogos de salão, de bailes, tomam liberdades uns com os outros, inclusive de caráter sexual. Os papéis podem se inverter e a equipe dirigente pode se colocar a servir os internados. Isso pode ocorrer na comemoração do aniversário do estabelecimento ou em datas significativas como o Natal, por exemplo.

O "teatro institucional" é outra cerimônia institucional. Os diretores podem ser da equipe dirigente e os atores, do grupo dos internados. Há ainda a opção de elencos mistos. Os autores podem ser de um dos dois grupos e a peça costuma ser carregada de referências locais, satirizando comportamentos de pessoas da equipe dirigente de alto escalão ou situações do seu cotidiano. Caso o estabelecimento institucional seja composto de pessoas do mesmo sexo, alguns dos atores podem representar com roupas e papéis burlescos do outro sexo. O humor grosseiro muitas vezes coloca à prova os limites da liberdade. A plateia é constituída por pessoas dos dois 
grupos e convidados. Um grande público estranho dá ao grupo dos dirigentes e à equipe dirigente um fundo contrastante que aumenta sua sensação de unidade.

Outra prática do "cerimonial institucional" é a abertura dos portões, uma vez por ano, para a visita dos parentes dos internados e do público em geral. O público pode apreciar a manutenção de elevados padrões humanitários e notar relações que parecem visivelmente cordiais entre os dois grupos do estabelecimento. Isso exige uma série de reduções das restrições costumeiras.

A prática dos portões abertos se dá no contexto de uma "exibição institucional”, dirigida para visitantes em geral, com o intuito de transmitir uma imagem adequada do estabelecimento, calculada para reduzir um vago temor de instituições involuntárias. Mas o que se exibe são apenas os melhores locais e os internados mais cooperadores e serviçais.

$\mathrm{O}$ visitante pode ser alguém que faça a ligação entre o estabelecimento e o alto escalão responsável pela fiscalização e controle de toda uma categoria de instituições. Nesse caso, a preparação da exibição é complexa: limpeza, arrumação, decoração, vestimenta melhor para os internados, refeições especiais etc. As visitas geralmente fazem que todos no estabelecimento se lembrem que não vivem num mundo inteiramente isolado e existem vínculos burocráticos e hierárquicos com estruturas do mundo mais amplo.

A exibição institucional também costuma dar aos internados a impressão de que vivem na melhor das instituições dessa natureza, idealizando o estabelecimento no qual vivem. Essa crença é reforçada pelos vínculos de unidade e de identificação entre internados e dirigentes quando estão diante do público, com a sensação de possuir um status no mundo social externo. Mas isso se dá à custa de sua segregação dessa mesma realidade social externa.

A parte do estabelecimento que costuma ser exibida costuma ser a mais nova e atualizada. A exibição pode acentuar objetos utilitários, como equipamentos de cozinha, de lavanderia, de cirurgia, informática, biblioteca etc. A função de exibição desse equipamento pode ser parte da motivação para adquiri-lo. A exibição de 
fotografias, que retratam os procedimentos pelos quais os internados passam durante seu tratamento, de murais pintados pelos internados e o alimento especial servido no dia da inspeção têm necessariamente consequências concretas, mas não se comparam com a impressão muito maior que cada item causa numa exibição.

A dinâmica de aparências ultrapassa o simples contraste entre apresentação e realidade. Existe uma realidade que é escondida dos internados, uma que lhes é revelada e uma que é apresentada aos visitantes. Em muitas instituições totais, existem castigos não previstos pelo regulamento, aplicados numa cela ou em algum lugar distante da maioria dos internados e da equipe dirigente. Esses castigos secretos não são frequentes, mas ocorrem de modo estruturado, como consequência prevista ou suposta de alguns tipos de transgressão. Tais acontecimentos são, para a vida diária do estabelecimento, o que a vida diária é para a exibição apresentada para visitantes.

A "sala de visitas" é um instrumento importante dentro do "cerimonial institucional": sua decoração e o comportamento ali expresso são usualmente mais próximos dos padrões externos do que os predominantes nos ambientes nos quais os internados realmente vivem. O que os estranhos veem na sala de visitas ajuda a minimizar a pressão que poderiam fazer contra a realidade do estabelecimento, que fica mascarada pelo verniz social enganador. Com o tempo, tanto o visitante quanto o internado e a equipe dirigente compreendem que a "sala de visitas" é uma representação maquiada da vida institucional. Todos sabem que os demais já entenderam isso e concordam tacitamente em continuar no plano da ficção.

O estabelecimento pode ainda realizar um acordo com artistas amadores, ex-profissionais ou voluntários, organizando "apresentações gratuitas ou de caridade”. O estabelecimento fornece o palco e uma audiência favorável e os atores contribuem com uma representação gratuita. Os eventos dão aos artistas a impressão de estarem diante de internados e uma equipe dirigente que convivem harmoniosamente e que desfrutam de uma noite voluntária de recreação não imposta. 
Os "esportes internos" são outro elemento do "cerimonial institucional”. A equipe da casa costuma ser um time de craques escolhidos por disputa entre todos os internados. Numa competição com uma equipe externa, os craques desempenham papéis que fogem do estereótipo usual do internado: no esporte coletivo, demonstram habilidades, perseverança, inteligência, cooperação e fibra. Tais papéis são interpretados diante dos estranhos e da equipe dirigente. A equipe visitante e a torcida que a acompanha podem ver que as coisas correm normalmente no estabelecimento. Os esportistas, ao realizarem uma atividade considerada espontânea, demonstram que a equipe dirigente, nesse ambiente pelo menos, não é tirânica e que eles são autorizados a assumir o papel de representantes do estabelecimento (vestem a camisa da casa). O mesmo faz a equipe dirigente, ao torcer pelo time da casa. Além de dar instruções relativas ao esporte, ocasionalmente participa dos jogos, eliminando as diferenças sociais estabelecidas entre os dois grupos.

Os "papéis sociais" se evidenciam na instituição total quando se realizam os "cerimoniais institucionais". Em todos os casos de vida cerimonial unificada, a equipe dirigente costuma representar mais do que o papel de supervisão. Muitas vezes, um funcionário de alto nível está presente como um símbolo da administração e de todo o estabelecimento. Ele geralmente se veste bem, fica comovido com a cerimônia, sorri, faz discursos, dá parabéns, inaugura novas instalações, "abençoa" novos equipamentos, julga as disputas e distribui prêmios. Nessa atuação, desempenha uma interação benigna e demonstra interesse paternal pelos internados e esses costumam demonstrar acanhamento, deferência e respeito. Isso é muito parecido com a representação de um senhor feudal desempenhando seu papel na festa anual em seu feudo, em plena sociedade moderna.

As "cerimônias institucionais" tendem a ocorrer dentro de uma certa periodicidade espaçada, despertam alguma excitação social, todos os grupos do estabelecimento participam, independentemente de posto ou posição, mas recebem um lugar que exprime sua posição. Uma sociedade perigosamente dividida entre internados e equipe dirigente pode ser unida por meio de tais cerimônias. 
Mas pode haver indícios ou mesmo início de rebeldia no papel que os internados desempenham em tais cerimônias: uma cena satírica no teatro, um artigo ácido no periódico do estabelecimento, uma disputa mais acirrada num jogo do qual participam membros da equipe dirigente, excessiva liberdade e familiaridade durante uma festa. Essas são possibilidades de profanar o superior. A tolerância dessa falta de respeito é sinal da força da direção do estabelecimento. A exteriorização de conflitos, diretamente, por inversão ou por outras formas simbólicas, acentua a coesão social dentro da qual existe o conflito. Exprimir rebeldia diante de autoridades, num momento em que é adequado fazê-lo, é trocar a conspiração pela expressão.

Geralmente a equipe dirigente se queixa de tédio por ter que participar de tais cerimônias e o faz por considerar que noblesse oblige ou por temor dos superiores. Os internados participam por causa do conforto e da suspensão das restrições, para ficar bem diante da equipe dirigente e talvez conseguir a liberdade mais depressa.

Uma instituição total precisa de cerimônias coletivas porque o estabelecimento é algo mais do que apenas uma organização formal; no entanto, essas cerimônias podem ser "forçadas" e insípidas, porque o estabelecimento é algo menos do que uma comunidade.

Os estabelecimentos totais de qualquer tipo definem seus membros a partir de alguns traços e de algumas qualidades essenciais de caráter, que apresentam diferenças radicais, dependendo do fato de a pessoa se localizar na equipe dirigente ou entre os internados. O papel de dirigente e o de internado abrange todos os aspectos da vida. Mas essas duas caracterizações antagônicas precisam ser desempenhadas por civis que já foram profundamente instruídos em outros papéis e outras possibilidades de relações.

Quanto mais o estabelecimento reforça a suposição de que os dois grupos são compostos por seres humanos diferentes, proibindo a relação informal entre ambos e quanto mais profunda for essa separação dramática, mais incompatível essa representação social se torna com relação ao repertório civil dos atores, e mais vulnerável a eles. Essas diferenças supostas entre dirigentes e internados não 
são inevitáveis nem inalteráveis. São comuns anedotas de identidade, nas quais internados e dirigentes são confundidos e trocados uns com outros.

\section{Outros aspectos gerais das instituições totais}

De modo meticuloso, Goffman (1987, p.99-108) ainda indica uma série de outros aspectos gerais das instituições totais. Há diferenças intragrupais relevantes que devem ser consideradas. A equipe dirigente e os internados não constituem dois grupos homogêneos. No estudo das instituições totais é importante saber qual a diferenciação típica de papéis dentro de cada um dos grupos principais. Geralmente existem diferenças no interior dessas duas categorias que devem ser consideradas.

Dentro da equipe dirigente alguém é responsável pela representação do estabelecimento nos conselhos da sociedade mais ampla e esse indivíduo precisa desenvolver aptidões não institucionais para desempenhar seu papel com eficácia. Outro membro deverá lidar com visitantes e com os vínculos externos dos internados, numa tarefa de relações públicas. Pode ser que até mesmo um indivíduo da equipe dirigente precise representar um símbolo pessoal da instituição e do estabelecimento para os internados, tornando-se um objeto de projeção de diferentes emoções desses.

No nível mais baixo da equipe dirigente é comum encontrar um grupo formado por empregados de longa data no estabelecimento, responsável pela transmissão da tradição do estabelecimento. Já o grupo de nível mais elevado, e incluindo os internados, pode apresentar elevados índices de rotatividade. $\mathrm{O}$ grupo de nível mais baixo é aquele que precisa apresentar, pessoalmente, as exigências do estabelecimento aos internados. Por isso, são vítimas do ódio dos internados, enquanto o grupo dirigente de alto nível fica livre dessa projeção e se permite tratar os internados com bondade paternal e benevolência, em poucos contatos com eles, sem prejuízo da disciplina geral. Os internados tendem a sentir-se seguros ao percebe- 
rem, mesmo que ilusoriamente, que, embora a maioria da equipe dirigente seja má, o indivíduo que ocupa o posto mais elevado é bom, ainda que possa ser enganado pelos seus inferiores. Em termos de poder real, pode acontecer que o homem forte do estabelecimento esteja no nível mais baixo da equipe dirigente, se tomarmos como referência sua função e suas prerrogativas. $\mathrm{O}$ homem de posto mais elevado no estrato mais baixo pode ter mais poder e autoridade do que o homem de posto mais baixo no estrato mais elevado.

Há também variação na diversidade de papéis da equipe dirigente e entre os internados. As instituições totais variam consideravelmente quanto à quantidade, qualidade e nitidez na diferenciação de papéis designados para serem exercidos pela equipe dirigente e os supostos papéis para o grupo dos internados. Em certas instituições religiosas, como nos conventos, todos os membros da comunidade, tanto dirigentes quanto dirigidos, podem ser obrigados a participar de algumas privações básicas. Todos podem ter os mesmos tipos de acomodações, independentemente de qualquer outra distinção. Para alguns conventos, a noção de uma divisão em dois grupos (equipe dirigente e internados) não parece produtiva. Essas instituições se organizam num único grupo colegial, internamente estratificado em razão de uma ordem de postos sutilmente graduados. Com relação aos colégios internos, é útil acrescentar aos estratos de professores e alunos um terceiro grupo: o encarregado dos serviços domésticos.

O modo de recrutamento varia nas instituições totais. Os novatos ingressam com diferentes estados de ânimo. O espectro vai do absolutamente voluntário, passa pelo semivoluntário, até o involuntário. Como exemplo do recrutamento voluntário, temos as instituições religiosas, nas quais os indivíduos ingressam por livre e espontânea vontade. Esses estabelecimentos lidam apenas com aqueles que se consideram chamados e os dirigentes escolhem os candidatos que julgam mais adequados e sérios em suas intenções. Neste último caso, a conversão já parece ter ocorrido e a tarefa se resume apenas em indicar ao novato (aspirante, noviço) as maneiras pelas quais pode atingir autodisciplina. 
O exército representa um tipo de instituição na qual o recrutamento pode ser considerado semivoluntário. Nele, os internados são obrigados a servir e têm muitas oportunidades para compreender que esse trabalho é justificável e pode ser exigido em razão de seus interesses finais. Entradas inteiramente involuntárias acontecem nos casos de internação num hospital psiquiátrico, reclusão na prisão e incorporação forçada à tripulação de um navio. Neste último caso, os internados oferecem maior resistência ao perfil que a equipe dirigente quer lhes impingir.

Há ainda variação de exigências quanto ao grau de modificação interna do indivíduo. O grau de mudança interior do internado que é explicitamente desejado pela equipe dirigente também varia, de acordo com os diferentes tipos de instituições e suas finalidades. Nas instituições de custódia e de trabalho, o internado precisa apenas obedecer às ações padronizadas e seu estado de ânimo e sentimentos íntimos não são preocupação oficial. Já nos campos de "lavagem cerebral", nas instituições religiosas e nas de tratamento mental, os sentimentos íntimos do internado são altamente considerados e constantemente monitorados mediante diferentes técnicas. Eles devem aceitar ativamente os padrões da equipe dirigente. A permeabilidade à influência da sociedade-ambiente nos padrões sociais institucionais também varia. Quanto maior o grau de influência mútua entre a instituição e a sociedade, mais suas diferenças se reduzem.

$\mathrm{Na}$ análise do processo de admissão nas instituições totais, os aspectos impermeáveis do estabelecimento se realçam. O novato sofre um processo de despojamento e nivelamento nesse momento, perdendo as várias distinções sociais, como riqueza, status social, diferenças de idade, inclusive o nome etc. Um certo nível de impermeabilidade parece ser necessário para a manutenção da moral e do equilíbrio do estabelecimento institucional. Paradoxalmente, ao suprimirem as distinções sociais externamente válidas, a instituição total mais radical pode ser também a mais democrática. Mas as instituições totais precisarão empregar necessariamente algumas distinções sociais já estabelecidas na sociedade mais ampla, ainda que 
isso ocorra apenas para realizar as tarefas indispensáveis relativas à sociedade e ser por ela tolerada.

Outra diferença entre as instituições totais se verifica no destino social de seus egressos. Temos o caso daqueles que têm suas vidas radicalmente determinadas por sua participação original em certo estabelecimento, como membros de abadias beneditinas e ex-prisioneiros, que depois de sua passagem pela prisão podem orientar suas ocupações futuras para o ambiente do submundo social. Soldados desmobilizados na reserva podem ausentar-se definitivamente do regimento. Ex-doentes mentais podem evitar cuidadosamente qualquer coisa ou atividade que possam relacioná-los com o hospital. Entre esses dois extremos, temos o sistema dos "amigos de turma”, que mantém vínculos festivos com as instituições, típico de escolas e universidades particulares. Os egressos se reúnem eventualmente para comemorar sua passagem pelo estabelecimento.

Depois de definir as instituições totais e enumerar suas características gerais, podemos concluir, apontando para suas semelhanças, que se impõem de modo persistente e decisivo, obrigando-nos a considerar a especificidade desse fenômeno social. Assim, instituições tais como prisões, hospitais psiquiátricos, colégios internos, conventos, seminários para formação de padres e instituições religiosas em geral têm muitos aspectos em comum, fato que não parece tão evidente num primeiro momento. Essa estruturação característica dos estabelecimentos totais parece funcionar de modo autônomo, e abades, reitores, diretores, comandantes, guardas, superiores, enfermeiros, médicos e psiquiatras não deveriam ser condenados por sua responsabilidade pessoal, nem elogiados por seus talentos administrativos. Somente poderemos compreender os problemas sociais, e o impacto produzido na subjetividade, criados pelas instituições totais, mediante o estudo da estrutura social subjacente a esses estabelecimentos. 


\section{3 \\ FOUCAULT E A PRISÃO COMO MODELO INSTITUCIONAL DA SOCIEDADE DISCIPLINAR}

Já apresentamos alguns aspectos do pensamento foucaultiano em outras publicações (Benelli; Costa-Rosa, 2003a; Benelli, 2004a, 2006), demonstrando como o quadro histórico que Foucault traça da sociedade moderna e contemporânea se constitui em importante ferramenta para realizarmos análises institucionais, juntamente com Goffman.

O que nos ocupa nesta pesquisa é a análise de instituições entendidas enquanto elementos de um dispositivo articulador das relações entre produção de saberes e modos de exercício do poder. Por isso retomamos a descrição de determinadas instituições: aquelas que, num dado momento histórico, constituem peças na engrenagem de um tipo específico de sociedade, que Foucault (1984, 1999b) nomeou como "instituições disciplinares". Nesse sentido, o que a genealogia de Foucault nos proporciona é uma análise pragmática da nossa situação atual, haja vista que ainda vivemos numa sociedade disciplinar. (Benelli, 2006, p.63)

A hipótese da sociedade disciplinar é um importante pano de fundo sócio-histórico que nos permite entender como são possíveis as instituições totalitárias e disciplinares na contemporaneidade, 
muito embora elas pudessem ser consideradas ultrapassadas, em razão do avanço tecnológico das diversas estratégias de controle e vigilância, sobretudo com a revolução da informática.

Foucault (1999b, p.141) sintetiza a produção que o poder disciplinar efetua a partir dos corpos que controla: as individualidades são caracterizadas como celular (por meio do jogo da repartição espacial); orgânica (pois codifica formalmente as atividades); genética (ao acumular um tempo segmentado e serializado) e combinatória (pela composição das forças).

A tecnologia disciplinar, aperfeiçoada sobretudo a partir da matriz conventual (Benelli, 2004b), tende a atravessar as diversas instituições que compõem o corpo social, incidindo num nível propriamente capilar e microfísico do tecido social. Pelo processo descrito aqui, o poder disciplinar constrói uma sociedade disciplinar, adestrando e produzindo coletivamente corpos individualizados e dóceis. Trata-se de uma modalidade de poder produtivo, e não essencialmente restritivo, mutilador ou repressivo. Ele liga as forças para multiplicá-las e utilizá-las em sua totalidade, apropriando-se delas ainda mais e melhor. A ação do poder disciplinar é essencialmente produção de subjetividade moderna:

A disciplina "fabrica" indivíduos; ela é a técnica de um poder que toma os indivíduos ao mesmo tempo como objetos e como instrumentos de seu exercício [...]. O sucesso do poder disciplinar se deve sem dúvida ao uso de instrumentos simples: o olhar hierárquico, a sanção normalizadora e sua combinação num procedimento que lhe é específico, o exame. (Foucault, 1999b, p.143)

As técnicas da vigilância escalonada e da sanção que normaliza se unificam na produção da tecnologia do "exame", que produz efeitos de controle normalizante e uma vigilância que permite qualificar, classificar e punir. É uma tecnologia sofisticada na qual poder e saber se superpõem, se imbricam profundamente. "No coração dos processos de disciplina, ele manifesta a sujeição dos que são percebidos como objetos e a objetivação dos que se sujeitam" (ibidem, 
p.154), mecanismo no qual relações de poder permitem obter e constituir campos de saber.

A formação da sociedade disciplinar está ligada a um certo número de amplos processos históricos: transformações econômicas, jurídicas, políticas e científicas (ibidem, p.179). As disciplinas são técnicas para assegurar a ordenação das multiplicidades humanas mediante uma tática de poder específica: a) tornar o poder o menos custoso possível; b) fazer que os efeitos desse poder social sejam levados ao seu máximo de intensidade e estendidos tão longe quanto possível, sem fracasso nem lacuna; c) ligar esse crescimento "econômico" do poder e o rendimento dos aparelhos no interior dos quais se exerce (pedagógicos, militares, industriais, médicos). Elas pretendem fazer crescer ao mesmo tempo a docilidade e a utilidade de todos os elementos do sistema.

No século XVIII, temos uma conjuntura na qual a explosão demográfica foi atrelada ao crescimento acelerado do aparelho de produção, suscitando problemas que as disciplinas puderam equacionar. "As disciplinas são o conjunto de minúsculas invenções técnicas que permitiram fazer crescer a extensão útil das multiplicidades humanas, fazendo diminuir os inconvenientes do poder, que justamente para torná-las úteis, deve regê-las" (ibidem, p.181).

A decolagem econômica do Ocidente começou com processos de acumulação do capital. Já os métodos para gerir a acumulação das pessoas produziram uma decolagem política em direção a uma tecnologia minuciosa e calculada da sujeição. A disciplina caracteriza-se como um processo técnico unitário pelo qual a força do corpo é com o mínimo ônus, reduzida como força "política" e maximalizada como força útil:

$\mathrm{O}$ crescimento de uma economia capitalista fez apelo à modalidade específica do poder disciplinar [...], cujos processos de submissão das forças e dos corpos, cuja "anatomia política" [...] podem ser postos em funcionamento através de regimes políticos, de aparelhos ou de instituições muito diversas. (ibidem, p.182) 
A modalidade panóptica do poder não é um prolongamento direto nem depende imediatamente das estruturas jurídico-políticas da sociedade. A disciplina, na verdade, se constitui como um tipo especial de contradireito informal, é o substrato mesmo das liberdades formais e jurídicas. Assim como o contrato social seria o fundamento ideal do direito e do poder político, o panoptismo constitui o processo técnico-político universalmente difundido da coerção e enquadramento dos corpos e das populações. O iluminismo descobriu a liberdade e, ao mesmo tempo, inventou as disciplinas que a controlam.

Enquanto infradireito, as disciplinas: a) introduzem assimetrias insuperáveis e excluem reciprocidades, criando entre os indivíduos um laço, um vínculo informal "privado", que é uma relação de limitação inteiramente diferente da obrigação contratual. O laço disciplinar falseia o acordo contratual, exigindo muito mais da parte contratada do que prevê o acordo formal; b) diferentemente dos sistemas jurídicos que qualificam os sujeitos de direito de acordo com normas universais, as disciplinas caracterizam, classificam, especializam, distribuem ao longo de uma escala, de uma norma, hierarquizam os indivíduos em relação uns aos outros, desqualificam e finalmente, invalidam (ibidem, p.183). A contrapartida da moral burguesa seria um feixe de técnicas físico-políticas.

Por regular e institucional que seja, a disciplina, em seu mecanismo, é um contradireito. O jurisdicismo universal da sociedade moderna pretende fixar limites ao exercício dos poderes, enquanto o panoptismo difundido em toda parte faz funcionar, ao arrepio do direito, uma maquinaria ao mesmo tempo imensa e minúscula que sustenta, reforça e multiplica a assimetria dos poderes e torna vãos os limites que lhe foram traçados.

Finalmente, o poder disciplinar atingiu o limiar "tecnológico" quando a formação de saber e a majoração de poder passaram a se reforçar regularmente segundo um processo circular. Trata-se de uma arrancada epistemológica a partir de um aperfeiçoamento das relações de poder, multiplicação dos efeitos de poder graças à formação e à acumulação de novos conhecimentos (ibidem, p.184). 
O hospital, a escola, a oficina, as fábricas, os quartéis, as prisões e a polícia foram colonizados pelas disciplinas e transformados em aparelhos nos quais qualquer mecanismo de objetivação produz sujeição, onde qualquer crescimento de poder gera conhecimentos possíveis: Medicina Clínica, Psicologia da Criança, Psicopedagogia, Criminologia, racionalização do trabalho industrial. A tecnologia do exame está na base mesma da emergência das Ciências Humanas: Psicologia, Sociologia, Estatística, Pedagogia, Psiquiatria, Criminologia. Um novo tipo de poder foi capaz de produzir novos saberes. A técnica do exame disciplinar invadiu insidiosamente, e como que por baixo, uma justiça penal que é ainda, em seu princípio, inquisitória.

O ponto ideal da penalidade hoje seria a disciplina infinita: um interrogatório sem fim, que se prolongasse sem limite numa observação minuciosa e cada vez mais analítica, um julgamento que seja ao mesmo tempo a constituição de um processo nunca encerrado, o amolecimento calculado de uma pena ligada à curiosidade implacável de um exame, um procedimento que seja ao mesmo tempo a medida permanente de um desvio em relação a uma norma inacessível e o movimento assintótico que obriga a encontrá-la no infinito. (ibidem, p.187)

Veremos então, como a prisão se parece com a fábrica, com a escola, com o quartel e com o hospital e como todos eles se assemelham com a prisão.

\section{A instituição prisional como parábola da sociedade disciplinar}

Segundo Foucault (1999b, p.195ss.), a forma-prisão se constituiu fora do aparelho judiciário, quando se elaboraram, por todo o corpo social, os diversos processos para repartir os indivíduos, fixá-los, distribuí-los espacialmente e classificá-los, visando tirar deles 
o máximo de tempo e de forças, treinando seus corpos, codificando seu comportamento continuamente, mantendo-os sob uma visibilidade sem lacunas, formando em torno deles um aparelho completo de observação, registro e anotações, produzindo sobre eles um saber que se acumula e se centraliza. A forma geral de uma aparelhagem para tornar os indivíduos dóceis e úteis, mediante um trabalho preciso sobre seu corpo, criou a instituição prisão antes que a lei a definisse como pena por excelência.

Na passagem do século XVIII para o XIX, criou-se a penalidade da detenção. Nesse momento, os mecanismos disciplinares colonizaram a instituição judiciária. A legislação definiu o poder de punir como função geral da sociedade, exercido da mesma maneira sobre todos os seus membros, e na qual cada um deles é igualmente representado. A justiça que se dizia "igual" para todos, organizada num aparelho judiciário "autônomo", foi investida pelas assimetrias das sujeições disciplinares e passou a fazer da detenção a pena civilizada por excelência. Rapidamente esse processo foi "naturalizado" e a prisão-castigo assumiu logo um caráter de obviedade social.

Apesar de todos os inconvenientes, do seu perigo e inutilidade, não se tem ideia do que poderia substituir a detestável invenção prisional. Ela é aceita com naturalidade por se fundamentar na forma simples da "privação da liberdade". Numa sociedade de homens livres, na qual a liberdade é um bem de todos, privar o indivíduo dela é aceitável como uma pena "igualitária”. Isso oferece uma clareza jurídica para a prisão que não agride a sensibilidade do homem moderno. Ela também permite quantificar a pena segundo a variável do tempo. Usa-se o tempo para medir as trocas econômicas, calculando o salário por horas trabalhadas e é possível aplicar esse cálculo no castigo penal. Além disso, a prisão aparece ainda como reparação: retirar tempo do condenado significa que sua infração lesou, além da vítima, toda a sociedade.

Obviedade econômico-moral de uma penalidade que contabiliza os castigos em dias, meses, anos, estabelecendo equivalências quantitativas de delitos-duração. Contrariando a teoria do direito, diz-se que a pessoa está na prisão para "pagar sua dívida" (Foucault, 
1999b, p.196). A prisão é óbvia também em sua tarefa, suposta ou exigida, de transformar os indivíduos. Ao encarcerar, ao retreinar, ao reeducar e tornar dócil, a prisão apenas reproduz, de modo acentuado, todos os mecanismos encontrados no corpo social: ela seria apenas um quartel estrito, uma escola sem indulgência, uma oficina sombria e meticulosamente organizada.

São dois os fundamentos que fizeram a prisão parecer a forma mais imediata e civilizada das penas: a dimensão jurídico-econômica (articulando as variáveis da liberdade e do tempo) e a dimensão técnico-disciplinar (articulando a privação da liberdade e a técnica corretiva). A prisão foi desde o princípio uma "detenção legal" encarregada de um suplemento corretivo: instituição de modificação dos indivíduos que a privação da liberdade permite fazer funcionar no sistema legal, visando sua ressocialização. $\mathrm{O}$ encarceramento penal, desde o início do século XVIII, recobriu ao mesmo tempo a privação de liberdade e a transformação técnica dos indivíduos.

$\mathrm{O}$ encarceramento deve ser um mecanismo diferenciado e ter finalidades específicas: o castigo é graduado em intensidade e diversificado em seus objetivos. Um condenado vai para a cadeia, o contraventor para a casa de correção ou reformatório, o criminoso para a penitenciária. A prisão é a pena prescrita que repara o crime e recupera o culpado. A transformação do detento é produzida pela organização das relações de poder no plano intrainstitucional do aparelho prisional. As técnicas corretivas são parte integrante e estrutural do estabelecimento prisional.

A constante "reforma" da instituição prisão é mais ou menos contemporânea do seu surgimento: necessidade de criar mecanismos de acompanhamento, que aparentemente devem corrigi-la, mas que fazem parte do seu próprio funcionamento (prisão semper reformanda). A "teoria da prisão" (Foucault, 1999b, p.198) sempre foi uma das condições de possibilidade de sua própria existência. A prisão sempre fez parte de um campo ativo, onde são numerosos os projetos, os remanejamentos, as experiências, os discursos teóricos, os testemunhos, os inquéritos. Área conflitiva permanentemente constituída pelas tecnologias corretivas do indivíduo. 


\section{Operadores técnicos para a reeducação prisional e a criação do "delinquente"}

A prisão, aparelho disciplinar exaustivo, toma a seu cargo todos os aspectos da vida do indivíduo, cuidando dele com zelo totalitário: treinamento físico, aptidão para o trabalho, comportamento cotidiano, atitude moral e disposições. Ela é "onidisciplinar": disciplina incessante, sem exterior nem lacuna, não se interrompe, a não ser depois de terminada totalmente sua tarefa, sua ação sobre o indivíduo é ininterrupta. Também possui uma disciplina despótica, dando poder quase total sobre os detentos e com mecanismos internos de repressão e de castigo. A solitária é a prisão da prisão. Ela tem que ser a maquinaria mais potente para impor uma nova forma ao indivíduo pervertido e seu modo de ação é a coação de uma educação integral, total (Foucault, 1999b, p.199).

A prisão utiliza diversos operadores, instrumentos técnicos para promover a reeducação do indivíduo detido (ibidem, p.199-208), como seguem:

a) O "isolamento individual" separa o detento do ambiente social que estimulava a criminalidade e dos demais prisioneiros também. A solidão é empregada como um instrumento positivo de reforma moral, permitindo a autorregulação da pena e uma individualização espontânea do castigo. $\mathrm{O}$ isolamento propicia uma influência completa e única sobre o prisioneiro, condição fundamental para a submissão total;

b) O "trabalho" é parte integrante do regime de detenção, elemento de punição. O trabalho penal educativo inclui intrinsecamente um princípio de ordem e regularidade, vinculando de maneira insensível as formas de um poder rigoroso e modelador do comportamento;

c) O "excesso penitenciário", pelo qual a prisão toma para si a função de modular a pena do detento: a duração do castigo fica sob a responsabilidade e administração penitenciária. A justa duração da pena varia, portanto, conforme seu próprio 
desenrolar concreto. Todo um campo do arbitrário se constitui progressivamente do lado do poder que gere e controla a punição. É a equipe dirigente que constata, diagnostica, caracteriza com precisão, classifica diferencialmente e passa a modular internamente a pena prescrita.

A prisão, portanto, declara a independência carcerária em relação à detenção legal do judiciário, reivindicando o direito de ser um poder que tem não somente autonomia administrativa, mas como que uma parte da própria soberania punitiva. Esse excesso do encarceramento não é uma disfunção do sistema prisional, e sim, parte integrante da prisão e a acompanha desde seu surgimento. A grande maquinaria carcerária está ligada ao próprio modo de funcionamento da prisão.

A prisão deve ser uma instituição útil, suas tarefas consistem em privar de liberdade e realizar transformações nos indivíduos. Para dar conta delas, o aparelho carcerário recorreu a três grandes estratégias: o esquema político-moral do isolamento individual e da hierarquia (modelo da cela); o esquema econômico da força aplicada a um trabalho obrigatório (modelo da oficina); o esquema técnico-médico da cura e da normalização (modelo do hospital).

Assim, a prisão excede a detenção jurídica por meio de técnicas de tipo disciplinar e desse suplemento disciplinar que se denomina o "penitenciário". O suplemento penitenciário conseguiu se impor porque introduziu a justiça criminal em relações de saber "cientificas”. A prisão, local de execução da pena, é, ao mesmo tempo, local de observação dos indivíduos punidos: vigilância para controlar os detentos, mas também conhecimento de cada prisioneiro, de seu comportamento, de suas disposições profundas e de sua progressiva melhora. Ali se produz um conhecimento, um saber clínico sobre os condenados.

Para que isso se efetive, são necessários dois operadores: a) o panoptismo, que permite ao olho do poder disciplinar vigiar e observar com segurança e saber, produzindo individualização e totalização, isolamento e transparência. Nesse sentido, a problematização técni- 
ca e terapêutica da arquitetura torna transparente a gestão do poder; b) o sistema de registros e de documentação que, por meio de relatórios individualizantes e permanentes, permite criar um sistema de "conta moral", boletim individual de modelo uniforme no qual a equipe dirigente e seus auxiliares devem escrever suas observações sobre cada detento (Foucault, 1999b, p.209-10).

Trata-se de fazer da prisão um local de constituição de um saber que deve servir de princípio regulador para o exercício da prática penitenciária. A coleta de dados permanente permite que a prisão transforme a medida penal judiciária em uma operação carcerária, ao criar um novo objeto institucional específico: o "delinquente". O aparelho penitenciário, com todo seu programa tecnológico, efetua uma importante substituição: a justiça encaminha para a prisão um condenado (objeto jurídico), mas a prisão o recebe como um delinquente (objeto e personagem criado pela Criminologia) (ibidem, p.211).

O delinquente recolhido na prisão passa a ser um indivíduo que deve ser conhecido. Se o infrator é caracterizado juridicamente por seu ato, o delinquente é caracterizado por uma vida singular. Desse modo, o castigo legal se refere a um ato, mas a técnica punitiva abrange uma vida toda, num processo de reeducação totalizante da existência do delinquente. Para isso, é muito importante o conhecimento da biografia do detento, pois ela pode revelar a lenta formação do seu caráter degenerado. Nesse ponto, a trama dos discursos psicológicos, psiquiátricos e penais produz o "criminoso" antes do crime e até mesmo fora dele. Temos a invenção da noção de "indivíduo perigoso" pela Criminologia, que permite estabelecer uma rede de causalidade na escala de uma biografia inteira e determinar com clareza e segurança o veredicto de punição e correção.

A técnica penitenciária e o delinquente são realidades que se produzem concomitantemente e no prolongamento uma da outra, como um conjunto tecnológico que forma e recorta o objeto a que aplica seus instrumentos. A delinquência não é um objeto natural, não possui consistência ontológica nem foi supostamente descoberta finalmente por uma racionalidade científica. Objeto da Cri- 
minologia, o "delinquente" permite constituir, com a garantia da Medicina e da Psicologia, um indivíduo no qual o infrator da lei e o objeto de uma técnica científica se superpõem de modo aproximado (Foucault, 1999b, p.214). Temos aí a produção de sujeitos no bojo mesmo de relações entre saberes e poderes num contexto institucional específico.

O enxerto da prisão no sistema penal permitiu a fabricação da delinquência, dando à justiça criminal um campo unitário e específico de objetos, autenticados por "ciências" que lhe permitiram funcionar num horizonte geral de "verdade". Desse modo, a prisão é o local onde o poder de punir organiza silenciosamente um campo de objetividade em que o castigo poderá funcionar em plena luz como terapêutica e a sentença se inscreverá entre os discursos do saber.

\section{O fracasso da prisão e sua função de gerenciamento das ilegalidades}

A detenção legal tomou o lugar do suplício do corpo na forma de um dispositivo cuidadosamente articulado, cuja função técnica estava desenhada para modificar os indivíduos. Mas a denúncia do fracasso da justiça penal foi imediata, tanto em relação à sua realidade institucional quanto aos seus efeitos mais visíveis (Foucault, 1999b, p.221-4). Do mesmo modo que o projeto de uma técnica corretiva acompanhou o princípio de uma detenção punitiva, a crítica da prisão e de seus métodos também apareceu com ela.

Essa crítica ainda é bastante pertinente em suas formulações: a) a prisão não diminui a taxa de criminalidade, pode até mesmo aumentá-la, multiplicá-la ou transformá-la; b) a detenção provoca a reincidência; c) ela não pode deixar de fabricar delinquentes, pois os abusos de poder de uma administração arbitrária impõem aos detentos limitações violentas, contrariando os objetivos oficiais de aplicar as leis e ensinar a respeitá-las; d) a prisão funciona como um quartel do crime onde se (des)educa os jovens delinquentes; e) a 
liberdade condicional vigiada e tutelada promove a reincidência; f) a família do detento fica exposta à miséria e ao desamparo, condições propícias para a criação de novos delinquentes.

Segundo as críticas, a prisão não é efetivamente corretora, a técnica penitenciária permanece em estado rudimentar, e quando ela quer ser corretiva, perde sua força punitiva, pois a verdadeira técnica penitenciária seria o rigor. Duplo erro econômico se verifica nesse estabelecimento prisional: sua organização custa muito caro e é um desperdício, pois ele não reprime nem reeduca.

A reação da prisão às críticas consiste em recrudescer os princípios da técnica penitenciária, visando reparar seu fracasso permanente e intensificando a realização do seu projeto corretivo como único método para superar a impossibilidade de torná-lo realidade. São sete os princípios da teoria penitenciária, permanentemente reativados e igualmente destinados ao fracasso (Foucault, 1999b, p.224-5):

a) "princípio da correção": a detenção penal deve ter por função essencial a transformação do comportamento do indivíduo, visando sua recuperação e reeducação, ressocializando o condenado;

b) "princípio da classificação": os detentos devem ser isolados ou repartidos de acordo com a gravidade penal do seu ato, mas principalmente segundo sua idade, disposições, as técnicas de correção que se pretende aplicar neles e as fases de sua transformação;

c) "princípio da modulação das penas": elas poderão ser moduladas de acordo com seu desenrolar no ambiente institucional, a individualidade dos detentos, a partir dos resultados obtidos e os progressos ou as recaídas constatadas. Trata-se de uma personalização da técnica penitenciária;

d) "princípio do trabalho penal como obrigação e direito": peça fundamental no processo de transformação e socialização progressiva dos detentos, com função essencialmente disciplinar; 
e) "princípio da educação penitenciária": a educação do detento, sua instrução geral e profissional são consideradas fundamentais para sua melhora;

f) "princípio do controle técnico da detenção": o regime institucional da prisão deve ser, pelo menos em parte, controlado e assumido por um pessoal especializado que possua as capacidades morais e técnicas de zelar pela boa formação dos indivíduos, tais como médicos, assistentes sociais, psicólogos, psiquiatras, professores, pedagogos, padres etc.;

g) "princípio das instituições anexas": o encarceramento deve ser acompanhado por medidas de controle e de assistência até a readaptação definitiva do antigo detento, visando vigiá-lo até sua saída da prisão, prestar-lhe apoio e ajuda, buscando sua reinserção social adequada.

O sistema carcerário é um conjunto complexo, combinando numa mesma figura discursos, arquitetura, regulamentos coercitivos e proposições científicas, efeitos sociais reais e utopias invencíveis, programas para corrigir a delinquência e mecanismos que a solidificam, contraditoriamente. $\mathrm{O}$ fracasso e a reforma permanente da prisão são partes integrantes do seu funcionamento. É desse modo que ela pode desempenhar papéis e funções muito específicas no conjunto social.

Para que serve o fracasso da prisão? Qual é a utilidade desses fenômenos que a crítica continuamente denuncia: manutenção da delinquência, indução em reincidência, transformação do infrator ocasional em delinquente? Foucault afirma que a prisão e seus castigos não se destinam a suprimir as infrações, mas antes, a distingui-las, a distribuí-las, a utilizá-las. Visam não tanto tornar dóceis os que estão prontos a transgredir as leis, mas tendem a organizar a transgressão das leis numa tática geral das sujeições (Foucault, 1999b, p.226).

A penalidade seria então uma maneira de gerir as ilegalidades, riscar limites de tolerância, dar espaços a alguns, fazer pressão sobre outros, excluir uma parte, tornar útil outra, neutralizar estas, poten- 
cializar e tirar proveito daquelas. Não se trata de "reprimir" as ilegalidades, mas de diferenciá-las, promovendo sua economia geral: produção, análise e utilização das ilegalidades.

Assim como podemos falar de uma estratégia global que implementa táticas de sujeições, de mecanismos gerais de dominação, existe uma gestão diferencial das ilegalidades que funciona por meio da penalidade, instrumento penal da justiça. Os castigos legais devem ser localizados numa estratégia global de gestão das ilegalidades. O enigma do fracasso da prisão torna-se compreensível com essa hipótese.

A construção da sociedade nos séculos XVIII e XIX procurou gerenciar as diversas ilegalidades populares, enquanto formulava a utopia de uma sociedade universal e publicamente punitiva, na qual mecanismos penais onipresentes implementariam uma lei duplamente ideal: perfeita em seus cálculos e presente na representação de cada cidadão, bloqueando, desde a origem, qualquer prática de ilegalidade (Foucault, 1999b, p.229). A prisão, ao "fracassar", aparentemente,

[...] não erra seu objetivo; ao contrário, ela o atinge na medida em que suscita no meio de outras, uma forma particular de ilegalidade, que ela permite separar, por em plena luz e organizar como um meio relativamente fechado mas penetrável. Ela contribui para estabelecer uma ilegalidade, visível, marcada, irredutível a um certo nível e secretamente útil, rebelde e dócil ao mesmo tempo; desenha, isola e sublinha uma forma de ilegalidade que parece resumir simbolicamente todas as outras, mas que permite deixar na sombra as que ser quer ou que se deve tolerar. Essa forma é a delinquência propriamente dita. (ibidem, p.230)

A delinquência é uma das formas da ilegalidade que, apesar de ter suas raízes na prisão, é uma ilegalidade fabricada pelo "sistema carcerário" que a investiu, recortou, penetrou, organizou, fechou num meio definido e ao qual deu um papel instrumental, em relação às outras ilegalidades. Assim como há uma oposição jurídica entre a 
legalidade e a prática ilegal, há uma oposição estratégica entre ilegalidades e a delinquência no campo social.

$\mathrm{O}$ atestado de que a prisão fracassa em reduzir os crimes talvez deva ser substituído pela hipótese de que a prisão conseguiu muito bem produzir a delinquência, tipo especificado, forma política e economicamente menos perigosa - talvez até utilizável - de ilegalidade, produziu o delinquente como sujeito patologizado (Foucault, 1999b, p.231-3).

A prisão é a instituição que articula dois mecanismos, permitindo que ambos se reforcem mutuamente: promove a "objetivação científica” da delinquência por detrás da infração e, numa "operação política", consolida a delinquência no movimento caótico das ilegalidades. É por isso que se justifica que a prisão continue a existir, produzindo os mesmos efeitos e causando os maiores escrúpulos em derrubá-la: a ilegalidade e a legalidade burguesa colonizaram a delinquência.

\section{Arranjo atual dos mecanismos punitivos na sociedade moderna}

A organização de uma ilegalidade isolada e especificada na delinquência exige, como sua condição de possibilidade, o desenvolvimento de controles policiais, em sua função de fiscalização geral, controle e vigilância da população.

Essa vigilância só pode funcionar conjugada com a prisão: prisão e polícia formam um dispositivo geminado. Juntas, realizam em todo o campo das ilegalidades, a diferenciação, o isolamento e a utilização da delinquência. Nas ilegalidades, o sistema polícia-prisão corresponde a uma delinquência manejável, efeito, engrenagem e instrumento daquele. Trata-se de um conjunto de três termos: polícia-prisão-delinquência, que se apoiam uns sobre os outros e formam um circuito que nunca é interrompido (Foucault, 1999b, p.234).

Desse modo, a justiça penal é apenas um instrumento para o controle diferencial das ilegalidades. A justiça criminal é um nó 
institucional numa economia geral das ilegalidades, cujas peças fundamentais são a polícia, a prisão e a delinquência. Esse processo é efetivo, mas seus resultados nunca são definitivos. São táticas que se deslocam na medida em que nunca atingem inteiramente seus objetivos. Sempre encontram resistências, lutas e reações.

Tais táticas tiveram efetivamente vitórias e conquistas em seus múltiplos procedimentos, mas não triunfaram plenamente, nem conseguiram produzir uma ruptura total entre os delinquentes e as camadas populares. Como resposta às afirmações filantrópicas que associam pobreza-dissipação-preguiça-bebedeira-vício-roubo-crime, uma análise política da criminalidade encontra o ponto de origem da delinquência não no indivíduo criminoso e sim na sociedade (ibidem, p.238) que seria uma "desordem institucionalizada", um verdadeiro campo de batalha.

A delinquência das classes dominantes costuma ser a causa da delinquência popular e sempre é sua amplificação. A delinquência dos ricos seria tolerada pelas leis e quando vai ao tribunal, está sempre segura de sua indulgência. Por isso, processos criminais se tornam ocasião de debate político para denunciar o funcionamento geral da justiça penal. Daí também que os prisioneiros políticos, que estão em condição de se fazer ouvir, têm o dever de ser porta-vozes de todos os detentos, uma vez que também vivenciaram uma experiência direta do sistema penal. Há ainda o "contranoticiário policial": jornais populares que destacam a delinquência da burguesia, narram as misérias dos exploradores do povo, revelam a responsabilidade da sociedade e de empresários nos processos criminais contra trabalhadores.

Para Foucault (1999b, p.240), não há então natureza criminosa, mas jogos de força que, segundo a classe a que pertencem os indivíduos, os conduzirão ao poder, se forem ricos, ou à prisão, se forem pobres. Nesse caso, a existência do crime, mais do que uma fraqueza ou uma patologia, manifesta e expressa uma energia que se levanta, "um brilhante protesto da individualidade humana".

Há uma batalha acontecendo no campo social, onde múltiplas forças buscam impor sua hegemonia. Quando se faz aparecer o jogo de 
forças que se opõem reciprocamente, podemos analisar o crime como a volta fatal e a revolta do que é reprimido: as pequenas ilegalidades não são margens necessárias da sociedade, mas são embates guerreiros que aí se desenrolam. Onde há poder, hegemonia e dominação, encontraremos também contrapoder, resistência e sublevação.

Os homens resistem às táticas disciplinares do poder porque possuem e utilizam sua liberdade nata e imediata. A indisciplina e a ilegalidade se erguem como direito e possibilidade do exercício mesmo da liberdade. Nesse sentido, a proposta de Foucault (1999b, p.242) é que devemos buscar desligar a delinquência de sua relação com a legalidade e ilegalidade burguesa que a colonizaram.

\section{Um reformatório como caso singular e o arquipélago carcerário}

A colônia de Mettray (Foucault, 1999b, p.243) é um reformatório francês construído a partir de uma nova política punitiva do corpo. Sua forma disciplinar é intensa e seu modelo concentra todas as tecnologias coercitivas do comportamento: ela tem aspectos do claustro monástico, da prisão, do colégio e do regimento militar. Os rapazes ali confinados são divididos em pequenos grupos fortemente hierarquizados, de acordo com cinco modelos de referência: a) esquema da família (grupo composto por "irmãos" e "pais"); b) esquema do exército (grupo comandado por um chefe, dividido em seções com subchefes, número de matrícula, aprendizado de exercícios militares básicos, revistas de limpeza do corpo e das roupas e chamadas realizadas três vezes ao dia); c) esquema da oficina (chefes e contramestres asseguram o aprendizado do trabalho); d) esquema escolar (professor e monitores ministram aulas); e) esquema judiciário (o microtribunal penal realiza todos os dias uma "distribuição de justiça”, cuja penalidade principal é a solitária na qual se lê nas paredes em letras pretas: "Deus o vê").

Essa superposição de modelos diferentes permite determinar a função de "adestramento" no que ela tem de específico: a equipe 
dirigente tem a função de "técnicos do comportamento, engenheiros da conduta, ortopedistas da individualidade" (Foucault, 1999b, p.244). Ela fabrica, ao mesmo tempo, corpos dóceis e capazes de trabalhar, utilizando uma observação permanente que avalia continuamente o comportamento cotidiano dos detentos. Trata-se de um saber organizado como instrumento de apreciação perpétua.

A modelagem do corpo dá lugar a um conhecimento do indivíduo, o aprendizado das técnicas induz a modos de comportamento e a aquisição de aptidões se mistura com a fixação de relações de poder; formam-se bons agricultores, vigorosos e hábeis. Nesse mesmo trabalho, desde que tecnicamente controlado, são fabricados indivíduos submissos e constitui-se sobre eles um saber em que se pode confiar. Duplo efeito dessa técnica disciplinar que é exercida sobre os corpos: uma "alma" a conhecer e uma sujeição a manter.

Nessa operação de adestramento, Mettray é exemplar e específica. Ela se aproxima de outras formas de controle sobre as quais se apoia: medicina, educação escolar, direção espiritual religiosa. Mas não se confunde com elas, nem com a administração propriamente dita. A equipe dirigente vivia permanentemente com os rapazes reclusos, constituindo no meio deles uma rede de observação perpétua. Tal equipe era formada numa escola especializada, onde se submetia aos mesmos aprendizados e coerções que seriam utilizados mais tarde com os detentos. Os membros da equipe dirigente eram submetidos à mesma disciplina que deveriam, como educadores, impor aos jovens. Aprendiam na prática, a técnica, "a arte das relações de poder" (Foucault, 1999b, p.245), mais do que teorias. O "penitenciário", a "lógica totalitária" é uma técnica que se aprende, se transmite, e que obedece às normas gerais. A técnica disciplinar tornou-se um saber e fez escola. É a partir desse limiar diferencial que surge, nessa época, a Psicologia Científica, com profissionais da disciplina, da normalidade e da sujeição.

Mettray está no limite da penalidade estrita. Outras instituições, bem além do direito penal, construíram o "arquipélago carcerário" (Foucault, 1999b, p.246): colônias agrícolas para adultos e crianças pobres, abandonadas e vadias, refúgios para tirar moças e meninas 
da prostituição, colônias penitenciárias industriais, orfanatos para crianças abandonadas ou indigentes, estabelecimentos para aprendizes, fábricas-conventos etc. Houve um alargamento dos círculos carcerários e nessas instituições a prisão foi se diluindo lentamente, até desaparecer por completo.

Houve também uma série de dispositivos que não reproduz a prisão "compacta”, mas utiliza alguns dos mecanismos e técnicas carcerárias: patronatos, obras de moralização, centrais de distribuição de auxílios e vigilância e a construção de cidades operárias.

Há uma grande organização carcerária que reúne todos os dispositivos disciplinares que funcionam disseminados na sociedade. As fronteiras entre o encarceramento, os castigos judiciários e as instituições de disciplina tendem a desaparecer para constituir um grande continuum carcerário que difunde as técnicas penitenciárias até as disciplinas mais inocentes; transmite as normas disciplinares até a essência do sistema penal e faz pesar sobre a menor ilegalidade, sobre a mínima irregularidade, desvio ou anomalia, a ameaça da delinquência.

"Uma rede carcerária sutil, graduada, com instituições compactas, mas também com procedimentos parcelados e difusos, encarregou-se do que cabia ao encarceramento arbitrário" (Foucault, 1999b, p.246). Assim como a justiça penal, por meio da prisão, transforma o processo punitivo em técnica penitenciária, o arquipélago carcerário transporta essa técnica da instituição penal para o corpo social inteiro, num investimento capilar e microfísico.

Foucault (1999b, p.247-53) apresenta alguns efeitos importantes desse processo de difusão capilar do poder disciplinar no campo social:

a) A rede carcerária acopla, segundo múltiplas relações, as duas séries longas e múltiplas do punitivo e do anormal. Há uma gradação lenta, contínua, imperceptível, que permite passar como que naturalmente do plano da lei $\rightarrow$ infração para o plano da norma $\rightarrow$ desvio. O encarceramento, com seus mecanismos de vigilância e punição, funciona segundo um 
princípio de relativa continuidade dos critérios e mecanismos punitivos que a partir do simples desvio fazem pesar cada vez mais a regra e agravam a sanção. Há uma gradação das instituições e das autoridades instituídas, especializadas e competentes (na ordem do saber e do poder) que, sem arbitrariedade, mas segundo regulamentos mediante verificações e medidas, hierarquizam, diferenciam, sancionam, punem e vão, pouco a pouco, da sanção dos desvios ao castigo dos crimes;

b) O carcerário, com seus canais, organiza o adestramento para a docilidade, ao mesmo tempo que fabrica os delinquentes, pelos mesmos mecanismos. Não existe, nesse caso, exclusão social, pois o delinquente não está fora da lei. Ele está, desde o início, bem no centro dos mecanismos que fazem passar insensivelmente da disciplina para a lei, do desvio à infração. O delinquente é produto da instituição e a criminalidade é produzida mediante uma acumulação de coerções disciplinares, graças a inserções cada vez mais rigorosas e de vigilâncias cada vez mais insistentes;

c) A difusão do sistema carcerário no tecido social naturaliza e legitima o poder de punir e baixa o limite de tolerância à penalidade. Tende a apagar o que possa haver de exorbitante no exercício do castigo, fazendo funcionar um em relação ao outro, os dois registros nos quais esse poder punitivo se divide: registro da justiça, plano da lei e da legalidade, e registro da disciplina, plano da norma e do extralegal. "Em sua função, esse poder de punir não é essencialmente diferente do de curar ou educar" (Foucault, 1999b, p.250). O carcerário "naturaliza" o poder legal de punir e "legaliza" o poder técnico de disciplinar;

d) A onipresença dos dispositivos disciplinares, apoiando-se nos dispositivos carcerários se transformou em poder normalizador. Temos em nossa sociedade, juízes da normalidade em toda parte: professores, médicos, educadores, assistentes sociais, psicólogos, psicanalistas, psiquiatras. Todos fazem 
reinar a universalidade do normativo e, cada um no lugar social em que se encontra, aí submete os corpos, os gestos, os comportamentos, as condutas, as aptidões e os desempenhos;

e) Finalmente, a constituição disciplinar da sociedade implica uma nova economia do poder, utilizando um dispositivo de punição e um instrumento para a formação de um saber. $\mathrm{O}$ nascimento das Ciências Humanas é contemporâneo de uma modalidade nova de poder: uma política do corpo específica que torna dócil e útil a acumulação dos homens. Essa exigia a implicação de correlações definidas de saber nas relações de poder: reclamava uma técnica para entrecruzar a sujeição e a objetivação, incluindo novos procedimentos de individualização. O funcionamento panóptico do poder disciplinar permitiu o desenvolvimento de uma imensa atividade de exame que objetivou o comportamento humano. A multiplicidade e o entrecruzamento preciso dos diversos mecanismos de encarceramento possibilitaram que a tecnologia do exame se estendesse amplamente pela sociedade, constituindo as Ciências Humanas. O homem conhecível (alma, individualidade, consciência, comportamento) é o efeito-objeto desse investimento analítico, dessa dominação-observação;

f) Essas hipóteses explicariam a solidez da prisão e a grande força de inércia que opõe a quem quisesse modificá-la: está encaixada no meio de dispositivos e de estratégias de poder. O funcionamento panóptico e extrajudiciário da sociedade dificulta a modificação do regime de encarceramento. A prisão é fundamental como instrumento de recuperação na rede de vigilâncias e disciplinas, mas isso não significa que a prisão não possa ser modificada ou suprimida. A delinquência fabricada pela prisão é demasiado grosseira para explorar as grandes ilegalidades ligadas aos aparelhos políticos, econômicos e sociais (Salla, 2000). Por outro lado, os profissionais das Ciências Humanas assumem cada vez mais poderes e funções judiciárias de sanção e de controle. Esses fenômenos podem levar ao desaparecimento da forma prisão. 
A prisão constituía, pela defasagem entre seu discurso penitenciário e seu efeito de consolidação da delinquência, uma engrenagem que articulava o poder penal e o poder disciplinar. Quanto mais o aparelho penal se medicalizar, psicologizar, sociologizar e pedagogizar, menos útil será a prisão em meio a todos esses dispositivos de normalização. A alternativa estaria na prisão ou em algo diferente dela. Foucault (1999b, p.253) conclui que o problema estaria mais no grande avanço desses dispositivos de normalização e em toda extensão dos efeitos de poder que eles trazem, por meio da colocação de novas objetividades e da criação de novos objetos sobre os quais se debruçam. 


\section{4 \\ GOFFMAN E FOUCAULT: SEMELHANÇAS E DIFERENÇAS}

Certamente podemos encontrar muitos pontos de contato entre algumas perspectivas de Foucault relativas à sociedade disciplinar e suas instituições e os estudos de Goffman sobre as instituições totais (Benelli; Costa-Rosa, 2003a, Ferreira, 2012). Isso pode ser constatado na apresentação dos casos singulares estudados a seguir. Mas também é importante ressaltar que há diferenças importantes entre ambos, como se pode verificar em Foucault (1995, p.231-49): ele estuda particularmente os modos como os seres humanos são constituídos como sujeitos sociais em meio a complexas e múltiplas relações de saberes e poderes.

Foucault (1999b, p.120), ao estudar a disciplina, indica que uma nova "microfísica do poder" constituída por "técnicas sempre minuciosas muitas vezes íntimas, importantes porque definem um certo modo de investimento político e detalhado do corpo", emergiu no mundo moderno e espalhou-se por todo o corpo social. "A disciplina é uma anatomia política do detalhe: trata-se de 'pequenas astúcias' dotadas de um grande poder de difusão, arranjos sutis e aparência inocente, mas profundamente suspeitas, dispositivos que obedecem a economias inconfessáveis, ou que procuram coerções sem grandeza" (ibidem). Para descrever os mecanismos disciplina- 
res, é preciso demorar-se sobre os detalhes e na atenção às minúcias, buscando detectar sua coerência tática.

Acreditamos que Goffman (1987) tenha como programa justamente proceder a uma observação minuciosa do detalhe, buscando ao mesmo tempo um enfoque político dessas pequenas coisas do cotidiano, utilizadas para o controle, dominação e - diremos também - produção de subjetividade no contexto institucional.

Goffman (1987, p.145-259), em seu artigo "A vida íntima de uma instituição pública”, por exemplo, realiza uma perspicaz análise das práticas sociais que se produzem no contexto institucional de um hospital psiquiátrico, denominado "Hospital Central". Ao deter-se nos detalhes da organização intrainstitucional do dispositivo manicomial, ele mapeia e cartografa com meticulosidade toda uma "geografia" do poder, detectando com precisão seus diversos deslocamentos: estratégias de dominação, de produção de subjetividade, focos de resistência, táticas de subversão do instituído e movimentos instituintes.

Para além de uma linguagem de certo modo ainda funcionalista, utilizada por Goffman (1987, p.148), por exemplo, em expressões tais como: "a participação numa entidade social impõe compromisso e adesão", dando a entender, inicialmente, que indivíduo, instituição e estabelecimento seriam coisas distintas, podemos perceber em suas análises, se lidas com atenção, como sujeitos e instituições se produzem mutuamente, numa completa implicação. As práticas institucionais produzem sujeitos como efeito dessas práticas, que por sua vez são tomados como alvos de manutenção delas ou se organizam como focos de resistência à ordem institucional. Podemos aprender com Goffman como o poder, ao enformar práticas sociais que visam o corpo do homem, transforma-o num indivíduo e também num objeto científico, ao aprisioná-lo em uma certa "natureza" ou "identidade", fruto das relações poder/saber, caracterizando-o como louco, delinquente etc.

A vida no contexto institucional produz "suposições" referentes à natureza, aos modos de ser e agir dos seus diversos habitantes: costuma ser normativa e normativizante. Esses atores institucionais 
podem enfrentar de modo variável essa "definição de si mesmos" que o estabelecimento produz: podem resistir abertamente "e desafiar com desfaçatez os olhares de redefinição que as pessoas lhes dirigem" (Goffman, 1987, p.149); podem recusar veladamente esse assujeitamento e, finalmente, reconhecer-se nessa definição institucional do seu ser, "sendo, diante de si mesmos, aquilo que os outros participantes acham que devem ser" (ibidem). Podemos destacar aqui a relevância da sutileza efetiva do poder enquanto olhar e visibilidade, que será objeto de discussão em Foucault (1984, 1999b).

Goffman (1987) estudou detalhadamente a estrutura, a natureza e a dinâmica psicossocial das "instituições totais" e sua análise mostra-se um instrumento valioso para estudar a produção da subjetividade no contexto institucional (Benelli, 2006, 2007). Quando situamos as sofisticadas e minuciosas análises de Goffman num campo mais geral da evolução da análise das instituições, campo de referências históricas que encontramos, por exemplo, na obra de Michel Foucault (1999a, 1999b), então elas ganham um sentido mais pleno e o que parecia apenas implícito pode se articular claramente.

Foucault é conhecido por não citar suas fontes e, até mesmo, chegou a comentar a importância do estudo das instituições asilares realizado por Goffman (Foucault, 1984, p.110-11). Pensamos que há mais semelhanças entre Manicômios, prisões e conventos (publicado originalmente em 1961) e Vigiar e punir (publicado originalmente em 1975) do que se poderia suspeitar à primeira vista. Isso não parece evidente, mas uma leitura atenta de ambos pode indicar pontos de contato, temas, problemas e achados comuns nos dois autores, como tentamos demonstrar. Com isso não negamos suas diferenças e distâncias, nem as especificidades de cada obra em si mesma. Mas as ressonâncias de um livro no outro nos pareceram bastante notáveis.

Talvez pudéssemos afirmar que há mais vida no Panopticon do que Bentham (Foucault, 1984, 1999b) poderia - ou gostaria - de acreditar. O projeto de controle e visibilidade total de Ben- 
tham falha, pois focos de resistência tendem a se apoderar de todo e qualquer espaço vulnerável do dispositivo institucional "Esses são os recantos úmidos onde nascem os ajustamentos secundários e de onde começam a infestar o estabelecimento" (Goffman, 1987, p.247).

Uma leitura foucaultiana de Goffman (1987) revela um "genealogista”, pois nos permite verificar como as relações de poder/saber produzem práticas não discursivas, discursivas e subjetividade na instituição total. Com Goffman aprendemos que o manicômio possui estrutura física e simbólica, onde poderes e saberes se produzem, gerando modelos profissionais e um clima cultural específico. Desmontá-lo implica a invenção de novas instituições, partindo da ruptura epistemológica produzida pela instituição negada: a desinstitucionalização exige a elaboração de um novo paradigma (Nicácio, 1994; Costa-Rosa, 2000).

Novas instituições exigem, para sua criação, um exercício cotidiano de elaboração contínua de um projeto a partir da reflexão permanente sobre as práticas, num esforço de transformar a lógica e ação asilares. Nesse trabalho, Goffman (1987) tem uma grande contribuição a nos oferecer.

A "experiência italiana" na área da Saúde Coletiva propõe a superação do tratamento baseado na internação psiquiátrica. Sua proposta é um projeto de desmonte peça a peça, da máquina kafkiana que Goffman (1987) nos revelou. Rotelli, apontando para a questão central, afirma que o objetivo prioritário da desinstitucionalização é transformar as relações de poder entre instituição e sujeitos e, em primeiro lugar, os pacientes.

Inicialmente, isto é, no trabalho de desconstrução do manicômio, esta transformação é produzida através de gestos elementares: eliminar os meios de contenção; reestabelecer a relação do indivíduo com o próprio corpo; reconstruir o direito e a capacidade de uso dos objetos pessoais; reconstruir o direito e a capacidade de palavra; eliminar a ergoterapia; abrir as portas; produzir relações, espaços e objetos de interlocução; liberar os sentimentos; reconstituir os 
direitos civis eliminando a coação, as tutelas jurídicas e o estatuto de periculosidade; reativar uma base de rendimentos para poder ter acesso aos intercâmbios sociais. (Rotelli et al., 1990, p.32)

O sujeito (singularidade desejante) está excluído e/ou silenciado pelo dispositivo institucional totalitário (e asilar), que se pauta pelo discurso médico (Jorge, 1983). Sua emergência costuma ser apreendida no registro do desvio, do patológico, da subversão da ordem instituída. Seu advento é invariavelmente interpretado como um obstáculo que emperra o funcionamento adequado e efetivo do processo institucional. Ora, por mais que se negue, descarte o sujeito, ele persiste teimosamente em aparecer e tumultuar o ambiente, resiste ao próprio alijamento da cena institucional e manifesta-se nas disfunções e falhas que acometem as práticas microfísicas no contexto do estabelecimento. Ou como diz Goffman (1987, p.259), nas "fendas". 


\section{5 \\ ESTUdOS DE CASOS SINGULARES SOBRE ESTABELECIMENTOS TOTAIS E DISCIPLINARES}

Para a realização dessa investigação, utilizamos apenas a análise documental (Alves-Mazzotti, 1999, p.169). Usualmente, considera-se como documentos, qualquer registro escrito que possa ser usado como fonte de informações. Podem ser regulamentos, atas de reunião, cartas, diários, livros didáticos, arquivos, jornais, revistas etc. Estamos considerando os livros que analisamos como documentos que retratam a realidade de estabelecimentos fechados funcionando como instituições de internação totais e disciplinares. Acreditamos que eles são adequados para nossos objetivos, pois apresentam com detalhes os princípios e normas que regem o comportamento do grupo em sua vida institucional e as relações que se estabelecem entre os subgrupos (internados/equipe dirigente). Sobretudo, nos permitem compreender a lógica que organiza a internação enquanto estratégia institucional específica.

Nosso método de análise se baseia no caso singular. Para além da pretensão de dar conta de uma certa "objetividade empirista", o que buscamos foi, de modo coerente com a perspectiva institucionalista, a partir do material disponível, apreender a processualidade do fenômeno "estabelecimento de internação" em seus aspectos dinâmicos, essenciais e estruturais. Isso se demonstra efetivo quando o próprio leitor, a partir do conhecimento que tem sobre estabele- 
cimentos semelhantes, iluminado pela análise dialética e estrutural apresentada, pode se identificar com as descrições e análises explicitadas. É exatamente esse o efeito que produz a leitura de um caso singular bem estudado e corretamente apresentado.

É possível justificar uma reflexão e análise dos processos de funcionamento e de produção de subjetividade de um conjunto de instituições de internação com características semelhantes a partir de um único relato, se concebermos a hipótese de que não se trata de caso isolado, um caso idiossincrático, mas, pelo contrário, de um caso singular (Aguiar, 2002, p.139). Para Rey (1999, p.156, tradução nossa), "O estudo do caso singular adquire seu valor para a generalização pelo que é capaz de contribuir visando à qualidade do processo de construção teórica, não por seu valor em termos de quantidade. Esta afirmação é expressão de uma compreensão diferente do conceito de generalização...". ${ }^{1}$ Para Lacan (1980, p.55), o que faz a singularidade de um caso é o caráter manifesto, visível, das relações em jogo; seu valor de evidência é superior à própria demonstração abstrata. ${ }^{2}$ Segundo esses autores, um caso é considerável singular na medida em que encerra as informações essenciais

1 "El estúdio del caso singular adquiere su valor para la generalización por lo que es capaz de aportar a la cualidad del proceso de construcción teórica, no por su valor en términos de cantidad. Esta afirmación es expressión de una comprensión diferente del concepto de generalización..."

2 Quando Marx estudou o capitalismo, analisou apenas o caso inglês, pois era o mais avançado que havia na época. A partir dele, descreveu o que é o capitalismo. No campo da Psicanálise, podemos ainda pensar nas neuroses, psicoses e perversões como casos estruturalmente singulares: conhecendo bem um caso clínico, é possível entender quais são os elementos determinantes e constitutivos do fenômeno neurótico, psicótico ou perverso, inclusive considerando a singularidade individual. Foucault (1999b, p.156-60) afirma que o "caso clínico" é o modelo fundamental das Ciências Humanas, que são baseadas na tecnologia do exame. Também sabemos que Freud publicou apenas cinco casos clínicos, dos quais apenas três foram conduzidos por ele (Dora, Homem dos Lobos, Homem dos Ratos), que são casos singulares e paradigmáticos. Embora Lacan não se referia especificamente a "objetos institucionais", a análise institucional se inspira também na psicanálise para considerar as instituições como singularidades. 
sobre as características básicas do fenômeno que procuramos compreender e sobre os processos que aí estão em ação.

Para uma perspectiva institucionalista e dialética, certamente há lugar para a apresentação sistemática de um conjunto de observações de campo que podem lastrear as conclusões, mas não se trata de modo algum da mesma visada teórica do positivismo, nem se baseia numa suposta objetividade empirista e quantitativa. $\mathrm{O}$ pensamento positivista se caracteriza por uma pretensa objetividade atribuída aos fatos da realidade, exigindo por parte do pesquisador uma atitude de "neutralidade", visando não contaminar os "dados", que teriam uma objetividade intrínseca. Ora, não são exatamente os dados (em uma suposta pureza e neutralidade, que de resto não se verificam jamais de modo completo e exaustivo) aquilo que finalmente sustenta a veracidade das proposições conclusivas numa pesquisa institucionalista, mas sua verdade está em outra parte, mais especificamente, se localiza no plano do pensamento lógico, orientado por uma perspectiva ética radical.

A elaboração do pensamento corresponde a um processo dialético e permite a construção de categorias analíticas que alcançam o estatuto de conceitos estruturais, que por sua vez são dotados de forte capacidade explicativa e interpretativa. A construção desses conceitos fundamentais passa por uma imersão atenta num determinado campo de análise, o que pode ser realizado, por exemplo, por meio da observação participante, sendo possível ainda incluir uma coleta de dados quantitativos, a realização de entrevistas, bem como um levantamento bibliográfico e uma análise cuidadosa da literatura pertinente ao tema investigado. Mas não será nunca a simples soma de todos esses elementos quantitativos ou qualitativos aquilo que permitirá a formulação das proposições conclusivas. Não se trata de colecionar todo um conjunto de fragmentos aleatórios e dispersos, procurando ordená-los de modo a exercitar um certo associacionismo mecanicista. Categorias conceituais analíticas são fórmulas e construídas por meio um processo de trabalho dialético do pensamento. No presente estudo, duas categorias fundamentais empregadas são as de instituição total e de instituições disciplinares. 
O estudo de singularidade nos permite captar as determinações concretas constitutivas do fenômeno social: "O conhecimento produzido a partir de um sujeito, uma escola, um grupo, constitui-se, pois, em uma instância deflagradora da apreensão e do estudo de mediações que concentram a possibilidade de explicar a realidade concreta" (Aguiar, 2002, p.139). Como veremos, o conjunto a que pertencem os estabelecimentos que iremos analisar possui características e modos de funcionamento bastante congruentes com aquele que, já há bastante tempo, foi definido como instituições totais (Goffman, 1987; Benelli, 2002, 2003a) e disciplinares (Foucault, 1999b).

Feitas, entretanto, essas considerações sobre nosso método de estudo, não é demais assinalar que aceitamos perfeitamente que haja limites quanto à possibilidade de generalização de nossa pesquisa, primeiro porque acreditamos que, embora defendendo seu caráter de caso singular, nem por isso pensamos que fica superada por completo sua particularidade. Segundo porque os diversos atores institucionais dos relatos analisados expressam a experiência subjetiva de processos objetivos e subjetivos. Porém, devemos afirmar quanto ao segundo aspecto que, sendo a produção de subjetividade o foco de nossa análise, entendemos a subjetividade em sua dimensão objetiva, justamente na medida em que ela se transmite por palavras. Ela só pode expressar-se nas palavras e estas permitem a objetividade possível para a subjetividade (Lacan, 1998, p.105-6).

Pontuamos ainda que se a subjetividade se expressa com palavras, sua produção não precisa ser limitada ao registro do simbólico. De acordo com Foucault (1995, p.275), a subjetividade é produzida em práticas historicamente analisáveis, práticas de saber, de poder e práticas de si. O sujeito é constituído por práticas históricas específicas que podem ser discursivas, não discursivas e ainda por meio das tecnologias de si.

Nosso objetivo neste livro é realizar um estudo teórico sobre algumas instituições totais e disciplinares. Partindo do trabalho de Goffman (1987) sobre as instituições totais e do pensamento de Foucault (1999b) sobre as instituições disciplinares, apre- 
sentaremos algumas análises de casos da literatura que descrevem experiências em internatos escolares que funcionam como verdadeiras instituições totais e disciplinares. Por exemplo, utilizando os analisadores criados por Goffman e por Foucault, é possível analisar romances tais como O Ateneu, de Raul Pompéia, Doidinho, de José Lins do Rego, Em nome do desejo, de João Silvério Trevisan, e O jovem Törless, de Robert Musil. Trata-se de obras de épocas diferentes que descrevem a vida de indivíduos internados em instituições educativas. Em nome do desejo apresenta a vida num seminário católico. Pensamos que um colégio interno se enquadra na definição de instituição total e disciplinar, pois é um local fechado (claustro) no qual vivem muitos indivíduos que são submetidos à educação escolar formal. Acreditamos que esses autores descrevem microcosmos onde se desenvolve uma possível subjetividade específica, focalizando a vida institucional de um modo global.

Consideramos $O$ Ateneu um romance pleno de confissões autobiográficas de Raul Pompéia (1863-1895), escrito em 1888. É uma obra digna de análise, pois o internato escolar descrito pelo autor pode ser apreciado como um exemplo de uma instituição total em pleno funcionamento. A história do romance é a seguinte: o menino Sérgio, com onze anos, é internado por seus pais no colégio Ateneu com o objetivo de que ele complete sua formação escolar e prossiga com os estudos. Sérgio ainda é uma criança inocente do mundo e da realidade da vida e encontra no colégio interno colegas com diversos perfis, tanto em idade quanto em experiência e tendências. Há os pervertidos do ponto de vista moral e psicológico e os medrosos e apavorados. O drama do herói é grande, pois está inserido num universo particular e novo, e ele ainda não possui uma experiência da vida suficiente para compreender os tipos com os quais passa a conviver obrigatoriamente e para reagir ao meio ambiente corruptor e degradante que o cerca.

Os internados são governados pelo professor Aristarco, um empresário da educação, figura apresentada de modo caricaturesco, como grotesca, arbitrária e ridícula. Podemos acompanhar o menino Sérgio e seu mergulho no mundo institucional do internato escolar 
e verificar a presença e ação dos vários mecanismos que as instituições totais fazem funcionar com a finalidade de controlar e modelar o indivíduo. Pompéia descreve à exaustão a "carreira moral" de Sérgio, ao longo de páginas densas de introspeção psicológica.

As palavras finais de Menino de engenho (Rego, 1982) anunciam a ida de Carlinhos para o colégio interno. Em Doidinho (Rego, 1979) o autor escreve sobre sua experiência de aluno interno do Instituto Nossa Senhora do Carmo, em Itabaiana (Sergipe), estabelecimento dirigido pelo áspero Prof. Maciel, onde o autor de fato realizou seu curso primário. A compreensão integral da história de Doidinho exige a leitura prévia das peripécias do menino de engenho, pois são muitas as remissões a personagens, episódios e acontecimentos da primeira narrativa. Doidinho é um romance de internato. Uma vez segregado da vida paradisíaca que levava no engenho Santa Rosa do avô, Carlinhos é levado para o colégio interno e rapidamente despojado de suas prerrogativas pessoais, agravadas pelas ameaças do severo professor que não poupava castigos corporais. Em sua narrativa, podemos encontrar o testemunho de alguém que viveu, na carne, os processos educativos e reformadores próprios de uma instituição total.

Trevisan (1985) descreve a vida de sessenta meninos internados num seminário menor, onde vivem em tempo integral e realizam seus estudos escolares. O romance está escrito em forma de perguntas e respostas, imitando de propósito o catecismo antigo, no qual a doutrina cristã era apresentada nesse formato para ser decorada. Os personagens principais são Tiquinho e Abel, os heróis da trama. A vida institucional desse estabelecimento católico, que procura preparar candidatos ao sacerdócio ao mesmo tempo que administra a educação escolar formal, é descrita com uma riqueza de matizes e nela também podemos apreciar o modo de processamento típico de uma instituição total.

A subjetividade do aluno de um colégio interno seria caracterizada por uma identidade pessoal que é desmontada e reconstruída mediante processos de mortificações padronizadas do "eu". Acreditamos que geralmente se produzem resultados contrários aos ob- 
jetivos institucionais oficiais. $\mathrm{O}$ indivíduo renuncia a importantes aspectos de sua vida civil corrente ao ingressar no estabelecimento: perda autonomia pessoal, da liberdade para ir e vir, agir e decidir. Os anos de formação parecem ser um longo tempo no qual o indivíduo vive na condição de tutelado com relação a áreas fundamentais da vida pessoal. Poderemos verificar como esse processo se inicia e como o indivíduo internado no estabelecimento o vivencia.

A análise desse processo pode nos auxiliar a descobrir quais as disposições que instituições em geral deveriam observar e garantir, com a finalidade de que seus membros possam preservar sua identidade e autonomia pessoal. Ao que parece, as instituições totais, e o colégio interno como uma delas, têm "razões" que a equipe dirigente, com seus objetivos oficiais desconhece, e acaba produzindo indivíduos diferentes do que pretendia, de modo perverso e dissimulado. Acreditamos que provavelmente as práticas sociais reais que se desenvolvem na vida institucional são mais formadoras e modeladoras das subjetividades, do que seus projetos oficiais publicamente confessados.

\section{O colégio interno Ateneu como dispositivo disciplinar de produção de subjetividade ${ }^{3}$}

Consideramos O Ateneu, romance autobiográfico de Raul Pompéia (1863-1895), escrito em 1888, uma obra digna de análise, pois o internato escolar descrito pelo autor pode ser apreciado como exemplo de uma instituição total (Goffman, 1987) em pleno funcionamento. Pompéia (1997) rememora sua experiência escolar em termos de julgamento, em que a criança que ainda vive no adulto se levanta como um promotor que vai apresentar o elenco das humilhações e mortificações pelas quais foi obrigado a passar, num esforço de elaborar o passado e acertar suas contas com ele. As experiências traumáticas de internado são apresentadas de modo

3 Publicado originalmente como artigo: Benelli (2003a). 
crítico e ácido, através do narrador-personagem Sérgio (Nunes, 1986; Perrone-Moisés, 1988).

É surpreendente o quanto a narração de Pompéia (1997) pode ser lida a partir da perspectiva das instituições totais (Freitag, 2001; Perrone-Moisés, 1988). Evidentemente o autor não conhecia a teoria de Goffman (1987), mas pode experimentar pessoalmente os efeitos dessa máquina modeladora da subjetividade em si mesmo. Por isso, vamos tratar o texto de $O$ Ateneu como se fosse a gravação transcrita de um depoimento do autor. Em vez de parafrasear Pompéia (1997), preferimos lançar mão desse artifício e abusar da transcrição literal. Assim, não perdemos o interessante estilo de Pompéia e temos seu próprio testemunho de como realmente funciona uma instituição total, inclusive nos seus detalhes mais pitorescos e nos, especificamente, produtivos de subjetividade.

As análises de Goffman (1987) são extremamente agudas quando estudam as formas da organização do dispositivo institucional. Se ele não chega a articular uma microfísica do poder no contexto institucional e social, como faz explicitamente Foucault (1988, 1999a, 1999b), isso aparece numa leitura atenta em sua investigação do manicômio, da prisão e do convento. Goffman não pode conceituar o poder como relações de força em guerra; entretanto, é assim que sua análise o revela: produzindo no nível microfísico, exatamente do modo como o poder opera, para além dos limites teóricos e conceituais do autor.

Ao estudar as relações intrainstitucionais, ele oscila entre os planos molares e microfísicos: estabelece polaridades de poder e não poder nas quais, aparentemente, o poder seria privilégio de um grupo minoritário que infligiria a outro, mais numeroso, as consequências do abuso de tal poder. Mas também apresenta um poder que se estende como uma rede de pontos, relações móveis, resistências, efeitos repressivos, coercitivos e, inclusive, produtivos. Estão explícitas as mais diversas estratégias anônimas de poder (Benelli; Costa-Rosa, 2002).

Goffman (1987) analisa as práticas não discursivas, o não dito institucional, mas que é claramente visível (e não oculto) e, por- 
tanto, dizível e ele os articula com grande sutileza. Goffman faz os "detalhes" (Foucault, 1999b, p.120) aparentemente insignificantes do cotidiano institucional falarem e então percebemos o plano microfísico das relações intrainstitucionais superando a pura e simples dimensão organogramática (molar) e mergulhando nas diferentes estratégias nas quais o poder se ramifica, circula, domina e produz saberes, práticas, subjetividade. Das práticas não discursivas emergem concepções do objeto institucional e quais são os meios e instrumentos utilizados para trabalhá-lo. Normalmente, essa "teoria" e "técnica da prática" (pois "na prática a teoria é outra") costumam estar em franca contradição e conflito com o discurso institucional oficial (Goffman, 1987, p.70).

Goffman (1987) demonstra que há mais coisas em comum entre uma prisão e um convento, um asilo de loucos e um campo de concentração, entre um navio em alto mar e um internato escolar do que nos parece à primeira vista. Todos esses estabelecimentos utilizam mecanismos de segregação, estratificação social e modelagem da subjetividade, alternando punições, recompensas e a estratégia de dividir para reinar, que não são necessariamente diferentes das relações de dominação e subjetivação dos processos de poder em vigor em toda e qualquer sociedade. Mas nesses estabelecimentos, os mecanismos produtores de subjetividade são exacerbados por se tratar de situações extremas. De certa forma, são estabelecimentos específicos e como que purificados, revelando as engrenagens do poder de modo mais explícito e evidente, próprias para a pesquisa em laboratório.

A possibilidade de reduzir a identidade social de um sujeito a um atributo estigmatizante ou a um único e exclusivo papel, que representa a categoria social mais baixa dentro de um grupo fechado, é uma estratégia fundamental descoberta por Goffman (1987) nas comunidades fechadas, que ele denomina de instituições totalitárias. As análises de Goffman (1987) nos apresentam os procedimentos estruturados para a modelagem subjetiva e formas de repressão específicas efetuadas dentro dos muros das instituições totalitárias. Também nos revelam que formas de repressão mais 
gerais se dão na sociedade de massas, produzindo efeitos sobre indivíduos e categorias sociais inteiras.

\section{Dispositivos institucionais}

O dispositivo é uma grade de análise construída por Foucault (1988) para dar conta das conexões entre saber/poder. Engloba materiais heterogêneos, o dito e o não dito: arquitetura, discursos, teorias, técnicas, práticas, regras etc. A partir desses componentes díspares, podemos estabelecer um conjunto de relações flexíveis, reunindo-as num único aparelho, de modo a isolar um problema específico. Munido dessa ferramenta, é possível demarcar a natureza da relação que pode existir entre esses elementos discursivos e não discursivos, além de evidenciar a função estratégica do dispositivo, na medida em que responde à articulação entre produção de saber e modos de exercício de poder, dominantes em cada momento histórico.

Nesse sentido, podemos dizer que o poder disciplinar plasmou na sociedade moderna um dispositivo pedagógico autoritário, implementado em todas as suas minúcias no estabelecimento Ateneu, tal como afirma Foucault (1999b, p.145): "Assim é que o hospital-edifício se organiza pouco a pouco como instrumento de ação médica [...] um operador terapêutico. Como a escola-edifício deve ser um operador de adestramento, [...] um aparelho de vigiar".

Foucault (1984, 1988, 1999a, 1999b), demonstrou que as relações poder/saber, consideradas como práticas, realizam simultaneamente tanto a produção de conhecimentos específicos sobre o homem quanto uma produção técnica dele no interior de um determinado conjunto de instituições. É nessa articulação entre saber e poder, na intersecção dessas duas práticas sociais, que se produz o sujeito, pois quando se objetivam certos aspectos do homem é que há possibilidade de se organizar uma manipulação técnica institucionalizada dos indivíduos. E o contrário também se verifica, pois é necessário um conjunto de práticas institucionalizadas de manipulação dos indivíduos como condição para sua objetivação científica. Assim se produzem dispositivos psicológicos e pedagógicos. 
A subjetividade (modos de ser, sentir, pensar e agir constitutivos do sujeito em determinado momento histórico) é tecida, no contexto institucional pela rede de micropoderes que sustenta o fazer cotidiano (institucional), operando efeitos de reconhecimento/desconhecimento dessa ação concreta.

Uma instituição é uma prática social que se repete e se legitima enquanto se repete. As instituições implementadas em organizações e estabelecimentos não apenas realizam - quando realizam - os objetivos oficiais para os quais foram criadas, mas produzem determinada subjetividade. Sujeitos são fundados no interior das práticas, sujeitos ao mesmo tempo constituídos e constituintes do cotidiano institucional. O pensamento costuma reificar objetos e sujeitos que só existem enquanto se produzem e são produzidos dentro de determinadas práticas institucionais.

A produção de subjetividade remete fundamentalmente ao plano micropolítico, microfísico das relações instituintes e instituídas da formação no contexto institucional. Nessa perspectiva, as relações pedagógicas, terapêuticas, educativas entre a equipe dirigente e alunos internados não se configuram como relações estáticas entre polos constituídos, mas apresentam-se em permanente constituição e ordenação (plenas de vicissitudes) em constante transformação dos lugares e posições no interior das relações, numa pulverização dos lugares instituídos e instituintes.

Desse modo, não podemos conceber práticas e/ou sujeitos autônomos, pois toda prática é efetivada por relações nas quais se configuram sujeitos. Essa é a principal condição para que as instituições existam concretamente. A solidez institucional residiria nos vínculos entre os sujeitos que as fazem cotidianamente, vínculos invisíveis, microfísicos, que se plasmam em relações instituintes e instituídas no contexto institucional, podendo ser mapeadas a partir das forças e dos poderes moleculares que as permeiam.

A seguir, passaremos a descrever os operadores, os instrumentos técnicos institucionais presentes no colégio Ateneu, utilizados para a produção de subjetividade. Entendemos que os excertos do romance são expressamente analíticos por si mesmos, exemplifi- 
cando os diversos modos como o poder disciplinar se organiza no estabelecimento, produzindo realidade social: arquitetura, atores sociais, discursos, saberes e técnicas políticas de gerenciamento institucional humano.

\section{Operadores normalizadores constituintes do dispositivo institucional pedagógico}

O plano arquitetônico pode ser considerado como importante operador de normalização. Pompéia descreve a estrutura física do colégio: tratava-se de um grande conjunto arquitetônico, preparado para funcionar como moradia coletiva para crianças e adolescentes, um internato escolar. $\mathrm{O}$ estabelecimento era mantido pelo pagamento de mensalidades pelas famílias dos alunos ali internados, aparecendo como uma empresa privada cuja mercadoria era a educação escolar. A primeira característica totalitária do internato Ateneu é operar por subtração, utilizando a técnica da sequestração e do enclaustramento: privação da liberdade, incidindo diretamente sobre o corpo dos educandos. A autonomia pessoal é suprimida pela imposição de uma autoridade onipotente.

O Ateneu estava situado no Rio Comprido, extremo ao chegar aos morros. As eminências de sombria pedra e a vegetação selvática debruçavam sobre o edifício um crepúsculo de melancolia, resistente ao próprio sol a pino dos meios-dias de novembro. Esta melancolia era um plágio ao detestável pavor monacal de outra casa de educação, o negro Caraça de Minas. Aristarco dava-se palmas desta tristeza aérea - a atmosfera moral da meditação e do estudo, definia, escolhida a dedo para maior luxo da casa, como um apêndice mínimo da arquitetura. (Pompéia, 1997, p.36)

Quando Sérgio, acompanhado por seu pai, chegou ao colégio para se matricular e ingressar como internado no estabelecimento, o diretor levou-os para a "sala especial das visitas" (ibidem, p.46). Embora o autor não descreva essa sala, ela provavelmente 
não ficaria distante de um operador que Goffman (1987, p.91) descreve como parte do cerimonial institucional. Nessa mesma ocasião, Aristarco exibiu o colégio para Sérgio e seu pai. Pompéia (1997, p.46-7) descreve outros aspectos físicos do estabelecimento: o grande refeitório coletivo, a rouparia anexa ao lavatório, com centenas de bacias e, ao longo das paredes e pouco acima, num friso de madeira, os copos e as escovas de dente (ibidem, p.52). Prossegue ainda desenhando o estabelecimento.

A sala do professor Mânlio era ao nível do pátio, em pavilhão independente do edifício principal, com duas outras do curso primário, o alojamento da banda de música e o salão suplementar de recreio, vantajoso nos dias de chuva. Formando ângulo reto com esta casa, uma extensa construção de tijolo e tábuas pintadas, sala geral do estudo no pavimento térreo e dormitório em cima, concorria para fechar metade do quadrilátero do pátio, que o grande edifício completava, estendendo-se em duas alas, como os braços da reclusão severa. No fundo desta caixa desmedida de paredes, dilatava-se um areal claro, estéril, insípido como a alegria obrigatória, algumas árvores de cambucá mostravam, em roda, a folhagem fixa, com o verdor morto das palmas de igrejas, alourada a esmo da senilidade dos ramos que sofrem, como se não coubesse a vegetação no internato; a um canto, esgalgado cipreste subia até as goteiras, tentando fugir pelos telhados. (ibidem, p.55)

Natação chama-se o banheiro, construído num terreno das dependências do Ateneu, vasta toalha d'água ao rés da terra, trinta metros sobre cinco, com escoamento para o Rio Comprido, e alimentada por grandes torneiras de chave livre. O fundo, invisível, de ladrilho, oferecia uma inclinação, baixando gradualmente de um extremo para outro. Acusava-se mais ainda esta diferença de profundidade por dois degraus convenientemente dispostos para que tomassem pé as crianças como rapazes desenvolvidos. Em certo ponto a água cobria um homem. Ao longo do tanque, corria o muro divisório, além do qual ficava a chácara do diretor. À dis- 
tância, viam-se as janelas de uma parte da casa, onde às vezes eram recolhidos os estudantes enfermos, fechadas sempre as venezianas verdes. (ibidem, p.59-60)

[...] A cozinha do Ateneu, além dos alojamentos da copa, era espaçosa como um salão. As paredes cintilavam o trem completo de cobre areado, em linha as peças redondas como uma galeria de broquéis. No centro uma comprida mesa servia de refeitório à criadagem. (ibidem, p.105)

Os dormitórios apelidavam-se poeticamente, segundo a decoração das paredes: salão pérola, o das crianças policiado por uma velha, mirrada e má, que erigira o beliscão em preceito único disciplinar, olhos mínimos, chispando, boca sumida entre o nariz e o queixo, garganta escarlate, uma população de verrugas, cabeça penugenta de gipaeta sobre um corpo de bruxa; salão azul, amarelo, verde, salão floresta, dos ramos do papel, aos quais se recolhia a classe inumerável dos médios. O salão dos grandes, independentes do edifício, sobre o estudo geral, conhecia-se pela denominação amena de chalé. O chalé fazia vida separada e misteriosa. (ibidem, p.139)

No Ateneu havia também uma prisão, chamada "cafua", que Sérgio descreve com um "asilo de trevas e do soluço, sanção das culpas enormes" (ibidem, p.74-5). Trata-se de uma espécie de "solitária", lugar onde ficavam detidos os infratores da ordem institucional.

A prisão se localizava embaixo da casa. Fazia-se entrada pelo saguão cimentado dos lavatórios; sentia-se uma impressão de escuro absoluto; para os lados, à distância, brilhavam vivamente, como olhos brancos, alguns respiradouros gradeados daquela espécie de imensa adega. O chão era de terra batida, mal enxuta. Impressionava logo um cheiro úmido de cogumelos pisados. Com a meia claridade dos respiradouros, habituando-se a vista, distinguia-se no meio uma espécie de gaiola ou capoeira de travessões 
fortes de pinho. Dentro da gaiola um banco e uma tábua pregada, por mesa. Sobre a mesa um tinteiro de barro. Era a cafua. (ibidem, p.191)

O Ateneu é um microcosmo, um rico e complexo universo institucional. Os alunos internados são trezentos meninos e adolescentes. Há toda uma organização de lugares sociais, postos de comando, hierarquia, poder vigilante e normatizador. A equipe dirigente é formada pelo diretor, professores, inspetores e bedéis.

No plano psicossocial do estabelecimento institucional, podemos encontrar um conjunto de relações intrainstitucionais: há o mundo próprios dos alunos, com seu sistema de privilégios, punições e premiações normalizadoras e as válvulas de escape da pressão institucional. Há também o mundo da equipe dirigente, com seus próprios atores institucionais e procedimentos típicos de gestão e administração da vida institucional. Vamos apresentá-los a seguir.

\section{O mundo dos alunos internados}

De acordo com Goffman (1987, p.99-100) o grupo dos internados numa instituição total não deve ser considerado de modo homogêneo. No Ateneu, existem várias diferenças intragrupais: os alunos podem ser divididos entre vigilantes e vigiados (Pompéia, 1997, p.61-2), efeminados e másculos (ibidem, p.53, 183-4), fortes e fracos, belos e feios, angelicais e pervertidos, leais e traiçoeiros, bolsistas (ibidem, p.147) e pagantes.

Na descrição que Rebelo faz dos colegas internados para Sérgio, podemos apreciar a divisão sexual que se produzia num colégio unissexual.

"Conte como uma desgraça ter que viver com esta gente" - E esbeiçou um lábio sarcástico para os rapazes que passavam. - "Aí vão as carinhas sonsas, generosa mocidade... Uns perversos. Têm mais pecados na consciência que um confessor no ouvido; uma mentira em cada dente, um vício em cada polegada de pele. Fiem- 
-se neles. São servis, traidores, brutais, adulões. Vão juntos. Pensa-se que são amigos... Sócios de bandalheira! Fuja deles. Fuja deles. Cheiram a corrupção, empestam de longe. Corja de hipócritas! Imorais! Cada dia de vida tem-lhes vergonha da véspera. Mas você é criança; não digo tudo o que vale a generosa mocidade. Com eles mesmos há de aprender o que são... Aquele é o Malheiro... forte como um touro, todos o temem, muitos o cercam, os inspetores não podem com ele; o diretor respeita-o; faz-se vista larga para os seus abusos... Este que passou por nós, olhando muito, é o Cândido, com aqueles modos de mulher, aquele arzinho de quem saiu da cama, com preguiça nos olhos... ali vem o Ribas... feio, coitadinho! Como tudo, mas uma pérola. É a mansidão em pessoa. Primeira voz do Orfeão, uma vozinha de moça que o diretor adora. É estudioso e protegido. Faz a vida cantando como os serafins. Uma pérola... hoje é o primeiro dia, ali está de joelhos o Franco. Assim atravessa as semanas, os meses, assim o conheço nesta casa, desde que entrei. De joelhos espiando a culpa de uma raça. O diretor chama-lhe de cão, diz que tem calos na cara... Viu aquele da frente, que gritou calouro? Se um dissesse o que se conta dele... aqueles olhinhos úmidos de Senhora das Dores...Isto é uma multidão; é preciso força de cotovelos para romper... Os gênios fazem aqui dois sexos, como se fosse uma escola mista. Os rapazes tímidos, ingênuos, sem sangue, são brandamente impelidos para o sexo da fraqueza, são dominados, festejados, pervertidos como meninas ao desamparo..." (ibidem, p.53-4)

Sérgio, quando passou para o chalé, dormitório coletivo onde se alojam os maiores, descreveu a diversidade da população do colégio.

Depois disso, vinha a demografia especial da terceira classe, a distribuição por famílias regulares, ou por aproximações eventuais... Louvavam-se os exemplos de fidelidade; comentavam-se as traições; censuravam-se as tentativas de sedução; improvisava-se a teoria do lar e do leito; cantava-se o hino báquico dos caprichos 
volantes, do entusiasmo passageiro. Chamavam-me o Sérgio do Alves. Fazia-se a crítica dos novos sob um ponto de vista inteiramente deles. Apostavam a ver quem seria o primeiro, exigiam juramento de segredo, para passar adiante alguma história que tinham por sua vez jurado não contar a ninguém. Serviam-se mutuamente em pasto às boas risadas, anedotas espessas, com ou sem aplicação, conforme o pedido e o paladar do ensejo. Toda crônica obscura do Ateneu redigia-se ali, em termos explícitos e fortes, expurgada dos arrebiques de recato, de inverdade, pelo escrúpulo das comissões investigadoras. O Sílvino que se fosse! Não tinha nada com a conversa dos rapazes. Uma das melhores máximas do chalé era esta, característica: - Fica revogado o diretor. Havia o que afetava moderação no capricho, conhecendo o desvio em regra, como o ladrão sabe ser honesto no roubo; com o ar sério, espantadiço das femmes qui sortent; havia os ingênuos, perpetuamente infantis, não fazendo por mal, risonhos de riso solto, com o segredo de adiar a inocência intata através dos positivos extremos, apregoando-se por gosto, que não perdoavam à natureza o erro original da conformação: ah! Não ser eu mulher para melhor o ser! Estes faziam grupo à parte, conhecidos e satisfeitos com isto, protegidos por um favor de simpatia geral, inconfessado mas evidente, beneplácito perverso e amável de tolerância que favoneia sempre a corrupção como um aplauso. Eles, os belos efebos! exemplos da graça juvenil e da nobreza da linha. Às vezes traziam pulseiras; ao banho triunfavam, nus, demorando atitudes de ninfa, à beira d'água, em meio da coleção mesquinha de esqueletos sem carnes nas tangas de meia, e carnes sem forma. Havia os decaídos, portadores miseráveis de desprezo honesto, culpados por todos os outros, gastos às vezes antes do consumo, atormentados pela propensão de um lado, pela repulsa de outro, mendigos de compaixão sem esmola, reduzidos ao extremo de conformar-se deploravelmente com a solidão. Com estes em contraposição, os de orgulho masculino, peludos, morenos, nodosos de músculos, largos de ossada, e outros mirrados de malícia, insaciáveis de voz trêmula e narinas ávidas de bode, os gorduchos de beiço vermelho relaxado, fazendo praça de uma 
superioridade porque nem sempre zelaram antes da madureza das banhas. (ibidem, p.183-4)

No plano social do Ateneu, bem distante dos ideais propostos pelo regulamento, os critérios decisivos eram, em primeiro lugar, a força, em segundo, o prestígio da riqueza, que de fora vinha precisar os contornos das diferenças individuais. No plano afetivo, as matrizes dos gestos e das palavras eram a agressividade e a libido. Para observá-los, basta ler a descrição da fauna que rodeia Sérgio: destruída a fachada que a cerimônia inicial levantara, o menino percebeu espantado uma divisão entre fortes e fracos, que os impulsos da puberdade vinha colorir de matizes sexuais. As lideranças, já entronadas pelo poder da riqueza, se erguiam sobre argumentos musculares ou etários, onde os mais fortes, os mais velhos e calejados pela vida no colégio interno, podem dominar, oprimir e explorar os recém-chegados mais novos. "Tudo conspira contra os indefesos" (ibidem, p.63).

É um universo em que não há arestas, sequer humanidade. A força de um só encontra paralelo no poder de outro. Um equilíbrio pelo temor. É todo um complexo social que se faz presente, onde estes adolescentes são transformados em pequenas feras a fazerem parte de uma estranha matilha que se autodevora. Não há lugar para os puros (como Sérgio), para os fracos (como Franco). Num mundo assim concebido, a fraternidade passa a ser um indício de fraqueza. (Nunes, 1986, p.228)

\section{Sistema de privilégios: punições e premiações normalizadoras}

Podemos verificar no modo de funcionamento do Ateneu alguns elementos que consideramos como parte do sistema de privilégios (Goffman, 1987, p.49-58) que costuma existir nas instituições totais. São três os elementos básicos desse sistema: primeiro, um conjunto relativamente explícito e formal de prescrições e proibições 
que normatiza a conduta do internado. Essas regras costumam especificar com detalhes a rotina diária e austera da vida do internado. Segundo, contrastando com esse ambiente rígido, apresenta-se um pequeno número de prêmios ou privilégios claramente definidos, obtidos em troca de obediência, em ação e espírito, à equipe dirigente. Terceiro, o elemento castigo está integrado no sistema de privilégios. Os castigos são definidos como consequências de desobediência às regras. Um conjunto de tais castigos é formado pela recusa ou retirada, temporária ou permanente, de privilégios ou ainda pela eliminação do direito de adquiri-los.

Vamos enumerar e comentar a seguir alguns elementos do sistema de privilégios presentes no Ateneu. Havia um salão de estudos comum onde cada aluno possuía um espaço privativo pessoal.

Era a sala geral do estudo, à beira do pátio central, uma peça incomensurável, muito mais extensa do que larga. De uma das extremidades, quem não tivesse extraordinária vista custaria a reconhecer outra pessoa na extremidade oposta. À parede, em frente, perfilavam-se grandes armários com portas numeradas, correspondentes a compartimentos fundos: depósito de livros. Livros é o que menos se guardava em muitos compartimentos. O dono pregava um cadeado à portinha e formava o interior à vontade. [...] eu tive a ideia de armar em capela o compartimento do meu número. (Pompéia, 1997, p.79)

Esse espaço privado onde se podem guardar coisas pessoais de modo inviolável é considerado por Goffman (1987, p.204-8) como um direito que se perde numa instituição total. A posse de bens pessoais dificulta a eficiência institucional e os internados estão constantemente tentando garantir algum espaço onde possam manter bens pessoais a salvo dos demais, pois esses bens representam uma extensão do "eu", e os "reservatórios" de bens pessoais representam sua autonomia.

As saídas do colégio para os alunos eram de quinze em quinze dias. Havia também saídas extraordinárias, concedidas como prê- 
mio ou obséquio. Essas saídas eram obtidas mediante um sistema de recompensas pelo bom desempenho escolar, que funcionava como o sistema de privilégios visando a reorganização subjetiva do indivíduo: a criança deveria se tornar um "aluno", personagem institucional, corpo dócil e disciplinado, submisso à autoridade escolar. O professor dava cartão amarelo ao aluno que fazia bem uma lição. Dez cartões valiam um cartão impresso "boa nota”. Dez cartões de "boa nota" valiam um diploma que, por sua vez, tornava o aluno candidato a uma medalha de ouro ou de prata no final do curso. Pompéia (1997, p.97) avalia com ironia esse processo de recompensas, sem nenhum critério de justiça que o garanta. $\mathrm{O}$ cartão de "boa nota" podia ser usado para comprar uma saída extra. Sérgio nunca alcançava essas saídas de prêmio com seu mau desempenho escolar. Ainda havia um prêmio extraordinário para os alunos com excelente desempenho acadêmico: "Melhor que a prerrogativa do estudo era uma espécie de prêmio não catalogado nos estatutos, com que Aristarco gentilmente obsequiava os distintos. Levava-os a jantar em sua casa, uma honra!" (ibidem, p.175).

Também podemos verificar funcionando no Ateneu aquilo que Goffman (1987, p.54) denomina "sistema de ajustamentos secundários”: operador constituído por práticas que não desafiam diretamente a equipe dirigente, mas permite que os internados obtenham satisfações proibidas, ou consigam, por meios proibidos, as satisfações permitidas. $\mathrm{O}$ colégio não apenas fornece acesso à produção cultural social, como seu funcionamento disciplinar visa produzir um indivíduo sujeitado. Seu treinamento físico, seu comportamento cotidiano, sua atitude moral, suas disposições, tudo é assumido pela educação no internato: educação total que, mediante uma modelagem microfísica, busca uma produtiva recodificação da existência do indivíduo.

Pompéia (1997, p.99) comenta, de modo mais ou menos velado, como "a mocidade ia transigindo do melhor jeito com as bicudas imposições das circunstâncias" e que "as máximas, o diretor e a inspeção dos bedéis eram três espinhos", comparando o ambiente colegial com um ouriço invertido. 
Há outros elementos que podem ser considerados como parte do sistema de ajustamentos secundários, como a solidariedade entre os internados: "não denunciar nunca é preceito sagrado de lealdade no colégio" (ibidem, p.132). No caso dos cacos de vidro espalhados na piscina da natação (ibidem, p.88), Sérgio mente para o diretor, mas não consegue denunciar Franco. Quando Egbert fica envolvido no "caso Cândida", Sérgio sente-se solidário com ele e nunca toca no incidente desagradável com o amigo (ibidem, p.173).

Exemplo de ajustamento secundário pode ser encontrado ainda no fato de os alunos maiores escaparem escondidos do dormitório coletivo para tomar a fresca no jardim do diretor, durante à noite.

Com o tempo vim a descobrir que uma camarilha de espertos conseguira sofismar alguns paus da grade da última janela, três ou quatro leitos além do meu, e passavam de noite, quando o silêncio se fazia, a tomar fresco no jardim do diretor. Preferiam as noites escuras, que têm mais estrelas e mais segredo, e preferiam as noites de chuva, que em questão de fresco são decisivas. Desciam por uma corda de lençóis torcidos e voltavam às vezes como pintos, mas refrescados sempre. Por medida de prudência, não passavam mais de dois por noite, fazendo sentinela um na ausência do outro. (ibidem, p.185-6)

Quando Sérgio descobre a esperteza e a ousadia dos colegas, sente-se incomodado com a liberdade secreta deles, sente-se roubado de um privilégio. Pensa em entregar todos ao Silvino, inspetor encarregado do dormitório dos grandes (ibidem, p.182). Planejava

[...] trair merecidamente os traidores. Medi as objeções: além de feia delação de voluntário da espionagem, podia ser asneira. Talvez soubessem todos, menos eu, simplesmente por estar de pouco na terceira classe. Experimentei. Conservei-me acordado até a hora, com uma paciência e um esforço de caçador de emboscada. No momento flagrante, ergui-me na cama, esfregando os olhos, fingindo-me admirado. Não houve remédio senão iniciar-me. Os dois 
da noite contaram. O Malheiro era o chefe da troça, uma troça de nove, muito discretos, muito hábeis, também quem traísse apanhava. [...] Sempre que por acaso algum rapaz surpreendia os expedicionários da frescata, era incontinenti aliciado para as vantagens e sob as ameaças. (ibidem, p.186)

No Ateneu também havia mercado negro. Sérgio descreve com detalhes seu funcionamento:

Depois havia os jogos de parada, em que circulavam como preço as penas, os selos postais, os cigarros, o próprio dinheiro. As especulações moviam-se como o bem conhecido ofício das corretagens. Havia capitalistas e usurários, finórios e papalvos idiotas que se encarregavam de levar ao mercado com a facilidade de que dispunham fora do colégio, fornecimentos inteiros de Mallats e Guillots que os hábeis limpavam com a gentileza dos figurões da bolsa, e selos inestimáveis que os colecionadores desmereciam para tirar sem susto; fumantes ébrios de fumo alheio, adquirido facilmente no movimento da praça, repimpados à turca sobre os coxins da barata fartura. As transações eram proibidas pelo código do Ateneu. Razão demais para interessar. Da letra da lei, incubados sob a pressão do veto, surgiam outros jogos, mais expressamente característicos, dados que espirravam como pipocas, naipes em leque, que se abriam orgulhosos dos belos trunfos... roletas miúdas de cavalinhos de chumbo; uma aluvião de fichas em cartão, pululantes como os dados e coradas como os padrões do carteiro. A principal moeda era o selo. Pelo sinete da posta dava-se tudo. Não havia prêmios de lição que valessem o mais vulgar daqueles cupons servidos. Sobre este preço, permutavam-se os direitos do pão, da manteiga ao almoço, da sobremesa, as delícias secretas da nicotina, o próprio decoro pessoal de si. No comércio do selo é que fervia a agitação de empório, contratos de cobiça, de agiotagem, de esperteza, de fraude. Acumulavam-se valores, circulavam, frutificavam, conspiravam os sindicatos, arfava o fluxo, o refluxo das altas e das depreciações. Os inexpertos arruinavam-se, e havia banqueiros atilados, espapando banhas de prosperidade. (ibidem, p.132-5) 
O "microcosmo de atividade subterrânea" reunia-se no salão de estudos.

A sala geral do estudo, comprida, com as quatro galerias de carteiras e a parede oposta de estantes e a tribuna do inspetor, era um microcosmo de atividade subterrânea. Estudo era pretexto e aparência, as encadernações capeavam mais a esperteza do que os próprios volumes. A certas horas, reunia-se ali o colégio inteiro, desde os elementos de primeiras letras até os mais adiantados cursos. Agrupavam-se por ordem de habilitações; o abc diante da porta de entrada, à direita; à extrema esquerda, os filósofos, cogitadores do Barbe, os latinistas abalizados, os admiráveis estudantes do alemão e do grego. Baralhavam-se as três classes de idades... Dependia tudo do adiantamento. (ibidem, p.136)

Os alunos internados do Ateneu, para burlar a vigilância e se comunicarem, utilizavam

[... os telégrafos e a correspondência de mão em mão. Os fios telegráficos eram da melhor linha de Alexandre 80 , sutilíssimos e fortes, acomodados sob a tábua das carteiras, mantidas por alças de alfinete. Em férias desarmavam-se. Dois amigos interessados em comunicar-se estabeleciam o aparelho; a cada extremidade, um alfabeto em fita de papel e um ponteiro amarrado ao fio; legítimo Capanema. Tantas as linhas, que as carteiras vistas de baixo apresentavam a configuração agradável de cítaras encordoadas, tantas, que às vezes emaranhava-se o serviço e desafinava a cítara dos recadinhos em harpa de carcamano. (ibidem, p.136)

O telégrafo escrito tinha uma desvantagem: não servia no escuro da noite. Para resolver o problema, inventaram o "telégrafo-martelinho. Tantas pancadinhas, tal letra; tantas mais tantas menos, tais outras" (ibidem, p.137). Mas o inspetor encarregado da vigilância desconfiou dos ruídos que ouvia e destruiu, furioso, todo o equipamento dos garotos. "A violência não fez mais que aumentar o trá- 
fego dos bilhetinhos e suspender temporariamente a telegrafia. De mão em mão como as epístolas, corriam os periódicos manuscritos e os romances proibidos" (ibidem, p.137). Nesses periódicos, os alunos destilavam todo seu desprezo pelos colegas e autoridades do colégio. Os romances versavam sobre a luxúria e lutas pelo poder e dinheiro no mundo exterior.

Segundo Goffman, (1987, p.63-6), a vida no contexto institucional ainda produz alguns efeitos específicos no grupo dos internados. Efeitos que não estão previstos nos objetivos oficiais do estabelecimento e que acrescentam novos problemas para a equipe dirigente. Costumam surgir no grupo dos internados uma percepção particular do tempo, tal como nos mostra Sérgio.

O tédio é a grande enfermidade da escola, o tédio corruptor que tanto se pode gerar da monotonia do trabalho como da ociosidade. Tínhamos em torno da vida o ajardinamento em floresta do parque e a toalha esmeraldina do campo e o diorama acidentado das montanhas da Tijuca, ostentosas em curvatura toráxica e frentes felpudas de colosso; espetáculos de exceção, por momentos, que não modificavam a secura branca dos dias, enquadrados em pacote nos limites do pátio central, quente, insuportável de luz, ao fundo daquelas altíssimas paredes do Ateneu, claras da caiação, do tédio, claras, cada vez mais claras. Quando se aproximava o tempo das férias, o aborrecimento é maior. Os rapazes, em grande parte dotados de tendências animadoras para a vida prática forjivavam mil meios de combater o enfado e a monotonia. A folgança fazia época como as modas, metamorfoseando-se depressa como uma série de ensaios. (Pompéia, 1997, p.133)

Nessa vida reclusa, podemos constatar também o valor das distrações para os alunos internados.

A peteca não divertia mais, palmeada com estrépito, subindo como um foguete, caindo a rodopiar sobre o cocar de penas? Inventavam-se as bolas elásticas. Fartavam-se de borracha? Inventavam- 
-se pequenas esferas de vidro. Acabavam-se as esferas? Vinham os jogos de salto sobre um tecido de linhas de giz no soalho, ou riscadas a prego na areia, a amarela, e toas as suas variantes, primeira casa, segunda casa, terceira casa, descanso, inferno, céu, levando-se à ponta de pé o seixozinho chato em arriscada viagem de pulos. Era depois a vez dos jogos de corrida, entre os quais figurava notavelmente o chicote-queimado. Variavam os aspectos da recreação, o pátio central animava-se com a revoada das penas, o estalar elástico das bolas, passando como obuses, ferindo o alvo em pontaria amestrada, o formigamento multicor das esferas de vidro pela terra, com a gritaria de todas as vozes do prazer e do alvoroço (ibidem, p.133)

\section{O bode expiatório: válvula de escape das pressões institucionais}

Como todo sistema que vive oscilando à beira do desequilíbrio, o Ateneu também tem suas válvulas de escape. A figura agoniada de Franco, o rebelde permanentemente castigado e igualmente reincidente, é um exemplo de bode expiatório, no qual todos exorcizam a má consciência que os aguilhoa em meio a tantas contradições. Já no primeiro dia de aula, Franco estava de castigo, ajoelhado no chão (Pompéia, 1997, p.53). Rebelo comentou com Sérgio.

Se [Franco] não tivesse calos no joelho, não haveria canto do Ateneu que ele não marcasse com o sangue de uma penitência. $\mathrm{O}$ pai é do Mato Grosso; mandou-o para aqui com uma carta em que recomendava como incorrigível, pedindo severidade. O correspondente envia de tempos a tempos um caixeiro que faz os pagamentos e deixa lembranças. Não sai nunca... (ibidem, p.54)

[O Franco] sempre de penitência; em pé, cara contra a parede. Como Silvino dava-lhe as costas, divertia-se a pegar moscas para arrancar a cabeça e ver morrer o bichinho na palma da mão. Perguntei-lhe porque estava de castigo. Sem olhar, de mau modo: "Lá sei! disse ele. Porque me mandaram”. E continuou a pegar moscas. 
Franco era um rapazola de quatorze anos, raquítico, de olhos pasmados, face lívida, pálpebras pisadas. À fronte, com a expressão vaga dos olhos e obliquidade dolorida dos supercílios, pousava uma névoa de aflição e paciência, como se vê no Flos Sanctorum. A parte inferior do semblante rebelava-se; um canto dos lábios franzia-se em contração constante de odiento desprezo. Franco não ria nunca. Sorria apenas, assistindo a uma briga séria. Interessando-se pelo desenlace como um apostador de rinha, enfurencendo-o quando apartavam. Uma queda alegrava-o, principalmente perigosa... (ibidem, p.56)

Como os criminosos, os loucos e as prostitutas que são apontados e condenados pela repulsa geral, procurando de algum modo esconjurar as tentações de ódio e perversão que assediam as almas de todos, Franco era escarmentado pelo colégio em peso:

[...] Vivia isolado no círculo da excomunhão com que o diretor, invariavelmente, o fulminava todas as manhãs, lendo no refeitório perante o colégio as notas da véspera. Os professores já sabiam. À nota do Franco, sempre má, devia seguir-se especial comentário deprimente, que a opinião esperava e ouvia com delícia, fartando-se de desprezar. Nenhum de nós como ele! E o zelo do mestre cada dia retemperava o velho anátema. Não convinha expulsar. Uma coisa destas aproveita-se como um bibelô do ensino intuitivo, explora-se como a miséria do ilota, para a lição fecunda do asco. A própria indiferença da vítima é útil. Três anos havia que o infeliz, num suplício de pequeninas humilhações cruéis, agachado, abatido, esmagado, sob o peso das virtudes alheias mais que das próprias culpas, ali estava, - cariátide forçada no edifício de moralização do Ateneu, exemplar perfeito da depravação oferecido ao horror santo dos puros... 'Nenhum de nós como ele' - é o alívio dos alunos reunidos à hora em que se leem os boletins de notas. (ibidem, p.56)

Deixar-se morrer doente e preso na cafua foi alternativa que Franco encontrou para se vingar de todos e assim, alcançar a li- 
berdade. A estratégia de intransigência (Goffman, 1987, p.60) de Franco, pela qual desafiava intencionalmente o estabelecimento, negando-se de modo visível a cooperar com os dirigentes, produziu como efeito direto o zelo especial do diretor e de sua equipe para com o rebelde.

\section{mundo da equipe dirigente}

O diretor foi descrito de modo caricaturesco por Pompéia/Sérgio, realçando seus traços negativos. Aristarco, tipo consumado do empresário da educação, mestre na arte da pose e da autopromoção, vendia uma imagem idealizada do seu negócio.

Nas ocasiões de aparato é que se podia tomar pulso ao homem. Não só as condecorações gritavam-lhe do peito como uma couraça de grilos: Ateneu! Ateneu! Aristarco era todo um anúncio. Os gestos, calmos, soberanos, eram de um rei - o autocrata excelso dos silabários, a pausa hierática do andar deixava sentir o esforço, a cada passo, que ele fazia para levar adiante, de empurrão, o progresso do ensino público... (Pompéia, 1997, p.33)

Nos eventos públicos, exibições institucionais (Goffman, 1987, p.90ss.) que funcionavam como publicidade do estabelecimento, "Aristarco arrebentava de júbilo... distribuía-se numa ubiquidade impossível de meio ambiente..." deslocando-se por toda parte e falando com todos (Pompéia, 1997, p.39-40). Ele interrompia sua atividade de contador para receber os alunos que chegavam, dissimulando o empresário por trás da máscara do educador.

O diretor, no escritório do estabelecimento, ocupava uma cadeira rotativa junto à mesa de trabalho. Sobre a mesa, um grande livro abria-se em colunas maciças de escrituração e linhas encarnadas. Aristarco, que consagrava as manhãs ao governo financeiro do colégio, conferia, analisava os assentamentos do guarda-livros $[\ldots]$ (ibidem, p.45) 
A substância do diretor se encontrava na ostentação de si mesmo e na sede de lucro, pois o dinheiro era o absoluto da vida burguesa. Aristarco graduava os olhares, os sorrisos, as predileções no sistema de chefia, e até mesmo a escolha do futuro genro, pelos critérios de guarda-livros, como pontualidade no pagamento das mensalidades: "[...] Às vezes, uma criança sentia uma alfinetada no jeito da mão a beijar. Saía indagando consigo o motivo daquilo, que não achava em suas contas escolares... O pai estava dois trimestres atrasado" (ibidem, p.46).

Aristarco não era apenas o supervisor do seu colégio, ele era de fato um símbolo da administração e de todo o estabelecimento (Goffman, 1987, p.96). Ele se apresenta como uma figura do patriarcalismo, ícone de um regime paternalista em que o senhor de engenho e o dono de estância são substituídos por um diretor de colégio: "Não admira que em dias de gala, íntima ou nacional, festas do colégio ou recepção da coroa, o largo peito do grande educador desaparecesse sob constelações de pedraria, opulentando a nobreza de todos os honoríficos berloques" (Pompéia, 1997, p.32).

Nas cerimônias institucionais (Goffman, 1987, p.84ss.), o diretor se vestia bem, ficava comovido com a cerimônia, sorria, fazia discursos, dava parabéns, julgava as disputas, distribuía prêmios. Nessa atuação, desempenhava uma interação benigna e demonstrava interesse paternal para com os alunos e estes mostravam acanhamento, deferência e respeito. Isso é muito parecido com a representação de um senhor feudal desempenhando seu papel na festa anual em seu feudo, em plena sociedade moderna. "Ator profundo, realizava ao pé da letra, a valer, o papel diáfano, sutil, metafísico, de alma da festa e alma do seu instituto" (Pompéia, 1997, p.40).

O diretor se arvora de guia e senhor. E recebe o reconhecimento dos demais. Há no colégio um estranho processo de entetisação. Todos parecem acatar não apenas uma posição subalterna, mas sobretudo infamante. Portam-se como coisas, como animais em relação àquele que os une, que os mantém, que os maltrata. Não 
são apenas vítimas, logo metamorfoseiam-se em cúmplices. [...] Aristarco é o Ateneu. (Nunes, 1986, p.225)

Aristarco mantinha uma vigilância ostensiva sobre a vida dos internados, com traços maquiavélicos: dominava pelo terror de aparições súbitas e inadvertidas que fazia nos vários ambientes do colégio, salas de estudo, de aula, surpreendendo professores e alunos, procurando flagrantes.

[...] Por meio deste processo de vigilância de inopinados, mantinha no estabelecimento por toda parte o risco perpétuo do flagrante com uma atmosfera de susto. Fazia mais com isso que a espionagem de todos os bedéis. Chegava o capricho a ponto de deixar algumas janelas ou portas como votadas a fechamento para sempre, com o fim único de um belo dia abri-las bruscamente sobre qualquer maquinação clandestina da vadiagem. Sorria então no íntimo, do efeito pavoroso das armadilhas, e cofiava os majestosos bigodes brancos de marechal, pausadamente, como lambe o jaguar ao focinho a pregustação de um repasto de sangue. (Pompéia, 1997, p.83-4)

Auxiliando o diretor no cuidado da disciplina dos alunos no Ateneu, estavam os inspetores. João Numa, inspetor ou bedel, tratou Sérgio com delicadeza, quando ele era um novato no colégio (ibidem, p.49). O inspetor Silvino "fiscalizava o recreio, graduando a folgança, à mercê de um terrível canhenho. Sentava-se à entrada do portão do lavatório" (ibidem, p.55). Um inspetor vigiava o banho, "com a varinha destinada aos retardatários", mas ficava afastado e não via os abusos dos marmanjos com relação aos menores (ibidem, p.60). Inspetores vigiavam também as salas de aula (ibidem, p.68). Os inspetores vigiavam a distribuição da merenda, "prevenindo as espertezas inconvenientes" (ibidem, p.85), mas não observavam os maus-tratos dos colegas com relação a Franco, o bode expiatório do estabelecimento. Mais tarde, os inspetores comentariam com o diretor sobre a decadência de Sérgio e de sua proximidade com Franco (ibidem, p.86). "O policiamento dos dormitórios competia 
aos diversos inspetores, convenientemente distribuídos" (ibidem, p.139) Geralmente, os inspetores temiam os maiores e os deixavam em paz (ibidem, p.182).

Quanto aos horários e rotinas diárias, no Ateneu se despertava às cinco horas da manhã (ibidem, p.58). Nas épocas de maior calor, havia dois banhos por dia, na piscina da "natação" (ibidem, p.59). A disciplina determinava a divisão dos banhistas em três turmas, conforme as idades. Mas as turmas se misturavam, devido à falha na vigilância do inspetor de plantão, "[...] de sorte que ficavam expostos os mais fracos aos abusos dos marmanjos..." (ibidem, p.60).

Verificamos na descrição do banho comum que era oferecido aos internados um exemplo de exposição contaminadora. De acordo com Goffman (1987, p.31), elas podem ser físicas, sociais e psicológicas (apelidos, gozações), onde as fronteiras que o indivíduo estabelece entre seu ser e o ambiente são invadidas e sua pessoa pode ser sistematicamente profanada. Já não pode mais, como no mundo externo, manter objetos investidos por seu eu (seu corpo, suas ações imediatas, seus pensamentos e alguns de seus bens) fora de contato com coisas estranhas e contaminadoras. A vida em grupo exige contato mútuo e permanente exposição entre os internados.

[...] e cada banho era uma festa, naquela água gorda, salobra da transpiração das turmas precedentes, que as dimensões do tanque impediam a devida renovação; turbulento debate de corpos nus, estreitamente cingidos no calção de malha rajado a cores, enleando-se os rapazes como lampreias [...] os menores agrupados no raso, dando-se as mãos em cacho, espavoridos, se algum mais forte chegava. (Pompéia, 1997, p.59)

Ao meio-dia, Aristarco aproveitava a reunião de todos para a refeição e distribuía conselhos, advertências e reprimendas em massa por culpas coletivas. Realizava arrecadações de cigarros e também pequenos processos sumários, nos quais averiguava a autoria de delitos importantes, tais como: encher de papel picado uma sala, cuspir nas paredes, molhar a privada e outros mais graves (ibidem, 
p.83). Havia orações especiais em devoção à Virgem Maria no mês de maio (ibidem, p.80). Rezava-se o "hino do anjo da guarda" ao meio-dia (ibidem, p.81) e havia a oração da noite, aborrecida pelos meninos, exaustos do desgaste do dia (ibidem, p.82).

Os exercícios corporais efetuavam-se à tarde, uma hora depois do jantar, hora excelente, que habituava a digestão a segurar-se no estômago e não escorrer pela goela quando os estudantes se balançavam à barra-fixa, pelas curvas... Findos os exercícios, partia o professor Bataillard, e, guardados por dois inspetores, o Silvino e o João Numa, ou João Numa e o velho Margal, venerando inválido espanhol, querido de todos, ou o Margal e o Conselheiro, tínhamos os alunos, um prazo de recreio até o cair da noite. (ibidem, p.69)

Todas as atividades cotidianas eram prescritas pelo regulamento da casa. A vida dos alunos internados no Ateneu era governada por normas e regulamentos que previam prêmios e castigos, escritos em grandes quadros, espalhados pelas paredes do colégio (ibidem, p.48). Segundo Foucault (1999b, p.151ss.) e Goffman (1987, p.4958), existe um sistema de gratificação-sanção nas instituições totais, que realiza uma contabilidade penal, qualificando comportamentos e desempenhos a partir de dois valores opostos do bem e do mal, produzindo uma microeconomia dos privilégios e castigos. "[...] Todas as culpas são prevenidas, uma pena para cada hipótese...”, diz Aristarco para Sérgio e seu pai, no dia do ingresso no Ateneu (Pompéia, 1997, p.48). Mas ali “[...] não havia expressamente punições corporais” (ibidem, p.76). Visibilidade total e irrestrita é a nova estratégia utilizada pelo poder disciplinar para realizar o controlesem uso da violência ostensiva - para o exercício de uma vigilância produtiva. Cria-se um operador, "observatório" que obriga pelo jogo do olhar, um aparelho no qual técnicas óticas efetuam manobras de poder: olho do poder que vigia, produz, torna inteiramente visíveis os indivíduos sobre os quais incide (Foucault, 1999b).

O colégio funcionava dentro de uma verdadeira organização militar, na qual trezentos alunos internos eram repartidos em grupos 
de trinta, sob o comando direto de um vigilante, aluno do colégio. Os vigilantes eram escolhidos pelo diretor entre os alunos internos por seleção de aristocracia.

Esses inferiores da milícia da casa faziam-se tiranetes por delegação da suprema ditadura. Armados de sabres de pau com guardas de couro, tomavam a sério a investidura do mando e eram em geral de uma ferocidade adorável. Os sabres puniam sumariamente as infrações da disciplina na forma: duas palavras ao cerra-fila, perna frouxa, desvio notável do alinhamento. Regime siberiano, como se vê, do que resultava que os vigilantes eram altamente conceituados. (Pompéia, 1997, p.61-2)

Podemos ver no comportamento tirânico dos alunos vigilantes um claro exemplo do mecanismo da tiranização, incluindo a autoridade escalonada: qualquer pessoa da equipe dirigente tem o direito de impor disciplina a qualquer dos internados, o que aumenta claramente a possibilidade de sanção (Goffman, 1987, p.45), produzindo um clima decididamente aterrorizante e persecutório para os alunos.

\section{O microtribunal pedagógico}

Consideramos que um importante operador microfísico do Ateneu, instrumento de poder altamente mortificador, era o "livro de notas". Toda manhã, Aristarco abria um livro no qual os professores haviam feito anotações relativas ao aproveitamento dos alunos. Ele lia as notas e praticava assim uma clara violação de reserva de informações da vida escolar de cada aluno diante de toda a comunidade. Do livro aberto, se construía e se destruía, sem pruridos, a reputação dos alunos.

[...] Os vitimados fugiam, acabrunhados de vergonha, oprimidos sob o castigo incalculável de trezentas carinhas de ironia superior ou compaixão de ultraje. Passavam junto de Aristarco ao sair para a 
tarefa penal de escrita. O diretor, arrepiando uma das cóleras olímpicas que de um momento para outro sabia fabricar, descarregava com o livro às costas do condenado, agravante de injúria e escárnio à pena de difamação. O desgraçado sumia-se no corredor, cambaleando. (Pompéia, 1997, p.75)

Essa prática marcava de tal modo o indivíduo com um estigma de incapacidade, que acabava, por contágio de convicção, reforçando a imagem negativa do internado na opinião dos companheiros. O resultado era o da profecia autorrealizada, que se consumava quando o próprio indivíduo se convencia de sua inépcia e achava justa a condenação. Evidentemente, a leitura cotidiana do livro de notas funciona como o "circuito" (Goffman 1987, p.40) e como vigilância, exame e sanção normalizadora (Foucault, 1999b). Podemos falar de uma "terapeutização da pedagogia" com finalidade normatizante e normalizadora.

Goffman (1987, p.40) descreve o "circuito" como uma perturbação na relação usual entre o ator individual e seus atos. Uma agência cria uma resposta defensiva no internado e depois utiliza essa resposta para seu ataque seguinte. $\mathrm{O}$ indivíduo descobre que sua resposta protetora diante de um ataque à sua pessoa falha na situação, pois não pode defender-se da forma usual ao tentar estabelecer uma distância entre a situação mortificante e seu ego. Como as esferas da vida estão interligadas no contexto institucional, a conduta do internado numa área de atividade é lançada contra ele pelos dirigentes, como comentário e verificação de sua conduta em outro contexto.

O "circuito" inclui a "tiranização" (Goffman, 1987, p.41) do indivíduo mediante um processo de infantilização social que retira da pessoa sua autonomia, liberdade de ação e capacidade de decisão, perturbando decididamente sua autonomia civil; a obrigação de pedir permissão ou instrumentos para realizar atividades secundárias que o indivíduo pode executar sozinho no mundo externo, produz submissão e infantilização; o "processo de arregimentação" (ibidem, p.44), que indica a obrigação de executar a atividade regulada em uníssono com grupos de outros internados e, ainda, um 
"sistema de autoridade escalonada", no qual qualquer pessoa da equipe dirigente tem o direito de impor disciplina a qualquer dos internados, o que aumenta claramente a possibilidade de sanção.

Com exceção dos privilegiados, os vigilantes, os amigos do peito, os que dormiam à sombra de uma reputação habilmente arranjada por um justo conchavo de trabalho e cativante doçura, havia para todos uma expectativa de terror antes da leitura das notas. O livro era um mistério. (Pompéia, 1997, p.75)

A leitura matinal do livro de notas se assemelhava a um processo judicial que apresentava e denunciava culpados, fustigando-os com o vexame da humilhação pública e o juiz implacável, encarnado pelo diretor, sentenciava o faltoso imediatamente. A tecnologia disciplinar do livro de notas ensinava os internados a viverem sob condições de exposição iminente, sujeitos a grandes flutuações de consideração, com pouco controle da obtenção ou perda de tal consideração, sendo essa uma etapa importante na carreira moral e na socialização dos internados. O fato de ter seu desempenho acadêmico elevado à categoria máxima e definidora de sua pessoa, seu fracasso ou sucesso escolar submetido à constante monitoração e avaliação moral, impede que o indivíduo conserve opiniões firmes a respeito de seu autoconceito.

O internado aprende que as degradações e reconstruções do "eu" não devem ser muito consideradas, e ao mesmo tempo aprende que a equipe dirigente e os outros internados estão preparados para interpretar, com certa indiferença, as destruições e reconstruções do "eu". Aprende que uma imagem defensável do "eu" pode ser vista como algo fora de si mesmo e que pode ser construída, perdida e reconstruída - tudo isso com certa rapidez e justiça. (Goffman, 1987, p.139-40)

Esse contexto moral, pouco sério e exagerado, no qual a construção do autoconceito e sua destruição eram transformadas num jogo 
indiscreto e impudico, produzia no internado uma desmoralização, ao ensinar-lhe a viver esse processo de forma incessante. $\mathrm{O}$ fato de que o "eu" do indivíduo fosse tratado como uma cidade aberta e não como uma fortaleza particular e inviolável, produzia uma fadiga e um relaxamento moral. $\mathrm{O}$ internado aprendia que podia sobreviver e agir de uma forma que o estabelecimento considera negativo. Sérgio nos oferece um exemplo disso com sua prostração e impotência nas quais se abandonou (Pompéia, 1997, p.77ss.). Não importava quão baixo ele estivesse na escala das considerações institucionais, como era o caso de Franco, de um modo mais radical, isso não era capaz de excluí-lo da comunidade dos internados. Ao aceitar a interpretação institucional a seu respeito, o indivíduo podia adquirir a intenção de emendar-se, corrigir-se e solicitar da equipe dirigente auxílio, compreensão, privilégios e perdão, com o objetivo de perseverar nessa nova atitude. Mas não foi isso o que aconteceu com Sérgio. Nesse momento, ele vivia uma temporada de intenso fervor religioso (ibidem, p.93) e, depois de rebelar-se contra a tirania dos vigilantes, passou a utilizar a estratégia da "viração": trata-se de uma combinação oportunista de ajustamentos secundários, conversão, colonização e lealdade aos colegas, de modo a obter, dentro da situação específica, uma possibilidade máxima de evitar sofrimentos físicos ou psicológicos (ibidem, p.98).

Cada carreira moral, e, atrás desta, cada "eu", se desenvolve dentro dos limites de um sistema institucional, seja um estabelecimento social, seja um complexo de relações pessoais e profissionais. Portanto, o "eu" pode ser visto como algo que se insere nas disposições que um sistema social estabelece para seus participantes. Nesse sentido, o "eu” não é uma propriedade da pessoa a que é atribuído, mas reside no padrão de controle social que é exercido pela pessoa e por aqueles que a cercam. Pode-se dizer que esse tipo de disposição social não apenas apoia, mas constitui o "eu”. (Goffman, 1987, p.142)

Geralmente as pessoas exigem proteção e aceitação tácita para a versão de si mesmas que apresentam aos demais. $\mathrm{O}$ afastamento 
dessa proteção do autoconceito forma um aspecto sistemático e intencional no funcionamento do Ateneu, cristalizado no livro de notas que o diretor lia a cada manhã perante a comunidade escolar.

\section{O microtribunal inquisitorial}

No Ateneu realizou-se um processo inquisitorial, que denominamos "caso Cândida". Toda a comunidade escolar ficou em polvorosa diante da ameaça que pairava sobre todos, gerando um clima altamente persecutório. Um dos alunos, Cândido, havia enviado uma carta de amor para outro colega e assinado "Cândida".

Aristarco discursou e trovejou sobre a comunidade escolar na hora do jantar: "Tenho a alma triste, Senhores! A imoralidade entrou nesta casa! Recusei-me a dar crédito, rendi-me à evidência..." Com todo o vigor tenebroso dos quadros trágicos, historiou-nos uma aventura brejeira. Uma carta cômica e um encontro marcado no jardim. "Ah! Mas nada me escapa... tenho cem olhos. Se são capazes, iludam-me! Está em meu poder um papel, monstruoso corpo de delito! Assinado por um nome de mulher! Há mulheres no Ateneu, meus senhores! Esta mulher, esta cortesã fala-nos da segurança do lugar, do sossego do bosque, da solidão a dois... um poema de pouca vergonha! É muito grave o que tenho a fazer. Amanhã é o dia da justiça! Apresento-me agora para dizer somente: serei inexorável, formidando! E para prevenir: todo aquele que direta ou indiretamente se acha envolvido nessa miséria... tenho a lista dos comprometidos... e que negar espontâneo auxílio ao procedimento da justiça, será reputado cúmplice e como tal: punido!" Este convite era um verdadeiro arrastão. Remexendo a gaveta da consciência e da memória, ninguém havia, pode-se afirmar, que não estivesse implicado na comédia colegial dos sexos, ao menos pelo enredo remoto do ouvi dizer. Ouvir dizer e não denunciar logo era um crime dos grandes na jurisprudência costumeira. A devassa prometida fazia alarma geral. Como prever as complicações do processo? Como adivinhar o segredo tremendo da lista? 
Aristarco ufanava-se de perspicácia de inquisidor. Sob a saraivada das perguntas, ameaças, promessas, o interrogado perturbava-se, comprometia-se, entregava-se e traía os outros; nos processos de gabinete, os fatos floresciam em corimbo, frutificavam em cacho; a pesquisa de uma culpa descobria três, sem contar as ramificações da cumplicidade de outiva. Ao retirar-se, o diretor deixou na sala uma estupefação de pavor. (Pompéia, 1997, p.161)

Sérgio também temeu e se sobressaltou, pois suas relações pessoais com o diretor já eram complicadas e se agravaram ainda mais a partir de um incidente que ocorreu entre ambos, logo depois de uma luta do menino com seu protetor, e quase namorado, Bento Alves (ibidem, p.162-3). Sua persecutoriedade não era infundada. Sérgio relatou com detalhes a sessão solene do processo.

Não foi possível dormir tranquilo. À hora do primeiro almoço, como prometera, Aristarco mostrou-se em toda sua grandeza fúnebre dos justiçadores. De preto. Calculando magnificamente os passos pelos do diretor, seguiam-no em guarda de honra muitos professores. À porta fronteira, mais professores de pé e os bedéis ainda, e a multidão bisbilhoteira dos criados. Tão grande a calada, que se distinguia nítido o tique-taque do relógio, na sala de espera, palpitando os ansiados segundos. Aristarco soprou duas vezes através do bigode, inundando o espaço com um bafejo todo-poderoso. E sem exórdio: "Levante-se, Sr. Cândido Lima! Apresento-lhe, meus senhores, a Sra . D. Cândida”, acrescentou com uma ironia desanimada. "Para o meio da casa! E curve-se diante dos seus colegas!" Cândido era um grande menino, beiçudo, louro, de olhos verdes e maneiras difíceis de indolência e enfado. Atravessou devagar a sala, dobrando a cabeça, cobrindo o rosto com a manga, castigado pela curiosidade pública. "Levante-se, Sr. Emílio Tourinho..." Tourinho era um pouco mais velho do que o outro, porém mais baixo; atarracado, moreno, ventas arregaladas, sobrancelhas crespas, fazendo um só arco pela testa. Nada absolutamente conformado para um galã; mas era com efeito o amante. "Venha ajoe- 
lhar-se com o companheiro. Agora, os auxiliares..." Desde às cinco horas da manhã trabalhava Aristarco no processo. O interrogatório, com o apêndice das delações da polícia secreta e dos tímidos, comprometera apenas dez alunos. À chamada do diretor, foram deixando os lugares e postando-se de joelhos em seguimento dos principais culpados. "Estes são os acólitos da vergonha, os co-réus do silêncio!" Cândido e Tourinho, braço dobrado contra os olhos, espreitavam-se a furto, confortando-se na identidade da desgraça, como Francesca e Paolo no inferno. Prostrados os doze rapazes perante Aristarco, na passagem alongada entre as cabeceiras das mesas, parecia aquilo um ritual desconhecido de noivado: à espera de benção para o casal à frente. Em vez de benção chovia a cólera. "Esquecem pais e irmãos, o futuro que os espera, e a vigilância inelutável de Deus!... Na face estranhada não lhes pegou o beijo das mães... caiu-lhes a vergonha como um esmalte postiço... Deformada a fisionomia, abatida a dignidade, agravam ainda a natureza; esquecem as leis sagradas do respeito à individualidade humana... E encontram colegas assaz perversos, que os favorecem, calando a reprovação, furtando-se a encaminhar a vingança da moralidade e a obra restauradora de justiça!..." O diretor derramou toda sua fúria sobre os pobres condenados. Depois, conduzidos pelos inspetores, saíram os doze como uma leva de convictos para o gabinete do diretor, onde deviam ser literalmente seviciados, segundo a praxe da justiça do arbítrio. Consta que houve mesmo pancada de rijo. Os condenados negaram, depois. Em todo caso, era de efeito o simples consta, engrandecido pela refração nebulosa do boato. Concluída a chamada dos indiciados, a sala inteira respirou desafogo. No recreio, a rapaziada dispersou-se com gritos festivos. (ibidem, p.164-6)

Vemos assim como funciona no Ateneu um "mecanismo penal" de efeitos microfísicos: uma máquina kafkiana de punir que "é beneficiada por uma espécie de privilégio de justiça, com suas leis próprias, suas instâncias de julgamento, estabelecendo infrapenalidades" (Foucault, 1999b, p.149). 


\section{A carreira moral de Sérgio no internato escolar Ateneu ${ }^{4}$}

Depois de estudar o colégio Ateneu como dispositivo pedagógico, vamos tomar o romance de Raul Pompéia como campo de análise para acompanharmos o menino Sérgio e seu mergulho no mundo institucional do internato escolar e verificar a presença e ação dos vários mecanismos que as instituições totais fazem funcionar com a finalidade de controlar e modelar e produzir o indivíduo. Pompéia descreve à saciedade a "carreira moral" de Sérgio, ao longo de páginas densas de introspecção psicológica.

O ingresso numa instituição total implica mudanças significativas na existência do indivíduo, tendo início sua "carreira moral" (Goffman, 1987, p.111) como internado. "O novato chega ao estabelecimento com uma concepção de si mesmo que se tornou possível por algumas disposições sociais estáveis no seu mundo doméstico", afirma Goffman (1987, p.24). Já no seu ingresso começa a ser despido desses referenciais identificatórios, começa a passar por uma série de rebaixamentos, degradações, humilhações e profanações do conceito que tinha de si mesmo. Sua "carreira moral" vai passar por mudanças radicais e progressivas, suas crenças a respeito de si mesmo e sobre as pessoas significativas para ele são questionadas, entram em crise e começam a desmoronar. Trata-se de um processo de institucionalização do indivíduo. Neste estudo, vamos utilizar a ideia de "carreira moral" para mapear a experiência de internação que Sérgio vivencia no Ateneu.

\section{A vida de Sérgio antes do ingresso no Ateneu}

O romance se abre com as palavras do pai de Sérgio: "Vais encontrar o mundo", disse-me meu pai, à porta do Ateneu. "Coragem para a luta". E tudo o que se segue sublinha a ruptura com a vida e o ambiente social representado pela vida familiar, única referência

4 Publicado originalmente como artigo: Benelli (2004c). 
de Sérgio, até aquele momento. A vida no seio da família é definida como "estufa de carinho" (Pompéia, 1997, p.30) e "conchego placentário" (ibidem, p.31). O dado original da ruptura com sua vida cotidiana e "normal" foi matriz de infelicidade para o adulto Pompéia-Sérgio, que não perdoou à vida o ser lançado à indiferença cruel da escola e à convivência com os mais fortes.

Em sua fase de pré-internado, Sérgio vivia com a família e gozava de um status civil correspondente à sua idade, nível socioeconômico e posição na constelação familiar. Antes de ingressar no Ateneu, ele já havia recebido alguma educação escolar em regime de externato, iniciando sua alfabetização (ibidem, p.30), depois teve um professor particular (ibidem, p.31).

Inicialmente, Sérgio, deslumbrado pelas festividades que presenciou em duas visitas que fez ao Ateneu (ibidem, p.33-9), sonha ingressar na escola e triunfar como um bravo, movido por ideais de vitória:

Mas um movimento animou-me, primeiro estímulo sério da vaidade: distanciava-me da comunhão da família, como um homem! Ia por minha conta empenhar a luta dos merecimentos; e a confiança nas próprias forças sobrava. Quando me disseram que estava a escolha feita da casa de educação que me devia receber, a notícia veio achar-me em armas para a conquista audaciosa do desconhecido. (ibidem, p.31-2)

Sérgio e seu pai foram recebidos para um jantar na casa do diretor, antes do ingresso do menino no Ateneu. O garoto estremeceu, quando o diretor lhe afagou a cabeça e falou com ele.

"Como se chama o amiguinho?" - perguntou-me o diretor. "Sérgio..." - dei o nome todo, baixando os olhos e sem esquecer o "seu criado" da estrita cortesia. "Pois meu caro sr. Sérgio, o amigo há de ter a bondade de ir ao cabeleireiro deitar fora esses cachinhos..." Eu tinha os cabelos compridos, por um capricho amoroso de minha mãe. O conselho era visivelmente salgado de censura... (ibidem, p.43) 
Podemos observar aqui a primeira indicação de uma mudança na aparência pessoal daquele que vai ser internado no estabelecimento escolar. O corte de cabelos de Sérgio é o símbolo das transformações pelas quais vai passar, ao deixar o ambiente doméstico. "É a infância que ali fica, nos cabelos louros...", comenta Ema, esposa de Aristarco, colhendo os cabelos do menino entre os dedos e sugerindo que ele os oferecesse à sua mãe como recordação (ibidem, p.44).

\section{O primeiro dia no internato}

Sérgio ingressou no colégio interno voluntariamente e pleno de expectativas otimistas. Depois dos acertos na secretaria, ao menino foi designado um lugar no dormitório dos médios; havia também dormitórios para os menores e para os grandes, todos coletivos. As roupas de Sérgio foram guardadas na "rouparia", na gaveta que lhe foi indicada, de número 54 .

Quando meu pai saiu, vieram-me lágrimas, que eu tolhi a tempo de ser forte. Subi ao salão azul, dormitório dos médios onde estava minha cama; mudei de roupa, levei a farda ao número 54 do depósito geral, meu número. Não tive coragem de afrontar o recreio. Via de longe os colegas, poucos àquela hora, passeando em grupos, conversando amigavelmente, sem animação, impressionados ainda com as recordações de casa; hesitava em ir ter com eles, embaraçado da estreia das calças longas, como um exagero cômico, e da sensação de nudez à nuca, que o corte recente dos cabelos desabrigara em escândalo. (ibidem, p.49)

Um dos inspetores o animou a entrar em contato com os outros meninos. Observamos que, uma vez no internato, o menino se distanciou e procurou permanecer fora de contato com os demais, numa estratégia exploratória de conhecimento da nova realidade. Podemos especular que se tratava de uma criança tímida, pouco desenvolvida para seus onze anos (ibidem, p.43), bonita e evasiva, 
mais propensa para o medo do que para a assertividade. Sérgio foi solicitado pelos colegas internados a sair desse anonimato e ausência, implicando-se na interação social convencional na comunidade escolar. Quando Sérgio aceitou sua nova posição de internado, começou a passar por um processo que é comum a toda uma classe de estabelecimentos segregadores - cadeias, conventos, mosteiros, campos de concentração ou de trabalho forçado etc. - nos quais o indivíduo passa um longo período de sua vida confinado no estabelecimento e vive rotineiramente sob a disciplina e vigilância de uma equipe dirigente, na companhia de um grupo de companheiros que possuem igual status institucional (Goffman, 1987).

O novato no estabelecimento começa a perceber que está despojado de muitas de suas defesas, satisfações, afirmações e apoios costumeiros. Agora, ele está sujeito a um conjunto relativamente completo de experiências de mortificações (Goffman, 1987, p.24): restrição do movimento livre para ir e vir, vida comunitária compulsória, autoridade difusa de toda uma escala de pessoas etc.

Na sua primeira aula no internato (Pompéia, 1997, p.49), Sérgio foi apresentado pelo professor Mânlio aos seus colegas, sendo recomendado a um aluno mais velho e sério da turma, o Rebelo, aluno estudioso, atento e que usava óculos por causa de dificuldades visuais. $\mathrm{O}$ autor descreveu seus companheiros de classe (ibidem, p.49-51) de modo irônico e sarcástico, ressaltando os defeitos dos colegas, de uma perspectiva pessoal, nitidamente elitista.

Entretinha-me a espiar os companheiros, quando o professor pronunciou o meu nome. Fiquei tão pálido que Mânlio perguntou-me, brando, se queria ir à pedra. Precisava examinar-me. De pé, vexadíssimo, senti abrumar-me a vista, numa fumaça de vertigem... (ibidem, p.51)

Sérgio desmaiou, sentindo-se sob o olhar dos colegas. O menino despertou na rouparia, sob os cuidados de Rebelo: "Rebelo retirou-se e eu, em camisa, acabrunhado, amargando o meu desastre, enquanto o roupeiro procurava o gavetão 54 , fiquei a considerar a 
diferença daquela situação para o ideal de cavalaria com que sonhara assombrar o Ateneu" (ibidem, p.51).

Ainda na rouparia, Sérgio se entreteve com um folheto pornográfico, que devia pertencer ao roupeiro. Mais uma decepção e ao mesmo tempo um símbolo dos aspectos eróticos da vida íntima do internado, com os quais logo Sérgio iria se enfrentar (ibidem, p.52).

Ao sair para o pátio, Sérgio conversou com Rebelo que lhe descreveu os colegas do internato, carregando nas tintas e apresentando-os negativamente. Sérgio foi perseguido por alguns de seus colegas de internato (ibidem, p.54), que o provocaram ostensivamente e o obrigaram a reagir e revidar com violência. Isso pode ser entendido como uma tentativa, por parte dos veteranos, de obter a cooperação inicial do novato, de tentar submetê-lo com o objetivo de se aproveitarem dele posteriormente. "Faça-se forte aqui, faça-se homem. Os fracos perdem-se" - havia lhe recomendado outro colega, o Rebelo (um autêntico convertido, que assume em sua fala, o discurso oficial da escola) - "Faça-se homem, meu amigo! Comece por não admitir protetores” (ibidem, p.54).

Quando Rebelo foi para a aula, Sérgio viu-se sozinho. Ele permaneceu na órbita de um dos inspetores que "fiscalizava o recreio, graduando a folgança...um pouco além da cadeira do Silvino, fiquei a salvo" (ibidem, p.55). Os recém-chegados eram chamados de calouros ou novatos, e segundo Sérgio, "eram os pobres novatos que os veteranos sovavam à cacholeta, fraternalmente" (ibidem, p.56) durante os recreios coletivos onde todos se misturavam. Vemos que depois da admissão oficial, Sérgio passou a ficar exposto aos usuais processos de mortificação do "eu” que Goffman (1987, p.24ss.) descreve com clareza. Sérgio procurou se aproximar de Franco, bode expiatório do colégio, que estava de castigo novamente, mas este não lhe deu atenção.

Provocado por Barbalho, um colega de internato que o perseguiu durante este dia, Sérgio acabou tendo uma briga com ele.

Foi à noite, pouco antes da ceia. Estávamos a um canto mal iluminado do pátio, quase a sós. O biltre reconheceu-me e arrega- 
nhou uma inexprimível interjeição de mofa. Não esperei por mais. Estampei-lhe uma bofetada. Meio segundo depois, rolávamos na poeira, engalfinhados como feras. Uma luta rápida. Avisaram-nos que vinha o Silvino. Barbalho evadiu-se. Eu verifiquei que tinha o peito da blusa coberto de sangue que me corria do nariz. Uma hora mais tarde, na cama de ferro do salão azul, compenetrado da tristeza de hospital dos dormitórios, fundos na sombra do gás mortiço, trincando a colcha branca, eu meditava o retrospecto do meu dia. (Pompéia, 1997, p.57)

Sérgio, decepcionado, meditou sobre o contraste entre suas aspirações ideais iniciais e a realidade do internato de que tivera uma amostra em seu primeiro dia. Era assim selvagem e cruel o colégio. Sérgio ficou sozinho e se sentiu abandonado, uma vez perdidas as ilusões idealizadas da vida nova no internato.

[...] Era o ermo. E, na solidão, conspiradas as adversidades de toda a espécie, falsidade traiçoeira dos afetos, perseguição da malevolência, espionagem da vigilância; por cima de tudo, céu de trovão sobre os desalentos, a fúria tonante de Júpiter-diretor, o tremendo Aristarco dos momentos graves. (ibidem, p.58)

Sérgio chorou sua solidão, abandono e tristeza, mergulhando na mais completa anomia.

\section{Estratégias adaptativas}

O internado precisa se adaptar aos processos de admissão, mortificação e ao sistema de privilégios da vida institucional (Goffman, 1987). Tal adaptação pode produzir-se de diferentes modos e o internado empregará diversas táticas adaptativas em distintos momentos de sua "carreira moral", podendo também alternar entre várias estratégias ao mesmo tempo.

Goffman (1987, p.59ss.) descreve diversas estratégias de adaptação do indivíduo às condições ambientais da instituição total: 
afastamento da realidade, no qual o internado se abstém mediante graus variados de não participação em acontecimentos e interações; intransigência, em que o internado desafia intencionalmente o estabelecimento, ao negar-se de modo visível a cooperar com a equipe dirigente (a rebeldia costuma ser uma forma de reação inicial e temporária, depois o internado se utiliza de outras táticas adaptativas); colonização, onde o indivíduo se adapta de tal modo ao estabelecimento, que nele acaba por encontrar um lar, acreditando e sentindo que vive no melhor dos mundos e nunca teve nada melhor antes, usufruindo o máximo possível do que lhe propicia a vida institucional; conversão, na qual o internado parece aceitar a interpretação oficial da equipe dirigente e procura representar o papel do internado perfeito (o convertido aceita uma tática disciplinada, moralista e monocromática, apresentando-se como alguém cujo entusiasmo pelo estabelecimento está sempre à disposição da equipe dirigente); "se virar": quando as táticas anteriores representam comportamentos coerentes que podem ser seguidos, mas os internados não perseveram nelas por muito tempo. Eles acabam "se virando" e utilizam um "jogo de cintura”, ou seja, uma combinação oportunista de ajustamentos secundários, conversão, colonização e lealdade aos colegas, de modo a obter, dentro da situação específica, uma possibilidade máxima de evitar sofrimentos físicos ou psicológicos.

Um incidente na piscina onde os alunos internados tomavam banho (Pompéia, 1997, p.59) conduziu Sérgio a uma de suas estratégias adaptativas. Um internado maior que Sérgio arrasta-o para a parte funda da piscina, sem ser visto, criando um pretexto para salvar o garoto e se aproximar dele, numa estratégia nitidamente perversa, com a qual infunde medo e pavor e depois se oferece como salvador. $\mathrm{O}$ estratagema funcionou e Sérgio ficou amigo íntimo de Sanches, que o salvara.

A partir dessa fase introdutória de "aclimatação", como diz o próprio autor, podemos observar o desenrolar da "carreira moral" do menino Sérgio: depois de um esforço inicial para ser bom estudante, ele passa por uma experiência de sedução, cai na vadiagem e, por fim, é publicamente humilhado pelo diretor por suas más 
notas. "Já me era lícito julgar iniciado na convivência íntima da escola... estava aclimado, mas eu me aclimara pelo desalento, como um encarcerado no seu cárcere" (ibidem, p.62). Sérgio se sentiu desanimado, privado dos seus ideais ingênuos e acovardado. Esquece-se do alerta de Rebelo e desejou um protetor que o ajudasse naquele meio hostil. Sérgio se deixou namorar pelo vigilante, buscando proteção e um auxílio nos estudos.

[...] Pouco a pouco me ia invadindo a efeminação mórbida das escolas... sentia-me possuído de uma certa necessidade preguiçosa de amparo, volúpia de fraqueza em rigor impróprio do caráter masculino. Convencido de que a campanha do estudo e da energia moral não era precisamente uma cavalgada cotidiana, animada pelo clarim da retórica, como nas festas, e pelo verso enfático dos hinos, entristeceu-me a realidade crua. Desiludi-me dos bastidores da gloriosa parada, vendo-a pelo avesso. Nem todos os dias do militarismo enfeitam-se com a animação dos assaltos e das voltas triunfais; desmoralizava-me o ranram estagnado da paz das casernas, o prosaísmo elementar da faxina. (ibidem, p.63)

A situação psicológica de Sérgio era de desamparo, medo e receio, diante da agressiva realidade do Ateneu. "O braço de Sanches vinha assim salvar-me, segunda vez, de submersão, acudindo na vertigem do momento" (ibidem, p.63). "Descrente da fraternidade do colégio, cuja personificação representava-me o Barbalho, eu temia o alvoroço do recreio. Conservar-me na sala das lições era uma medida de prudência" (ibidem, p.67).

Sanches se tornou o protetor de Sérgio e o ajudou com os estudos, mas suas intenções sexuais a respeito do menino foram num crescendo dos gestos e proximidade física (ibidem, p.68). Sérgio "deixava tudo, fingindo-me insensível” (ibidem, p.68). Queria romper com o outro, mas não tinha coragem. Sérgio não via mal no comportamento do outro e, embora não gostasse daquela proximidade viscosa, não se manifestava com clareza. O outro, diante desse silêncio tácito, deveria se sentir mais estimulado. 
Às vezes a minha resistência passiva desapontava o preceptor. Ele encarava-me terrível, e como quem diz: "perde a proteção de um vigilante!", ou disfarçava a impertinência em riso amarelo, numa abstrata expressão de fisionomia, que era aliás o facies de uma ideia fixa. (ibidem, p.69)

Até que Sanches lhe fez uma proposta aberta, balbuciando-lhe uma pergunta. Sérgio decepcionou o pretendente por sua inocência e o vigilante se afastou, frio. Diante da ingenuidade do menino, Sanches se dedicou a prestar-lhe, sem ser solicitado, esclarecimentos sobre "as coisas da vida" para as quais o seu protegido era inocente. Era mais uma estratégia sedutora, como quem prepara o terreno e semeia, para uma futura colheita.

Eu me sentia amesquinhado sob o peso das revelações. Causava terror aquela sabedoria de coisas nunca sonhadas. O honrado diretor espiritual percebeu que havia agora um ascendente de domínio que me curvava. (Sanches) olhava-me então de frente e tinha ousados risos de malícia. Depois de dias de reserva, chegou-se de novo com uma segurança de possuidor forte. (ibidem, p.71)

Estavam sempre juntos, Sanches e Sérgio, com o pretexto de estudar. Sanches passeava com o menino por lugares pouco iluminados, abraçando-o e tocando-o nervosamente. Sérgio suportava o comportamento do outro, num deplorável estado de energia. "Eu aturava, imaginando em resignado silêncio o sexo artificial da fraqueza, que definira Rebelo" (ibidem, p.71). O outro, estimulado pela aparente entrega e assentimento tácito do pupilo, voltou à carga e fez-lhe nova proposta. Sérgio reagiu com asco e evadiu-se, rompendo com seu protetor, perdendo o amigo, o explicador e o vigilante.

Sanches, auxiliar responsável por supervisionar a turma de Sérgio, membro da equipe de vigilantes nomeados por Aristarco, retalia ao ser rechaçado, perseguindo o menino, que fracassou num exame e foi desmoralizado com repreensão solene, para grande regozijo do 
despeitado pretendente (ibidem, p.72). Sérgio decidiu então vadiar, chegando a ponto de ficar excluído de qualquer qualificação decente, até tornar-se o último da classe. A vadiagem de Sérgio pode ser entendida como uma estratégia de rebeldia passiva em um novo estilo de adaptação. "Fui o último da aula! Resultado razoável, para emprego de uma energiazinha que despontava” (ibidem, p.72).

O menino ficou solitário e calado, não ousando se aproximar de nenhum outro colega depois da experiência com Sanches. Este,

[...] rancoroso, perseguia-me como um demônio. Dizia coisas imundas. "Deixa estar, jurava entre dentes, que ainda hei de tirar-te a vergonha". Na qualidade de vigilante, levava-me brutalmente à espada. Eu tinha as pernas roxas de golpes; as canelas me incharam. (ibidem, p.77)

Sérgio fazia alguns esforços para reerguer-se e ninguém percebia, diante do que o menino foi se resignando, insensível, no seu desmoronamento. Passou então, a alimentar a fantasia de martírio: seu sofrimento o tornaria um santo (ibidem, p.74). Reagindo à tentativa de aliciamento pelo vigilante Sanches, desiludido dos ideais de trabalho e fraternidade que esperava encontrar no colégio, Sérgio mergulha numa fase religiosa e mística: "Perdido o ideal cenográfico de trabalho e fraternidade, que eu quisera que fosse a escola, tinha que soltar para outras bandas os pombos da imaginação. Viveiro seguro era o céu. Ficava-me a vendagem da eterna felicidade, que não se contava" (ibidem, p.74).

Sérgio era devoto de Santa Rosália (ibidem, p.78) e desfrutava dos momentos de oração e cânticos religiosos que os alunos eram obrigados a entoar no colégio, sobretudo no mês de maio (ibidem, p.80-2), que era dedicado à Virgem Maria. Mas o menino não admitia confissão, nem a comunhão, estranhava o exagero do culto público e tinha antipatia pelos "homens de batina". Seu misticismo era um sentimento privado. Uma forma de racionalizar, justificar e elaborar os sofrimentos aos quais estava exposto no ambiente do colégio interno. 
Todos os dias, no café da manhã, o diretor do Ateneu comentava em voz alta o desempenho acadêmico de cada aluno. Quando Sérgio foi chamado por Aristarco, durante a leitura do livro de notas, devido ao seu fracasso nos exames, "a congregação justiceira dos colegas voltou-se para mim, contra mim. Os vizinhos de lugar à mesa se afastaram dos dois lados, para que eu melhor fosse visto" (ibidem, p.76). O menino tremia, mas na primeira vez, o diretor foi clemente. Vieram, porém, as reincidências.

[...] Aristarco não perdoou mais. Houve ainda terceira, quarta, por diante. Cada uma delas doía-me intensamente; contudo não me indignavam. Aquele sofrimento eu o desejava, na humildade devota da minha disposição atual. Chorava à noite, em segredo, no dormitório; mas colhia as lágrimas numa taça, como fazem os mártires das estampas bentas, e oferecia ao céu, em remissão dos meus pobres pecados, com as notas más boiando. (ibidem, p.77)

Um segundo momento nessa etapa religiosa de Sérgio foi bastante desagradável, centrado nos aspectos mais ameaçadores da doutrina cristã: "Iniciara-me Sanches no Mal: Barreto instrui-me na Punição. Abria a boca e mostrava uma caldeira do inferno; as palavras eram chamas; ao calor daquelas práticas, as culpas ardiam como sardinhas em frege" (ibidem, p.94). Sérgio começou a achar a religião "de insuportável melancolia. Morte certa, hora incerta, inferno para sempre, juízo rigoroso; nada mais negro!" (ibidem, p.95). Seu fervor religioso começou a declinar.

O período místico de Sérgio terminou depois de uma aventura, uma autêntica embrulhada na qual ele se meteu com Franco, de quem se tornara muito próximo. Este queria se vingar das muitas humilhações que sofria por parte de todos e decidiu espalhar cacos de vidro na piscina da "natação". O remorso e a culpa transtornaram Sérgio e ele acabou adormecendo na capela, rezando em angústia, incapaz de delatar o colega. Nada aconteceu de grave, felizmente (ibidem, p.86-92). Sérgio resolveu mudar de atitude e sair do marasmo em que se afundava, abandonando o período de 
vadiação profunda e amolecimento hipnótico nos quais o mergulhou a atmosfera do Ateneu, suavizada apenas pela sua devoção religiosa. Quis se fazer independente. Pensamos que Sérgio se utilizou inicialmente da tática do afastamento da situação, como um modo de adaptação, depois do choque inicial. Ele se deixou levar pela corrente. Num segundo momento, resolveu reagir e passou a adotar uma postura mais intransigente e rebelde, mudando de estratégia. Sérgio passou para uma rebeldia ativa e solitária. Sérgio se deu conta de que chegou ao fundo do poço, ficou perplexo e buscou um modelo entre os colegas, com o qual se pudesse identificar.

O triunfo da escola poderia ser o Sanches; em compensação, humildade vencida era o Franco. Entre os dois extremos repugnantes, revelavam-se três amostras típicas à linha do bem-viver: Rebelo, um ancião; Ribas, um angélico; Mata, o corcunda, um polícia secreta. Para angélico decididamente não tinha jeito, estava provado, nem omoplatas magras; para ancião, não tinha idade, nem óculos azuis, nem mau hálito; para ser o Mata, faltava-me justo o caráter e a corcova... Onde estava o dever?... (ibidem, p.92)

Quando foi visitar a família, Sérgio informou a seu pai tudo o que estava vivendo no colégio, relatou-lhe suas dificuldades, procurando obter ajuda para reagir. O menino obteve sucesso total em sua entrevista com o pai. Essa reação de Sérgio vem lembrar ao estabelecimento que ele deve considerar o status e relações sociais do internado no mundo externo: o estabelecimento deve respeitar alguns dos direitos do internado enquanto pessoa. Nesse caso, os parentes de Sérgio lembram à equipe dirigente suas obrigações quanto a padrões humanitários e direitos do indivíduo. O próprio estudante desempenha bem esse papel.

Dias depois, no colégio, eu era um pequeno potentado. Derrubei o Sanches; consegui revogação da disciplina das espadas; reconquistei a benevolência de Mânlio (o professor); levantei a cerviz! Desembaraçado do arbítrio pretensioso de um vigilante, o trabalho 
agradou-me. [...] Com uma palavra fez-se um anarquista. Daí por diante era fatal o conflito entre a independência e a autoridade. Aristarco tinha de roer. Em compensação, adeus esperanças de ser um dia vigilante! Adeus indolência feliz dos tempos beatos. (ibidem, p.98)

Sérgio estabeleceu para si um novo programa, pautado pela "razoável mediocridade sem compromissos", desprezando com vaidade prêmios, aplausos, não quis se tornar exemplar nem pagar o preço de se tornar um aluno modelo. Os superiores desenvolveram uma antipatia pelo menino e "invejosos da minha altivez, os inimigos fizeram partido. Sanches era o chefe, na cortina: Barbalho era o líder abertamente. Eu sorria vaidoso, levando de vencida a guerrinha, como a espuma à proa de um barco" (ibidem, p.99). Esse foi o caráter que Sérgio procurou manter, depois de algumas oscilações em sua carreira moral. Podemos dizer que ele assumiu uma estratégia de adaptação que consistia numa certa intransigência irônica e na "viração", procurando combinar de modo oportunista várias estratégias e "jogo de cintura” para evitar sofrimentos e usufruir o possível da vida no estabelecimento.

\section{A sexualidade no contexto institucional}

Na etapa seguinte de sua carreira moral, Sérgio assumiu gentilmente o papel de namorada platônica de Bento Alves e se deixou cortejar, necessitado da proteção de um companheiro forte no ambiente hostil do Ateneu.

Bento Alves era um misterioso. Mistérios são no colégio os que não andam a atravancar o espaço com as gatimanhas das suas expansões. Frequentava as aulas superiores; sem que fosse um estudante de rumoroso mérito, fazia-se respeitar dos mestres e condiscípulos. Sisudo como certos rapazes de inteligência menor que se arreceiam do ridículo, não somente pela sisudez impunha-se ao respeito. Consideravam-no principalmente pela nomeada de hercúleo. Os fortes constituem realmente uma fidalguia de privilégios 
no internato. No tumulto da existência em comum, fundem-se as distinções de classe na democracia do coleguismo; as cambiantes de fortuna apagam-se no figurino geral das blusas pardas. Os títulos de superioridade prevalecem primitivamente no critério semibárbaro dos verdes anos; o punho válido chega a fazer vantagem sobre a própria vantagem do favoritismo. (ibidem, p.108)

Alves não alardeava de forte; evitava disputas, não jogava o pulso, preferia exercitar-se à ginástica sem espectadores. Às vezes, por brinquedo, cingia o braço a um colega entre o polegar e o médio e fechava-lhe sob a manga um bracelete roxo dolorido. Aqueles que se sujeitavam ao formidável ensaio de tatuagem por compressão acercavam-se daí por diante de Bento Alves com os escrúpulos da mais reservada prudência (ibidem, p.108-9).

Entretanto era mole, da preguiça monumental dos animais pujantes. Veloz, detestava a carreira; alegre, fugia aos folguedos. Gostava do seu sossego; desviava os incômodos da convivência distribuída, transbordante dos estimados. Não se falava dele no Ateneu. Limitavam-se a temê-lo em silêncio. (ibidem, p.109)

A amizade de Bento Alves por mim, e a que nutri por ele, me faz pensar que, mesmo sem o caráter de abatimento que tanto indignava ao Rebelo, certa efeminação pode existir como um período de constituição moral. Estimei-o femininamente, porque era grande, forte, bravo; porque podia me valer; porque me respeitava, quase tímido, como se não tivesse ânimo de ser amigo. Para me fitar, esperava que eu tirasse dele os meus olhos. A primeira vez que me deu um presente, gracioso livro de educação, retirou-se corado, como quem foge. Aquela timidez, em vez de alertar, enternecia-me, a mim que, aliás, devia estar prevenido contra escaldos de água fria. Interessante é que vago elemento material havia nesta afeição de criança, tal qual se nota em amor, prazer no contato fortuito, de um aperto de mãos, da emanação da roupa, como se absorvêssemos um pouco do objeto simpático. (ibidem, p.116) 
Na biblioteca, Bento Alves escolhia-me as obras: imaginava as que me podiam interessar; e propunha a compra, ou as comprava e oferecia ao Grêmio, para dispensar-se de mas dar diretamente. No recreio não andávamos juntos; mas eu via de longe o amigo, atento, seguindo-me o seu olhar como um cão de guarda. Soube depois que ameaçava torcer o pescoço a quem pensasse apenas em me ofender; seu irmão adotivo! confirmava. Eu, que desde muito assumira entre os colegas um belo ar de impávida altania, modificava-me com o amigo, e me sentia bem na submissão voluntária, como se fosse artificial a bravura, a maneira da conhecida petulância feminina. (ibidem, p.117)

Bento Alves desenvolveu e manteve com Sérgio uma relação amorosa platônica e repleta de cuidados do mais velho com o mais jovem.

No movimento geral da existência do internato, desvelava-se caprichosamente; sabia ser, de modo inexprimível, fraternal, paternal, quase digo amante, tanta era a minudência dos seus cuidados. Não havia regalo, dessas mesquinhas coisas de preço enorme na carestia perpétua da prisão escolar, de que não se privasse o Alves, em meu proveito, desesperando-se, a fazer pena, se eu tentasse recusar. À conversa, falava da família no Rio Grande do Sul; tinha duas irmãs; falava delas, do tempo passado que não as via, muito claras, de belos olhos, uma de quinze anos, outra de doze; ele tinha dezoito. Falava de cuidados higiênicos meus, mudar de cama no salão azul, que estava muito perto das janelas e isto havia de ser nocivo... Outras ninharias, em tom de sentida brandura, como se desejasse decrescer das proporções sólidas de sua conformação para reduzir-se à exiguidade balbuciante de uma carcaçazinha de avó, minguada de velhice, animada ainda e apenas pela febre do último alento, pela necessidade de carregar ainda alguns dias um coração, um afeto. (ibidem, p.117-18)

O meu bom amigo, exagerado em mostrar-se melhor, sempre receoso de importunar-me com uma manifestação mais viva, 
inventava cada dia nova surpresa e agrado. Chegara ao excesso das flores. A princípio, pétalas de magnólia seca com uma data e uma assinatura, que eu encontrava entre folhas de compêndio. As pétalas começaram a aparecer mais frescas e mais vezes; vieram as flores completas. Um dia, abrindo pela manhã a estante numerada do salão do estudo, achei a imprudência de um ramalhete. Santa Rosália da minha parte nunca tivera um assim. Que devia fazer uma namorada? Acariciei as flores, muito agradecido, e escondi-as antes que vissem. (ibidem, p.131)

Os inimigos de Sérgio, Barbalho e seu grupo não estavam alheios ao que se passava. O romance secreto de Sérgio e Bento Alves certamente não passava desapercebido aos olhos dos colegas internados, sobretudo dos inimigos que não dormem. À aversão desse grupo a Sérgio, juntou-se a inveja ao Bento Alves, que se tornou herói no Ateneu ao render um dos empregados da casa que cometeu um assassinato (ibidem, p.102-3).

Mas o Barbalho espiava, ultimamente constituído fiscal oculto dos meus passos. As circunstâncias o tinham aproximado do Malheiro, e o açafroado caolho pretendia manejar a rivalidade dos dois maiores: um conflito entre Malheiro e Bento poderia ser a vergonha para mim. (ibidem, p.131)

Malheiro passou a perseguir Sérgio, infernizando-o com provocações e insinuações.

Queria incomodar o Alves, mortificando-me, julgando que me queixasse. Eu devorava as afrontas do marmanjo sem descobrir o meio de tirar correta desforra. Depois de incitar o Malheiro contra mim, incitou o Bento contra o Malheiro. Procurou-o misteriosamente e informou: "O Malheiro não passa pelo Sérgio sem que pergunte quando é o casamento... é preciso casar... Ainda hoje pediu convite para as bodas. O Sérgio está desesperado”. O furor 
do Alves não se descreve, furor poderoso dos calados. Uma onda de apoplexia ruborizou-lhe as faces. Por um único movimento de indignação contraiu os dedos, como se estrangulando. Procurou o Malheiro e com a voz talvez alterada, mas sem ódio, fez intimação: "Amanhã é a sessão de encerramento; em meio da festa saímos ambos; preciso falar-lhe das bodas." Malheiro percebeu: era o sonhado encontro! (ibidem, p.131-2)

No momento marcado, quando ambos saíram do auditório, Sérgio adivinhou o que acontecia. Terminadas as atividades acadêmicas, Sérgio saiu para o pátio e recebeu uma carta do Alves: "Estou preso; antes que te digam que por alguma indignidade, previno: por ter dado uma lição ao Malheiro" (ibidem, p.132).

Enquanto Alves e Malheiro lutavam, Barbalho foi denunciá-los ao diretor e no fim da luta, Bento Alves foi surpreendido com uma ordem de prisão do diretor. Os dois contendores recusaram-se a dar explicações. "Não denunciar nunca é preceito sagrado de lealdade no colégio" (ibidem, p.132). Malheiro apanhou bastante.

Sérgio foi ver o amigo na prisão.

Por minha parte, entreguei-me de coração ao desespero das damas romanceiras, montando guarda de suspiros à janela gradeada de um cárcere onde se deixava deter o gentil cavalheiro, para o fim único de propor assunto às trovas e aos trovadores medievos. (ibidem, p.132)

O tempo passou no internato. "Bento Alves, depois de assegurar que unicamente por mim se havia sujeitado à humilhação que sofrera, andava propositalmente arredio" (ibidem, p.139). Mais tarde, os dois amigos voltaram ao antigo relacionamento.

As simpatias do excelente companheiro não tinham diminuído. Durante as férias, fora ver-me em casa, travando relações com a minha família. Fui recomendado insistentemente ao amigo, que 
me valesse, nas dificuldades da vida colegial, contra o constante perigo da camaradagem perniciosa. Durante o mês de janeiro não nos vimos. Por ocasião da abertura das aulas, notei-lhe um calor novo na amizade, sem efusões como dantes, mas evidentemente testemunhado por tremores da mão ao apertar a minha, embaraços na voz de amoroso errado, bisonho desviar dos olhos, denunciando a relutância de movimentos secretos e impetuosos. Às vezes mesmo, um reflexo assustador de loucura acentuava-se-lhe nos traços. (ibidem, p.162)

Interessava-me aquela agonia comprimida. Estranha coisa, a amizade que, em vez da aproximação franca dos amigos, podia assim produzir a incerteza do mal-estar, uma situação prolongada de vexame, como se a convivência fosse um sacrifício e o sacrifício uma necessidade. (ibidem, p.162)

Durante os primeiros dias do ano, poucos alunos chegados, ficávamos horas inteiras em companhia. Trouxera-me um presente de livros, com dedicatória a cores, de bela caligrafia, inscritas em rosas entrelaçadas de cromo. Recordo-me também de um dulcíssimo cofre dourado de pastilhas e outras ridicularias de amabilidade que me oferecia, passado de vergonha pela insignificância do obséquio. Confusamente, ocorria-me a lembrança do meu papelzinho de namorada faz-de-conta, e eu levava a seriedade cênica a ponto de galanteá-lo, ocupando-me com o laço de gravata dele, com mecha de cabelos que lhe fazia cócegas aos olhos; soprava-lhe ao ouvido segredos indistintos para vê-lo rir, desesperado de não perceber. Uma das irmãs casara no Rio Grande; ele mostrou-me o retrato do noivo, um par de bigodes negros descaídos, com a noiva, um rosto oval correto e puro, o turbilhão nevoento dos véus. Deu-me um botão de flor de laranjeira que tinham remetido. (ibidem, p.162)

As coisas corriam assim, serenas, quando, não mais que de repente, houve uma mudança radical. Bento Alves inexplicavelmente atacou Sérgio e lutou com ele, num desvairamento completo. 
Espancado pelo amigo irreconhecível e forte, Sérgio defendeu-se como pôde, atacando-o com um sapato velho (ibidem, p.163).

Aristarco surpreendeu a briga e Bento Alves retirou-se. O diretor exigiu explicações de Sérgio que lhe respondeu com violência. Aristarco enfureceu-se e suspendeu o rapaz pela roupa ameaçando- o e exigindo explicações. Sérgio agarrou-lhe os bigodes, aturdido, esperneando, contorcendo-se, sem observar as "conveniências do respeito”. Aristarco soltou o rapaz, escandalizado, sentindo-se ultrajado por ter sido agarrado pelos bigodes: "Criança! Feriste um velho!... Ah! Meu filho, ferir a um mestre é como ferir ao próprio pai e os parricidas serão malditos" (ibidem, p.163-4).

O tom comovido deste final inesperado impressionou-me até o íntimo da alma. Estava vencido. Fiquei por um minuto horrorizado de mim mesmo. De volta do atordoamento, achei-me só no corredor. A saída dramática do diretor aumentou-me ainda os remorsos. Houve uma reação de esforço moral e desatei nervosamente em pranto, chorei a valer, amparando-me ao peitoril de uma janela. Contava certo com um castigo excepcional, uma cominação qualquer do célebre código do arbítrio, em artigo cujo grau mínimo fosse a expulsão solene. (ibidem, p.164)

Sérgio esperou alguns dias pelo castigo que não veio.

[...] Bento Alves despedira-se do Ateneu na mesma tarde do extraordinário desvario. Acreditei algum tempo que a minha impunidade era um caso especial do afamado sistema das punições morais e que Aristarco delegara ao abutre da minha consciência o encargo da sua justiça e desafronta. (ibidem, p.164)

Depois, Sérgio concluiu que não compensava para o diretor perder duas mensalidades de uma só vez, além do que o incidente, embora desagradável, não teve testemunhas. "O caso morreu em segredo de discrição, encontrando-nos eu e o diretor num conchavo bilateral de reserva, como se nada houvesse" (ibidem, p.164). 


\section{Sérgio no secundário}

Ao passar para o secundário, Sérgio faz um balanço do seu tempo e experiência de internação no colégio, refletindo sobre sua ingenuidade infantil inicial e todas as suas decepções posteriores. O colégio passa definitivamente a representar um cárcere para o adolescente. Agora ele já era um veterano no Ateneu e conhece bem os meandros da vida no estabelecimento escolar. Inicia-se uma nova etapa em sua carreira moral. O tempo da novidade foi seguido pelo da desilusão e do sofrimento. À continuação, veio a resignação cética.

Depois dos exames primários (ibidem, p.146-8), enquanto esperava com os colegas a leitura da lista dos aprovados, Sérgio contempla os quadros de alto relevo nos quais, representando as artes e indústrias, meninos nus feitos de gesso dançam em roda fraternal. Sérgio refletiu.

Senti-me velho. Que longa viagem de desenganos! Alguns meses apenas, desde que vira, à primeira vez, as ideais crianças vivificadas no estuque pelo contágio do entusiasmo ingênuo, ronda feliz do trabalho... Agora, um por um que os interpretasse, aos pequenos hipócritas mostrando as nádegas brancas com um reverso igual de candura, um por um que os julgasse, e todo aquele gesso das facezinhas rechonchudas coraria de uma sanção geral e esfoladora de palmadas. Não me enganavam mais os pequeninos patifes. Eram infantis, alegres, francos, bons, imaculados, saudáveis dos primeiros anos, tempos da escola que não voltam mais!... E mentiam todos!... Cada rosto amável daquela infância era a máscara de uma falsidade, o prospecto de uma traição. Vestia-se ali de pureza a malícia corruptora, a ambição grosseira, a intriga, a bajulação, a covardia, a inveja, a sensualidade brejeira das criaturas eróticas, a desconfiança selvagem da incapacidade, a emulação deprimida do despeito, a impotência, o colégio, barbaria de humanidade incipiente, sob o fetichismo do Mestre, confederação de instintos em evidência, paixões, fraquezas, vergonhas que a sociedade exagera e 
complica em proporção de escala, respeitando o tipo embrionário, caracterizando a hora presente, tão desagradável para nós, que só vemos azul o passado, porque é ilusão e distância. (ibidem, p.148)

No ano seguinte, o Ateneu revelou-se noutro aspecto. Conhecera-o interessante, com as seduções do que é novo, com as projeções obscuras de perspectiva, desafiando curiosidade e receio; conhecera-o sípido e banal como os mistérios resolvidos, caiados de tédio; conhecia-o agora intolerável como um cárcere, murado de desejos e privações. (ibidem, p.151)

Depois das férias, quando esteve em contato com a vida social corrente, aumenta sua consciência dos limites da vida no internato escolar.

Comecei a penetrar a realidade exterior como palpava a verdade da existência no colégio. Desesperava-me então ver-me duplamente algemado à contingência de ser irremissivelmente pequeno e ainda colegial. Colegial, quase calceta! marcado com um número, escravo dos limites da casa e do despotismo da administração. (ibidem, p.152)

Sérgio inicia uma nova amizade na sua fase de colegial. Egbert é seu novo amigo. "Adquirira-o com a transição para as aulas secundárias, onde o encontrei com outros adiantados. Vizinhos de banco, compreendemo-nos, mutuamente simpáticos, como se um propósito secreto de coisa necessária tivesse guiado o acaso da colocação" (ibidem, p.169).

Conheci pela primeira vez a amizade. A insignificância cotidiana da vida escolar, em que a gente se aborrece, é favorável ao desenvolvimento de inclinações mais sérias que as de simples conveniência menineira. $\mathrm{O}$ aborrecimento é um feitio da ociosidade, e da mãe proverbial dos vícios gera-se também o vício de sentir. (ibidem, p.169) 
A convivência do Sanches fora apenas como o afeiçoamento aglutinante de um sinapismo, intolerável e colado, espécie de escravidão preguiçosa da inexperiência e temor; a amizade de Bento Alves fora verdadeira, mas do meu lado havia apenas gratidão, preito à força, comodidade da sujeição voluntária, vaidade feminina de dominar pela fraqueza, todos os elementos de uma forma passiva de afeto, em que o dispêndio de energia é nulo, e o sentimento vive de descanso e de sono. Do Egbert, fui amigo. Sem mais razões, que a simpatia não se argumenta. Fazíamos os temas de colaboração; permutávamos significados, ninguém ficava a dever. Entretanto, eu experimentava a necessidade deleitosa da dedicação. Achava-me forte para querer bem e mostrar. Queimava-me o ardor inexplicável do desinteresse. Egbert merecia-me ternuras de irmão mais velho. (ibidem, p.169-70)

Tinha o rosto irregular, parecia-me formoso. De origem inglesa, tinha os cabelos castanhos entremeados de louro, uma alteração exótica na pronúncia, olhos azuis de estrias cinzentas, oblíquos, pálpebras negligentes, quase a fechar, que se rasgavam, entretanto, a momentos de conversa, em desenho gracioso e largo. (ibidem, p.170)

Vizinhos de dormitório, eu, deitado, esperava que ele dormisse para vê-lo dormir e acordava mais cedo para vê-lo acordar. Tudo que nos pertencia, era comum. Eu por mim positivamente adorava-o e o julgava perfeito. Era elegante, destro, trabalhador, generoso. Eu admirava-o, desde o coração até a cor da pele e à correção das formas. Nadava como as toninhas. A água azul fugia-lhe diante em marulho, ou subia-lhe aos ombros, banhando de lustre de marfim polido a brancura do corpo. Dizia as lições com calma, dificilmente às vezes, embarcado por aspirações ansiosas de asfixia. Eu mais o prezava nos acessos doentios da angústia. Sonhava que ele tinha morrido, que deixara bruscamente o Ateneu; o sonho despertava-me em susto, e eu, com alívio, avistava-o tranquilo, na cama próxima, uma das mãos sob a face, compassando a respiração ciciante. No recreio, éramos inseparáveis, complementares como duas condições recíprocas 
de existência. Eu lamentava que uma ocorrência terrível não viesse de qualquer modo ameaçar o amigo, para fazer valer a coragem do sacrifício, trocar-me por ele no perigo. Vinham-me reminiscências dos exemplos históricos de amizade; a comparação pagava bem. (ibidem, p.170)

No campo dos exercícios, à tarde, passeávamos juntos, voltas sem fim, em palestra sem assunto, por frases soltas, estações de borboletas sobre as doçuras de um bem-estar mútuo, inexprimível. Falávamos baixo, bondosamente, como temendo espantar com a entonação mais alta, mais áspera, o favor de um gênio benigno que estendia sobre nós a amplidão invisível das asas. Amor unus erat. (ibidem, p.170-1)

Entrávamos pelo gramal. Como ia longe o burburinho de alegria vulgar dos companheiros! Nós dois sós! Sentávamos à relva. Eu descansando a cabeça aos joelhos dele, ou ele nos meus. Calados, arrancávamos espiguilhas à grama. O prato era imenso, os extremos escapavam já na primeira solução de crepúsculo. Olhávamos para cima, para o céu. Que céu. Que céus de transparência e de luz! Ao alto, ao alto, demorava-se ainda, em cauda de ouro, uma lembrança do sol. A cúpula funda descortinava-se para as montanhas, diluição vasta, tenuíssima de arco-íris. Brandos reflexos de chama, depois, o belo azul de pano, depois a degeneração dos matizes para a melancolia noturna, prenunciada pela última zona de roxo doloroso. Quem nos dera ser aquelas aves, duas, que avistávamos na altura, amigas, declinando feliz a luz, em pleno dia ainda, quando na terra iam por tudo as sombras! (ibidem, p.171)

Os dois amigos liam muito em companhia, a solidão de Robinson Crusoé, a solidão e o sentimento de Paulo e Virgínia, enlevavam-se com a pastoral de Bernardin de Saint- Pierre, esboçavam poesias e romances ambientados na Idade Média.

Quando Sérgio ouviu o nome do amigo citado no "processo do caso Cândida", investigação institucional de uma ocorrência de 
homossexualidade entre os alunos (ibidem, p.160ss.), sofreu em silêncio o golpe e desesperou-se por não encontrar um meio de partilhar com Egbert a vergonha. Quando tudo passou e Egbert não sofreu maiores sanções, Sérgio reencontrou-o e não comentaram nem uma vez sequer o desagradável incidente, manifestando assim a solidariedade entre os internados (ibidem, p.173). Declamavam juntos o teatro clássico.

Um era Augusto, outro Cina; um Nearco, outro Poliúto; um Horácio, outro Curiácio, D. Diogo e o Cid, Joas e Joad, Nero e Burro, Filinto e Alceste, Tartufo e Cleanto. O arvoredo era um cenário deveras. Dialogávamos, com toda a força das encarnações dramáticas, a gravura cavalheiresca, o civismo romano, as apreensões de rei ameaçado, o heroísmo da fé, os arrufos da misantropia, as sinuosidades do hipócrita. Uma estátua de deusa anônima, de louça esfolada, verde de velhice, constituía o auditório, auditório atento fixamente, comedido, sem demasias de aplausos nem reprovação, mas constante e infatigável. (ibidem, p.175)

Para o desempenho de papéis femininos havia dificuldades; cada um queria a parte mais enérgica do recitativo. Tirava-se a sorte, e, segundo o acaso, um de nós ou o outro enfiava sem cerimônia as saias de qualquer dama e ia perfeita a toilette do sentimento; noivado de Chimène, desespero de Camila, luto de Paulina, ambição de Agripina, soberania de Ester, astúcia de Elmira, dubiedade de Celimene. Outro papel custoso de distribuir era o de Burro, papel honesto, entretanto, e altamente simpático. Ninguém o queria fazer, o virtuoso conselheiro de Nero. (ibidem, p.175)

Nesse idílio ia a amizade de Sérgio e Egbert, até que ambos foram premiados com um jantar na casa do diretor, por terem se distinguido nos estudos. No jantar, Sérgio fica deslumbrado com Ema, a esposa de Aristarco.

Uma atenção absorveu-me exclusiva e única. D. Ema reconheceu-me: era aquele pequeno das madeixas compridas! Conversou 
muito comigo. Um fiapo branco pousava-me ao ombro do uniforme; a boa senhora tomou-o finamente entre os dedos, soltou-o e mostrou-me, sorrindo, o fio levíssimo a cair lentamente no ar calmo... Estava desenvolvido! Que diferença do que era há dois anos!... Miragem sedutora de branco, fartos cabelos negros colhidos para o alto com infinita graça, uma rosa nos cabelos, vermelha como são vermelhos os lábios e os corações, vermelha como um grito de triunfo. Nada mais. Ramalhetes à mesa, um caldo ardente, e sempre a obsessão adorável do branco e a rosa vermelha. Estava a meu lado, pertinho, deslumbrante, o vestuário de neve. Servia-me alguns pratos, muitas carícias; eu devorava as carícias. Não ousava erguer a vista. Uma vez ensaiei. Havia sobre mim dois olhos perturbadores, vertendo a noite... (ibidem, p.176)

Quando retornou ao Ateneu, Sérgio encontrava-se transformado: "De volta ao Ateneu, senti-me grande. Crescia-me o peito indefinivelmente, como se me estivesse a fazer homem por dilatação" (ibidem, p.176-7). A paixão por Ema modificou seu relacionamento com Egbert: "[...] olhava agora para Egbert como para uma recordação e para o dia de ontem. Daí começou a esfriar o entusiasmo de nossa fraternidade" (ibidem, p.177). Sérgio sonhava com sua amada (ibidem, p.181).

Que outra criatura era eu ao despertar! A aparição encantadora extinta; mas eu sofria da reação das trevas que sucede aos deslumbramentos. Continuava cordialmente com o Egbert. Parecia-me, entretanto, a sua amizade agora uma coisa insuficiente como se houvesse em mim uma selvageria amordaçada de afetos. Egbert parecia às vezes um intruso. Passeando com ele, que diferença de outrora! Produzia-me o efeito de uma terceira pessoa. Eu preferia andar só. (ibidem, p.181-2)

Sérgio foi submetido a novos exames escolares e promovido (ibidem, p.177-81). Também foi transferido para o dormitório dos maiores. "Esta mudança distanciava-me ainda mais do Egbert; 
passamos a nos encontrar somente à tarde, no campo" (ibidem, p.182).

Nessa nova fase, Sérgio pouco se ocupava dos estudos e passava o tempo deitado preguiçosamente, manifestando aí sua estratégia adaptativa e ajustamento secundário: "Depois das aulas, subia para o dormitório, aproveitando-me do relaxamento da polícia do salão. O inspetor responsável era o Silvino. Receoso de uma represália dos grandes, o prudente bedel deixava andar" (ibidem, p.182). Com os internados maiores, a vigilância era obrigada a fazer concessões, medindo forças e usando de maior prudência, para evitar uma agressão que revidasse uma repressão exagerada.

Eu deitava-me preguiçoso, ouvindo a grita do pátio, como coisa absolutamente alheia à minha vida. Contava as tábuas do teto, porção de traços paralelos que se perdiam num reflexo de tinta. Às vezes lia narrativas de Dumas, que não distraíam. Em outras camas, deitados como eu, de cara para cima, cruzando os botins, alguns colegas fumavam, soprando, devagarinho, colunas de fumo que subiam, verticalmente, e rodavam azuis. A um canto, no fim do salão, jogavam três parceiros, bocejantes, acentuando sem entusiasmo as alternativas do azar como uma partida de sonâmbulos. Muitas vezes na modorra pesada da sesta, as costas aquecidas da posição, fechando-me os olhos, ao brilho do sol que adivinhava lá fora no terreiro abrasado, eu adormecia. À hora da aula ou do jantar, um companheiro puxava-me. (ibidem, p.182)

Estes intervalos de dormência sem sonho, sem ideias, sem definida cisma, eram o meu sossego. Pensar era impacientar-me. Que desejava eu? Sempre o desespero da reclusão colegial e da idade. Vinham-me crises nervosas de movimento, e eu cruzava de passos frenéticos o pátio, sôfrego, acelerando-me cada vez mais, como se quisesse passar adiante do tempo. Nem me interessavam as intrigas do salão. E que intrigas! Exatamente a substância do afamado mistério do chalé, dormitório coletivo dos maiores, objeto de ambição curiosa dos menores do internato. (ibidem, p.182) 
Podemos observar uma espécie de moratória à qual o adolescente internado num colégio está submetido: seu aborrecimento, tédio, falta de sentido, desejo de que o tempo passe depressa e que ele cresça, para finalmente ser livre, adulto, capaz de exercer-se na vida.

\section{Epílogo: a emergência do feminino na vida de Sérgio}

Depois da "solenidade da distribuição bienal dos prêmios" (ibidem, p.193-204), Sérgio caiu doente: "Logo depois da festa de educação física, que foi alguns dias depois da grande solenidade dos prêmios, eu adoecera. Sarampos, sem mais nem menos. Por motivo dos seus padecimentos, meu pai seguira para a Europa, levando a família. Eu ficara no Ateneu, confiado ao diretor, como a um correspondente" (ibidem, p.207).

Meia dúzia de rapazes eram meus companheiros. Que terrível soledade o Ateneu deserto. No pátio, o silêncio dormia ao sol, como um lagarto. Vagávamos, bocejando pelas salas desmontadas, despidas; as carteiras amontoadas num canto, na caliça os pregos somente das cartas com alguns quadros restantes de máximas, por maior insipidez, os mais teimosos conselhos morais. Nos dormitórios, as camas desfeitas mostravam o esqueleto de ferro pintado, o xadrez das chapas cruzadas. Principiava um serviço vasto de lavagem, envernizagem, caiação; vieram pintores reformar os aspectos do edifício que se renovavam todos os anos. Os tristes reclusos das férias, ficávamos, no meio daquela restauração geral, como coisas antigas, do outro ano, como o deplorável inconveniente de se não poder caiar de novo e pintar. (ibidem, p.207-8)

Sérgio sentiu-se fisicamente mal.

Assim passei alguns dias sem me queixar. Certa manhã, descubro no corpo um formigamento de pintinhas rubras. Aristarco fez-me recolher na enfermaria, um prolongamento de sua residência para os lados da natação. Veio o médico, o mesmo do Franco; não 
me matou. D. Ema foi para mim o verdadeiro socorro. Sabia tanto zelar, animar, acariciar, que a própria agonia aos cuidados do seu trato fora uma ressurreição. (ibidem, p.208)

Sérgio ficou recluso na enfermaria enquanto se recuperava da doença, sob os cuidados maternais de Ema e seu amor por ela floresceu com intensidade.

A convivência cotidiana na solidão do aposento estabelecera a entranhada familiaridade dos casais. Ema afetava não ter mais para mim avarezas de colchete. "Sérgio, meu filhinho." Dava-se os bons dias. Saía, voltava fresca, com o grande, vernal sorriso rorejado ainda do orvalho das ablusões. Rindo sem causa: da claridade feliz da manhã, de me ver forte, quase bom. Debruçava-se expansiva, resplendendo a formosura sobre mim, na gola do peignoir, como um derramamento de flores de uma cornucópia. Tomava-se a fronte nas mãos, colava à dela; arredava-se um pouco e olhava-me de perto, bem dentro dos olhos, num encontro inebriante de olhares. Aproximava o rosto e contava, lábios sobre lábios, mimosas historietas sem texto, em que falava mais a vivacidade sanguínea da boca, do que a imperceptível confusão dos arrulhos cantando-se na garganta como um colar sonoro. Achava-me pequenino, pequenino. Sentava-se à cadeira. Tomava-me ao colo, acalentava-me, agitava-me contra o seio como um recém-nascido, inundando-me de irradiações quentes de maternidade, de amor. Desprendia os cabelos e com um ligeiro movimento de espáduas fazia cair sobre mim uma tenda escura. De cima, sobre as faces, chegava-me o bafejo tépido da respiração. Eu via, ao fundo da tenda, incerto como em sonhos, a fulguração sideral de dois olhos. (ibidem, p.212)

Sérgio convalesceu nesse romance platônico com sua enfermeira. Mas "tudo acabou com um fim brusco de mau romance" (ibidem, p.213). O Ateneu ardeu em chamas e foi consumido num incêndio. $\mathrm{O}$ autor do sinistro foi Américo, um aluno internado no Ateneu à própria revelia pelo pai. 
Entre os reclusos das férias, contava-se um rapaz, matriculado de pouco, o Américo. Vinha da roça. Mostrou-se contrariado desde o primeiro dia. Aristarco tentou abrandá-lo; impossível: cada vez mais enfezado. Não falava a ninguém. Era crescido e parecia de robustez não comum. Olhavam para ele como para uma fera respeitável. De repente desapareceu. Passado algum tempo vieram três pessoas reconduzindo-o: o pai, um correspondente e um criado. O rapaz amarelo, com manchas vermelhas, movediças, no rosto, mordia os beiços até ferir. O pai pediu contra ele toda a severidade. Aristarco, que tinha veleidades de amansador, gloriando-se de saber combinar irresistivelmente a energia com o modo amoroso, tranquilizou o fazendeiro: "Tenho visto piores". Carregando a vista com toda a intensidade da força moral, segurou o discípulo rijamente pelo braço e fê-lo sentar-se. "Tu ficarás, meu filho!" O moço limitou-se a responder, cabisbaixo, possuído de repentina complacência: "Eu fico". Dizem que o pai o tratara terrivelmente, vendo-o apresentar-se em casa, evadido. Com a proximidade da festa dos prêmios o caso do desertor ficou esquecido, e ninguém jamais foi como ele exemplo de cordura. (ibidem, p.213)

O fogo devorou o colégio. "O incêndio fora propositalmente lançado pelo Américo, que para isso rompera o encanamento do gás no saguão das bacias. Desaparecera depois do atentado" (ibidem, p.217). Impossível não ver no gesto do incendiário uma semelhança com o que acontece atualmente nas revoltas em presídios e instituições de internamento para adolescentes infratores, que incendeiam colchões e pavilhões inteiros, rebelando-se contra condições desumanas de vida.

Por outro lado, esse desfecho trágico da história também nos faz pensar na vingança de Pompéia contra sua longa e árdua experiência no colégio interno: ao escrever suas memórias, pôde acertar as contas com o passado, e tal como os internos de hoje aos quais aludimos acima, ateou fogo ao Ateneu, revoltado com sua condição de adolescente internado. 
"Desaparecera igualmente durante o incêndio a senhora do diretor" (ibidem, p.217). Golpe de misericórdia infligido no poderoso Aristarco? "Lá estava Aristarco, tresnoitado, o infeliz... Lá estava, a uma cadeira em que passara a noite, imóvel, absorto, sujo de cinza como um penitente, o pé direito sobre um monte de carvões, o cotovelo espetado na perna, a grande mão felpuda envolvendo o queixo, os dedos perdidos no bigode branco, sobrolho carregado" (ibidem, p.217). "Ele, como um deus caipora, triste, sobre o desastre universal de sua obra” (ibidem, p.218). Aqui Pompéia/Sérgio interrompe sua "crônica das saudades" (ibidem, p.218).

Em seu percurso pelo internato escolar, Sérgio foi confrontando a vida mesma em sua multiplicidade: amores, ódios, rixas, rivalidades, orgulho, vaidade, posições femininas, masculinas, o menino tornou-se um homem. O menino pôde sair do Ateneu, mas parece que foi difícil o Ateneu sair do menino. Talvez Raul Pompéia tenha produzido $O$ Ateneu para apropriar-se de sua dolorosa formação escolar e existencial. Inclusive podemos também pensar num forte processo de institucionalização, pois, de acordo com Goffman (1987), a internação prolongada produz uma maior resistência a deixar o estabelecimento de reclusão. Ter vivido tal experiência constitui um sujeito, sua história faz dele o que é hoje. Pompéia parece orbitar o internato onde viveu como seu "grande sintoma". É semelhante ao ex-usuário de drogas que, inclusive, em abstinência voluntária, permanece orbitando-a, mesmo que seja trabalhando em uma clínica que se ocupa com usuários. De qualquer modo, o objeto permanece central na sua vida.

\section{O internato escolar como um estabelecimento formativo, educativo e terapêutico}

O Ateneu pode ser considerado um estabelecimento pedagógico que possui aspectos de um sistema correcional, exercendo as funções de reclusão e de custódia. Funciona de modo sutil, objetivando a modelagem da subjetividade dos seus membros internados, no 
que ele se assemelha com a prisão. Acolhe o aluno em sua clausura, confinando-o para formá-lo no contexto institucional.

A educação acadêmica se apresenta como o objetivo oficial do Ateneu. Mas o estabelecimento exerce uma função de atenção aos alunos, membros residentes no estabelecimento, oferecendo mais e menos do que apenas escolarização. É nesse ambiente inclusivo que suas necessidades biológicas, psíquicas e sociais devem ser satisfeitas. O Ateneu também produz mudanças psicológicas no internado, especificando-as e estabelecendo operadores institucionais adequados para obtê-las.

Entendemos que o Ateneu, enquanto estabelecimento, constitui-se num bloco de condições materiais objetivas: sua organização espacial, o regulamento meticuloso que rege sua vida interior, as várias atividades aí desenvolvidas, os diversos personagens que aí vivem e se encontram, cada um com uma função, um lugar etc. Ali, as relações de comunicação e de poder são produtoras de uma subjetividade específica. Acreditamos que a atividade que assegura o aprendizado e a aquisição de aptidões ou tipos de comportamento aí se desenvolve mediante um conjunto de comunicações reguladas (aulas, perguntas e respostas, ordens, exortações, signos codificados de obediência, marcas distintivas do valor de cada um e dos níveis de saber) e de uma série de procedimentos de poder (enclausuramento, vigilância, exame, recompensa e punição, hierarquia piramidal). Como todo espaço institucional fechado, o Ateneu provavelmente funciona a partir de dois elementos essenciais: o aparelho, constituído pelo próprio estabelecimento, e as regras (explícitas e implícitas).

O Ateneu é também um estabelecimento que utiliza mecanismos aparentemente repressivos para controlar a sexualidade dos internados, mas o que realmente parece fazer é incitá-la, acabando por fomentá-la ao proibi-la. Ao encerrar os estudantes como um grupo monossexuado no claustro totalitário, acaba por vê-la emergir perversa e polimorfa.

Sobre sexo, há um enorme silêncio oficial. Há apenas as proibições do regimento indicando as penas para a "imoralidade". 
Porém, se sobre isso não se fala, "isso" fala, numa intensificação dos afetos e dos corpos, num intenso erotismo que, passando pelo flerte, paquera, se configura eventualmente em relacionamentos, em “casos”, em prováveis namoros, na formação de casais apaixonados, em amores secretos, nem sempre discretos, platônicos ou intensamente carnais. Assim sendo, dentro dos muros do internato, sob o interdito sexual, encontramos o frescor do desejo e uma sexualidade fervilhante. Os rapazes podem experimentar diversas práticas amorosas. Parece que a vida no claustro tende a produzir uma exacerbação, intensificação e passagens ao ato das possibilidades neuróticas e perversas dos jovens estudantes.

Em termos de efeitos éticos, a experiência de internação numa instituição total produz resultados muito distantes dos objetivos oficiais que costumam constar em seus estatutos e regimentos (Benelli, 2002; Benelli; Costa-Rosa, 2003b). Ela parece, normalmente, produzir efeitos contrários aos prometidos. Em suas conclusões, Goffman (1987, p.246) afirma que:

Sempre que estudamos um estabelecimento social, verificamos uma discrepância com esse primeiro tema: verificamos que os participantes se recusam, de alguma forma, a aceitar a interpretação oficial do que devem dar e retirar da organização, e, além disso, quanto ao tipo de "eu" e de que mundo que devem aceitar para si mesmos. Onde se espera entusiasmo, haverá apatia; onde se espera afeição, há indiferença; onde se espera frequência, há faltas; onde se espera robustez, há algum tipo de doença; onde as tarefas devem ser realizadas, há diferentes formas de inatividade. Encontramos inúmeras histórias comuns, cada uma das quais é, a seu modo, um movimento de liberdade. Sempre que se impõem mundos, se criam submundos.

As instituições totais tendem a ser (re)produtoras de indivíduos normalizados, modelados numa subjetividade serializada. O Ateneu é um bom exemplar da implementação do dispositivo pedagógico com seus diversos operadores, tal como vemos emergir em Foucault (1999b): escolarização disciplinar produzindo efeitos normalizado- 
res. O seu núcleo subjetivizante estaria centrado numa formação disciplinar, ao mesmo tempo moral e psicológica. A ação institucional incide normativamente sobre as condutas. A subjetividade produzida neste contexto seria caracterizada por traços essencialmente nomatizados e normatizadores, por meio de um jogo de forças (ativas e reativas) que visam à normatização da conduta do outro.

\section{O jovem Törless: violência e subjetividade na instituição total ${ }^{5}$}

A condição de internado, num hospital geral, num hospital psiquiátrico, numa prisão, num colégio interno, num convento ou num seminário, nos parece relevante em si mesma como um assunto que merece ser estudado e compreendido. Sua vida real, atitudes, ideias, sentimentos e conduta devem ser estudados nesse contexto institucional. Acreditamos que o período de internação em um ambiente especial constitui uma parte significativa do período vital total do indivíduo. Esse lapso de tempo no qual o indivíduo vive como internado pode deixar marcas profundas na sua subjetividade.

Dentre as práticas sociais de modelagem da subjetividade, a internação em instituições totais tem sido historicamente uma estratégia extremamente frequente. Tais instituições foram e continuam sendo utilizadas como agências produtoras de subjetividade, modelando-a de acordo com o contexto institucional ao promover relações peculiares entre dirigentes e internados no conjunto das práticas institucionais.

Tomamos como objeto de estudo uma instituição total que Goffman (1987) define como um local que concentra moradia, lazer e a realização de algum tipo de atividade formativa, educativa, correcional ou terapêutica, onde um grupo relativamente numeroso de internados está submetido a uma pequena equipe dirigente que gerencia a vida institucional.

5 Publicado originalmente como artigo: Benelli (2002). 
Relações sociais autoritárias e mesmo violentas podem ser promotoras de um caldo de cultura instável, conflitivo e explosivo. A vida no contexto institucional de uma instituição total (Goffman, 1987) tende a se caracterizar por um alto grau de agressividade e, mesmo, de violência. Uma equipe dirigente arrogante e autoritária pode criar uma vida marcada por uma violência surda e cotidiana, tornando-se incapaz de explicar, controlar ou perceber sua própria implicação na produção de semelhante estado de coisas.

Entendemos a violência como um evento representado por ações realizadas por indivíduos, grupos, classes ou nações que ocasionam danos físicos ou morais a si próprios ou a outros. Agressividade pode ser entendida como "tendências que se atualizam em comportamentos reais ou fantasísticos que visam prejudicar o outro, destruí-lo, constrangê-lo, humilhá-lo, etc." (Laplanche; Pontalis, 1996). Qualquer modalidade de ação, motora ou simbólica, positiva ou negativa, pode funcionar como agressão. A psicanálise atribuiu uma importância crescente à agressividade, mostrando-a em operação desde cedo no desenvolvimento do sujeito, indicando sua ligação complexa com a sexualidade.

Vamos apresentar um exemplo desse fenômeno onde agressividade, violência, sexualidade e sadismo se mesclam de modo complexo em uma instituição total (Goffman, 1987).

Robert Musil (1880-1942) publicou, em 1906, O jovem Törless, baseado em suas experiências escolares. Trata-se de um romance ambientado numa sociedade extremamente autoritária, que narra o desenvolvimento de um adolescente no contexto institucional de um internato escolar, cujos conflitos são urdidos no seio de complexas relações institucionais. Nossa hipótese é que os alunos reproduzem entre si as mesmas relações de dominação e modelagem às quais estão submetidos pela equipe dirigente. Se se tornam opressores, é porque são também oprimidos, reproduzindo as relações sociais de dominação e submissão. Mas não podemos negar a percepção de que os atores principais da história em questão possuem, cada um, modos diversos e específicos de lidar com a lei. 
A perspectiva de Goffman (1987) quanto ao modo de funcionamento dos internados nos auxiliará na compreensão dos acontecimentos narrados. Também nos utilizaremos de algumas hipóteses psicanalíticas para entender a dinâmica dos atores institucionais no romance em questão.

De acordo com Goffman (1987), os internados criam "ajustamentos secundários", práticas que não desafiam diretamente a equipe dirigente, mas lhes permitem obter satisfações proibidas ou conseguir, por meios proibidos, as satisfações permitidas. Os internados "conhecem as manhas" para usufruir uma certa autonomia pessoal, reagindo às pressões ostensivas da equipe dirigente. Poderíamos dizer que os internados inventam as "manhas" e criam também uma "gíria institucional" própria para se comunicarem em segredo. Criam também "controles sociais informais", utilizando a cooptação ou a coerção pela força e violência para evitar que delatores os entreguem à equipe dirigente.

Pelo "processo de confraternização", o grupo dos internados se une, desenvolve apoio mútuo e uma cumplicidade como resistência a um sistema que os forçou à intimidade numa única comunidade igualitária de destino. A gozação coletiva expressa o repúdio geral e vingança contra a autoridade sentida como inimiga.

A solidariedade produz uma infinidade de grupos primários no estabelecimento: panelinhas, facções, ligações sexuais mais ou menos estáveis, a formação de pares, por meio dos quais dois internados passam a ser reconhecidos como "amigos" ou "casal" pelos demais companheiros. Nos casos em que não se pode confiar nos companheiros, que representariam uma ameaça potencial permanente, o internado experimentaria anomia e solidão, apesar de conviver num grande grupo (Goffman, 1987).

\section{Violência e subjetividade contemporânea: observações psicanalíticas}

A psicanálise vem discutindo de longa data a questão da agressividade. Podemos falar sobre algumas tendências que tentam ex- 
plicar esse fenômeno. Uma delas tem sua origem em Freud (1930) e Melanie Klein (Petot, 1991), afirmando que existe uma agressividade inata no homem, semelhante em estatuto à sexualidade, $e$ que busca se manifestar e se satisfazer na forma de destrutividade e autodestrutividade. Mediante uma série de processos psíquicos, essa violência é canalizada, controlada ou posta a serviço de alguma coisa útil. Outras duas tendências levam mais em conta o fator social. Psicanalistas ingleses como Winnicott e outros argumentam que a violência é uma reação à frustração. A violência é uma explosão diante da frustração, de querer algo que não é possível ou não pode ser alcançado. Além disso, de acordo com Lacan (1997), a agressividade e a violência estão relacionadas com a ruptura da imagem narcísica que o indivíduo tem de si mesmo. Quando acontece alguma coisa interna ou externa que ataca a imagem do sujeito, a agressividade surge como uma reação natural, numa tentativa de reconstruir esta autoimagem.

Podemos afirmar que a agressividade não canalizada para fins socialmente úteis, converte-se em violência. Do ponto de vista da agressividade inata, é impossível reduzir a agressividade a zero, seria contrário à natureza humana. A questão é a do manejo dessa violência. Unindo essa perspectiva com as outras, tudo depende fundamentalmente da sociedade por meio de todo seu sistema de ideais e possibilidades oferecidos aos seus membros. Cabe à organização social encontrar formas de canalizar essa violência inata de maneira que ela se torne relativamente inofensiva, sendo utilizada de modo sublimado na própria edificação dessa sociedade.

Existe um limiar de suportabilidade de frustração acima do qual qualquer avanço torna-se impossível. A organização psíquica do indivíduo começa a se esfacelar, ele já não vê perspectivas, a sociedade aponta caminhos que são inviáveis para ele, que recebe constantemente mensagens do meio social de que é um desqualificado. Necessidades básicas de segurança e bem-estar são negadas constantemente e isso, evidentemente, aumenta a capacidade e a disposição do indivíduo para atacar com violência o primeiro que passar. Por que respeitar as regras e leis de uma sociedade que não 
retribui ao indivíduo, que abriu mão da violência contra o semelhante, num pacto social? Ele abre mão da violência, sublima suas pulsões agressivas e destrutivas e não recebe em troca os benefícios prometidos, permanecendo numa posição de exclusão, sem aceder ao usufruto dos bens sociais (Pellegrino, 1987).

Do ponto de vista de Lacan, também podemos observar fenômenos de violência individual ou coletiva que visam manifestamente restaurar a imagem que cada membro de um grupo tem, com relação a outros indivíduos ou grupos. Quando determinado grupo acusa outro de inferior, o que ele pretende é garantir que ele mesmo não seja inferior. Essa dimensão psíquica da agressividade e da violência parece inevitável e compete à sociedade se organizar de maneira a diminuir os riscos que ela traz.

Mas essa tarefa de gerenciamento social ou coletivo da agressividade é um trabalho paradoxal, numa sociedade que está incorporada no Capitalismo Mundial Integrado. O próprio mercado parece funcionar vorazmente, com uma agressividade que se expressa num confronto sem mediação. Uma Formação Social não consegue canalizar a agressividade quando ela própria é promotora dessa situação e exacerba a frustração até um grau intolerável para seus membros. Ela própria pode inviabilizar ou frustrar o esforço que um indivíduo faz para pertencer civilizadamente ao seu conjunto. O ser humano é capaz de tolerar grandes doses de sofrimento, mas em nome de alguma coisa, com a esperança que sua dor não será em vão e que as coisas vão mudar para melhor, com uma promessa de que isso em algum momento vai cessar. Mas, não apenas a sociedade capitalista não respeita essa promessa, que é feita quando alguém nasce no seu seio, como ela está deixando de ser formulada.

Não é espantoso então que as pessoas comecem a fazer justiça com as próprias mãos. Isso pode ser realizado por meio do mecanismo de projeção, que consiste em encarnar num outro indivíduo ou grupo tudo aquilo que se considera ruim ou um mal, que não se pode tolerar nem suportar. O objeto torna-se insuportável e pode ser maltratado e até destruído porque ele está recoberto pela própria 
imagem do mal, que foi depositada nele pelo outro. $\mathrm{O}$ alvo da projeção do mal torna-se também odioso porque ele aparece como um transgressor, capaz de experimentar a realização dos desejos mais secretos e caros dos seus inimigos, mas que lhes são interditados. A destruição do inimigo intolerável assim produzido realiza-se em meio a uma fúria coletiva que tem fortes efeitos catárticos: "não sou como esse, sou melhor do que ele, sobre o qual tenho direito de vida e morte". Ora, na base desses fenômenos estão presentes fatores psicossociais.

A partir das análises das formas do Sintoma Social Dominante, a violência pode ser considerada como variante de um tipo de relação com a lei, uma modalidade de subjetividade específica. Uma forma de ação, de reação, uma estratégia de sobrevivência em ambientes hostis. Provavelmente, ambientes de reclusão tendem a promover a emergência de possibilidades subjetivas que de outro modo raramente se manifestariam.

\section{A carreira moral do jovem Törless no internato escolar}

Goffman (1987) utiliza o termo "carreira moral" em um sentido amplo, com a finalidade de indicar qualquer trajetória percorrida por uma pessoa ao longo de sua vida, permitindo ainda uma perspectiva tanto dos aspectos mais íntimos e pessoais, quanto da posição oficial, jurídica e pública do indivíduo, dentro de um complexo institucional. A "carreira moral" indica o processo da vida toda do indivíduo, em direção tanto ao sucesso quanto ao fracasso, dentro do estabelecimento. Esse processo tem momentos típicos, tais como início da vida institucional, crises, evoluções, desenvolvimentos de adaptação, de rebeldia, de submissão, de ruptura etc.

É no contexto institucional do internato escolar que Törless tem como amigos Reiting e Beineberg, dois rapazes bastante singulares.

Reiting guardava diários secretos, repletos de audaciosos planos para o futuro, e anotações minuciosas sobre o motivo, a origem, a encenação e o transcurso das incontáveis intrigas que provocava 
entre os colegas. Pois nada divertia mais a Reiting do que atiçar pessoas umas contra as outras, alimentando-se dos agrados e das adulações forçados que extraía delas, por trás dos quais sentia a resistência do ódio de suas vítimas. - Isso me serve de exercício - dizia como única desculpa, com um sorriso amável. Também, como exercício, lutava boxe quase diariamente em algum lugar afastado, contra uma parede, uma árvore ou uma mesa, para fortalecer os braços e dar resistência às mãos, fazendo com que criassem calos. (Musil, 1986, p.51-2)

Reiting sabia impor-se, era um tirano e mostrava-se impiedoso com quem lhe resistisse. Seus amigos variavam a cada dia, embora a maioria se achasse sempre do seu lado. Nisso era talentoso. Sua amizade com Beineberg era mais uma aliança oportuna:

Há um ou dois anos realizara uma grande campanha contra Beineberg, concluindo com a derrota deste. Beineberg ficara bastante isolado, ainda que não perdesse seu sangue frio, espírito crítico e capacidade de instigar antipatias entre os outros. Faltava-lhe contudo, a amabilidade e o talento necessários à conquista das pessoas. Sua indiferença, suas maneiras de filósofo cheio de unção provocavam desconfiança na maioria das pessoas. Presumiam que no fundo de sua personalidade havia algo exagerado e desagradável. Mesmo assim, causara grandes problemas a Reiting e a vitória deste fora quase casual. Desde então, mantinham-se unidos por interesses comuns. (ibidem, p.53)

Törless estava inserido nesse universo de estudantes e constatava diariamente o que significava desempenhar o papel principal num Estado, pois, num estabelecimento assim, cada sala de aula pode perfeitamente ser considerada um pequeno Estado em si. Goffman (1987) afirma que estabelecimentos totais funcionam mais ou menos como um Estado e sua equipe dirigente tem que enfrentar problemas de um modo parecido aos que têm os governantes de Estados. Törless, sendo mais jovem que seus dois colegas ditadores, 
mantinha com eles uma relação de discípulo, ajudante e protegido, embora gostassem de ouvir sua opinião.

Törless era inteligente e ninguém era tão hábil quanto ele em prever as diferentes possibilidades de comportamento de uma pessoa em determinadas condições. Só quando se tratava de tomar uma decisão, de assumir os riscos de uma escolha entre várias opções psicológicas e agir, ele falhava, perdia o interesse e a energia. Seu papel como uma espécie de chefe de estado-maior secreto, porém, o divertia. Tanto mais por ser quase a única coisa a trazer alguma vida ao seu profundo tédio. (Musil, 1986, p.53-4)

\section{Violência e sexualidade no contexto institucional}

Reiting descobriu que Basini, outro estudante, roubara dinheiro de Beineberg para saldar dívidas que contraíra com outros colegas. Basini vivia endividado, emprestando de uns para pagar a outros, sua mãe era viúva e não dispunha de muito dinheiro. Reiting havia emprestado a Basini e cobrou o que esse lhe devia. Como o outro lhe pediu um prazo, Reiting passou a investigar a vida de Basini e descobriu suas dívidas permanentes. Reiting exigiu então que Basini lhe trouxesse o dinheiro ou teria que obedecer cegamente ao seu credor. Basini ficou encabulado e prometeu trazer o dinheiro no dia seguinte. Mas conseguiu apenas uma parte do dinheiro. Reiting blefou com Basini, dizendo ter descoberto que ele havia roubado dinheiro dos colegas e ameaçou-o com uma denúncia que podia causar sua expulsão do colégio.

A situação era de guerra psicológica, pois Reiting não tem certeza de que Basini roubara mesmo Beineberg, mas o pressiona com sutileza, com um sorriso zombeteiro nos lábios, até conseguir arrancar uma confissão do colega. Basini disse que pegara o dinheiro apenas como empréstimo oculto e que pretendia devolvê-lo o quanto antes, pediu que Reiting não dissesse que ele roubara e que se apresentava formalmente como seu escravo. 
Reiting se reuniu com Törless e Beineberg no seu refúgio secreto, no sótão do colégio (ajustamento secundário), para deliberar sobre o futuro de Basini. O trio não chegou a um acordo: Törless afirmava que Basini era um ladrão e que devia ser castigado, denunciado, afastado do internato; Reiting não concordava, dizendo que "Basini está em nossas mãos, podemos fazer com ele o que bem entendermos. E caso ele se rebele, podemos lhe mostrar quem é o senhor aqui. A baixeza dele nos diverte" (ibidem, p.63).

Beineberg mostrou-se indiferente e deixou a decisão com os outros dois.

Aceitaram, portanto, uma sugestão de Reiting. Decidiram manter Basini sob vigilância, de certa forma sob tutela, oferecendo-lhe uma oportunidade de trabalhar para sair daquela situação. Dali por diante, seus gastos e ganhos seriam severamente conferidos, e suas relações como os outros alunos dependeriam da permissão dos três. (ibidem, p.64)

Essa experiência deixou Törless perplexo diante dos dois colegas, "teve medo deles - mas como tememos um gigante que sabemos cego e tolo..." (ibidem, p.65).

No dia seguinte, Basini foi colocado sob tutela. Não sem alguma solenidade. Aproveitaram uma hora da manhã durante a qual escaparam aos exercícios ao ar livre num extenso gramado do parque. Reiting fez uma espécie de longo discurso. Advertiu Basini de que ele estragara sua existência, de que na verdade deveria ser denunciado; ele devia unicamente a uma graça especial o fato de que por enquanto o livrassem da vergonha de uma expulsão. Depois puseram-no a par das condições especiais. Reiting assumiu a vigilância dos ganhos de Basini. Este empalideceu e não disse uma palavra e pelo seu rosto não se conseguia ver o que se passava em sua alma. Törless julgara a cena alternadamente de muito mau gosto e muito importante. Beineberg prestara mais atenção em Reiting do que em Basini. (ibidem, p.65-6) 
Basini é descrito como um adolescente belo, ingênuo, vaidoso e inconsequente, não conseguia resistir a nada que desejasse e sempre era surpreendido pelas coisas que fazia.

Beineberg continuou observando Reiting e descobriu que ele o estava traindo e também traía Törless. No esconderijo do sótão, Beineberg comenta com Törless que desde o começo Reiting havia defendido Basini de modo intenso. Alguém baixo como Basini deveria ser expulso imediatamente. Foi de propósito que Beineberg não concordou com a posição inflexível de Törless, pois queria descobrir o que mais estava em jogo. Ele lembrou Törless de um caso de envolvimento sexual entre os rapazes que culminou na expulsão de vários deles. Havia naquela turma um rapazinho muito belo pelo qual todos se apaixonavam. Reiting estava fazendo a mesma coisa com Basini. Beineberg os seguiu e descobriu o que faziam.

Beineberg possui uma teoria sobre a superioridade de uns seres sobre os outros, alguns nasceram, de acordo com uma ordem universal, para uma vida singular, resistente, e outros nasceram apenas por acidente, por acaso, à margem e sem qualquer importância.

Num ser humano, ela coloca essa dureza na personalidade, na consciência, na responsabilidade que ele sente por ser parte da alma universal. Se uma pessoa perde essa noção, perde-se a si mesma. E quando um ser humano perdeu a si mesmo, renunciou a si, perdeu também aquela coisa especial, singular, para a qual a Natureza o criou como ser humano. E em nenhum outro caso como este poderíamos estar tão seguros de que estamos lidando com algo inútil, com uma forma vazia, algo há muito abandonado pela alma universal. (ibidem, p.74)

Reiting está nas mãos de Beineberg, que de posse desse segredo do seu rival pode prejudicá-lo, pode ameaçá-lo com a expulsão do internato, acenando com a possibilidade de uma denúncia. Törless fica assustado diante da frieza malévola do companheiro e sente-se igualmente ameaçado por Beineberg, como se o destino de Reiting fosse também o seu. Beineberg decide não fazer nada contra Rei- 
ting, já que ele agora não representa mais perigo. Mas decide não denunciar Basini, quer castigá-lo pessoalmente por causa de sua arrogância. Quer aprender com a experiência de torturar Basini.

Não precisa ficar assustado - diz Beineberg a Törless - não é tão ruim assim... não se deve ter consideração alguma com Basini... A decisão de torturá-lo depende unicamente de nossa necessidade de agir de um ou de outro modo... Reiting também não vai largar o caso, porque para ele trata-se igualmente de algo de valor especial ter uma pessoa nas mãos e poder se exercitar, usá-la como ferramenta. Ele deseja dominar e faria com você exatamente como faz com Basini, se por acaso topasse com você... Eu, em contrapartida, tenho, como você, a sensação de que, afinal, Basini também é apenas um ser humano. Também sinto que alguma coisa em mim sofreria com a crueldade que eu praticasse contra ele. Mas é exatamente isso que importa! Realmente um sacrifício! Como vê, também estou preso a dois fios. Um deles, obscuro, me leva à omissão piedosa, que se contrapõe às minhas mais claras convicções. $\mathrm{O}$ outro atravessa diretamente a minha alma, chegando ao mais profundo entendimento interior e me liga ao Cosmos. (ibidem, p.78-9)

De acordo com sua teoria sobre a natural diferença entre os seres humanos relevantes e os insignificantes na ordem universal das coisas, ele decide superar o impulso de deixar Basini livre, como se isso fosse um preconceito de origem externa e inferior, do qual deve se libertar.

Exatamente porque me custa torturar Basini - quero dizer, degradá-lo, rejeitá-lo -, exatamente por isso é bom. Pois exige sacrifício. Surtirá efeito purificador. Devo isso a mim mesmo; e preciso aprender com Basini, diariamente, que ser apenas humano nada significa, é mera aparência, uma macaquice... (ibidem, p.80)

Törless fica confuso e excitado com as ideias do perigoso amigo que Beineberg se revela. Os dias prosseguem relativamente nor- 
mais e Törless anda às voltas com emoções e vivências adolescentes, indefiníveis em suas reflexões solitárias.

Os três rapazes se reúnem no sótão e Basini é humilhado verbalmente por Beineberg. Basini esperava ser defendido por Reiting, mas esse o esbofeteou e, juntamente com Beineberg, o despiu e deram-lhe uma surra. Törless não fez nada, paralisado, em transe diante do espetáculo, observando suas próprias emoções diante do evento. Foi tomado por uma poderosa excitação sexual. Terminada a sessão de espancamento, Reiting mandou Basini se sentar numa das traves de madeira do telhado e começou a falar.

"Decerto você já estava achando que tinha se safado muito bem, não? Decerto pensou que eu ajudaria você? Bem, se foi assim, enganou-se. O que eu fiz com você foi apenas para ver até onde ia sua baixeza." Basini esboçou um gesto de protesto. Reiting ameaçou saltar outra vez sobre ele. Então disse: "Mas pelo amor de Deus, suplico a vocês, não tive outra saída!” Reiting gritou para que ele calasse a boca. "Estamos fartos de suas desculpas. Sabemos muito bem quem você é, e vamos agir conforme..." Depois de um breve silêncio, Törless disse baixinho: "Diga: eu sou um ladrão". Basini arregalou os olhos assustados. Beineberg deu uma risada de aprovação. Depois de resistir um pouco, Basini, sob ameaças, o disse. Beineber e Reiting disseram a Törless, rindo divertidos: "Você teve uma boa ideia, filhote." - e para Basini: "E agora você dirá imediatamente: eu sou um animal, um animal que rouba, sou um animal, um ladrão, o porco de vocês!" E Basini disse tudo, sem se interromper, os olhos cerrados. (ibidem, p.97-8)

\section{A paixão e o desejo sexual adolescente no internato}

A intensidade da sexualidade adolescente vai inundando Törless e aos poucos ele vai tomando consciência da forte atração que sente por Basini.

Sempre que essa sensação imprecisa o dominava, sua atenção perdia aquele atributo pacato com que se acompanha o desenrolar 
de uma experiência científica. Parecia que de Basini emanava um fluído físico, uma excitação, como quando se dorme ao lado de uma mulher de quem se pode, a qualquer momento, tirar o cobertor. Era como um arrepio no cérebro, nascido da consciência de que basta estender a mão: a mesma coisa que muitas vezes leva jovens casais a excessos sensuais muito além das exigências de seus corpos. (ibidem, p.127)

Por ocasião de um feriado, o internato ficou quase vazio e Törless permaneceu ali. Basini também. O desejo de abordar Basini torturou Törless um dia inteiro. À noite, Törless foi até a cama de Basini e acordou-o. Basini o acompanhou até o esconderijo, onde ficou nu diante dele.

Törless recuou um passo involuntariamente. A súbita visão do corpo nu, branco como a neve, atrás do qual o vermelho das paredes parecia sangue, deixava-o ofuscado e perplexo. Basini tinha um belo corpo - quase nenhum traço de virilidade, de uma magreza casta e esguia, como a de uma donzela. Törless sentia essa nudez incendiar seus nervos como alvas labaredas ardentes. Não conseguia evitar o poder de tamanha beleza... Ali, porém, a arte chegava pelos caminhos do sexo. Secreta e súbita. Um sopro cálido e perturbador se desprendia daquela pele nua, aliciante, macia e plena de sensualidade. Vibrava nela também algo solene, quase sagrado. (ibidem, p.134)

Törless reage ao desejo que o atravessa, como se despertasse de um delírio. Exige que Basini se vista e o interroga, descobrindo então que Beineberg e Reiting surravam e abusavam sexualmente de Basini. Törless tenta fazer Basini perceber que não é obrigado a se submeter aos outros dois, que abusam dele. Basini acredita que não tem outra saída e se submete a tudo porque prometeram que logo vão perdoá-lo e tudo será esquecido, ele quer apenas voltar a ser um rapaz decente novamente. Törless descobre que Reiting e Beineberg poderiam agir com ele com faziam com Basini, criando 
uma intriga contra ele. "Havia algum perigo... escondido em algum lugar... espreitando Törless... cada passo seu podia cair numa armadilha, cada noite podia ser a última antes da batalha. Essa ideia causava uma insegurança insuportável" (ibidem, p.136). Basini não era capaz de perceber a própria implicação na produção da situação na qual estava envolvido e Törless mergulha em seus próprios pensamentos.

De volta ao dormitório, Törless adormece e Basini vai até sua cama. Törless resiste um pouco, indeciso e imerso em dúvidas, mas sucumbe ao desejo e à sedução do outro.

Então Törless desistiu de procurar palavras. A sensualidade que se esgueirara para dentro dele paulatinamente nos momentos de desespero despertara agora com toda a intensidade. Deitava-se ao lado dele, nu, cobrindo-lhe a cabeça com um manto negro e macio. Sussurrava em seu ouvido suaves palavras de resignação e com seus dedos cálidos afastava todas as perguntas e deveres, como se fossem vãos. Sussurrava: na solidão tudo é permitido. Só no momento em que estava sendo arrastado, despertou por um segundo e agarrou-se desesperado à ideia: "Isso não sou eu! Não sou eu! Amanhã, só amanhã, serei eu novamente! Amanhã..." (ibidem, p.147)

Esse foi o estopim para a temporada apaixonada que se seguiu: Törless e Basini passaram a encontrar-se às escondidas com frequência, entregando-se ao desejo que os consumia. Reiting e Beineberg mantinham-se distantes de Basini e Törless os vigiava, sem ter paz, consumido pelo ciúme.

Beineberg mostrava-se sombrio e fechado; quando falava, eram alusões misteriosas a alguma coisa iminente. Reiting aparentemente voltara seu interesse para outras coisas; com a habilidade costumeira, tramava a rede de alguma intriga, tentando conquistar alguns através de pequenos agrados e assustando outros ao descobrir seus segredos através de alguma artimanha. (ibidem, p.148) 
O amor adolescente de Törless por Basini era algo confuso, um misto de desejo e repulsa por consentir em desejos percebidos como degradantes.

No começo fora apenas a nudez do esbelto corpo de adolescente que o ofuscara. A impressão foi a mesma que teria se visse as belas formas de uma jovem, ainda livres de qualquer aspecto sexual. Um assombro. Um impacto. E a pureza que involuntariamente emanava daquela sensação era o que usava a máscara do afeto - essa sensação maravilhosa, inédita, inquieta, na sua relação com Basini. Todo o resto pouco tinha a ver com ele. O resto do desejo já existira antes, era a sensualidade secreta, desorientada, não dirigida para ninguém em especial, a melancólica sensualidade de um adolescente que amadurece, parecendo a terra úmida, negra e fértil da primavera, e as escuras águas subterrâneas que precisam apenas de uma ocasião eventual para romper as comportas... (ibidem, p.149)

A experiência de Törless com Basini foi a ocasião para que naqueles esconderijos solitários e secretos se reunissem todos os desejos ocultos, sufocantes e rebentassem, derramando-se sobre o amante como impulsos obscuros. Mas uma luta interior permanente entre o desejo e a repulsa não permitia a Törless ter sossego. Vivia medroso, sobressaltado, em pânico de que descobrissem sua paixão, com grande desgaste em meio ao vendaval de emoções angustiantes e solitárias. Essa sexualidade adolescente fervilhante e patente, que se concretiza em casos e paixões arrebatadoras entre indivíduos do mesmo sexo, encontra nas peculiares condições de vida do internado sua causa.

Com forças jovens e impetuosas retidas por trás de muros cinzentos, a fantasia multiplicava imagens sensuais que punham muitos dos rapazes fora de si. Certo grau de devassidão passava até por ser uma qualidade viril e ousada; era como se conquistassem os prazeres proibidos. (ibidem, p.155) 


\section{O auge da violência: ameaças e pressão psicológica}

Reiting e Beineberg, irritados porque Basini já não os obedecia como antes, nem parecia sofrer com a obediência, decidiram acabar com ele de uma vez. Reiting pensava em degradá-lo de modo insuportável e talvez entregá-lo à sua classe.

Seria o mais sensato. Se cada um contribuir com um pouco, poderemos fazê-lo em pedacinho. Aliás, gosto desses movimentos de massa. Ninguém faz nada de especial, e ainda assim as ondas se erguem cada vez mais alto, até se abaterem sobre as cabeças de todos. Vocês vão ver, ninguém se moverá e ainda assim haverá uma tempestade gigantesca. Para mim será uma diversão extraordinária promover uma coisas dessas. (ibidem, p.157)

Mas antes do golpe de misericórdia, ainda queriam se aproveitar mais um pouco de Basini, usando ameaças e surras. Törless sofre com a possibilidade de que Reiting e Beineberg descubram seu envolvimento com Basini e o tratem do mesmo modo. Deixou que tudo acontecesse como os outros dois queriam. Seus sentimentos por Basini já tinham se esfriado completamente e a situação o livrava de oscilar entre o desejo e a vergonha, pois não conseguia se livrar por si mesmo. Além disso, temia que as humilhações preparadas para Basini também o atingissem.

Reiting e Beineberg levaram Basini para o sótão mais uma vez, onde o humilharam e espancaram na presença de Törless, que assistiu a tudo, calado. Törless não se envolveu e deixou que os outros dois fizessem com Basini o que quisessem. Eles continuaram abusando e espancando o rapaz.

Algum tempo depois, Basini procurou por Törless, pedindo-lhe ajuda, implorando porque já não suportava mais os tormentos aos quais era submetido. Törless tentou se esquivar, dizendo que a culpa era de Basini, por estar nessa situação. Eles marcaram um encontro no sótão à noite. Lá, Törless repetiu para Basini que não ia ajudá-lo. Reiting os surpreendeu escondidos ali e exigiu satisfações. 
Törless disse que Basini o chamara ali para pedir proteção, mas ele havia recusado e não queria mais saber daquela história. Reiting e Törless discutiram, trocaram insultos e romperam relações. Törless entendeu que agora um perigo real o ameaçava pelas costas.

Dias depois, Reiting e Beineberg, irritados com os insultos, abordaram Törless e exigiram que ele fosse assistir a um último castigo de Basini no esconderijo, antes de entregá-lo para a turma da classe. Diante da recusa de Törless, passaram a ameaçá-lo.

"Meu caro Törless, se você se voltar contra nós e não aparecer lá vamos fazer com você o mesmo que com Basini. Sabe muito bem em que situação Reiting encontrou você lá em cima junto dele. Isso basta. O fato de termos feito mais ou menos a mesma coisa com Basini não lhe servirá de nada. Vamos usar tudo contra você, que nesses assuntos é bobo e inseguro demais para nos vencer. Portanto, se não mudar de ideia em tempo, vamos acusar você de cumplicidade com Basini diante de todos os colegas da classe". (ibidem, p.175)

À noite, não acompanhou os três, quando deixaram o dormitório coletivo. Ficou ali em sua cama, martirizado por fantasias terríveis, desejando ardentemente livrar-se daquela confusão. Quando regressaram e adormeceram, Törless rabiscou um bilhete para Basini e colocou-o na mão do rapaz.

"Amanhã você será denunciado aos colegas e vão acontecer coisas terríveis com você. A única saída é entregar-se ao diretor. De qualquer modo ele ficará sabendo; só que antes disso dariam uma surra tremenda em você. Atribua toda a culpa a R. e a B. e me deixe fora disso. Está vendo que desejo salvar você”. (ibidem, p.177-8)

\section{A organização da sessão coletiva de agressão e a reação da equipe dirigente}

No dia seguinte, Törless viu Beineberg e Reiting irem de um colega a outro; ao redor deles formavam-se grupos, que sussurravam agitados... o nervosismo crescera... talvez tivessem acrescentado 
mentiras... primeiro sorriam, depois alguns ficavam sérios, lançando olhares indignados para Basini. Por fim a sala de aula ficou pesada de um silêncio sombrio, ardente, prenhe de impulsos sinistros. Por acaso tiveram a tarde livre. Todos se reuniram no fundo da sala, junto dos armários, e chamaram Basini (ibidem, p.179). Fecharam as portas, colocaram vigias, ordenaram que Basini se despisse, causando grande prazer à turma. Enquanto Reiting lia em voz alta cartas da mãe de Basini, risadas obscenas e piadas indecentes emergiam do grupo.

De repente, alguém empurrou Basini. Outro sobre o qual ele caiu, empurrou-o de volta, em parte com raiva em parte de brincadeira. Um terceiro o passou adiante. E de repente, nu, a boca escancarada de pavor, Basini voou como uma bola pela sala em meio às gargalhadas e aos apertos de todos - de um lado a outro - seu corpo abriu-se em feridas nas quinas dos bancos, e ele caiu de joelhos, esfolando-os até sangrar; por fim, ensanguentado, empoeirado, os olhos esgazeados como os de um animal, caiu de vez no chão, enquanto se fazia um súbito silêncio e todos se aproximaram para vê-lo ali estendido. (ibidem, p.179)

Decidiram na noite seguinte amarrar Basini em uma cama e açoitá-lo ali, mas de manhã cedo, o diretor entrou na sala de aula, acompanhado pelo regente da classe e de dois professores. Basini foi retirado da sala e isolado dos demais. O diretor pronunciou um sermão irado sobre as crueldades cometidas e ordenou uma severa investigação. Basini havia se entregado pessoalmente, sem incriminar Törless.

Ninguém suspeitava de Törless, nem Beineberg e Reiting pensavam na possibilidade de que ele fosse o delator. Estabeleceu-se um pequeno processo inquisitorial e todos os alunos foram chamados individualmente para um interrogatório. Sentindo-se incapaz de enfrentar o inquérito, Törless fugiu do internato. A polícia saiu à procura do rapaz, enquanto a investigação se processava. Reiting e Beineberg jogaram toda a culpa em Basini, afirmando que tudo o que fizeram foi com o intuito de regenerá-lo, mas ele não se corrigiu. Toda a classe jurou que maltratara Basini, provocada pelo 
deboche com que ele respondia à bondade dos colegas. Trava-se de uma comédia bem armada. Basini manteve-se calado, devido às novas ameaças de Beineberg e Reiting.

Törless foi encontrado e trazido de volta. Sua fuga era um enigma no caso Basini. Os colegas o preparam e ele foi enfrentar o interrogatório da comissão de professores, na residência do diretor. Um dos professores redigia a ata do processo. Törless enrolou-se confusamente nas suas explicações, sem esclarecer nada. Diante do impasse, resolveram despedir Törless, que nesse ínterim já havia solicitado a seus pais sua saída do internato. Basini foi expulso e a vida escolar retomou seu curso normalmente. Do internato, Törless levou o aprendizado das inesperadas potencialidades do polimorfo desejo que atravessa o ser humano.

Quando a equipe dirigente foi informada dos acontecimentos envolvendo Basini, vemos o estabelecimento lançar mão das técnicas disciplinares baseadas no "exame", conforme Foucault (1999a). As autoridades instalam um processo inquisitorial para apurar os acontecimentos e interrogar os alunos. Podemos perceber aí como o sistema escolar está atrelado a um "micropoder judiciário", tal como afirma Foucault (1999b). Notamos que há todo um jogo de forças, uma luta, um estado de guerra no próprio grupo dos internados: impossível não notar a agressividade e a sexualidade que ali fervilham, na surdina. Os "problemas de governante", enfrentados pela equipe dirigente, revelam que ela sofre influências e tem que administrar as ações e reações geradas pelo grupo dos internados.

\section{O internato como uma miniatura da sociedade}

No internato escolar descrito por Musil (1986) encontramos uma sociedade em miniatura. Os fenômenos sociais, em estado nascente, mais ou menos desenvolvidos, podem ali ser apreciados: a circulação da informação, o exercício da autoridade e seus efeitos disciplinares, as pressões, os mecanismos adaptativos dos indivíduos, a tensão entre interesse geral e satisfação de necessidades individuais, o conflito entre as necessidades do estabelecimento e 
a preservação dos particularismos individuais e da espontaneidade criadora, as normas, os códigos, as crenças, a linguagem comum, a hesitação entre a tolerância e o ostracismo em relação aos desviantes (sobretudo sexuais) e as "panelinhas" que enfraquecem a unidade coletiva. Ainda, o antagonismo das personalidades dominantes, geralmente reforçados pelos grupos correspondentes, as relações de forças oscilando nos eixos maioria-minoria-unanimidade, os bodes expiatórios, os suspeitos, os heróis, os braços-fortes, os subalternos, os delatores, perseguidos e algozes. Nesse microcosmo experimental, poderíamos estudar "in vitro" vários problemas de Filosofia Política, Sociologia dos grupos, História e Psicologia Social.

Do ponto de vista psicológico, a comunidade do internato escolar pode ser estudada como um laboratório para outras experimentações: além da perspectiva institucional, dos objetivos confessos, das tarefas cumpridas em comum, podemos ver como o grupo, no contexto institucional, se configura no encontro de pessoas, de sujeitos, como um local de confronto e de laços afetivos. As oposições e as afinidades de caráter florescem na comunidade. Os desejos individuais, sempre presentes na surdina, esperam passivamente ou reclamam com violência sua realização: apelo a ajuda, proteção, vontade de poder, exibicionismo, ataque que denigre, curiosidade, rivalidade, admiração, idolatria. O narcisismo de cada um nela experimenta doces vitórias e também feridas amargas: os outros são reduzidos a objetos do meu desejo ou os narcisismos alheios me infligem feridas sem querer (e às vezes, propositalmente), apenas por sua própria existência.

\section{Um percurso singular num movimento religioso católico de matiz totalitário ${ }^{6}$}

Desenvolvemos uma pesquisa que visa entender a produção da subjetividade no contexto institucional de alguns movimentos e

6 Publicado originalmente como artigo: Benelli e Costa-Rosa (2006). Agradecemos ao colega Prof. Dr. Abílio da Costa-Rosa por sua colaboração imprescindível com este artigo. 
grupos religiosos católicos ${ }^{7}$ e tomamos, para isso, o Movimento dos Focolares como objeto específico de estudo. Apresentaremos a seguir um estudo sobre a condição de internado que experimenta um jovem que, ao ingressar no movimento religioso católico Focolares, vive durante dois anos no contexto institucional de uma aldeia do grupo, onde realiza sua iniciação e passa a pertencer ao movimento.

O Movimento dos Focolares foi fundado por Chiara Lubich em Trento, Itália, em 7 de dezembro de 1943. Em 29 de junho de 1990, seus estatutos gerais atualizados foram aprovados por Decreto do Conselho Pontifício para os Leigos da Igreja Católica, declarando- o como "associação de fiéis de caráter privado e universal de direito pontifício". Seu carisma é a "espiritualidade da unidade" e conta com mais de cem mil membros espalhados pelos cinco continentes, dividindo-se em 75 regiões. A presidente é Maria Voce (eleita em 2008, quando Chiara Lubich, então presidente, faleceu), auxiliada por um vice-presidente e um conselho com sete membros. O Movimento dos Focolares é composto por famílias, jovens, sacerdotes, religiosos e religiosas de diversas congregações, além de bispos. As seções masculinas e femininas dos focolarinos, consagrados na pobreza, castidade e obediência, vivem em comunidades e constituem a base de sustentação do grupo. O Movimento dos Focolares tem diversas atividades de amplo alcance: "Famílias Novas", Humanidade Nova", "Movimento Paroquial", "Movimento Diocesano", "Jovens por um Mundo Unido", "Movimento Juvenil pela Unidade". Tem fortes incursões nos âmbitos da cultura, da educação, da economia e da política, contando também com poderosa atividade editorial. O Movimento dos Focolares está presente em 194 países dos cinco continentes, com centros estabelecidos em oitenta países. Fazem parte do movimento cerca de 120 mil pessoas, na qualidade

7 No conjunto desses grupos religiosos, incluímos o Movimento Focolare (Oliveira, 1988; Silva, 2000; Urquhart, 2002; Lubich, 2003; Fondi e Zanzucchi, 2004); Comunhão e Libertação (Rondoni, 1999; Urquhart, 2002), Neocatecumenato (Vicente, 1988; Cordonnier, 1995; Blazquez, 1996; Pasotti, 1999; Urquhart, 2002; Fernandez, 2004) e Opus Dei (Le Tourneau, 1985; Prada, 1989; Perez, 1992; Rodríguez et al., 1993; Ferreira, Lauand e Silva, 2005). 
de membros, e cerca de um milhão e meio de aderentes e simpatizantes. Os Centros Mariápolis, lugares destinados aos encontros e à formação de novos integrantes, estão espalhados em 46 países (Lubich, 2003, p.443-6).

A análise do estabelecimento religioso e dos processos empreendidos por ele se dá a partir dos dados de um caso que nos é apresentado em um relato escrito (Urquhart, 2002); daí a necessária recorrência a esse autor na mesma obra. No seu relato, é perfeitamente possível distinguir o que são dados de experiência, vivência e observação, daquilo que é sua própria análise de tais dados. A riqueza de elementos descritivos nos parece um dos aspectos mais relevantes dessa obra. Trabalhamos a partir do seu depoimento pessoal, fazendo de sua experiência no Movimento dos Focolares um caso singular (Aguiar, 2002, p.139). Nele, procuramos verificar como funciona o estabelecimento (grupo religioso), como é a vida no próprio estabelecimento e como o sujeito a experimenta, entende e responde a ela. Para isso, procuramos considerar tanto a realidade institucional do internato Focolares quanto à subjetividade que seu funcionamento promove, manifestando-se, essa, em dinâmicas psicológicas específicas.

Vejamos algumas características comuns entre o caso relatado por Urquhart (2002) e as instituições totais, que fundamentam nossa hipótese de que ele tem estatuto de caso singular. As características do funcionamento institucional, seus mecanismos de controle e administração dos internos e a relação entre esses e a equipe dirigente são as mesmas das instituições totais (Benelli; Costa-Rosa, 2003a, 2003b): isolamento do mundo exterior, supressão da privacidade dos indivíduos internados, segregação entre os gêneros, ausência de documentos escritos sobre objetivos e regulamento, controle exaustivo de todas as atividades e da rotina de cada um, entre outros. Também está presente todo um conjunto de práticas e efeitos que designamos como processos de subjetivação que, do mesmo modo, são absolutamente congruentes com os das instituições totais: rituais de mortificação do "eu”, negação da história pregressa (desterritorialização social e subjetiva) e instau- 
ração de outra identidade radicalmente diferente da anterior, com características totalitárias. Observaremos, ainda, a presença do retorno, nos institucionalizados, de uma série de efeitos subjetivos de natureza sintomática, expressos em performances radicais e maciçamente identificatórias, como a atitude fanática. A propósito desse aspecto, é conveniente fazer já uma distinção entre identificação e identidade: a última supõe um mínimo de identificação e é a base para performances não imitativas, portanto singularizadas (Guyomard, 1996, p.12-13). Finalmente, constatamos um outro conjunto de performances sintomáticas que geram saídas agonísticas de natureza disruptiva, do tipo "passagens ao ato", e mesmo fugas do estabelecimento ou deserções da ordem nos estabelecimentos em que isso é possível.

Se ficar, portanto, demonstrado que o estabelecimento aqui estudado possui as características das instituições totais, visto tratar-se de um estabelecimento religioso, cremos estar suficientemente indicada a possibilidade de sua representatividade, como caso singular, em relação a um conjunto amplo de instituições religiosas com características de instituições totais (Benelli; Costa-Rosa, 2002, 2003a, 2003b). É nessa perspectiva que tomaremos o relato de Urquhart (2002) como descritivo das características da organização Movimento dos Focolares e dos processos de subjetivação de que são objeto os sujeitos que aceitam ingressar nela.

Pensamos que esta análise já se justificaria pelas possibilidades de compreensão desse movimento particular, entretanto veremos que várias das suas características são extensíveis a outras instituições de natureza e funções similares, que têm sido designadas como movimentos neofundamentalistas leigos (Galindo, 1994, p.306-12; Martelli, 1995, p.392 e p.401; Comblin, 1999, p.148-9; Brighenti, 2001, p.17-19; Libânio, 2000, 2003, p.106-8, 2005, p.74-5; Queiruga, 2003). Em resumo, tomamos como caso de análise uma organização institucional Focolares, pretendendo visualizar as características do Movimento dos Focolares e, com esse, apontamos na direção dos novos movimentos religiosos leigos neofundamentalistas (tais como Movimento Comunhão e Libertação, Opus Dei, Movimento 
Neocatecumenato, Legionários de Cristo, entre outros). A transversalidade da análise às três instâncias justifica-se, portanto, pelas características comuns de instituições religiosas totais.

Verificaremos também se nossa análise do caso em questão pode contribuir para a discussão da hipótese que é nosso ponto de partida, ou seja, que nesse tipo de estabelecimento as modelagens da subjetividade têm características e efeitos particulares que, na literatura, são referidos ora de modo negativo, como rituais de mortificação do "eu" (Goffman, 1987; Benelli; Costa-Rosa, 2003a), ora de modo positivo, como produção de subjetividade serializada (Guattari; Rolnik,1986).

Ainda segundo essa hipótese, a instauração de tais processos subjetivos, que costuma dar-se pela supressão radical dos antigos modos de ser e sua substituição por modos novos, implica performances do tipo sintomático, isto é, há um retorno da história e da singularidade recalcadas sob a forma de sofrimentos diversos e de modos de ser estereotipados, dos quais a performance fanática é apenas o efeito mais destacado. Podemos indicar desde já um exemplo desse retorno do recalcado: nesse tipo de estabelecimento, o indivíduo se torna um formador e isso implica que ele terá de reproduzir, em futuros candidatos, os processos dos quais foi objeto. Nesse momento, pode surgir uma forma de retorno do recalcado de modo denegatório (Freud, s. d.(c)[1925]), justamente na forma de comportamentos e ditames radicalmente estereotipados.

Tudo se passa como se o indivíduo, agora na posição de formador, pudesse conjurar, mediante a repetição, na relação com seus formandos, os conflitos e angústias decorrentes do mesmo processo a que fora submetido e que em si mesmo permanecem não equacionados (Benelli; Costa-Rosa, 2002, 2003b).

\section{Dados relativos ao funcionamento institucional do noviciado focolarino}

A partir do relato de Urquhart (2002), vejamos o que é um jovem que vive no estabelecimento formativo do Movimento dos Focola- 
res. Trata-se de um indivíduo que se sente chamado a consagrar a sua vida a Deus, como leigo participante de um grupo eclesial específico, e que deve se preparar para assumir essa condição. $\mathrm{O}$ centro de formação do Movimento dos Focolares, localizado em Loppiano, na Itália, é o local onde essa preparação é efetuada. O candidato se transforma em habitante de um mundo especial e peculiar, onde não apenas recebe uma formação específica, mas também assume uma condição humana muito particular: a de um indivíduo internado.

Na sua condição de internado, mesmo voluntário, o novato dos Focolares partilha de condições similares, sob vários aspectos, às condições dos internados num hospital psiquiátrico, numa prisão ou num colégio interno. A dinâmica da vida institucional nesses estabelecimentos apresenta pontos de impressionante coincidência. Será necessário ressaltar oportunamente suas diferenças também. $\mathrm{O}$ próprio internato focolares pode ser visto como um colégio interno (Benelli, 2002, 2003a, 2003b), mas com objetivos mais específicos.

O Movimento dos Focolares tem uma escola que recebe novatos já iniciados e que aderiram ao grupo em Loppiano, perto de Florença, na Itália. Podemos dizer que ali os noviços (novatos) do movimento realizam seu noviciado (período preparatório à consagração religiosa, que culmina na emissão de votos religiosos e integração à determinada organização religiosa). Trata-se de uma aldeia modelo dos Focolares. Depois de dois anos ali, um novo membro permanente, devidamente preparado e qualificado, por meio de uma consagração religiosa ao assumir os votos de pobreza, castidade e obediência, pode ser enviado para qualquer parte do mundo para missionar e difundir o movimento. Essa experiência e a profissão dos três votos normalmente significam a inserção permanente do indivíduo no grupo religioso. Mas, no caso das instituições com características totalitárias esse processo de inserção parece estar longe de ser linear e pacífico.

A ideia de dedicar minha vida a Deus, trabalhando para Ele, me enchia de uma espécie de alegria e de sensação de aventura. Mas , eu finalmente tinha perdido meu senso de orientação e também o 
controle de minha vida. Não era capaz de compreender ou analisar o que acontecera comigo em Loppiano, e só muito mais tarde iria conseguir: eu era a própria aniquilação e absorção de uma personalidade individual pela instituição. Quando começou esse terrível e deliberado processo de destruição, eu me senti mergulhar inexoravelmente no período mais negro de toda a minha vida. (Urquhart, 2002, p.58)

\section{Processos institucionais de modelagem subjetiva}

O isolamento destaca-se como um elemento fundamental do processo formativo. Loppiano era utilizado para isolar totalmente os recrutas iniciados das influências do mundo exterior, para serem mais bem observados e modelados, de acordo com as crenças, ideias, normas, hábitos e comportamentos prescritos pelo movimento.

O isolamento era total. Nós estávamos a cerca de uma milha da civilização. A população local era constituída de velhos camponeses analfabetos. Durante os dois anos que ali passamos, não assistimos a um programa de televisão sequer, nunca deitamos os olhos sobre um jornal. Desse modo, não sabíamos praticamente nada do que estava acontecendo no mundo lá fora, e, após algum tempo, isso parecia não ter a menor importância [...]. Não havia livros, a não ser os escritos de Chiara Lubich e alguns outros sobre espiritualidade, publicados pela Città Nuova, a editora italiana do movimento. De qualquer modo, a leitura era desaprovada. Considerava-se estranho que alguém pudesse passar o tempo fazendo qualquer coisa sozinho, mas especialmente lendo. Durante todo o tempo que lá fiquei, li apenas dois livros. (ibidem, p.59)

Não havia rádio, televisão, música nem filmes "profanos", nem dias de folga ou sequer dinheiro para distrair ou contaminar os focolarinos em formação. Eram raras as saídas de Loppiano. O corte era radical para melhor efetivar o processo de ressocialização. Todos os anos havia a admissão de uns cinquenta homens e mu- 
lheres, que eram segregados, mantidos à distância uns dos outros. Esses futuros líderes do movimento vinham de todos os países do mundo. A grande maioria deles tinha apenas uma ideia muito vaga do que se podia esperar - Loppiano não tinha nenhum documento escrito sobre as atividades do movimento (ibidem).

$\mathrm{O}$ isolamento era para garantir que cada canto de nossas vidas estivesse sob completo controle de nossos superiores. Nossas mentes, atitudes e crenças tinham que ser radicalmente mudadas não através de um processo de aprendizado gradual ou do crescimento progressivo de uma convicção pessoal, mas através de um fluxo contínuo de uma torrente de conceitos e noções ao qual nós nos referíamos frequentemente, de brincadeira, como sendo uma verdadeira lavagem cerebral. (ibidem, p.60)

A tendência anti-intelectual (Libânio, 2003, p.106) do movimento se manifestava agressivamente em Loppiano. Candidatos de notória orientação ou formação intelectual eram sempre destinados para a realização de trabalho braçal e servil.

Mas o ataque à razão era levado a extremos: eles nos impunham uma condenação total do pensamento. "Vocês pensam demais", era a resposta que recebíamos quando fazíamos perguntas. "Não pensem!", diziam-nos duramente nossos líderes. "Parem de raciocinar." Ou, de maneira mais radical ainda: "Corte sua cabeça fora." Quando alguém levantava algum problema a respeito do gênero de vida ou das ideias com que eles nos bombardeavam, recebia logo como resposta que "era um ser fechado", "complicado", um "criador de problemas para si próprio" ou mesmo "vítima de algum complexo". O termo "mentalidade" era um dos motes, e aqueles que não estavam de acordo com o movimento eram acusados de ter uma mentalidade "velha". Eles nos aconselhavam a não tentar entender, mas a agir como eles mandavam, para "nos lançarmos para dentro da vida" em Loppiano, que a compreensão viria depois (sic). (Urquhart, 2002, p.61) 
Em Loppiano, o trabalho era exclusivamente manual. Os noviços trabalhavam em uma fábrica de caminhões ou em empresas menores que fabricavam tapetes e artesanato em madeira. Os noviços também tinham que participar de campanhas para vender de porta em porta a revista do movimento (Urquhart, 2002, p.64). Havia um controle exaustivo de todas as atividades e da rotina de cada um, caracterizando intenso processo de arregimentação (Goffman, 1987, p.44), que indica a obrigação de executar a atividade regulada em uníssono com grupos de outros recrutas e ainda um sistema de autoridade escalonada, no qual qualquer pessoa da equipe dirigente tem o direito de impor disciplina a qualquer dos novatos, o que aumenta claramente a possibilidade de sanção.

Todos os cantos e recantos de nossas vidas eram minuciosamente controlados para prevenir qualquer espécie de reflexão ou de vida pessoal e para garantir que nunca ficássemos sozinhos. Éramos divididos em grupos de seis a oito pessoas de nacionalidade mista (a língua comum era o italiano) alojados em pequenos chalés pré-fabricados ou nos alojamentos da fazenda convertidos em apartamentos. Os espaços onde passávamos a maior parte do tempo eram supercongestionados, impedindo assim qualquer tipo de privacidade, embora o "pudor" no momento de vestir-se e das abluções fosse observado com extremo rigor. (Urquhart, 2002, p.61)

Como podemos perceber, a tarefa da equipe dirigente do movimento é receber os novatos e aplicar-lhes uma série de procedimentos que visam seu controle e modelagem subjetiva. De acordo com Goffman (1987, p.24-39) podemos denominá-los de "processos de mortificação do eu”, que costumam ser padronizados e incluir os seguintes aspectos: enclaustramento/sequestração do indivíduo, processos de admissão que criam uma pasta pessoal que é continuamente alimentada com relatórios sobre o desempenho do internado, testes de obediência para conseguir a cooperação inicial do novato, despojamento dos bens, emprego e carreira, exposições contaminadoras físicas, sociais e psicológicas. E ainda, o "circuito" 
(ibidem, p.40-5) que interliga todas as esferas da vida do internado no contexto institucional, utilizando um comportamento qualquer como índice do estado geral da sua condição pessoal e o sistema de privilégios (ibidem, p.49-58), por meio do qual se manipulam arbitrariamente algumas necessidades e satisfações do indivíduo, utilizando-as como prêmios concedidos em troca de obediência.

Podemos notar como se reproduzem aqui as táticas dos novos movimentos religiosos neofundamentalistas. Adotam o princípio da eficácia de modo sofisticado. Utilizam técnicas da psicologia social, de massa e de marketing: elevam o grau de insatisfação e desgosto para com a própria imagem até levar o indivíduo a romper com o "homem velho" e a aderir ao "homem novo" proposto pelo grupo. Palestras devidamente preparadas para produzir esse efeito são realizadas diante de indivíduos deslocados de seu cotidiano, onde poderiam sentir segurança. Assistem, desprovidos de suas defesas habituais, à projeção de um quadro que retrata sua condição humana numa perspectiva demasiado negativa. Sua pequenez humana e moral é amplificada, de modo que o desejo de mudança brota quase que naturalmente. Então os indivíduos podem ingressar no grupo, aderindo à proposta apresentada, que já estava preparada anteriormente, com recursos e estruturas de apoio. A partir de técnicas comuns de recrutamento e formação de seus adeptos, esses grupos religiosos buscam com eficiência tornar o indivíduo totalmente dependente do movimento, passando a viver de sua doutrina: ele é despojado de sua autonomia e capacidade de reflexão e decisão pessoais.

Isso é algo que vivi de maneira muito intensa na experiência de "imersão total” em Loppiano. Assim como tínhamos que renunciar a todos os "apegos", de "perder" tudo, pessoas e coisas que nos fossem caras, também tínhamos de aprender a destruir nossos sentimentos. Sentimentos não têm a menor importância. Tínhamos que substituí-los pelos inúmeros preceitos que o movimento sugeria que aplicássemos obsessivamente no dia adia. Estes preceitos incluíam as exortações frequentes de Chiara para "destruir o ego", "morrer para nós mesmos" e para "aniquilar" a nós mesmos ou 
nos tornarmos absolutamente "nulos". Todo pensamento devia ser removido, bem como as emoções que até então havíamos experimentado. (Urquhart, 2002, p.75)

Vejamos outros efeitos da estadia de Urquhart em Loppiano.

Loppiano conseguiu isso com a maior eficiência, ao nos arrancar de nosso antigo mundo, criando um universo novo, totalmente irreal, de falsos valores. A sensação de desorientação que experimentei logo ao chegar era tão aguda que meus primeiros três meses ali foram um "branco" total. Um imenso vazio. Recordo aqueles meses ali mais exatamente como escuridão total. Eu tinha passado da atividade e das motivações da adolescência para uma juventude de monotonia, sem objetivo e sem sentido. O que me trouxe de volta foi a descoberta de que, para horror meu, eu passava o dia inteiro esperando a refeição seguinte. E não era porque a alimentação fosse frugal demais, não! Era simplesmente porque não havia absolutamente nada a esperar à frente. Minha ilimitada confiança anterior fora substituída por um estado de dúvida constante e uma sensação de que eu não tinha o menor valor. E isto não se aplicava apenas à dimensão espiritual; incluía também um colapso da fé em minha capacidade intelectual e prática (sic). (ibidem, p.75-6)

Essa seria a tecnologia de modelagem típica de instituições e estabelecimentos totalitários, instrumentos implementados para modificar e transformar as pessoas. Nesses rituais de mortificação do "eu" situa-se uma forma de modelagem subjetiva por subtração. Porém, observando mais cuidadosamente, pode-se perceber que, nessas instituições de formação religiosa, há uma ênfase nos processos de modelagem por acréscimo.

\section{O trato institucional do tema da sexualidade}

No Movimento dos Focolares há afirmação clara da tradicional superioridade do celibato e da virgindade sobre o casamento e a prática sexual (ibidem, p.249-71). Embora as reuniões públicas 
sejam sempre mistas, produzindo uma impressão de normalidade descontraída, a segregação de sexos predomina em todos os níveis do movimento. A liderança está nas mãos dos celibatários, embora haja também membros casados no movimento, mas com estatuto inferior (ibidem, p.261-4). A homossexualidade deve ser tratada e "curada" por psiquiatras do movimento (ibidem, p.264-71).

Os temas espinhosos de sexo e sexualidade nunca eram mencionados durante os dois anos de curso em Loppiano. Fiquei convencido de que era o único ali a ter excitações sexuais que serviam para agravar ainda mais a sensação de desgosto e alienação. Talvez estivéssemos todos no mesmo caso. [...] Para os focolarini, o celibato era uma espécie de miraculosa castração espiritual. Afinal de contas, nós não éramos seres de carne e sangue; nós éramos anjos. [...] O estágio preferido do desenvolvimento emocional [...] parecia ser a pré-adolescência. [...] Eles estimulavam o comportamento infantil [...]. Eles tinham medo da complexidade das emoções adultas, e as rejeitavam. Nesse estágio de desenvolvimento estacionário, o sexo não tem nenhum espaço e, por conseguinte, nunca precisa ser mencionado. (ibidem, p.254-5)

Nos processos de modelagem subjetiva por acréscimo, os ideais da organização institucional e do grupo parecem funcionar como fatores decisivos, pois fornecem os contornos de uma identificação do tipo massa-líder, em que ocorre a substituição de um arcabouço subjetivo singular por outro coletivo, de características altamente idealizadas (Freud, s. d.(a) [1921]). Parece ser em torno dessa idealização que se dá a abdicação voluntária dos antigos modos de ser e pensar, e sua substituição pelos novos.

Quanto às relações interpessoais, a técnica utilizada no Focolares era "dividir para reinar". Nas palestras oficiais, a orientação era para que se evitassem as "amizades particulares", de modo a manter à distância pessoas das quais se gostasse.

Uma prática destinada a evitar a formação de "laços" ou "apegos" era a de ficar constantemente "embaralhando" os grupos, 
inserindo neles "cartas" diferentes. Depois de ter passado alguns meses juntos, sem que ninguém nos prevenisse, uma noite, antes da sopa, a gente ouvia a leitura de uma lista que anunciava as novas configurações e tínhamos então que embalar todos os nossos pertences e fazer a mudança para novos grupos. Estas mudanças eram concebidas de tal maneira que ninguém iria ficar em companhia de um antigo colega de quarto. (Urquhart, 2002, p.61)

Mediante essa espécie de desterritorialização social e afetiva era possível evitar um fenômeno comum em instituições totais (Goffman, 1987, p.159): o processo de confraternização, no qual o grupo dos internados se une, desenvolvendo apoio mútuo e uma cumplicidade como resistência a um sistema que os forçou à intimidade numa única comunidade igualitária de destino. No claustro, a solidariedade costuma produzir uma infinidade de grupos primários no estabelecimento: "panelinhas", facções, inclusive ligações sexuais mais ou menos estáveis, chegando até a formação de pares, através dos quais dois internados podem passar a ser reconhecidos como "amigos" ou "casal" pelos demais companheiros (Benelli, 2003b).

A institucionalização da existência humana tende a torná-la insípida, pasteurizada, num processo de achatamento e uniformização de toda e qualquer singularidade. O indivíduo tem mecanismos de resistência que disparam para enfrentar os poderosos efeitos que a máquina kafkiana produz.

Os dilemas morais apareciam frequentemente com muita clareza quando eu acordava no meio da noite. Situações que pareciam confusas e tenebrosas durante o dia tornavam-se de repente claras como cristal. Quando eu acordava à noite em Loppiano, os pensamentos e as sensações que se apoderavam de mim eram sempre os mesmos: "Que diabos estou fazendo aqui?" Mas esta clareza iria desaparecer ao primeiro raio de sol da manhã seguinte, e eu voltaria para aquilo que considerava a realidade. Como tudo que anteriormente havia tido importância para mim tinha sido esva- 
ziado, só restava uma sensação esmagadora: nada tem importância! (Urquhart, 2002, p.75-6)

Nada mais tinha importância, exceto o próprio movimento. Não restando nada ao indivíduo, ele passa a ter uma existência vicária, vivendo apenas por meio de lutas, projetos e triunfos da organização. Perdendo sua existência singular, só lhe é permitida uma existência institucional, desprovida de singularidade. Os dados de Urquhart (2002) indicam que os membros do Movimento dos Focolares vivem um processo de repressão intensa de conflitos, contrariando importantes necessidades pessoais. Vivendo num estado de frustração crônica, podem ter sua saúde física e psíquica abaladas. A tentativa de supressão da singularidade subjetiva, do desejo, da sexualidade e das emoções pode falhar e conflitos inconscientes mantidos silenciosos, a duras penas, podem eclodir, manifestando-se por meio de sintomas como ansiedade, depressão ou excitação motora excessiva. Efeitos típicos da institucionalização da vida humana costumam ser sintomas de tensão extrema, de estresse, medo e culpa. Urquhart (2002) descreve vários exemplos de tais efeitos.

Evitar a formação de "laços" ou apegos era, portanto, aparentemente, uma forma da organização e seus dirigentes se defenderem de possíveis ações, por parte dos internos, de contraposição ao instituído. Outro elemento que facilitava bloquear a confraternização entre os recrutas "noviços" era a ênfase dada à mudança constante e à incerteza.

O horário diário ou semanal era alterado constantemente. Frequentemente planos eram mudados em cima da hora. De tempos em tempos, tínhamos de deixar o jantar no meio para atender a uma convocação para uma reunião no salão principal. (Urquhart, 2002, p.62)

Essa arbitrariedade e imprevisibilidade permanentes, que resultavam em constante desorientação ambiental, eram suficientes para sabotar as diversas estratégias de ajustamento secundário 
(Goffman, 1987, p.159ss.) de que o grupo dos noviços poderia lançar mão no estabelecimento para se defender da desterritorialização social e subjetiva a que era submetido.

Nesse ponto, parece oportuno agregarmos algumas observações de Pereira (2004, p.283), que sublinha essa característica importante das instituições totais: o temor paranoico do retorno, contra o estabelecimento e a equipe dirigente, das pulsações instituintes recalcadas no conjunto dos internos pelo próprio processo formativo, dada sua natureza.

As grandes instituições e organizações geralmente temem a união dos irmãos, dos participantes dos grupos, percebendo-os como uma força que pode voltar contra elas. A fantasia inconsciente institucional é a de que a união dos participantes do grupo pode destruir o instituído. Isso é frequente em instituições totais e constituídas de autoridades déspotas e verticais. Assim, as relações fraternas grupais tornam-se concorrentes dessas fantasias institucionais, autoritárias e centralizadoras. Nas organizações geridas pelo autoritarismo é impossível o trabalho de escuta e de diálogo.

\section{A rotina como estratégia de modelagem subjetiva}

Vejamos outros dados sobre a rotina diária em Loppiano, de acordo com Urquhart (2002, p.62), ainda ilustrativos do funcionamento das instituições totais e de seus efeitos de modelagem subjetiva.

Geralmente o despertar era às 6 horas e $30 \mathrm{~min}$. ou às 7 horas. As atividades do dia começavam às 7 horas e $30 \mathrm{~min}$. com uma meditação, que sempre consistia em uma "experiência de grupo" comentada por um líder. Ele lia o evangelho da missa do dia e fazia um breve comentário. Dos cem ou mais presentes - o primeiro e o segundo ano do curso - ele escolhia aleatoriamente aqueles que iriam participar de uma "experiência" inspirada na leitura. Esta era 
uma situação controlada, na qual a coparticipação na "experiência" podia ser corrigida e as nossas vidas passadas redefinidas em termos da doutrina do movimento, conhecido método de reforma do pensamento. [...] $\mathrm{O}$ medo de ser criticado nessas reuniões fazia parte daquele sentimento de ansiedade criado em Loppiano das mais diversas formas. Depois da meditação, havia meia hora para o café da manhã e, logo depois, trabalho de 8 horas e 30 min. até 13 horas. Havia então o tradicional almoço italiano que durava até 15 horas, e, depois novamente, trabalho até 19 h30 ou 20 horas, que era hora da missa. Depois da missa tínhamos o jantar, e frequentemente havia novamente reunião no salão principal, de 21 até meia-noite ou mais tarde. Muito ocasionalmente havia um show em que nós mesmos nos apresentávamos ou alguma sessão de cinema. [...] Nós trabalhávamos aos sábados pela manhã e à tarde ficávamos livres para a limpeza da casa ou para as atividades de grupo em nossas pequenas comunidades (mas não para ir à cidade, o que seria realmente impensável). (Urquhart, 2002, p.62-3)

Outras estratégias do Focolares, segundo Urquhart: para cumprir eficientemente sua tarefa, o movimento sistematiza, por meio de palestras redigidas previamente, um conteúdo simples, claro e compacto que deveria ser transmitido, difundido e inculcado em todas as instituições do movimento. Com o objetivo de dar ao curso realizado em Loppiano, durante dois anos, um certo status legal para a hierarquia eclesiástica, também havia aulas, que eram ministradas duas manhãs por semana. Havia professores focolarinos formados em Bíblia, História da Salvação e inclusive em Filosofia e Teologia:

Embora esses professores fossem realmente bons e bem preparados, eram pouco considerados pelos estudantes, que os tinham em conta de "intelectuais" e, por causa disso, eram desprezados. Muitos estudantes, frequentemente os favoritos das autoridades, dormiam abertamente durante as aulas. Esta atitude era tacitamente aprovada por nossos superiores. No final do ano éramos 
submetidos a exames orais ridiculamente simples, exames para os quais ninguém estudava e, apesar disso, todo mundo passava. (ibidem, p.63)

É possível perceber que o processo formativo dá pouco ou nenhum destaque para a dimensão intelectual. A persuasão ali não parece passar pelo aspecto racional, que é desligado tanto quanto possível. Parece ser a tecnologia microfísica (Foucault, 1999b) que atua na aldeia de Loppiano. Ao atentarmos para as práticas institucionais que ali são implementadas, podemos verificar toda uma "arte das relações de poder" (Foucault, 1999b, p.245) que é aprendida ao mesmo tempo em que se é submetido a ela, sem maiores teorizações. $\mathrm{O}$ corpo mesmo parece ser o objeto da formação/conversão/modelagem ao formato do movimento. Seria esse um modo mais fácil de garantir que o tratamento recebido pelos noviços focolarinos fosse fidedignamente transmitido aos futuros adeptos do movimento?

Loppiano também funcionava como uma vitrine do movimento e recebia centenas de visitantes todos os domingos. Aí os noviços tinham que trabalhar de modo extenuante para receber, alimentar, entreter e festejar os visitantes, de maneira que saíssem dali "convertidos".

A primeira tarefa das manhãs de domingo, depois da meditação, era a leitura em voz alta das tarefas do dia. Alguns de nós ficavam encarregados de supervisionar a circulação de veículos; outros iam ajudar nas cozinhas; os membros da turma de residentes e aqueles que eram conhecidos por terem boas "experiências" para contar seriam encarregados do show. A tarefa que mais nos apavorava era a de acompanhar os grupos. Éramos escalados para entrar em contato com um determinado carro e passar o dia inteiro com os ocupantes. Por mais exaustos e deprimidos que nos sentíssemos, era nosso dever nos misturar a eles, estabelecendo contatos pessoais com todos eles, e de, à custa de muita alegria e delicadeza, convencê-los de que aquilo era a Utopia. (ibidem, p.64) 
Todos os noviços tinham que se mostrar prestativos e diligentes, numa animação artificial, apresentando um vasto espetáculo que transformava Loppiano, por um dia, em uma espécie de "Disneylândia Espiritual”. Trata-se aí de uma muito bem desempenhada apresentação institucional, devidamente mapeada por Goffman (1987, p.90-4).

O relato sobre a experiência no Focolares nos apresenta, ainda, outros aspectos do funcionamento institucional em que se destacam de forma clara os procedimentos de modelagem subjetiva por acréscimo. Não parece estranho, diz o autor, que esse microcosmo institucional totalitário acabe produzindo seus próprios códigos de conduta, a partir de uma escala de valores original para medir o desempenho dos noviços em preparação. Além do culto à personalidade de Chiara Lubich, em Loppiano também havia o culto ao líder local da comunidade, sempre cercado de jovens que voejam em torno dele, uma "corte de favoritos" esperando para "colher as pérolas de sua sabedoria".

Havia focolarini que se escondiam no guarda-roupa do líder, ou debaixo da sua cama, e que se levantavam de repente no meio da noite para obter um favor. Outros ficavam rondando dias e dias em torno da sua antecâmara, fora do seu escritório, um lugar lendário para nós: eles pediam uma entrevista, ou, outras vezes, simplesmente ficavam olhando para ele com expressão de cachorro submisso quando ele entrava ou saía. Ele mesmo alimentava a crença insidiosa de que, se você estivesse "em unidade", ele notaria sua presença, do contrário, ele não o veria. Este era outro mito que criava tensões artificiais e ansiedades em nós. Como acontece com muitos dos mistérios fictícios criados dentro dos novos movimentos, é impossível saber o que fazer para ser visto e para ter sua presença "notada". (Urquhart, 2002, p.64ss.)

É evidente como certos rituais de tiranização subjetiva dos internos parece funcionar de modo a implementar e reforçar anseios narcísicos do tipo "culto das personalidades" (Lasch, 1983), fator 
que tende a propiciar a submissão cega aos ditames do superior/ mestre.

Outro aspecto das práticas institucionais empreendidas nesse contexto, com o mesmo fim, consiste na submissão do internado a um outro detentor de um poder absoluto. A responsabilidade principal do líder/formador é verificar e atestar a autêntica vocação dos noviços-candidatos, selecionando, por meio da observação, os indivíduos considerados aptos para pertencerem ao grupo e dispensando os outros.

Aparentemente considera-se que a autêntica vocação se manifesta em sinais, motivações válidas para a admissão. $\mathrm{O}$ discernimento vocacional realizado pelos dirigentes parece baseado, sobretudo, na observação dos comportamentos. Como nas instituições totais, o candidato é enclausurado para melhor ser observado, como um objeto expropriado de sua singularidade, que, quando emerge, tende a ser tomada como perturbação. A vocação pode ser considerada como portadora de uma essência passível de verificação fenomenológica, isso resultava em uma situação em que o futuro do internado era decidido unilateralmente pelos dirigentes a partir de pretensos dados objetivos (Urquhart, 2002).

\section{Estilo de liderança da equipe de formadores no noviciado focolarino}

No relato desse autor há, ainda, outro aspecto do processo de modelagem subjetiva que merece ser sublinhado: os líderes, "canais da unidade", exigiam dos noviços um esvaziamento total, uma aniquilação completa da vontade, para estarem em "unidade" com eles e com o Movimento dos Focolares.

No interior desse mundo irreal, com suas angústias artificiais, nossas faculdades mentais e nosso senso crítico diminuíam. Ao mesmo tempo, a demanda por uma obediência total e irracional crescia. [...] Diante de nosso superior, nós temos que ficar vazios, que sermos nada, uma simples criatura sem a menor capacidade 
de questionamento: temos que aceitar qualquer capricho dele. [...] A "unidade" requerida não é apenas a obediência cega no plano externo, é também um assentimento da mente, chamado de "unidade da mente" ou "unidade do pensamento". "Unidade" não era absolutamente o conceito igualitário que eu imaginara, mas uma reinvenção da autoridade absoluta e da hierarquia rígida. (Urquhart, 2002, p.66)

Esse conceito de unidade e de comunidade pregado pelo movimento Focolares parece não deixar espaço algum para uma vida autônoma nem para pesquisas pessoais. Não é preciso buscar nada quando todas as respostas já foram dadas pelo grupo. A única coisa a fazer é interiorizar e ruminar constantemente os ensinamentos do mestre do movimento. A submissão total ao líder local unia o noviço automaticamente ao fundador do grupo. Parece inevitável vermos aí um rito de modelagem subjetiva de caráter radical. A "Unidade" em questão não se refere ao Um da singularidade, que se conta como mais um, mas ao Um da unificação, que supõe o apagar-se em benefício do outro, líder ou grupo, que culmina num tipo de identificação global que está na base da submissão massa-líder proposta por Freud (s. d. (a)[1921], s. d.(c)[1925]), a que já nos referimos anteriormente, e da qual aparece como corolário necessário, a atitude fanática.

Tal característica das instituições totais e de suas consequências também já havia sido identificada por Goffman (1987, p.59-63): nelas os indivíduos tendem a adotar comportamentos altamente obsequiosos para com a autoridade. São as estratégias adaptativas nomeadas como "colonização", na qual o indivíduo tende a adotar a vida no estabelecimento como se fosse a de seu lar e como "conversão", tática em que o internado procura aceitar a interpretação oficial da equipe dirigente, buscando representar o papel do internado perfeito, disciplinado, moralista, sempre à disposição da autoridade.

Nessas circunstâncias, o colonizado tende a tornar-se o agente mais feroz da colonização. A propósito, Urquhart também nos fala 
sobre sua percepção da equipe formadora, afirmando que seu trabalho "formativo" era executado com convicção, apesar dos altos custos emocionais e com grande desgaste pessoal para os membros da equipe dirigente.

Esta teoria da unidade era particularmente apavorante em Loppiano, porque muitas das pessoas que ali tinham autoridade haviam sido mandadas para lá porque tinham problemas; eu agora sei que muitas delas sofriam de estresse ou de depressão profunda - talvez outras tivessem apenas dificuldades com o próprio movimento. Para eles, Loppiano era uma espécie de prisão aberta onde seus problemas podiam ser controlados. É claro que alguns deles apresentavam comportamentos muito estranhos. (Urquhart, 2002, p.67)

Afirma ainda que era angustiante ficarem submetidos à autoridade absoluta do líder, que podia ser uma pessoa problemática e arbitrária, mas "a ideia de apresentar queixa a uma autoridade superior era totalmente inadmissível no quadro de referências dos Focolares" (ibidem, p.67). Psicologização ou sociologização das contradições sociais e das conflitivas relações de poder existentes no estabelecimento parecem ser mais um dos modos de lidar com possíveis formas de contestação ou resistência.

Éramos submetidos a uma chantagem espiritual que era a seguinte: se tivéssemos problemas, os únicos culpados éramos nós mesmos. Mas, além disso, havia uma pressão muito maior, que podia ser formulada assim: por mais infelizes que nos sentíssemos, não havia nenhum meio de escapar. Era impossível sair dali. Como trabalhávamos simplesmente para garantir nossa manutenção, não tínhamos acesso ao dinheiro. Muitos de nós vinham de outros continentes, ficando assim inteiramente à mercê do movimento. Nossas forças de resistência estavam tão enfraquecidas que, se quiséssemos sair dali, a simples perspectiva de ter de persuadir nossos 
superiores a nos deixar ir embora já era aterradora demais. [...] Mas isso significaria uma ruptura total com o movimento e, naquele contexto, era impossível imaginar a vida fora de sua influência. Não havia, por conseguinte, nenhuma alternativa real: o caminho era a rendição total. (ibidem, p.67-8)

\section{O Movimento dos Focolares como caso exemplar dos novos movimentos religiosos}

A partir das conclusões possíveis de nossa análise do Focolares, poderíamos perguntar até que ponto ele não pode ser considerado expressão das características dos novos movimentos religiosos leigos neofundamentalistas, na medida em que, como esses, ele comumente utiliza uma pedagogia eminentemente tradicional, caracterizada pela ênfase na transmissão autoritária de conhecimentos do mestre para o discípulo. O mestre/líder ocupa o centro da atividade pedagógica/formativa. O relacionamento entre o mestre e o aprendiz é marcado pelo autoritarismo do primeiro, detentor do saber, da competência e do poder. O bom discípulo é aquele que assimila totalmente o conteúdo e adota os comportamentos, ideias, crenças, valores e discursos prescritos. Autoritarismo social, disciplina rígida, ordem e submissão, imposição de ideias e conceitos, valorização da hierarquia e da tradição parecem caracterizar esses grupos, além dos outros rituais comuns às instituições totais.

Sua técnica predominante é a da inculcação autocrática, visando à fixação da doutrina do líder fundador. Sua pedagogia é tradicional, enfatizando a obediência à autoridade e não estimulando o senso crítico nem a criatividade. Aristocrática, essa tendência pedagógica se pauta por valores e práticas autoritárias, visando à adaptação do indivíduo à sociedade, num processo de reprodução das relações sociais hegemônicas de dominação-subordinação. Não há acompanhamento pessoal com base num diálogo entre iguais, conforme o preconizado nas práticas pedagógicas dialéticas baseadas na persuasão, no consenso, e realizadas a partir da produção co- 
letiva e da criação comunitária. A máquina funciona por si mesma: sua tecnologia produz efeitos automaticamente, basta estar inserido e encerrado nela. Viver no estabelecimento é formativo por si só, dados seus mecanismos rigidamente instituídos, sua manipulação dos temores individuais e seus efeitos microfísicos.

Apesar dessa prática pedagógica autoritária, o discurso institucional tende a responsabilizar o indivíduo pelo seu sucesso ou fracasso no processo formativo, aproximando-se da pedagogia renovada, baseada no pensamento liberal, que coloca a ênfase no desenvolvimento da personalidade do aprendiz. Inversamente ao modelo das pedagogias dialéticas, o discípulo, e não o coletivo, torna-se o centro da prática pedagógica. Nesse contexto o processo de psicologização do sujeito pode ser entendido como uma estratégia mistificadora que se superpõe às relações de poder, ocultando-as por meio de um discurso lacunar e deslocando-as para a interioridade individual: parece clara uma particularização de fenômenos que são originalmente, sobretudo, de ordem social e coletiva.

\section{Análise dos efeitos éticos da tecnologia totalitária de produção de subjetividade}

Qual é o efeito de uma experiência como essa em termos éticos? Que tipo de sujeito se produz a partir dos operadores institucionais utilizados pelos movimentos religiosos (Galindo, 1994; Martelli, 1995; Urquhart, 2002; Lubich, 2003; Ferreira; Lauand; Silva, 2005) que estamos estudando? Quais são seus efeitos em termos de produção de subjetividade?

Operando basicamente por subtração (da liberdade, do tempo, da autonomia, da capacidade de reflexão, de escolha e de decisão, eliminando comportamentos indesejáveis e instaurando novos mais adequados etc.), e por meio da identificação baseada tanto no "eu" quanto nos ideais, mas, sobretudo, por meio de acréscimos de imaginário (doutrina do movimento, ideias, crenças, conceitos, representações, modos de se ver e olhar para a realidade etc.), a tecnologia empregada em Loppiano pode produzir uma subjetividade 
serializada de matiz fortemente fanático. Não há espaço para a individualidade, para a iniciativa criadora, para a singularidade. Como o psiquismo pode reagir a essa modelagem institucional? Isso tem efeito permanente? Será que essa "criatura institucionalizada" pode se desconfigurar e buscar rumos diferentes e divergentes da programação imposta?

A resposta a tais questões, fundamentais para pesarmos certos impasses da subjetividade contemporânea, só pode ser ensaiada a partir de dados mais amplos do que os que temos no momento. Porém, ao menos um aspecto parece evidente: há indivíduos que suportam e se adaptam a essa modelagem, e tão bem, que são eles que reproduzem e, portanto, perpetuam a organização; mas há outros que essa conjuntura coloca em situação agonística. No caso dos últimos, não sendo dadas na estrutura institucional quaisquer outras possibilidades alternativas, só lhes resta a saída da organização. É o caso do sujeito de cuja experiência se ocupa nossa análise.

\section{O processo de entrada e permanência no movimento Focolares}

Se, conforme acabamos de constatar, estamos diante de uma tendência eclesial de viés fundamentalista radical que se mostra contrária ao valor do diálogo, da participação, da deliberação coletiva em busca de consenso; rejeita toda forma democrática de poder e gerenciamento político; tende a manipular predominantemente a dimensão emocional dos indivíduos e grupos em busca de restaurar um passado mítico; então como explicar que alguém deseje entrar para um movimento tão altamente fanatizante e permanecer nele? As possíveis razões da entrada e da permanência podem ser analisadas a partir do mesmo conjunto de dados. Encontramos em Libânio (1984, p.127) uma primeira tentativa de explicação.

Outra força e recurso dessa posição tradicionalista consiste em apresentar diante dos problemas teóricos e práticos respostas simples, lapidares, firmes, assim questões complexas são simplificadas 
ao extremo, dando ao fiel a tranquilidade de ter resolvido e de possuir, portanto, solução clara e distinta. [...] Em momentos de crise e perplexidade, em que vivemos, tal posição desperta certo fascínio sobretudo sobre personalidades angustiadas, inseguras. Traz alívio, pelo menos momentâneo, para a angústia da dúvida e do questionamento. Frequentemente as soluções não passam de evasão, de ilusão, por desconhecerem a gravidade e complexidade da problemática. Quem sabe que parte de sucesso entre setores jovens de posições tão radicais conservadoras tenha a ver com uma etapa da evolução de certas personalidades inseguras, de horizonte ainda curto intelectualmente, em momentos de crise, de perplexidade, de dúvida? Assim as psicologias frágeis deixam-se atrair por posições claras, firmes, simplistas. Por outro lado, no meio dos tradicionalistas surgem personalidades fortes de liderança que arrastam após si pessoas mais vulneráveis psiquicamente.

Segundo Libânio, o momento histórico posterior ao Concílio Vaticano II mergulhou os católicos numa certa anomia, tal a constância e velocidade das transformações. Isso teria suscitado um desejo de ordenamento, de pontos de referência que dessem segurança. Libânio (1984, p.157) considera que situações de crise institucional são propícias para a emergência de posturas submissas e autoritárias, nas quais um mesmo indivíduo pode assumir atitudes de "senhor" ou de "súdito", conforme a conveniência:

Mais facilmente, nestes momentos as psicologias fracas, abaladas em sua segurança, desejam neuroticamente um apoio. E como reflexo do caráter oposto, outras personalidades se sentem provocadas em seu instinto autoritário. Na sua estrutura profunda, seja o impulso de buscar apoio em outro, de submeter-se como o de autoritarismo, são semelhantes. Ambos revelam uma fuga à liberdade e à individualidade, estabelecendo uma relação de dependência simbiótica com um outro objeto. No caso, o autoritário se identifica com o poder. $\mathrm{O}$ submisso foge à liberdade e à individualidade. Os dois polos se casam bem, alimentando-se mutuamente. 
Quanto aos motivos da permanência, Urquhart (2002, p.416) explica seu caso, depois de nove anos de pertença ao Movimento dos Focolares.

Os anos que passei no Focolare foram provavelmente os mais infelizes e os mais improdutivos de toda minha vida. Mas eles nos ensinavam que o sofrimento é essencial para o nosso estilo de vida; "Jesus abandonado" era a chave para a unidade, por isso nós tínhamos que sofrer. Esta foi a razão pela qual tive de suportar um estado de tormenta interior durante tantos anos. A minha decisão de sair do movimento não foi uma decisão pensada e consciente. A "Santa Jornada" do Focolare é uma jornada não de autodescoberta, mas de autodestruição e esquecimento de si próprio. Como ficamos alienados de nossas próprias emoções deliberadamente suprimidas, qualquer decisão pessoal é simplesmente impossível. Além disso, todas as escolhas para os indivíduos são feitas pela comunidade "em unidade".

Vemos que, de certa forma, ele acrescenta outros fatores institucionais aos do indivíduo. As razões da ordem estão na reafirmação da própria posição do indivíduo como sofredor a serviço de algo maior, além dos efeitos do processo de institucionalização que chamamos rituais de mortificação do "eu" e de colonização subjetiva, que deixam os indivíduos sem capacidade de tomar decisões de caráter pessoal.

Além de Libânio (1984), outros pensadores têm formulado ideias na tentativa de responder a essa questão. Merecem destaque as considerações de Freud (s. d.(a)[1921], s. d.(b)[1927] e s. d.(c)[1932]), as de Lasch (1983) e as de Lindholm (1993). Em "O problema da Concepção Unitária do Universo”, Freud (s. d.(c) [1932]) analisa o que considera uma característica da vida psíquica humana: a exigência de resolução unitária de todos o problemas de nosso ser; essa tendência à totalização teria um caráter afetivo e, ao mesmo tempo, frágil, por ser resultante da dificuldade de lidar com o desamparo, a incompletude e a indeterminação das situações da 
vida concreta. Em "Psicologia das massas e análise do eu", Freud (s. d.(a)[1921]), ao estudar os grupos do tipo massa, caracteriza-os como uma estrutura particular em que o líder assume na subjetividade dos indivíduos a função muito mais de um objeto ideal de consistência narcísica e imaginária, do que de um suporte capaz de permitir ao indivíduo orientar-se na direção dos ideais da cultura. Tratar-se-ia de conjunturas nas quais, para os indivíduos, não estaria sendo possível marcar a distância entre o ego atual e o ego ideal. Nesses casos, o líder como ego ideal seria requisitado para fazer as vezes do objeto de identificação, o que tende a implicar em identificações maciças do "eu" com o outro. Finalmente, em "O futuro de uma ilusão”, Freud (s. d.(b)[1927]) assinala que os homens podem responder diferentemente aos enigmas ante os quais se choca o desejo de saber e a tolerância ao desamparo. Alguns exigem respostas de teor absoluto e totalitário; outros toleram mais a dúvida e a indeterminação. Parece acenar com uma tentativa de diferenciar dois modos da consistência subjetiva, definidos segundo a consistência mais imaginária ou mais simbólica dessa relação do homem com o mundo, que determina suas formas de resposta aos enigmas com que esse o interpela. Esses argumentos freudianos vão claramente na direção de indicar possíveis fatores da entrada e da permanência dos indivíduos nessas instituições.

Lasch (1983) foi um dos primeiros pesquisadores a abordar uma série de inflexões na subjetividade, partindo da hipótese de que transformações na sociedade contemporânea podem incidir na subjetividade dos indivíduos de modo a influenciar as modalidades das relações objetais. Propôs o conceito de "Cultura do Narcisismo" para designar o caráter regressivo dessas transformações. Em uma de suas teses principais afirma que a maneira como estão organizadas as relações sociais no modo de produção capitalista das sociedades de capitalismo desenvolvido, das quais a sociedade americana seria um dos protótipos, enfraquece de tal modo as relações dos indivíduos com o campo do simbólico que se chega à constituição de egos enfraquecidos, propensos à busca de experiências de êxtase e aos vínculos carismáticos. 
Finalmente, Lindholm (1993) agrupa uma série bastante ampla de fenômenos sob o título de carisma. Considerando a mesma conjuntura geral de desamparo material e subjetivo, que está na base da "Cultura do Narcisismo", pensa que nessas circunstâncias alguns indivíduos tenderão a procurar outros com quem possam se identificar buscando experimentar uma poderosa sensação de perda dos limites do "eu", se esta não oferecer perigo de total desintegração. Tomando o outro como apêndice constitutivo da própria unidade do 'eu', estabelecem com ele relações de extrema dependência, ao mesmo tempo em que experimentam sensações de absoluta completude (sentimento oceânico). Para esses indivíduos, o outro em questão seria sempre um representante direto do primeiro objeto da fase do desenvolvimento da personalidade correspondente ao narcisismo, em que se sobressai a exigência de completude. Eles se encontrariam num impasse quanto ao engajamento pleno no simbólico, que lhes propiciaria um tipo de completude pela via dos Ideais, passível de permitir uma relação com a transcendência fora das vias do tipo fanático. Para esse autor, tais personalidades também têm seu aparecimento em conjunturas em que os padrões externos estão corroídos e as figuras de autoridade são consideradas ilegítimas. É aqui que os líderes carismáticos se apresentam como possibilidade de "superegos substitutos", que podem, e estão autorizados a, externalizar a agressão. "Quando a autocracia interna do superego desaparece, ela renasce externamente [...] torna-se o poder coercitivo do sacerdote, do príncipe, do feiticeiro e do grupo" (Lindholm, 1993, p.105).

Podemos perceber que o conjunto de explicações levantado nos diferentes autores está muito mais interessado em responder às questões sobre possíveis fatores da entrada e permanência, enfatizando o lado dos liderados. E quanto aos líderes? Libânio (1984) fala em personalidades frágeis e fortes, entretanto o conceito de personalidade forte é bastante problemático, uma vez que parece, tanto o líder quanto os liderados, tratar-se de indivíduos que têm demandas da mesma natureza.

Trata-se nos dois casos da mesma forma de identificação, embora uns o façam utilizando o poder e outros o sofram como objeto 
de dominação. O que parece mais difícil de compreender são os possíveis fatores dessa identificação diferencial. Ensaiamos uma pequena explicação. Há uma diferença básica naqueles que ocupam o lugar de líder: a liberação de um componente perverso da personalidade permitindo que eles gozem por bancarem o grande Outro para o outro; sua vivência de completude poderia vir então dessa identificação direta com Deus. Vale a pena esclarecer que dizemos liberação porque é necessário considerar a possibilidade do gozo perverso como acessível à conjuntura psíquica definida como personalidades narcísicas, se não, como explicar que, dependendo das circunstâncias, o indivíduo possa passar de liderado a líder? Por outro lado, é importante esclarecer que não se trata necessariamente de subjetividades "perversas" (formadas por renegação do significante do Nome do Pai (Dor, 1991, p.93-105), em que a função pai estaria renegada. Trata-se de subjetividades "neuróticas”, nas quais a função pai está admitida (por recalcamento), só que por meio de uma identificação massiva, portanto, de modo diferente daquele da construção de uma identidade (conforme definição anteriormente proposta para identificação e identidade).

\section{A crise e o processo de desligamento do Focolares}

E quanto às possíveis razões da saída: por que o indivíduo deixaria o grupo ou movimento religioso fundamentalista no qual ingressou? Uma primeira explicação poderia residir em que tais grupos, dada a sua consistência e funcionamento, tendem a se recusar ao diálogo com a modernidade, conduzindo seus participantes a se fixarem na postura fideísta ingênua em que estão ancorados (Brighenti, 2001, p.20). Ou seja, "escolhem-se os atalhos do coração, do testemunho, da vivência, do emocional para chegar à Revelação, saltando a longa caminhada da razão, com medo de perderem-se nos labirintos da crítica" (Libânio, 1984, p.152).

Quanto a essa questão, vale a pena analisar alguns elementos do percurso de Urquhart (2002): terminado o período preparatório em Loppiano, foi enviado para Liverpool, para abrir uma nova co- 
munidade masculina. Foi trabalhar como professor e essa inserção "no mundo" foi aos poucos lhe dando conta das transformações da realidade social da qual esteve alijado pelo movimento. Havia um vácuo em seus conhecimentos quanto a filmes, livros, teatro para preencher. Ele começou a desenvolver um trabalho com encenações teatrais, dando início a uma fase de iniciativa, criatividade e independência que não eram bem vistas pelo grupo. Mas havia também um segredo permanentemente atormentador: sua orientação homossexual.

Desde os meus 12 anos, mais ou menos, eu tinha consciência de que sentia uma certa atração pelos outros garotos de minha idade, ou mais velhos. Nas escolas católicas não se falava desse assunto naquela época, talvez nem mesmo hoje, e desta maneira eu me informava da melhor maneira possível, folheando livros de Freud nas bibliotecas. Durante muitos anos, mesmo depois de ter saído do movimento, considerei essas "tendências homossexuais" como tentação ou vício, muito mais do que como parte de minha própria estrutura psicológica. Quando terminou minha adolescência, comecei a tomar consciência de que aquilo não era simplesmente uma "fase" que passaria com o tempo, mas meu catolicismo sincero me forneceu meios de engavetar o problema e tratei de sublimar totalmente todos os impulsos sexuais. Quando descobri o Focolare eu já tinha ficado virtualmente assexuado aos 17 anos de idade. (Urquhart, 2002, p.418)

Sem dúvida, no caso de Urquhart (2002), a perspectiva do celibato podia soar bastante atraente por permitir protelar indefinidamente qualquer espécie de opção sexual, adiando para sempre qualquer experiência concreta, mesmo tendo uma consciência permanente de sua orientação específica. A tensão entre seus desejos eróticos (socialmente desaprovados e condenados pela religião) e a doutrinação constante quanto à pureza absoluta do "ideal" Focolares (um projeto de vida institucional altamente promissor) foi resolvida temporariamente em favor da segunda alternativa. Pode- 
-se dizer que o movimento Focolares lhe economizava uma neurose pessoal, oferecendo-lhe uma possibilidade de repressão segura e significativa.

Conforme o tempo passava e seu envolvimento institucional com o Focolares aumentava, também aumentava sua necessidade de confessar seu segredo aos superiores: não esconder nada deles significava estar "em unidade", já que os líderes eram o "foco da unidade". Esse impulso de autorrevelação conflitava com o temor da expulsão do movimento e a consequente impossibilidade de tornar-se um focolarino com seus votos e pertença permanente ao grupo. Depois de muita incerteza e hesitação, Urquhart (2002, p.418) confiou sua história ao seu superior:

Sua reação foi para mim uma surpresa. Meus sentimentos não tinham nada de errado em si mesmos, enquanto eu não fizesse nada. [...] O único conselho que recebi foi a resposta mágica do Focolare para todos os problemas - "amar a Jesus abandonado". Isto significava que no meu caso - como, estou certo disto, em muitos outros - o ponto fundamental nunca era enfrentado. "Jesus abandonado" era uma espécie de tapete cósmico para debaixo do qual eram jogados todos os assuntos desagradáveis e mais dolorosos. Este conceito encorajava a "cultura do segredo" do Focolare. Nós éramos proibidos até mesmo de falar sobre nossas dúvidas e dificuldades com os amigos dentro do movimento. Não devíamos compartilhar com os outros nossas "misérias". De acordo com a mentalidade do Focolare, um problema compartilhado era um problema dobrado.

Na temporada em Loppiano, depois de esforços heroicos, ele conseguiu se dominar: "Graças a uma imensa força de vontade consegui finalmente dominar minha batalha interior e ceder à euforia geral" (ibidem, p.420). Já durante o segundo ano em Liverpool, ele passou por uma experiência de ruptura radical na qual o reprimido irrompeu de modo violento e irracional, numa autêntica microcrise psicológica: uma atuação de caráter tipicamente homossexual. 
Numa reação desesperada aos anos de esforços para esquecer e reprimir, eu me vi no cenário de Morte em Veneza, sem jamais ter ouvido falar nem do filme de Visconti nem do romance de Mann. Num impulso eu faltei ao colégio e fiquei procurando um misterioso estranho escolhido ao acaso ao redor do centro de Liverpool. Quando caiu o crepúsculo, eu recuperei abruptamente os sentidos, como se estivesse acordando de um sonho. Não consegui achar nenhuma explicação para meu comportamento e tive medo de estar perdendo a razão. [...] O que este incidente indicava sem dúvida era uma crise pessoal profunda que devia ser resolvida. (ibidem, p.421)

Esses abalos iniciais foram se aprofundando. Contudo, Urquhart foi estimulado a fazer os votos de castidade, pobreza e obediência. Ele foi transferido para Londres e teve que deixar um trabalho muito gratificante em Liverpool. Tornou-se editor da Revista New City e rompeu com a proibição do movimento de ler jornais e revistas (ibidem, p.423). Descobriu que a homossexualidade havia deixado de ser um crime, passando a ser tema corrente e inclusive tratado de modo positivo por diversas publicações. Essas novas influências precipitaram a eclosão de uma crise pessoal intensa.

Comecei a sofrer seriamente de insônia, problema que nunca experimentara em toda minha vida. Esperava que isso passasse, mas a insônia continuou por muitos meses. Foi então que apareceu um outro sintoma: ataques de pânico que se manifestavam toda vez que eu ficava sentado durante períodos muito longos. Nada surpreendente, isto ocorria principalmente durante as reuniões do movimento. Eu tinha que lutar contra um desejo poderoso de sair correndo do quarto ou da sala de reuniões e continuar correndo pela rua. Durante nosso retiro semestral em Roma eu não pude sequer acompanhar as palestras de Chiara: eu suava e me contorcia, procurando dominar o impulso de sair dali. Ao mesmo tempo, o problema de minha sexualidade reprimida por tanto tempo já não podia ser ignorado. Eu agora sentia que precisava entender a verdadeira natureza de meus sentimentos. Eu sabia que os sintomas 
estranhos e angustiantes que me afligiam só iriam encontrar resposta fora da comunidade Focolare. (ibidem, p.423-4)

Urquhart iniciou seu processo de desligamento do movimento Focolares e descobriu que o grupo iria fazer de tudo para dificultar sua saída. Primeiro lhe ofereceram ajuda, recomendando um tratamento psiquiátrico com um médico do Movimento que, além de psicoterapia e de remédio, lhe recomendou o casamento: "um poderoso antídoto contra as tendências homossexuais, principalmente por causa dos filhos" (ibidem, p.427).

O movimento autorizou-o, mesmo que a contragosto e apenas em caráter temporário, a viver fora da comunidade. Sua família aceitou sua decisão com rapidez e Urquhart foi viver em um apartamento com sua irmã. Mas a liberdade tem preço: "Os primeiros problemas que encontrei foram de ordem financeira" (ibidem, p.429). O Movimento havia ficado com todos os honorários que ele havia recebido durante seis anos de voto de pobreza e não o ajudou a recomeçar sua vida "no mundo". "Sem recursos, eu saí da comunidade com muito menos, em termos de roupas e posses, do que quando entrei" (ibidem, p.431). A liberdade imediatamente produziu efeitos saudáveis.

Eu tinha dado a mim mesmo um prazo de seis meses para negociar minha libertação do Focolare, e este prazo foi realmente um período de pesadelos, de luta contra a resistência do movimento. E ainda por cima eu tinha de enfrentar meus próprios problemas de saúde. Mas quando entrei no meu novo apartamento, tudo passou. Aconteceu então uma coisa extraordinária. Os sintomas de pânico e de angústia que me perseguiam há mais de um ano literalmente desapareceram da noite para o dia. E estes sintomas foram substituídos por uma emoção muito simples, quase banal, uma emoção que surgiu com a força de uma revelação. Pela primeira vez em seis anos, desde que entrara para a comunidade Focolare, eu experimentava, não de forma sobrenatural ou divina, mas de forma simples e humana, uma sensação de felicidade natural - uma 
emoção que, de acordo com a doutrina do Focolare, simplesmente não existe. (ibidem, p.431-2)

Reconquistando sua independência, logo Urquhart foi descobrir o mundo, recuperar seu atraso cultural, estendendo seu círculo de amizades mais além das imposições do movimento. Conforme ele se afastava e seus laços se afrouxavam com o grupo, mais o Movimento o procurava e buscava enquadrá-lo, tentando manter domínio sobre Urquhart (2002, p.434). Ele resistia, embora o assédio e a pressão fossem fortes. Não querendo abandonar o Movimento de todo, Urquhart pensava, ingenuamente, em manter um contato mais livre, sem o peso das estruturas do Focolares. Mas isso seria impossível.

Mesmo muitos anos depois, quando, para falar claramente, a possibilidade deste controle já não existia mais, eles continuaram a me ver como um elemento em sua estrutura de poder. Depois que descobriram que eu não cederia às pressões, o assédio terminou abruptamente. Eu fui relegado à categoria daqueles que estão identificados nos arquivos do Focolare com um "M" - os mortos. (ibidem, p.437)

Parece necessário um grande esforço para superar os princípios integristas e explicitamente religiosos do Movimento que foram inculcados e que se sedimentaram na vida pessoal do antigo adepto. A doutrinação pode ter efeitos colaterais prolongados, tais como a necessidade de falar frequentemente do tempo vivido no Movimento, "para tentar dar um sentido ao que não tem mais sentido, para externá-lo e colocá-lo em perspectiva” (ibidem, p.438), pesadelos repetidos com a cena institucional (ibidem, p.442). Os "axiomas obsessivos do Focolares" desvalorizavam a vida humana corrente: amigos, família, trabalho, relações pessoais. Reencontrar o significado de tudo isso leva tempo. Urquhart recupera aos poucos a autoconfiança, seguindo a carreira de diretor de cinema. Mas deixou também de praticar a religião católica por cerca de dez anos (ibidem, p.439). 
Quanto à sua sexualidade, ele continuava fortemente influenciado pelo Movimento: "A opção que me fora apresentada pelo movimento e seus agentes era muito clara: eu poderia seguir minha natureza gay e levar uma vida de pecado, ou poderia me casar. Era muito simples" (ibidem, p.439-40). Um ano depois de sair do Movimento, ele se casou, mas isso não funcionou.

Eu não quero colocar a culpa de minhas ações na conta do movimento. Na realidade, eu e outros tivemos que pagar caro por elas, sete anos e dois filhos mais tarde, sob a forma de um divórcio confuso e amargo. [...] Mas ao tomar decisões - ou ao não tomá-las - a única matéria-prima com que temos de lidar somos nós mesmos. E quando me casei, após nove anos cruciais de doutrinação, eu era aquilo em que o movimento me transformara. (ibidem, p.440)

Conta que, finalmente, deparou com o grupo Quest, a organização dos gays católicos. "Na amizade simples e na humildade que encontrei entre os membros dessa organização, eu descobri que Deus não é propriedade exclusiva de nenhum movimento" (ibidem, p.442-3). Ele conclui seu relato com uma grande consciência, depois do seu longo percurso: "A rejeição daquilo que é humano é a maior heresia dos novos movimentos, pois é impossível ser cristão se antes de tudo a pessoa não for plenamente humana” (ibidem, p.444).

Esse percurso de Urquhart tem suas particularidades, mas não deixa de incluir também o singular. Nele podemos ver um exemplo das dificuldades de se desfazer da modelagem subjetiva a que são submetidos os indivíduos nessas instituições. Esse desligamento só se tornou possível mediante um processo que inclui rápidos e lentos momentos de crise. Os momentos de crise são constituídos pelo transbordamento da angústia e o indivíduo se vê projetado em uma ação que é mais uma passagem ao ato do que qualquer decisão refletida (para Urquhart, essa passagem ao ato se deu no terreno da sexualidade e como abandono temporário da religião católica; para outros, ela pode consistir na fuga ou simples abandono da organização). Os momentos lentos constituem uma dimensão paulatina 
do processo de separação em que o indivíduo vai exercitando a reversão dos "axiomas obsessivos do Focolares" que desvalorizam a vida corrente: amigos, família, trabalho, relações pessoais (tais momentos lentos incluem certas recaídas como a necessidade de falar frequentemente do tempo vivido no estabelecimento e a recorrência de pesadelos com a cena institucional, aparentemente para dar sentido ao sem sentido vivido e conjurá-lo). O caso em questão nos mostra, ainda, que a saída do estabelecimento institucional não se confunde com a saída da configuração subjetiva que a adesão e a permanência nela produziram (Ferreira; Lauand; Silva, 2005, p.144-9).

\section{Algumas observações sobre o fanatismo religioso e suas relações com as características das instituições totais}

De acordo com Dreyfus e Rabinow (1995, p.206), Foucault afirma que "as pessoas sabem aquilo que elas fazem; frequentemente sabem por que fazem o que fazem; mas o que ignoram é o efeito produzido por aquilo que fazem”. Por outro lado, a psicanálise há muito tempo nos ensina que nossas ações e palavras, quando se dirigem ao semelhante, como injunções, podem produzir efeitos bem mais amplos do que pretendíamos em nossas intenções iniciais. Trabalhamos com a hipótese de que os movimentos religiosos que estamos estudando desenvolvem práticas que podem ser pensadas como de caráter fanatizante. Com isso não pretendemos afirmar que necessariamente são constituídos por pessoas que possuem essa intenção deliberada. É possível que eles não consigam calcular os efeitos das práticas que implementam, nem visem conscientemente esse fim, entretanto esse parece ser um dos sentidos importantes de sua produção geral, de acordo com a literatura que temos compulsado. Assinalamos, de imediato, como principal característica da atitude fanática, a demanda radical de sentido de teor imaginário.

O fanatismo, independente do campo em que se manifeste (religioso, esportivo, político, ideológico etc.), tende geralmente à fuga 
da realidade. O fanatismo religioso reduz o indivíduo fanático a um escravo diante do senhor: seu líder, uma divindade, uma causa suprema ou uma fé cega. Enraíza-se num gnosticismo exacerbado, alimenta-se de um sistema de crenças absolutas e irracionais com o objetivo de servir um ser poderoso empenhado numa campanha contra o mal. O fanático se percebe investido de uma missão intransferível e inadiável de exorcizar o demônio das pessoas e coisas, ele combate contra as forças das trevas e busca salvar o mundo do caos e da perdição eterna. Sua causa suprema está acima de sua própria vida, da de sua família e inclusive das demais pessoas: ele é capaz de morrer ou matar por suas crenças.

Segundo Lima (2002), os sintomas do fanatismo incluem: orações, jejuns, privações, peregrinações, discursos monológicos e martírios, que podem levar ao sacrifício final do fanático, visando salvar o mundo das forças do mal que ele combate. $\mathrm{O}$ fanático não fala, fundamentalista, ele discursa para inculcar por meio da pregação religiosa sua crença ou doutrina, tornando a todos meros objetos de um desejo divinizado. Ele tem certeza e sua certeza é igual à verdade. $\mathrm{O}$ fanatismo religioso tem algumas características muito claras: um grupo ou um sujeito convencidos de que estão de posse da verdade com toda certeza, resistindo ao teste da realidade; querem impor a todos os demais de um modo despótico a sua "verdade", derivada de sua inspiração ou crença absoluta (buscam uma uniformização estereotipada da aparência, dos rituais, da linguagem, criando "chavões" e slogans próprios). A sua causa suprema é superior a tudo, inclusive à própria vida e a dos demais; o grupo se isola da coletividade, em busca de pureza, adotando um estilo de vida narcísico, fechado, sectário e uniformizante; com o tempo, o discurso do indivíduo ou do grupo torna-se repetitivo, bizarro, distanciando-se do bom senso na lógica comunicativa dialogal. Finalmente, perdem o sentido de respeito pelos diferentes modos de existência humana, em nome de uma causa transcendente absoluta.

O método de doutrinação fanática tem três etapas: inicialmente, busca seduzir pessoas para a "causa" do líder ou do grupo; depois realiza um processo de destruição da antiga personalidade, dis- 
solvendo ligações familiares, profissionais e sociais; finalmente, procura construir uma nova personalidade, recriada de acordo com os moldes, modelos e normas do grupo. O fanatismo é perigoso, pois revela uma intolerância extrema para com os diferentes (Lima, 2002).

Ao longo desta análise já deixamos entrever um princípio de explicação do fenômeno do fanatismo. É preciso acrescentar que a atitude fanática perece enraizar-se em circunstâncias sócio-histórico-culturais agonísticas, em personalidades de um matiz também particular ("Cultura do Narcisismo" e avidez carismática).

Em trabalho anterior arriscamos uma explicação para o fenômeno do fanatismo: contextos socioculturais agonísticos em termos do fechamento de perspectivas concretas e de ideais de desenvolvimento e mobilidade social; conjugados a personalidades narcísicas (regredidas do ponto de vista das relações interpessoais e objetais), que deixam tais indivíduos prisioneiros de demandas subjetivas radicais de sentido de teor imaginário. O preenchimento urgente e sem falhas dessa demanda é fator de estabilização psíquica para esses indivíduos. Porém, essa estabilização não deixa de ser claudicante, daí o desdobramento fanático, que é uma tentativa de conjurar, reiterando no próximo, por uma espécie de "performance" proselitista, a solução dos conflitos que no próprio fanático não acaba de se consolidar (Costa-Rosa, 1995).

A fanatização produz efeitos agonísticos de ritualização da existência, refletidos diretamente na subjetividade e no corpo dos indivíduos. Ela tem uma função congruente com a de certas práticas ritualísticas de outras instituições culturalmente mais arraigadas, como o candomblé e a umbanda, entre nós, e uma série de rituais das sociedades chamadas primitivas. Os efeitos maiores dessas práticas culturalmente estabelecidas podem ser definidos como ritualização da existência, de alto teor de simbolização, dado o caráter de tradição cultural do sentido que veiculam para o cotidiano e a vida em geral, dos indivíduos adeptos (Costa-Rosa, 1995).

Quanto à fanatização propriamente dita, podemos defini-la como uma espécie de ritualização malsucedida, agonística, que se 
inscreve diretamente na vida subjetiva e no corpo dos indivíduos aderidos; esse efeito parece vir do baixo teor simbólico do sentido veiculado. Esse não se inscreve mais em rituais compartilhados pela cultura mais ampla, mas na própria subjetividade, imprimindo-lhe uma instabilidade mais drástica, o que acaba derivando na atitude fanática e proselitista como seu desdobramento necessário (não contingente). Nessa perspectiva, pode-se dizer que o fanatismo proselitista é um dispositivo agonístico disparado para defender a precária estabilização psíquica conseguida com a adesão mística.

Em suma, uma forma de estabilização sustenta-se culturalmente no coletivo, liberando o corpo e a subjetividade individuais, não há "performance" gnóstica (maniqueísmo) nem fanática (proselitismo). A outra, carente de sustentação cultural e coletiva, toma o corpo e a subjetividade individual como suportes, acentuando a atitude gnóstica já induzida pelo ideário das instituições e presente na própria subjetividade dos adeptos, produzindo uma "performance" fanática extrema (proselitismo compulsivo), como meio de manter a precária estabilização psíquica conseguida com a adesão à organização.

Generalizando algumas de nossas hipóteses anteriores sobre o Focolares, podemos afirmar que os chamados novos movimentos religiosos presentes no atual contexto católico têm matizes nitidamente totalitários, pois se estruturam de acordo com o paradigma pré-moderno tridentino (Queiruga, 2003; Libânio, 2005, p.74-9). Estão alinhados com as forças hegemônicas eclesiais contemporâneas de matiz restauracionista, sendo alguns de seus traços mais marcantes: fanatismo, crescimento rápido e vigoroso, ausência de prestação de contas, segredo quanto a sua estrutura interna, silêncio total sobre a origem de seus recursos financeiros aparentemente ilimitados, método de recrutamento próprio de seitas, crenças esotéricas, perspectiva cultural limitada, repressiva e integrista, com posicionamentos morais conservadores e tradicionalistas. Triunfalistas, exercem um proselitismo agressivo. Mantêm segredo quanto às doutrinas arcanas que lhes conferem o sentido de unidade e coesão interna. 
O neofundamentalismo ultrapassa facilmente aquele mínimo de segurança normal, necessário, desviando-se pelas vias da patologia social, oferecendo a pessoas inseguras, ansiosas, neuróticas um apoio emocional, em vez de ajudá-las a uma decisão livre, pessoal e consciente. É enorme risco construir uma identidade sobre tipos neuróticos, seja pela via da submissão, seja pela via do autoritarismo: ambos inseguros, incapazes de assumirem em liberdade decisões fundamentais. Fogem, temem a liberdade. Esta é ameaça por demais grande para suportá-la com tranquilidade. A autonomia madura revela-se na calma e paz em suportar e enfrentar o diferente, em atitude de diálogo. As situações autoritárias são patogênicas, enquanto que as democráticas, livres, dialogais são terapêuticas. Ora, quanto mais uma identidade for construída à base do diálogo, do consenso, tanto mais ela revelará o caráter sadio de seus construtores e permitirá que ela também possa ser vivida sadiamente pelos seus membros. (Libânio, 1984, p.158)

Esses movimentos não parecem trazer respostas novas para problemas novos, ao contrário, buscam antigas fórmulas para problemas que não são os da contemporaneidade, parecem "vinho velho em velhos odres". Sob o prisma de tais movimentos, seria o cristianismo incompatível com a modernidade democrática, com a liberdade (como autonomia), com a igualdade (traduzida como reconhecimento das diferenças, da especificidade desejante, dos conflitos e contradições comuns, condições de possibilidade de crescimento) e com a fraternidade (enquanto solidariedade na ação conjunta dos projetos coletivos e no enfrentamento das vicissitudes na esteira do devir)? Ampliando nosso ponto de vista, pensamos que não, juntamente com diversos autores que propõem a superação do Paradigma Tridentino e a construção de uma nova realidade eclesial. ${ }^{8}$

8 Nessa direção, podemos citar os seguintes autores: Brighenti (2001); Comblin (1999, 2002); Libânio (1984, 2000, 2003, 2005); Queiruga (2001); e Morano (2003). 


\section{6 \\ AtRAVESSAMENTOS INSTITUCIONAIS: ${ }^{1}$ \\ O HOSPITAL GERAL, O HOSPITAL \\ PSIQUIÁTRICO, A PRISÃO E O INTERNATO \\ ESCOLAR}

Esses estabelecimentos institucionais têm como característica global o fato de existirem para dar conta de certos objetivos valorizados por toda a sociedade, possuindo funções oficiais culturalmente legitimadas, expressas em estatutos, regimentos e legislações.

A semelhança entre o hospital geral e o psiquiátrico pode ser considerada explícita em muitos aspectos. Ambos são denominados "hospitais", gozam do mesmo estatuto legal que os define como instituições médicas, lugares onde as pessoas se convertem em pacientes e recebem tratamento de especialistas e cuidados gerais, sob supervisão médica, dos enfermeiros e demais funcionários. Muitas características do hospital psiquiátrico possuem uma continuidade histórica direta com as do hospital geral: os dois sustentam o compromisso oficial de cuidar das doenças e possuem seu fun-

1 Cf. Lourau (1995). As instituições que formam a malha social atuam em conjunto, se entrelaçam e interpenetram nos diversos níveis do funcionamento, da produção instituinte e da reprodução do instituído. A interpenetração na direção da função e da reprodução é denominada atravessamento, possui orientação conservadora, serve à exploração, dominação e mistificação, apresentando-as como benéficas e necessárias. A interpenetração no sentido do instituinte, do produtivo, criativo, revolucionário e transformador se denomina transversalidade (Baremblitt, 1998; Lourau, 1995). 
damento legal no conceito de responsabilidade médica. Em ambos encontramos uma distinção rígida entre os membros que recebem tratamento e os que o oferecem; há também as distintas enfermarias especializadas em diferentes enfermidades; a enfermaria é a unidade básica de funcionamento. Seus funcionários incluem os mesmos grupos profissionais discriminados por ocupação: médicos, enfermeiros, auxiliares, administradores. Também existem semelhanças na estrutura formal geral: a hierarquia costuma ser bastante estratificada e organizada por funções e abrange um sistema administrativo rígido que muitas vezes não possui integração e acaba por dar origem a facções antagônicas que vivem em disputas e rivalidades (Benelli; Costa-Rosa, 2003a).

As diferenças entre esses dois estabelecimentos podem ser apreciadas na preparação, nas tarefas e nos papéis dos funcionários, embora os quadros dos hospitais sejam parecidos. O médico psiquiatra tem funções mais amplas no hospital psiquiátrico do que o clínico geral ou o especialista no hospital geral. Também há diferenças entre o enfermeiro psiquiátrico e o cirúrgico, pois o primeiro desempenha um papel mais amplo na vida dos internados. Essas diferenças relativas aos papéis e funções do quadro de funcionários deriva das necessidades diversas dos pacientes. No hospital geral, a internação do paciente costuma ser o mais breve possível, geralmente fica na cama e o trabalho dos médicos e enfermeiros se refere ao seu tratamento e cuidados físicos. As relações dos profissionais com os pacientes podem chegar a ser momentaneamente intensas, mas se mantêm dentro de certos limites e terminam com facilidade. A cama, no hospital geral, simboliza o status do doente que se encontra em situação de dependência e de recebimento de cuidados e no qual se localizam os esforços terapêuticos dos funcionários.

Já no hospital psiquiátrico, as necessidades dos internados são outras. Aqui também pode ser necessário um esforço para salvá-lo da morte física, mas o esforço maior está concentrado em ajudá-lo a sair do sofrimento psíquico no qual se encontra. O hospital se converte para ele numa comunidade de vida: ali ele vive indefinidamente, recebe tratamento, trabalha, faz amigos e inimigos 
etc. Geralmente não fica na cama, está sujeito a raras intervenções cirúrgicas e se torna um participante muito mais ativo com relação aos esforços terapêuticos como em toda a vida institucional. Mas também é o menos capaz de autocontrole, exigindo dos funcionários um grau maior de preocupação, juízo moral e respostas defensivas pessoais. Torna-se necessário criar todo um ambiente que possa satisfazer as necessidades psicossociais do indivíduo. Os funcionários têm uma responsabilidade direta na evolução dessa comunidade, contribuindo com sua preparação profissional e qualidades pessoais.

Vários autores da corrente institucionalista ${ }^{2}$ têm promovido uma forte crítica dos conceitos psiquiátricos tradicionais, a partir do reconhecimento das diferenças entre o hospital geral e o psiquiátrico. O primeiro tem servido como modelo de organização para o segundo e podemos dizer que o hospital psiquiátrico foi se separando aos poucos do geral, constituindo-se como comunidade terapêutica (Castel, 1978). Szasz (1979) realizou um amplo questionamento do modelo médico de "doença" - um processo patológico subjacente com uma etiologia específica e um desenvolvimento natural que responde a uma técnica precisa de tratamento - como fundamento para compreender e ajudar as pessoas que têm dificuldades para viver, devido ao fardo do sofrimento psíquico.

O hospital psiquiátrico pode ser considerado uma forma de organização instrumental, dirigida para algumas finalidades específicas. Elas podem ser enumeradas como as seguintes: a) função de reclusão, visando à proteção da comunidade por meio do encarceramento num ambiente controlado, dos indivíduos que integram o amplo e indiscriminado conjunto dos designados como perigosos devido à sua "doença"; b) função de manutenção da vida, que proporciona a proteção dos próprios "doentes" contra seus impulsos autodestrutivos; c) função de cuidado, oferecendo conservação e cuidado das pessoas "doentes" durante o tempo em que forem con-

2 Tais como Rotelli et al. (1990); Baremblitt (1998); Costa-Rosa (1987, 1995, 2000, 2006). 
sideradas irresponsáveis e incapazes de viver no seio da sociedade como cidadãos independentes; d) função terapêutico-reabilitante: engloba o conjunto das formas de intervenção no psiquismo, no corpo ou na situação vital do paciente, para que sua vulnerabilidade se reduza e ele consiga desenvolver recursos internos de tal modo que possa retomar e prosseguir com sua vida em sociedade.

A preponderância relativa desses objetivos e os modos de operacionalizá-los variam muito, tanto entre as instituições quanto entre os diferentes grupos dentro de uma delas, além dos momentos históricos diversos. ${ }^{3}$ Entre suas funções adicionais, os hospitais psiquiátricos devem satisfazer diversas necessidades do quadro de funcionários e manter a integração do estabelecimento. Cada vez mais, essas instituições funcionam como locais de investigação e capacitação profissional de psiquiatras, enfermeiros, psicólogos, assistentes sociais etc. Essas funções educativas e de investigação influenciam no modo como são tratados os pacientes.

Os hospitais psiquiátricos variam muito quanto aos seus objetivos específicos, ao ambiente que proporcionam para os pacientes, pelas condições de admissão e de alta, pelos tipos de tratamento oferecidos, que parece difícil falar do hospital psiquiátrico. Consideramos que o que eles possuem em comum são os objetivos gerais que apontamos antes. Um hospital pequeno, aparelhado com uma boa equipe de profissionais, preocupa-se principalmente com os objetivos terapêuticos, mas a função de reclusão também desempenha um papel importante nos seus assuntos. Já um grande hospital público, inversamente, parece cumprir primeiramente a função de reclusão e custódia para a maioria dos internados. Entretanto, ainda que sua ideologia terapêutico-reabilitadora lhe proporcione apenas uma racionalização profissional para justificar procedimentos desumanos, também pode oferecer um conjunto de princípios

3 Isso pode ser verificado, por exemplo, em Foucault (1977, 1999a); Castel (1978); Costa-Rosa (1987); Antunes (1991); França (1994); Nicácio (1994); Figueiredo (1996); Yasui (1999). 
racionais e meios vantajosos que lhe permitem adotar medidas terapêuticas e mudanças construtivas.

Outra característica desse estabelecimento é a divisão dos seus membros em duas categorias distintas bem definidas: os internados (pacientes) e os funcionários (incluindo a equipe administrativa). Para os funcionários (todos aqueles que recebem salário pelos seus serviços) o hospital psiquiátrico é um lugar de trabalho no qual aprendem e exercem suas ocupações profissionais, prestam serviços que acreditam ser úteis e recebem pagamento por isso. Geralmente passam apenas a parte do seu dia no hospital, enquanto trabalham.

O paciente pode ser definido como um "cliente" do hospital psiquiátrico, na medida em que pode contratar os serviços de um pequeno hospital particular, como contrataria qualquer outro serviço. Pode ser que um indivíduo se interne voluntariamente nele, ou num hospital psiquiátrico público de orientação terapêutica. Mesmo nesses casos, ele deverá suportar certo grau de estigmatização, sentindo-se defeituoso e envergonhado. Ele também abre mão, em certa medida, de seus direitos civis e se submete à tutela protetora do hospital.

No extremo oposto, com grande frequência, como nos casos de internação legal em grandes hospitais psiquiátricos públicos de custódia, o caráter de cliente é mínimo e o paciente se considera a si mesmo como um "internado". Goffman (1987, p.109-43) apresenta um relato vívido da "carreira moral do doente mental", descrevendo com grande perspicácia o paciente como um internado.

Os conceitos de cliente e de internado dão uma imagem adequada da condição do paciente internado num hospital psiquiátrico. As características de cliente se manifestam a partir do fato de que se trata de uma pessoa autônoma, com iniciativa própria e responsabilidade, que utiliza serviços terapêuticos. O conceito de internado denota os aspectos restritivos da situação do paciente, indicando seu confinamento legal dentro do hospital, a restrição dos seus direitos e status civis, sua submissão à autoridade administrativa da equipe dirigente, autoridade que não possui paralelo com nenhuma outra na sociedade externa. 
O doente é um interno, um membro residente do hospital, um habitante desse mundo limitado; ele ocupa uma posição formalmente definida na estrutura do estabelecimento. O internado se vê diante de uma ampla variedade de oportunidades e de exigências, é pedida ou oferecida a ele uma série de ocupações ou atividades, sendo a participação no tratamento apenas uma delas. Todas as suas necessidades como pessoa (recreação, solidão, estudo, intimidade, relações familiares, hábitos particulares de higiene, alimentação etc.) serão satisfeitas ou rigidamente controladas (inclusive negadas) dentro do próprio estabelecimento. Finalmente, o paciente deve se adaptar ao hospital, atendendo as solicitações que lhe são feitas e as oportunidades oferecidas, a fim de que, no melhor dos casos, chegue a se tornar uma pessoa ressocializada e obtenha alta num período de tempo razoável e sem grande prejuízo para sua integridade pessoal.

Figueiredo (1996) estudou a evolução do hospício no Brasil, demonstrando que a expressão hospício, como sinônimo de casa dos loucos, é uma tradição tipicamente brasileira. Admite que, em outros países, o hospício abrigou doentes mentais, mas que a expressão não se tornou tão tradicional quanto no Brasil, ao referir-se ao hospital psiquiátrico. Aponta ainda que a expressão "hospício" está ligada com a noção de caridade, que impregnou esse modelo assistencial, mesmo depois de ter sido denominado de diferentes formas: casa de saúde, sanatório, manicômio, hospital psiquiátrico, entre outras. O hospício no Brasil, ao evoluir de uma hospedagem aos desamparados para um estabelecimento que se ocupa com doentes mentais, carregou em sua evolução a noção de caridade.

Enfatizou que o controle social, considerado em seu aspecto subjetivo, enquanto pecado, culpa e redenção, e em sua dimensão exterior como isolamento, contenção e punição, está na base do advento do hospício como casa de loucos no Brasil, o que ocorreu mesmo antes da chegada da Psiquiatria. O período histórico no qual emergiram os primeiros hospícios de alienados no país indica que o reconhecimento da existência de problemas socioeconômicos exigiu medidas imperiais de controle social. 
A partir de então, o autor examina as políticas de saúde mental desenvolvidas no Brasil desde a segunda metade do século XIX. Ele considera que elas se caracterizam até hoje com traços do binômio caridade-controle social, incidindo no espaço psiquiátrico e conduzindo a procedimentos não científicos.

Segundo o pesquisador, a intervenção da prática psiquiátrica no hospício de alienados, no final do século XIX, representou o ingresso do saber médico entre as culturas de caridade e controle social, já estabelecidas, e passou a conviver com elas, numa interação complexa.

Figueiredo (1996) conclui que o "hospitalocentrismo" que até o momento caracterizava as políticas de saúde mental não se deve apenas a razões de mercado, mas também a uma cultura enraizada no país, herdada da caridade e do controle social, que entende que o lugar dos loucos é no hospício. O hospital psiquiátrico deve ser rediscutido quanto à sua importância e ao seu papel nas políticas de saúde pública e outros modelos assistenciais deveriam ser estimulados, integrados em ações comunitárias.

As semelhanças entre a prisão e o hospital psiquiátrico são indicadas por Goffman (1987) e Levinson e Gallagher (1971). Essa proximidade aumenta se considerarmos que a prisão não evoluiu historicamente como as instituições médicas (Foucault, 1999b). As principais tarefas desempenhadas pelos funcionários (equipe dirigente) desse estabelecimento diferem de modo superficial das empreendidas pelas equipes dos hospitais psiquiátricos. Entretanto, os critérios oficiais que orientam a política institucional do presídio são distintos.

Os dois estabelecimentos mostram certas semelhanças fundamentais na sua estrutura organizacional, nos fins e na natureza da condição dos internados. Nos dois casos, encontramos a divisão dos membros em reclusos e equipe dirigente; ambos exibem as características estranhamente combinadas e artificiais da comunidade "quase-burocrática". Os objetivos da prisão podem ser apresentados nos mesmos termos que os do hospital psiquiátrico: reclusão, custódia e reabilitação. 
Assim como o hospital psiquiátrico pode ser considerado como uma comunidade terapêutica que busca a reabilitação psicossocial, o sistema correcional da prisão procura a reabilitação do presidiário, oferecendo-lhe a possibilidade de mudança psicológica. A natureza da mudança que se deseja e os meios apropriados para alcançá-la se interpenetram de diversas maneiras em diferentes hospitais e em diferentes prisões, tanto no que concerne à equipe dirigente como quanto aos reclusos. Idealmente, essa mudança psicológica nos presidiários implicaria uma maior força moral, competência social, maturidade interior e saúde emocional. No caso limite, o objetivo da equipe dirigente é impor obediência, e o do presidiário é continuar sendo o que é, sem envolver-se em maiores dificuldades, quando não aperfeiçoar-se na sua condição de indivíduo do submundo.

O colégio interno também tem aspectos em comum com as instituições anteriormente descritas. Novamente encontramos a divisão entre uma equipe de profissionais constituída por professores e administradores que procuram promover várias formas de mudanças psicológicas no grupo dos membros residentes (os estudantes internados) por cujo bem-estar geral são responsáveis em grande medida.

No paralelo que podemos estabelecer entre os fins educativos do internato escolar e os objetivos terapêuticos-correcionais do hospital psiquiátrico e da prisão, existe mais do que uma simples analogia. As três organizações procuram (de modos que variam tanto entre si quanto dentro de cada uma) promover o desenvolvimento pessoal e os conhecimentos sobre o caráter, o conceito sobre si mesmo, a competência e os recursos psicossociais que significarão uma diferença na vida dos membros residentes depois da sua graduação. Podemos falar em uma "terapeutização" da Pedagogia e uma "pedagogização" da terapia.

A função de custódia corresponde em graus semelhantes. Como membro da comunidade escolar, o estudante depende em grande medida do que o colégio lhe proporcione, quanto ao seu bem-estar, alojamento, recreação, saúde etc. Ele também está bastante sujeito 
ao sistema de autoridade e controle institucional (normas sobre a admissão, expulsão, regulamentos, aproveitamento acadêmico e comunitário e condições de graduação). As funções de reclusão podem ser menos proeminentes, pois ninguém se torna aluno em regime de internato por mandado judicial. Mesmo assim, alguns alunos podem sentir o colégio como um ambiente carcerário e restritivo, ao qual foram entregues por seus pais. ${ }^{4}$

Há uma série de questões que são comuns ao internado no colégio e no hospital psiquiátrico. Ambos constroem sistemas de princípios racionais ideológicos que definem o bom internado e o bom estabelecimento. Avaliam o estabelecimento em termos ideológicos e quanto ao significado emocional pessoal que tem para eles. Devem decidir o que ocorre em suas pessoas, um com relação ao processo formativo (conhecimentos, capacidade de ocupação, características de sua personalidade) que lhe é oferecido e o outro, quanto aos seus problemas psiquiátricos; entre o que são agora e o que querem chegar a ser. Assim como as dificuldades e os sentimentos do paciente o motivam para o trabalho terapêutico, o estudante é estimulado pela sensação de ignorância e imaturidade a participar do processo educativo. O conhecimento das próprias limitações e o desejo de mudanças interiores serve de estímulo para esforços educativos e terapêuticos na medida em que são acompanhados pela percepção do próprio valor pessoal e de um ambiente que valorize e possibilite esse esforço.

O caminho da reabilitação psiquiátrica (Costa-Rosa et al., 2003) também tem sua analogia no estudante internado. Ele também enfrenta um vasto conjunto de exigências e oportunidades dentro e fora do colégio. Não pode satisfazer todas nem usar todos os recursos disponíveis. É preciso fazer certa seleção, e o conceito do que é importante para o estudante pode não ser o mesmo para o corpo docente ou para a administração.

4 As concepções do estudante que vive num internato escolar de Hesse (1970, 1980); Rego, (1979); Trevisan (1985); Lautréamont (1986); Musil (1986); Perrone-Moisés (1988); Pompéia (1997); Freitag (2001) e Benelli (2002) têm muito em comum com a apresentada sobre o paciente como internado. 
A vida pessoal do estudante dentro do estabelecimento, tanto no dormitório quanto e em outras partes, tem um grande significado para seu desenvolvimento, além de sua importância para atingir os fins educativos mais concretos. Isso é semelhante ao que se passa entre os membros internados num estabelecimento psiquiátrico. O estudante responde muito à cultura geral de seus pares e às alianças e rupturas transitórias que se produzem dentro do corpo estudantil, com os professores e com a administração. A relação entre os estudantes, ainda que menos ameaçadora do que a que existe entre pacientes, costuma ter aspectos problemáticos que causam ansiedade. $\mathrm{O}$ estudante pode se sentir menos ameaçado pelos problemas mentais de seus colegas (embora isso também possa acontecer), mas ainda tem motivos para se preocupar com eles. Surgem questões relativas ao desempenho acadêmico, rivalidades, inveja, temores, medo do fracasso, disputas, competição por reconhecimento etc.

Diferentemente do paciente internado, um estudante de colégio interno sente orgulho por pertencer a um colégio, como resultado de esforços anteriores e como meio de obter conquistas vitais. $\mathrm{O}$ estudante não perde totalmente seus direitos civis de cidadão e o tempo de sua permanência geralmente está fixado de modo claramente delimitado.

A participação na vida colegial do internado pode ser não apenas uma oportunidade, mas também motivada pela pressão dos pais, professores, pares e outros. Os aspectos coercitivos da vida no internato escolar, ainda que menos explícitos e brutais do que os do hospital psiquiátrico, também podem ser mais massificantes e difíceis de se enfrentar. Existem as possibilidades vergonhosas do fracasso acadêmico, da incapacidade intelectual, de mudar muito ou pouco antes da formatura.

Podemos dizer que o processo educativo deve promover uma liberação sublimada dos impulsos, uma iluminação da consciência e uma maior diferenciação e integração da personalidade do indivíduo. Para alcançar esses objetivos, as instituições educativas devem proporcionar as condições psicossociais sob as quais os estudan- 
tes possam tratar essas questões de modo positivo e construtivo. Um conceito adequado para pensarmos o estudante é considerá-lo como um ser em transição, como uma pessoa em processo de desenvolvimento.

\section{Paradoxos disciplinares do funcionamento institucional}

Goffman (1987) e Foucault (1999b) apresentam os operadores institucionais em funcionamento no internato que produzem a realidade psicossocial dos atores no contexto do estabelecimento: há duas categorias analíticas fundamentais que se desdobram em outras categorias ou operadores. Entendemos o internato como uma "instituição totalitária e disciplinar" produtora de efeitos predominantemente subalternizadores, alienantes e resignadores nos internados. Parafraseando Goffman (1987, p.249), que afirma que não são as teorias psiquiátricas que organizam o modo concreto de funcionamento das instituições de tratamento mental, poderíamos dizer que o internato tende a ser organizado por práticas outras, além daquelas que procura implementar de modo oficial. Ele faz mais do que diz, embora de certa forma também poderíamos dizer que faz menos do que propõem seus discursos pedagógicos, psicológicos técnicos e científicos. O que pode produzir o internato escolar, estabelecimento criado pela filantropia patronal para educar os pobres "desvalidos da sorte"? Funcionando a partir das coordenadas do paradigma filantrópico, o internato tende a enquadrar e uniformizar a preparação dos indivíduos pobres, promovendo ao mesmo tempo proteção, prevenção, controle, subordinação, discriminação, subalternidade, no sentido da produção de indivíduos dóceis e úteis que, apesar da situação de vida absolutamente desfavorável, não ingressarão na criminalidade nem na rebeldia contestadora da (des) ordem institucionalizada, apesar dos diversos adendos "renovados" e "participativos" que tenta implementar visando reformar-se, mas não se transformar (Benelli, 2007, p.309-84). 
O internato, enquanto instituição total e disciplinar, é constituído por outros tantos operadores: "a técnica do enclaustramento" (ingresso do indivíduo num espaço institucional fechado de controle, visibilidade e observação de sua conduta externa); "a tutela econômica" (com a exclusão do indivíduo do mundo do trabalho profissional assalariado); "o regime de internato": microcosmo particular, de características nitidamente totalitárias (Goffman, 1987) no qual se estabelecem mecanismos de controle sobre a organização dos indivíduos no espaço institucional, além do controle da informação; "o panoptismo" (Foucault, 1984, 1988, 1999b) que se instala com suas estratégias de vigilância hierárquica, sanção normalizadora e técnicas de exame variadas (mecanismos de controle institucional que produzem comportamento adequado, medo, apatia e resignação).

A "dinâmica psicossocial totalitária e disciplinar" que se estabelece automaticamente sobre o conjunto dos atores institucionais promove a "vigilância e controle mútuo, gerando relações de poder antagônicas" entre diversos subgrupos de alunos internados e entre os dirigentes e o conjunto dos internados. As possibilidades educativas do estabelecimento de formação são colocadas em xeque, quando não inviabilizadas, pelo panoptismo disciplinar (o olhar, o controle dos corpos e da informação, o manejo e administração do tempo, do dinheiro, do trabalho, do sexo, da liberdade, da autonomia, do poder político).

Até que ponto um indivíduo consegue fazer frente às determinações sócio-históricas e institucionais? Entendemos que ele é um produto/produtor do ambiente sócio-histórico e institucional. Uma perspectiva centrada no sujeito individual pode entendê-lo como uma realidade completa e de certa forma, fechada em si mesma, como se um indivíduo se desenvolvesse solitária e autonomamente em um tubo de ensaio, numa estufa, e não no convívio social e cultural humano mais amplo, que se relaciona com um mundo e com objetos que lhe são externos, também entendidos como realidades autônomas, completas e distintas do sujeito. Nesse caso uma coisa seria o sujeito, outra o mundo, o ambiente, a reali- 
dade social e histórica. Estamos aqui, evidentemente, no paradigma sujeito-objeto, paradigma dicotômico e não dialético.

Nesse sentido, o sujeito seria dotado de uma vontade potente, capaz de enfrentar com êxito as determinações sócio-históricas e institucionais. O voluntarismo é a crença romântica na capacidade que o sujeito (sendo distinto e autônomo, exterior e independente do ambiente sócio-histórico e institucional) tem de fazer frente a todas as adversidades e contrariedades ambientais, aproveitando seus aspectos positivos e as oportunidades de crescimento que lhe são oferecidas no estabelecimento. Mesmo que haja falhas, problemas ou falta de consistência na oferta institucional, o sujeito deveria ser capaz de perceber e aproveitar os aspectos positivos da realidade do estabelecimento institucional para seu crescimento pessoal. Esse seria realmente o protagonista do seu processo formativo! Estaria personalizando a formação, ao assumi-la de modo pessoal e responsável. O sujeito pode tudo, basta querer. Caso o sujeito não tivesse êxito, seria por incapacidade, preguiça ou comodismo.

A perspectiva centrada no estabelecimento institucional vai destacar os aspectos condicionantes e determinantes da estrutura ambiental sobre o comportamento e o desempenho do sujeito. Nesse caso, o sujeito seria produto condicionado por poderosos determinantes, sobrando exíguo espaço para a autonomia, para o exercício da vontade pessoal, tornando a capacidade de escolha e de decisão bastante difíceis. $\mathrm{O}$ sujeito então não poderia nada.

Buscando superar essas perspectivas dicotômicas nas quais o sujeito pode tudo ou não pode nada, podemos pensar uma abordagem dialética na qual o sujeito é produto/produtor do ambiente sócio-histórico e institucional, condicionado, mas não determinado em último grau. Ao entender quais são os determinantes que o marcam e condicionam, o sujeito pode interferir nesses determinantes, agindo no plano político, tanto macro quanto micropolítico.

Uma abordagem genealógica procura entender a produção social de sujeitos e instituições, de sujeitos nas instituições a partir da intersecção entre saberes, poderes, discursos, práticas e ética. As instituições não são vistas como obstáculos ou como promotoras 
do desenvolvimento do sujeito, são intermediários necessários e possuem funções sociais múltiplas: educação, tratamento, punição, normalização. Nem todas essas funções são explícitas. Normalmente, uma instituição declara em seus estatutos oficiais quais são seus objetivos, finalidades, metodologia, clientela etc. Nesse sentido, toda instituição se apresenta como portadora de uma encomenda social que geralmente tem grande dificuldade em atender (quando não falha redondamente). É onde e quando ela falha que podemos detectar sua provável função predominante, que deve ser deduzida de sua estrutura e do sentido global de sua produção social.

Os estabelecimentos de internação pretendem ser "educativos" de alguma forma, mas falham no seu intento. Quando a escola falha em sua função educativa, ela se revela como estabelecimento disciplinar e normalizador. Quando o manicômio falha em tratar e curar a loucura, ele se revela como aparelho de gerenciamento da subjetividade desviante do padrão dominante (Goffman, 1987). Quando a prisão falha em ressocializar o criminoso e o infrator, ela se revela como gerenciadora da delinquência, forma recuperada e adestrada da ilegalidade geral (Foucault, 1999b).

Quando o seminário falha em sua tarefa de preparar presbíteros servidores do povo cristão, ele tem sucesso enquanto instituição clericalizadora. Inclusive o imaginário, as representações sociais hegemônicas no ambiente do seminário são as do padre clericalizado (Benelli, 2006, 2007). Quando a escola falha no trabalho de dar às crianças pobres o acesso ao mercado de bens culturais construídos pela humanidade, ela funciona de modo muito eficaz no sentido de promover a "expulsão" de um contingente de indivíduos para os quais não está previsto mesmo um lugar na sociedade de trabalho e tampouco na de consumo. Quando a Assistência Social falha em promover a inclusão social efetiva, ela tem sucesso ao implementar estratégias bem-sucedidas de gerenciamento e gestão do "problema social" (Castel, 1987; Donzelot, 2001; Benelli, 2010). Desse modo, podemos dizer então que elas produzem outros efeitos, diversos dos que diziam em seus discursos oficiais. Por isso, as consideramos estruturalmente (des)educativas. 


\section{ConClusÃo \\ EFEITOS ÉTICOS DA INTERNAÇÃO COMO ESTRATÉGIA INSTITUCIONAL}

Vamos desenvolver, a modo de conclusão, algumas considerações relativas à especificidade dos fenômenos psicossociais que se produzem nas diversas instituições totais. Tais fenômenos costumam ser desconhecidos e ignorados por profissionais do Judiciário, da Medicina, da Pedagogia, da Psicologia e do Serviço Social, e por técnicos administrativos que trabalham nesses estabelecimentos. Muitas vezes tais equipes dirigentes estão imbuídas de boas intenções e de muito idealismo, quando não também de uma grande ingenuidade pedagógica (Conselho Federal de Psicologia, 2010a, 2010b).

Há uma série de pressupostos discutíveis no encaminhamento, por exemplo, de medidas socioeducativas para crianças e adolescentes infratores das leis, pois dificilmente esses momentos da existência humana são adequadamente problematizados. Há enfoques muito diversos, por exemplo, quanto ao que seja a infância (Rizzini; Pilotti, 2009) e adolescência (César, 2008). Supõe-se que a privação de liberdade ou que a semiliberdade possam ser utilizadas para implementação de procedimentos ressocializadores, preventivos, personalizados e promotores de integração e promoção social, além da inclusão no mercado de trabalho, por meio da escolarização e da profissionalização. É ingênuo supor que se pode confinar um 
grupo de indivíduos num estabelecimento por meio de uma decisão judicial e criar aí um ambiente saudável e potencialmente pedagógico no qual se possa oferecer um acompanhamento educativo pela equipe de educadores, promovendo uma rotina integradora e uma convivência saudável. Isso também se aplica no caso dos adultos encaminhados para o sistema prisional.

A Psicologia, a Pedagogia e a Assistência Social são saberes científicos que gozam de reconhecimento e credibilidade social incontestes na atualidade, embora seus profissionais ainda sejam mal remunerados, sobretudo nos serviços públicos, tanto municipais quanto estaduais. Pensamos que essas Ciências Humanas estão sendo utilizadas como estratégias de controle disciplinar em diversos empreendimentos educativos, socioeducativos e ressocializadores, de modo especial nos estabelecimentos que empregam limitações da liberdade individual criando regimes de internação, de semiliberdade ou de confinamento prisional.

Psicólogos, pedagogos e assistentes sociais devem, nesses contextos institucionais, oferecer um acompanhamento personalizado e sistemático para os indivíduos reclusos, levando-os a refletirem sobre as infrações legais que cometeram e causaram seu aprisionamento. Têm a função de corrigi-los, educá-los, modificando sua conduta, devem ressocializar os internados. Aí então exercem o papel de "técnicos do comportamento, engenheiros da conduta, ortopedistas da individualidade" como definiu Foucault (1999b, p.244). Além do mais, eles devem elaborar relatórios sistemáticos para as análises e decisões do Judiciário, que tem fome de psiquiatria e vergonha de punir, precisando do respaldo científico desses saberes (ibidem, p.251). Seu trabalho permite que os juízes promulguem "vereditos terapêuticos e encarceramentos readaptativos" (ibidem). Desses relatórios dependem a extinção ou a continuidade da medida determinada pela autoridade judicial. É um grande poder e uma enorme responsabilidade para esses profissionais.

Os casos que analisamos na literatura no Capítulo 5 demonstram os impasses entre discursos altruístas e a organização concreta dos estabelecimentos de enclaustramento, com suas práticas 
cotidianas contraditórias. As aporias pedagógicas, psicológicas e disciplinares tornam-se compreensíveis quando situamos esses estabelecimentos no contexto da sociedade disciplinar e dos seus paradoxais dispositivos. Educar, formar ou socializar em estabelecimentos de internação implica vigiar e punir (e educar e tratar), por mais difícil que seja admitir essa possibilidade.

As transformações no campo social brasileiro relativas ao desenvolvimento econômico e urbano influenciam e são influenciadas dialeticamente pelas ações e reações do contexto histórico do capitalismo mundial. Há influências recíprocas entre essas instâncias e ambas incidem de modo determinante nas instituições de formação, educação e ressocialização que funcionam em regime de internação. São as coordenadas do campo sócio-histórico global, os movimentos contraditórios do complexo cenário político-pedagógico-jurídico brasileiro e a atual conjuntura sociocultural os determinantes mais gerais que incidem na estrutura, funcionamento e na produção da subjetividade nas instituições de confinamento.

Há uma grande resistência em se cogitar e propor inovações institucionais quando se projetam caminhos realistas e viáveis quanto aos problemas e aporias do sistema prisional e socioeducativo para adultos, adolescentes e crianças no país. As propostas permanecem no campo intrainstitucional mais estrito, buscando novas técnicas e "receitas" prontas que pudessem resolver as dificuldades, mas não ousam dirigir-se para suas exigências práticas, as quais não nos parecem factíveis sem transformações políticas no plano das relações de poder. Apenas novas e belas construções teóricas, pedagógicas, psicológicas ou médicas, não podem transformar a realidade das coisas. A realidade resiste aos discursos e aos livros que propõem somente belos ideais e valores pessoais, sem aludir às mediações coerentes e consequentes na prática institucional concreta. Diante do discurso poético e idealista, a grande possibilidade é que tudo permaneça como está.

Compreendemos a importância e a incidência do contexto sociocultural e político no processo pedagógico institucional. Mas estamos sublinhando, sem negar o anterior, que uma das grandes 
dificuldades está em problematizar de modo específico o próprio dispositivo institucional de educação: o internato. Temos procurado demonstrar como esse dispositivo tem formas de funcionamento automáticos que precisam ser discutidas e pensadas.

Aparentemente, o processo formativo, educativo ou psicopedagógico, socializador ou ressocializador, implementado por uma equipe dirigente constituída por profissionais e técnicos educadores desconhece a dimensão psicossocial do funcionamento dos estabelecimentos de internação. É essa dimensão psicossocial que está na base dos "problemas pedagógicos" que os educadores enfrentam na execução da sua tarefa: os internados constituem um grupo, que pode ser grande ou pequeno, mas que se distingue do "indivíduo" abstrato e anônimo, situado fora de todo contexto institucional concreto. O grupo dos internados é uma realidade institucional organizada a partir do exterior por uma administração burocrática que estabelece as coordenadas gerais da vida no estabelecimento. É a equipe de educadores dirigentes que outorga, no seu papel de administrador, as estruturas internas do estabelecimento, consignadas em leis e normas, estabelecidas em regimentos, aos educandos internados. Além disso, há regras não escritas que funcionam no cotidiano institucional de modo surpreendentemente efetivo, para aquém e além das teorias que constam nos documentos oficiais.

O próprio grupo dos internados está sujeito a toda uma série de fenômenos específicos, característicos de grupos de indivíduos institucionalizados. Um grupo monossexuado, grande ou pequeno, que vive em regime de internato, enclaustrado, tende a experimentar uma dinâmica de grupo própria: no processo de interação entre os membros desse grupo se produzem clãs, facções antagônicas, panelinhas, casais, lutas pelo poder, bodes expiatórios, delatores, vigilantes, hostilidades, agressividade etc. Portanto, no mundo dos internados, as decisões não são tomadas por indivíduos isolados considerados como liberdades independentes, nem a responsabilidade pode ser imputada apenas ao indivíduo. A dinâmica do grupo dos educandos, ao constituir-se, produz uma dimensão social e coletiva no contexto institucional formativo, os problemas de ordem 
formativa e pedagógica se coletivizam. O grupo dos internados, entregue a si mesmo, pode passar por uma série de etapas e experimentar diversos fenômenos que já exemplificamos longamente.

O grupo constituído pela equipe dirigente educadora também possui uma dinâmica própria: ele se encarrega de organizar burocraticamente a vida no estabelecimento, é o encarregado de tomar decisões, de controlar e usar o dinheiro, de organizar o tempo, de impor sua concepção pedagógica, que pode ser implícita, mais do que expressamente formalizada. $\mathrm{O}$ grupo dos formandos tende a aceitar essas funções da equipe de formadores, mesmo que sofra com isso, ao ter que se submeter a ela. Mas eles também oferecem uma resistência nem sempre velada à ação da equipe dirigente, que pode se explicitar em hostilidade e enfrentamentos abertos em momentos de agudização de conflitos.

Entre os dois grupos também existem fenômenos e relações determinadas, estabelece-se todo um jogo de forças, de estratégias de luta, dominação, conflito, vigilância e disputa, com resistências, acordos tácitos, concessões, confrontos eventuais, às vezes violentos ou mais sutis. Mas as relações de educação ou ressocialização tendem a ser predominantemente tensas, baseadas em estratégias e táticas de guerra, embora veladas, sobretudo quanto mais desconhecidas ou denegadas forem essas dinâmicas psicossociais. Esses fenômenos levam ao recrudescimento da equipe dirigente, que pode se tornar mais arbitrária e autoritária, irritada com os enfrentamentos que a utilização de práticas pedagógicas mais democráticas (no plano discursivo - tais com as assembleias e as consultas) permite aos educandos. Esses espaços de participação controlada podem ser utilizados para agredir e enfrentar a equipe de educadores, ou então para que estes endureçam com aqueles, causando aversão tanto nos educandos, quanto nos educadores e quanto ao uso de tais instrumentos pedagógicos.

Entendemos que trabalhar na superação do desconhecimento dos fenômenos específicos que se produzem no contexto institucional exige um processo de análise institucional e coloca-se como uma questão paradoxal para o profissional da Psicologia: esse pode ser 
facilmente recuperado pela autoridade burocrática que deseja ser mais flexível e aberta, ao promover uma formação "participativa" moderna, mas sem abrir mão do poder em momento algum. Ora, o ideal seria instituir um lugar de emergência da palavra social plena, organizando a educação de modo autogestivo, ou pelo menos cogestivo, integrando a ação de educadores e de educandos. Certamente, isso é pouco provável na conjuntura político-penal atual, de caráter fortemente concentrador de poder na autoridade. Mas essa contradição permanente constitui-se no pano de fundo de qualquer estratégia de intervenção num estabelecimento de internação dedicado ao processo de ressocialização. Podemos afirmar que a questão central do processo educativo, no contexto institucional, não se localiza no plano das técnicas pedagógicas, psicológicas ou assistenciais dos instrumentos formativos implementados, mas se concentra, sobretudo, nas relações de poder que organizam a ressocialização no estabelecimento.

A "encomenda estatal" que se faz para a Psicologia é que ela despolitize as contradições (sociais, de classe, institucionais, de poder) e as trate de modo psicologizado e sociologizado, por meio de abordagens focadas no indivíduo, escotomizando a realidade da produção histórica, social, coletiva e institucional da existência concreta.

A Psicologia como profissão, centrada no "modelo clínico tradicional", tem sofrido impactos positivos e críticos do pensamento dialético marxista, do institucionalismo e também do pensamento de Foucault, Deleuze e Guattari. A Psicologia é uma importante tecnologia social de produção de realidade social: ela não é apenas uma área do conhecimento científico ou um saber que busca fazer o "bem". Entendemos que a dimensão institucional deve ser problematizada pelo profissional psicólogo, para que ele não desenvolva uma intervenção ingênua, aparentemente benéfica, mas atendendo a encomenda institucional e desconhecendo a demanda.

Um trabalho que busca problematizar a Psicologia como ciência e profissão foi realizado por Ferreira Neto (2004). Também problematizamos a excessiva psicologização da vida contemporânea (Benelli, 2009), perguntando como se aceita com naturalidade - in- 
clusive solicitando-se com avidez - uma psicologização prescritiva da existência humana e a demanda crescente por sofisticação e desenvolvimento psicológico para pessoas normais. Noto a ausência de uma perspectiva ético-política crítica em alguns profissionais da Psicologia quando realizam seu trabalho visando à prevenção ou à promoção de saúde. Uma possibilidade para a compreensão de tais fenômenos está na hipótese da expansão da "cultura psicológica" proposta por Castel (1987). Aparentemente, a Psicologia como ciência humana parece estar superando a mera função de mistificar as contradições das relações sociais, dirigindo-se para uma prática mais ampla que visaria ao cultivo do relacional ou à expansão de uma cultura relacional.

Consideramos que é necessário analisar as diversas práticas institucionais (formativas, educativas, pedagógicas, terapêuticas, correcionais, socioeducativas), problematizando seus pressupostos subjacentes, procurando detectar como e até que ponto tais ações funcionam como filtros de transformação seletiva e deformante de qualquer proposta inovadora.

Trata-se mesmo de promover uma revolução conceitual: dependendo de como vemos determinado objeto, partimos da consideração de sua suposta natureza essencial para a produção de saberes e técnicas para trabalhá-lo. Os meios e os fins seriam então decorrentes dessa natureza presumida do objeto. É por isso que acreditamos na importância de uma análise das práticas, daquilo que fazemos no contexto institucional. O fazer embute em si uma teoria, um objeto, saberes e técnicas: produz subjetividade, modos de existência, sujeitos, universos de materialidade social. Tal processo pode se submeter ao sentido do processo hegemônico de produção de subjetividade, mas também pode orientar-se no sentido de produções singularizadas.

As coisas produzem o que elas podem, inclusive porque os indivíduos acreditam nelas e decidem aceitá-las, adotá-las e reproduzi-las tais como são e funcionam. Com a Psicologia isso também acontece. Produzir outros efeitos exige modificar os processos de produção que estão encarnados nas nossas práticas profissionais. 
Normalmente o psicólogo é chamado para resolver os problemas afetivos das pessoas. Ele seria alguém que poderia "dar um jeito" nos indivíduos problemáticos. Seus serviços psicoterapêuticos podem se tornar acréscimos quase luxuosos num determinado contexto institucional global. Não se espera, evidentemente, que esse profissional esteja ali para colaborar com os diversos agentes institucionais: ele deve apenas fazer psicoterapia individual. Esse é o papel clássico que se atribui ao psicólogo: como a subjetividade é reduzida à interioridade psíquica do indivíduo, a função desse profissional seria atuar numa clínica intersubjetiva e trabalhar na ortopedia da individualidade identitária. Tanto que é fácil se esquecer dele, não vê-lo, não notá-lo no estabelecimento, não avisá-lo de atividades que coincidam com seu dia e horários de atendimento. Isso indica sintomaticamente a relevância desse profissional no contexto institucional.

Uma interessante perspectiva teórico-técnica que parece levar em conta a intersecção psicologia-política, desejo e poder, é a da análise institucional, que se instrumentaliza com a noção de "subjetividade", buscando superar a dicotomia do subjetivo (que seria o plano do desejo, dimensão psicológica do indivíduo) "versus" a do objetivo (o plano político do poder) do contexto sociocultural. Analisando as relações de poder que permeiam e constituem as instituições, precisamos atentar para as brechas no instituído que possibilitam a elaboração de estratégias alternativas, buscar o aspecto instituinte, criativo, transformador das instituições, não visar a uma homeostase na sua repetitividade congelada. 


\section{REFERÊNCIAS}

AGUIAR, W. M. A pesquisa em Psicologia Sócio-Histórica. In: BOCK, A. M. B.; GONÇALVES, M. G. e FURTADO, O. (Org.). Psicologia Sócio-histórica: uma perspectiva crítica em psicologia. São Paulo: Cortez, 2002. p.129-40.

ALBUQUERQUE, J. A. G. Instituição e poder: a análise concreta das relações de poder nas instituições. Rio de Janeiro: Graal, 1980.

ALTOÉ, S. Infância perdida: o cotidiano nos internatos-prisão. Rio de Janeiro: Biblioteca Virtual de Ciências Humanas do Centro Edelstein de Pesquisas Sociais, 2008.

De "menor" a presidiário: a trajetória inevitável? Rio de Janeiro: Biblioteca Virtual de Ciências Humanas do Centro Edelstein de Pesquisas Sociais, 2009a.

Menores em tempo de maioridade: do internato-prisão à vida social. Rio de Janeiro: Biblioteca Virtual de Ciências Humanas do Centro Edelstein de Pesquisas Sociais, 2009b.

ALVES-MAZZOTTI, A. J.; GEWANDSZNAJDER, F. O método nas ciências naturais e sociais: pesquisa quantitativa e qualitativa. 2.ed. São Paulo: Pioneira, 1999.

ANTUNES, J. L. F. Hospital: instituição e história social. São Paulo: Letras e Letras, 1991.

ASSIS, M. B. A criança e a ordem: teoria e prática no tratamento da criança desviante na Belle Époque Carioca. São Paulo, 1997. Dissertação (Mestrado em História Social) - Faculdade de Filosofia, Letras e Ciências Humanas, Universidade de São Paulo. 
BAREMBLITT, G. F. Compêndio de análise institucional e outras correntes: teoria e prática. Rio de Janeiro: Record; Rosa dos Tempos, 1998.

BARROSO, T. P. B. Vida familiar e vida escolar: um estudo de caso sobre a trajetória escolar dos alunos internos do Centro Federal de Educação Tecnológica de Januária - MG. Rio de Janeiro, 2008. 61f. Dissertação (Mestrado em Educação Agrícola) - Instituto de Agronomia, Universidade Federal Rural do Rio de Janeiro.

BEHRING, E. R.; BOSCHETTI. Política social: fundamentos e história. São Paulo: Cortez, 2006. p.187-90.

BENELLI, S. J. O internato escolar como instituição total: violência e subjetividade. Psicologia em Estudo, Maringá, v.2, n.7, p.19-29, 2002.

Dispositivos disciplinares produtores de subjetividade na instituição total. Psicologia em Estudo, Maringá, v.2, n.8, p.99-114, 2003a.

Pescadores de homens: a produção da subjetividade no contexto institucional de um Seminário Católico. Assis, 2003b. Dissertação (Mestrado em Psicologia) - Faculdade de Ciências e Letras, Universidade Estadual Paulista "Júlio de Mesquita Filho".

. A instituição total como agência de produção de subjetividade na sociedade disciplinar. Estudos de Psicologia, Campinas, v.3, n.21, p.237-52, 2004a.

A formação eclesiástica. Fragmentos de Cultura, Universidade Católica de Goiás, v.10, n.14, p.1883-912, 2004b.

O internato escolar "O Ateneu": produção de subjetividade na instituição total. Revista de Psicologia, São Paulo, v.14, n.3, p.133-70, 2004c.

Pescadores de homens: estudo psicossocial de um seminário católico. São Paulo: Editora Unesp, 2006.

- A produção da subjetividade na formação contemporânea do clero católico. São Paulo, 2007. 486p. Tese (Doutorado em Psicologia Social) - Instituto de Psicologia, Universidade de São Paulo.

A cultura psicológica no mercado de bens de saúde mental contemporâneo. Estudos de Psicologia, Campinas, v.26, n.4, p.515-36, 2009.

. Cartografia das instituições de Assistência Social a crianças e adolescentes num município do interior do Estado de São Paulo. Assis, 2010. Tese (Pós-doutorado) - Faculdade de Ciências e Letras, Unesp.

BENELLI, S. J.; COSTA-ROSA, A. A produção da subjetividade no contexto institucional de um seminário católico. Estudos de Psicologia, v.2, n.19, p.37-58, 2002. 
Geografia do poder em Goffman: vigilância e resistência, dominação e produção de subjetividade no hospital psiquiátrico. Estudos de Psicologia, Campinas, v.20, n.2, p.35-49, 2003a.

Estudo sobre a formação presbiteral num seminário católico. Estudos de Psicologia, Campinas, v.20, n.3, p.99-123, 2003b.

Movimentos religiosos totalitários católicos: efeitos em termos de produção de subjetividade. Estudos de Psicologia, Campinas, v.23, n.4, p.339-58, 2006.

Para uma crítica da razão socioeducativa em entidades assistenciais. Estudos de Psicologia, Campinas, v.28, n.4, p.539-63, 2011.

BLAZQUEZ, R. Las comunidades Neocatecumenales: discernimiento teologico. Bilbao: Desclee de Brouwer, 1996.

BRASIL. Presidência da República. Estatuto da Criança e do Adolescente: ECA - Lei 8.069, de 13 de julho de 1990. Brasília, 1990.

BRIGHENTI, A. A Igreja do futuro e o futuro da Igreja: perspectivas para a evangelização na aurora do terceiro milênio. São Paulo: Paulus, 2001.

CABRAS, A. Os anjos querem ser homens - um estudo sobre a laicização de padres no Brasil. São Paulo, 1982. Dissertação (Mestrado em Ciências Sociais) - Faculdade de Filosofia, Letras e Ciências Humanas, Universidade de São Paulo.

CASTEL, R. A ordem psiquiátrica: a idade de ouro do alienismo. Rio de Janeiro: Graal, 1978.

A gestão dos riscos: da antipsiquiatria à pós-psicanálise. Rio de Janeiro: Francisco Alves, 1987.

CÉSAR, M. R. A. A invenção da adolescência no discurso psicopedagógico. São Paulo: Editora Unesp, 2008.

COMBLIN, J. O Cristianismo no limiar do terceiro milênio. In: CALIMAN, C. (Org.) A sedução do sagrado: o fenômeno religioso na virada do milênio. 2.ed. Petrópolis: Vozes, 1999. p.143-60.

O povo de Deus. 2.ed. São Paulo: Paulus, 2002.

CONSELHO FEDERAL DA ORDEM DOS ADVOGADOS DO BRASIL, Conselho Federal de Psicologia, Conselhos Regionais de Psicologia. Direitos humanos: um retrato das unidades de internação dos adolescentes em conflito com a lei. Brasília: OAB, CFP, 2006.

CONSELHO FEDERAL DE PSICOLOGIA. Falando sério sobre prisões, prevenção e segurança pública: proposta do Conselho Federal de Psicologia para o enfrentamento da crise do sistema prisional. Brasília: CFP, 2008.

Atuação do psicólogo no sistema prisional. Brasília: CFP, 2010a. 
- Referências técnicas para atuação de psicólogos no âmbito das medidas socioeducativas em unidades de internação. Brasília: CFP, $2010 \mathrm{~b}$.

CORDONNIER, G. Nascer de novo: os novos cristãos pelo caminho do catecumenado. Coimbra: Secretariado Nacional da Educação Cristã, 1995.

COSTA-ROSA, A. Saúde mental comunitária: análise dialética de um movimento alternativo. São Paulo, 1987. Dissertação (Mestrado em Psicologia Social) - Instituto de Psicologia, Universidade de São Paulo.

Práticas de cura nas religiões e tratamento psíquico em saúde coletiva. São Paulo, 1995. 192p. Tese (Doutorado em Psicologia) - Instituto de Psicologia, Universidade de São Paulo.

O Modo Psicossocial: um paradigma das práticas substitutivas ao modo asilar. In: AMARANTE, P. D. C. (Org.) Ensaios de loucura $\mathcal{E}$ civilização. Rio de Janeiro: Fiocruz, 2000. v.1, p.41-168.

A Instituição de Saúde Mental como dispositivo de produção de subjetividade. Assis: Unesp, 2006. (Mimeog.)

COSTA-ROSA, A. et al. Atenção Psicossocial: rumo a um novo paradigma em saúde mental coletiva. In: AMARANTE, P. (Org.) Archivos de Saúde Mental e Atenção Psicossocial. Rio de Janeiro: Ed. Nau, 2003. p.13-44.

CRUZ, S. G. F. P. Herói ou bandido? Um estudo sobre a produção de identidade em policiais militares. São Paulo, 1989. Dissertação (Mestrado em Psicologia Social) - Faculdade de Psicologia, Pontifícia Universidade Católica.

DELEUZE, G. Post-scriptum sobre as sociedades de controle. In: Conversações. São Paulo: Editora 34, 1992. p.219-26.

DONZELOT, J. A polícia das famílias. 3.ed. Rio de Janeiro: Graal, 2001.

DOR, J. Estrutura e perversões. Porto Alegre: Artes Médicas, 1991.

DREYFUS, H.; RABINOW, P. Michel Foucault, uma trajetória filosófica: para além do estruturalismo e da hermenêutica. Rio de Janeiro: Forense, 1995.

FERNANDEZ, P. La celebracion de la eucaristia en el camino neocatecumenal. Revista Phase, v.44, n.260, p.139-65, 2004.

FERRAZ E FERRAZ, M. G. C. Religare. Uma cartografia da fé. São Paulo, 1994. 2v. Tese (Doutorado em Psicologia Clínica) - Faculdade de Psicologia, Pontifícia Universidade Católica.

FERREIRA, D. F.; LAUAND, M.; SILVA, M. F. Opus Dei: os bastidores, história, análise, testemunhos. Campinas: Verus, 2005. 
FERREIRA, M. S. Polissemia do conceito de instituição: diálogos entre Goffman e Foucault. ECOS - Estudos Contemporâneos da Subjetividade, v.2, n.1, p.74-86, 2012.

FERREIRA NETO, J. L. A formação do psicólogo. Clínica, social e mercado. São Paulo: Escuta, 2004.

FIGUEIREDO, G. R. A evolução do hospício no Brasil. São Paulo, 1996. 238p. Tese (Doutorado) - Escola Paulista de Medicina, Universidade de São Paulo.

FONDI, E.; ZANZUCCHI, M. Um povo nascido do Evangelho: Chiara e os focolares. São Paulo: Paulus, 2004.

FOUCAULT, M. O nascimento da clínica. Rio de Janeiro: Graal, 1977. A verdade e as formas jurídicas. Rio de Janeiro: PUC, 1984. O cuidado de si. Rio de Janeiro: Graal, 1985. A vontade de saber. Rio de Janeiro: Graal, 1988. O sujeito e o poder. In: DREYFUS, H.; RABINOW, P. Michel Foucault, uma trajetória filosófica: para além do estruturalismo e da hermenêutica. Rio de Janeiro: Forense, 1995. p.231-49. 1999a.

História da loucura na idade clássica. São Paulo: Perspectiva, . Vigiar e punir: nascimento da prisão. Petrópolis: Vozes, 1999b.

FRANÇA, S. A. M. Diálogos com as práticas de saúde mental desenvolvidas na rede de saúde pública. São Paulo, 1994. 146p. Tese (Doutorado em Psicologia Clínica) - Faculdade de Psicologia, Pontifícia Universidade Católica.

FREITAG, B. O indivíduo em formação: diálogos interdisciplinares sobre educação. São Paulo: Cortez, 2001.

FREUD, S. Psicología de las masas e análisis del "Yo". Madrid: Biblioteca Nueva, s. d.(a). t.III, p.2563-610 [1921].

. El porvenir de una ilusión. Madrid: Biblioteca Nueva, s. d.(b). t.III, p.2961-92 [1927].

. La negación. Madrid: Biblioteca Nueva, s. d.(c). t.III, p.2884-6 [1925].

Nuevas lecciones introductorias al Psicoanálisis. Lección XXXV: El Problema de la Concepción del Universo (Weltanschauung). Madrid: Biblioteca Nueva, s d.(c) t.III, p.3191-206 [1932]. v.XXI.

O mal-estar na civilização. E.S.B. Rio de Janeiro: Imago, 1930.

GALINDO F. O fenômeno das seitas fundamentalistas. Petrópolis: Vozes, 1994. 
GOFFMAN, E. Manicômios, prisões e conventos. São Paulo: Perspectiva, 1987.

GOMES DA COSTA, A. C. Os Regimes de Atendimento no Estatuto da Criança e do Adolescente: perspectivas e desafios. Brasília: Secretaria Especial dos Direitos Humanos, 2006a.

Socioeducação: estrutura e funcionamento da comunidade educativa. Brasília: Secretaria Especial dos Direitos Humanos, 2006b.

GOYOMARD, P. O gozo do trágico: Antígona, Lacan e o desejo do analista. Rio de Janeiro: Zahar, 1996.

GUATTARI, F.; ROLNIK, S. Micropolítica: cartografias do desejo. Petrópolis: Vozes, 1986.

GUIMARÃES, A. M. Vigilância, punição e depredação escolar. Campinas: Papirus, 1985.

GUIRADO, M. Instituição e relações afetivas: o vínculo com o abandono. São Paulo: Summus, 1986.

Psicologia institucional. São Paulo: EPU, 1987.

HESSE, H. Narciso e Goldmund. São Paulo: Brasiliense, 1970.

Menino prodígio. Rio de Janeiro: Record, 1980.

JORGE, M. A. C. Discurso médico e discurso psicanalítico. In: CLAVREUL, J. A ordem médica: poder e impotência do discurso médico. São Paulo: Brasiliense, 1983. p.164-76.

KOERNER, A. Punição, disciplina e pensamento penal no Brasil do século XIX. Lua Nova, São Paulo, v.68, p.205-42, 2006.

LACAN, J. O mito individual do neurótico. Lisboa: Assírio e Alvim Cooperativa Editora e Livreira, Scarl, 1980.

O Seminário - Livro 2: O eu na teoria de Freud e na técnica da Psicanálise. Rio de Janeiro: Jorge Zahar, 1997.

A Agressividade em psicanálise. In: Escritos. Rio de Janeiro: Jorge Zahar, 1998. p.104-26.

LAPIERRE, J.-P. Regras dos monges: Pacômio, Agostinho, Bento, Francisco, Carmelo. São Paulo: Paulinas, 1993.

LAPLANCHE, J.; PONTALIS, J.-B. Vocabulário da Psicanálise. São Paulo: Martins Fontes, 1996.

LASCH, C. A cultura do Narcisismo. Rio de Janeiro: Imago, 1983.

LAUTRÉAMONT, C. Cantos de Maldoror. São Paulo: Max Limonad, 1986.

LE TOURNEAU, D. O Opus Dei. Lisboa: Rei dos Livros, 1985.

LEVINSON, D. J.; GALLAGHER, E. B. Sociología del enfermo mental. Buenos Aries: Amorrortu, 1971. 
LIBÂNIO, J. B. A volta à grande disciplina. São Paulo: Loyola, 1984. . Igreja contemporânea. Encontro com a modernidade. São Paulo: Loyola, 2000.

Olhando para o futuro: prospectivas teológicas e pastorais do Cristianismo na América Latina. São Paulo: Loyola, 2003.

Impactos da realidade sociocultural e religiosa sobre a vida consagrada a partir da América Latina. Busca de respostas. Perspectiva Teológica, v.37, p.55-88, 2005.

LIMA, R. O fanatismo religioso entre outros. Revista Espaço Acadêmico, v.17, 2002. Disponível em: <http://www.espaçoacademico.com. br/017/17ray.htm>. Acesso em: 4 jul. 2004.

LINDHOLM, C. Carisma. Rio de Janeiro: Zahar, 1993.

LOSICER, E. Evocar Lourau. In: RODRIGUES, H. B. C.; ALTOÉ, S. (Org.). Análise institucional. SaúdeLoucura 8. São Paulo: Hucitec, 2004. p.101-14.

LOURAU, R. A análise institucional. Petrópolis: Vozes, 1995.

LUBICH, C. Ideal e luz: pensamento, espiritualidade, mundo unido. São Paulo: Brasiliense; Cidade Nova, 2003.

MARCÍLIO, M. L. O menor infrator e os direitos da criança no século XX. In: LOURENÇO, M. C. F. (Org.). Direitos Humanos em dissertações e teses da USP: 1954-1999. São Paulo: Editora Universidade de São Paulo, 2000. p.39-49.

História social da criança abandonada. São Paulo: Hucitec, 2006.

MARTELLI, S. A religião na sociedade pós-moderna: entre secularização e dessecularização. São Paulo: Paulinas, 1995.

MONTEIRO, R. C.; GONÇALVES, S. M. M. (Org.). Internato na formação agrícola. Seropédica: Edur, 2012.

MORAIS, N. A. et al. Notas sobre a experiência de vida num internato: aspectos positivos e negativos para o desenvolvimento dos internos. Psicologia em Estudo, Maringá, v.9, n.3, p.379-87, 2004.

MORANO, C. D. Crer depois de Freud. São Paulo: Loyola, 2003.

MUSIL, R. O jovem Törless. Rio de Janeiro: Rio Gráfica, 1986.

NEVES, T. A defesa institucional numa instituição total: o caso de um centro de internamento de menores delinquentes. Revista Análise Social, Lisboa, v.XLII, n.185, p.1021-39, 2007.

NICÁCIO, F. O processo de transformação da saúde mental em Santos: desconstrução de saberes, instituições e cultura. São Paulo, 1994. 193p. Dissertação (Mestrado em Ciências Sociais) - Faculdade de Ciências Sociais, Pontifícia Universidade Católica. 
NUNES, A. C. Sociedade e poder no "Ateneu" de Raul Pompéia. Revista do Instituto de Filosofia e Ciências Humanas - UFRGS, Porto Alegre, v.8, p.221-231, 1986.

OLIVEIRA, L. E. Jesus abandonado em Chiara Lubich: uma perspectiva para a inculturação do evangelho. Porto Alegre, 1988. Dissertação (Mestrado em Teologia Sistemática) - Faculdade de Teologia, Pontifícia Universidade Católica.

PAIXÃO, A. L. Recuperar ou punir: como o Estado trata o criminoso. São Paulo: Cortez, 1991.

PASOTTI, E. (Org.). O caminho Neocatecumenal segundo Paulo VI e João Paulo II. São Paulo: Loyola, 1999.

PELLEGRINO, H. Pacto edípico e pacto social. In: PY, L. A. et al. Grupo sobre grupo. Rio de Janeiro: Rocco, 1987. p.195-205.

PEREIRA, W. C. C. A formação religiosa em questão. Petrópolis: Vozes, 2004.

PEREZ, G. R. El Opus Dei: una explicación. Madrid: Railp, 1992.

PERRONE-MOISÉS, L. (Org.) O Ateneu: retórica e paixão. São Paulo: Brasiliense; Edusp, 1988.

PETOT, J. M. Melanie Klein. São Paulo: Perspectiva, 1991. 2v.

PIRES, M. A. A questão do internato nas escolas técnicas de Agricultura e pecuária em São Paulo - o caso do Centro Estadual de Educação Tecnológica "Paula Souza" - CEETEPS. Piracicaba, 2005. 189f. Dissertação (Mestrado em Educação) - Faculdade de Educação, Universidade Metodista de Piracicaba.

POLETTO, L. B. Institucionalização de crianças e adolescentes em Caxias do Sul: narrativas sobre as trajetórias de vida de egressos de medida de proteção (1990-2011). Caxias do Sul, 2013. Dissertação (Mestrado em Educação) - Faculdade de Educação, Universidade de Caxias do Sul.

POMPÉIA, R. O Ateneu. São Paulo: PubliFolha, 1997.

PRADA, A. V. O fundador do Opus Dei: Mons. Josemaria Escriva de Balaguer 1902-1975. São Paulo: Quadrante, 1989.

QUEIRUGA, A. T. Do terror de Isaac ao Abbá de Jesus: por uma nova imagem de Deus. São Paulo: Paulinas, 2001.

. Fim do cristianismo pré-moderno: desafios para um novo horizonte. São Paulo: Paulus, 2003.

REGO, J. L. do. Doidinho. 18.ed Rio de Janeiro: José Olympio, 1979. Menino de engenho. 31.ed. Rio de Janeiro: José Olympio, 1982.

REY, F. G. La investigación cualitativa em Psicología: rumbos y desafíos. São Paulo: Educ, 1999. 
RIZZINI, I. O século perdido: raízes históricas das políticas públicas para a infância no Brasil. São Paulo: Cortez, 2008.

O cidadão polido e o selvagem bruto: a educação dos meninos desvalidos na Amazônia Imperial. Rio de Janeiro, 2004. Tese (Doutorado em História) - Instituto de Filosofia e Ciências Sociais, Universidade Federal do Rio de Janeiro.

RIZZINI, I.; PILOTTI, F. (Org.). A arte de governar crianças. São Paulo: Cortez, 2009.

ROCHA, C. L. R. "Muitos são os chamados mas poucos escolhidos" um estudo sobre a vocação sacerdotal. Campinas, 1991. Dissertação (Mestrado em Antropologia Social) - Instituto de Filosofia, Letras e Ciências Humanas, Universidade Estadual de Campinas.

RODRIGUEZ, P. et al. O Opus Dei na Igreja: introdução eclesiológica à vida e ao apostolado do Opus Dei. (Magistra, n.6). Lisboa: Rei dos Livros, 1993.

RONDONI, D. (Org.). Comunhão e libertação: um movimento na Igreja. São Paulo: Sociedade Litterae Communionis, 1999.

ROMAN, M. D. Psicologia e adolescência encarcerada: a dimensão educativa em meio à barbárie. São Paulo, 2007. 285p. Tese (Doutorado em Psicologia) - Instituto de Psicologia, Universidade de São Paulo.

ROTELLI, F. et al. Desinstitucionalização, uma outra via. In: NICÁCIO, F. (Org.). Desinstitucionalização. São Paulo: Hucitec, 1990. p.17-59.

SALLA, F. A retomada do encarceramento: as masmorras high-tech e a atualidade do pensamento de Michel Foucault. In: BIROLI, F.; ALVAREZ, M. C. (Org.). Michel Foucault: histórias e destinos de um pensamento. Marília: Unesp Publicações, 2000. p.35-58. (Cadernos da F.F.C. - Unesp).

SALIBA, M. G. O olho do poder: análise crítica da proposta educativa do Estatuto da Criança e do Adolescente. São Paulo: Editora Unesp, 2006.

SCHUNEMANN, H. E. S. Internatos adventistas: a transposição de um modelo estadunidense de educação. In: SIMPÓSIO NACIONAL DO CEHILA - Modernidade, Instituições e Historiografia Religiosa no Brasil, Mariana, MG, Brasil, 2008. Disponível em: <www. ichs.ufop.br/ner/images/stories/Haller_Elinar_Stach_Schunemann. pdf>. Acesso: 20 out. 2010.

SILVA, D. N. Trajetórias no contexto de um internato: das expectativas familiares às experiências dos internos e egressos. Salvador, 2007. 201f. 
Dissertação (Mestrado em Família na Sociedade Contemporânea) Universidade Católica de Salvador.

SILVA, D. N.; RABINOVICH, E. P. Expectativas parentais: o internato como contexto de desenvolvimento. Revista Brasileira Crescimento e Desenvolvimento Humano, v.17, n.3, p.60-71, 2007.

SILVA, R. A. S. L. Igreja comunhão e movimento dos focolares: a eclesiologia de comunhão como centro da espiritualidade e vida do movimento dos focolares. Porto Alegre, 2000. Dissertação (Mestrado em Teologia Sistemática) - Faculdade de Teologia, Pontifícia Universidade Católica.

SZASZ, T. O mito da doença mental. Rio de Janeiro: Zahar, 1979.

TAGLIAVINI, J. V. Garotos no túnel - um estudo sobre a imposição da vocação sacerdotal e o processo de condicionamento nos seminários. Campinas, 1990. Dissertação (Mestrado em Ciências Sociais) - Instituto de Filosofia, Letras e Ciências Humanas, Universidade Estadual de Campinas.

TREVISAN, J. S. Em nome do desejo. 2.ed. São Paulo: Max Limonad, 1985.

URQUHART, G. A armada do Papa: os segredos e o poder nas novas seitas da Igreja Católica. Rio de Janeiro: Record, 2002.

VICENTE, A. F. O caminho Neocatecumenal: um caminho de iniciação cristã. Porto: Perpetuo Socorro, 1988. (Comunidade Viva, n.17).

YASUI, S. A construção da reforma psiquiátrica e seu contexto histórico. Assis, 1999. 248p. Dissertação (Mestrado em Psicologia) - Faculdade de Ciências e Letras, Universidade Estadual Paulista "Júlio de Mesquita Filho".

ZANCHIN, C. R. Os diversos olhares na construção das medidas socioeducativas no município de São Carlos/SP. São Paulo, 2010. 80f. Dissertação (Mestrado em Serviço Social) - Programa de Pós-Graduação em Serviço Social, Pontifícia Universidade Católica. 
SOBRE O LIVRO

Formato: $14 \times 21 \mathrm{~cm}$

Mancha: 23,7 x 42,5 paicas

Tipologia: Horley Old Style 10,5/14

Papel: Off-set $75 \mathrm{~g} / \mathrm{m}^{2}$ (miolo)

Cartão Supremo $250 \mathrm{~g} / \mathrm{m}^{2}$ (capa)

1a edição: 2014

EQUIPE DE REALIZAÇÃO

Coordenação Geral

Marcos Keith Takahashi 
A tecnologia social da internação é bastante antiga e, apesar de toda a crítica sólida já apresentada, de modo surpreendente, continua sendo uma ferramenta bastante utilizada na atualidade. Apesar de sua evidente superação teórica, técnica, política e ética, a internação ainda é largamente empregada em diferentes áreas: na educação escolar (escolas confessionais, colégios agrícolas), na formação do clero católico (seminários), na formação de religiosos e religiosas (casas de formação), na saúde (hospital geral), na psiquiatria (manicômios), na socioeducação (unidades de privação de liberdade para adolescentes que cometeram atos infracionais), na Assistência Social (casas de acolhimento institucional variadas), na segurança pública (presídios), no exército (quartéis), dentre outros.

Dada sua persistência no campo social, é importante conhecer sua estrutura, lógica de funcionamento bem como os efeitos que podem produzir. É isso que é apresentado nesse livro, por meio das categorias de instituição total e disciplinar.

Silvio José Benelli é professor da Faculdade de Ciências e Letras (FCL) da Universidade Estadual Paulista "Júlio de Mesquita Filho" (Unesp), campus de Assis. É licenciado (1990) em Filosofia pela Faculdade Salesiana de FCL de Lorena, psicólogo (200I) e mestre (2003) em Psicologia pela FCL da Unesp, campus de Assis. É doutor (2007) em Psicologia Social pelo Instituto de Psicologia da USP.É autor dos livros Pescadores de homens (2006), Análise psicossocial da formação do clero católico (2013) e Entidades assistenciais socioeducativas (2014). 